\title{
Lyme borreliosis in the Netherlands : epidemiological and laboratory aspects
}

Citation for published version (APA):

Nohlmans-Paulssen, M. K. E. (1995). Lyme borreliosis in the Netherlands : epidemiological and laboratory aspects. [Doctoral Thesis, Maastricht University]. Rijksuniversiteit Limburg. https://doi.org/10.26481/dis.19950428mn

Document status and date:

Published: 01/01/1995

DOI:

10.26481/dis.19950428mn

Document Version:

Publisher's PDF, also known as Version of record

\section{Please check the document version of this publication:}

- A submitted manuscript is the version of the article upon submission and before peer-review. There can be important differences between the submitted version and the official published version of record.

People interested in the research are advised to contact the author for the final version of the publication, or visit the DOI to the publisher's website.

- The final author version and the galley proof are versions of the publication after peer review.

- The final published version features the final layout of the paper including the volume, issue and page numbers.

Link to publication

\footnotetext{
General rights rights.

- You may freely distribute the URL identifying the publication in the public portal. please follow below link for the End User Agreement:

www.umlib.nl/taverne-license

Take down policy

If you believe that this document breaches copyright please contact us at:

repository@maastrichtuniversity.nl

providing details and we will investigate your claim.
}

Copyright and moral rights for the publications made accessible in the public portal are retained by the authors and/or other copyright owners and it is a condition of accessing publications that users recognise and abide by the legal requirements associated with these

- Users may download and print one copy of any publication from the public portal for the purpose of private study or research.

- You may not further distribute the material or use it for any profit-making activity or commercial gain

If the publication is distributed under the terms of Article $25 \mathrm{fa}$ of the Dutch Copyright Act, indicated by the "Taverne" license above, 


\section{Lyme Borreliosis in The Netherlands}

Epidemiological and Laboratory Aspects 
$\overline{0.070}$ 


\title{
Lyme Borreliosis in The Netherlands Epidemiological and Laboratory Aspects
}

\section{PROEFSCHRIFT}

\author{
ter verkrijging van de graad van doctor \\ aan de Rijksuniversiteit Limburg te Maastricht, \\ op gezag van de Rector Magnificus, \\ Prof. Mr. M.J. Cohen, \\ volgens het besluit van het College van Dekanen, \\ in het openbaar te verdedigen op \\ vrijdag 28 april 1995 \\ om 14.00 uur
}

door 


\section{Promotores:}

Prof.dr. C.P.A. van Boven (Rijksuniversiteit Leiden)

Prof.dr. J.A.A. Hoogkamp-Korstanje (Katholieke Universiteit Nijmegen)

\section{Co-promotor:}

Drs. A.E.J.M. van den Bogaard

\section{Beoordelingscommissie:}

Prof.dr. J.M.J.P. van der Linden (Voorzitter)

Prof.dr. R. van Furth (Rijksuniversiteit Leiden)

Prof.dr. P.G. Knipschild

Prof.dr. H.A.M. Neumann

Prof.dr. J. Troost

This thesis was financially supported by grants

from the national "Rheuma-fonds", the national "Praeventiefonds"

and the Dutch Veterinary Public Health Inspectorate. 
Ter nagedachtenis aan mijn moeder aan Jan 


\section{CIP-DATA KONINKLIJKE BIBLIOTHEEK, DEN HAAG}

Nohlmans-Paulssen, Maria Katharina Elisabeth

Lyme Borreliosis in The Netherlands : epidemiological and laboratory aspects / Maria Katharina Elisabeth Nohlmans-Paulssen. - [S.I. : s.n.] (Arnhem : Foto Michel Wijn). - III.

Thesis Rijksuniversiteit Limburg Maastricht. - With ref. With summary in Dutch.

I.S.B.N. $90-801844-3-8$

NUGI $742 / 743$

Subject headings: Lyme borreliosis / epidemiology ; The Netherlands.

(C) 1995 MKE Nohlmans-Paulssen

Alle rechten voorbehouden. Niets uit deze uitgave mag worden verveelvoudigd, opgeslagen in een geautomatiseerd gegevensbestand, of openbaar gemaakt in enige vorm of op enige wijze, hetzij electronisch, mechanisch, door fotokopieën, opnamen, of op enige andere manier, zonder voorafgaande schriftelijke toestemming van de auteur.
All rights reserved. No part of this publication may be reproduced, stored in a retrieval system, or transmitted in any form or by any means, electronic, mechanical, photocopying, recording or otherwise, without the prior written permission from the author.

Lay-out: Foto MICHEL WIJN vof, Arnhem

Printing: DRUKKERIJ ARNHEM, Arnhem, The Netherlands 
"In previous years, sudden increases in diagnostic labels not otherwise justified by epidemiological evidence have included hypoglycemia, total allergy syndrome, and chronic Epstein Barr virus infection. Today it is Lyme disease."

Robert A. Aronowitz 


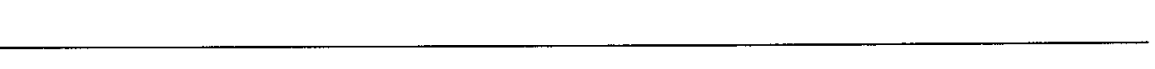




\section{CONTENTS}

Chapter 1

General review and aim of the study.

Chapter 2

Isolation and cultivation of Borrelia burgdorferi.

\section{Chapter 3}

Occurrence of Borrelia burgdorferi in Ixodes ricinus

in The Netherlands.

Chapter 4

Genotypic and phenotypic analysis of Borrelia burgdorferi isolates from The Netherlands.

Chapter 5

Evaluation of nine serological tests for diagnosis of Lyme borreliosis.

Chapter 6

Validity of Western immunoblot as a serodiagnostic tool

for Lyme borreliosis.

Chapter 7

Prevalence of Lyme borreliosis in The Netherlands.

Summary

Samenvatting

Dankwoord

Curriculum vitae 
10 
1

GENERAL REVIEW AND AIM OF THE STUDY 


\section{GENERAL REVIEW AND AIM OF THE STUDY}

\section{HISTORICAL NOTES}

The aetiological agent of Lyme borreliosis was first isolated in the USA only about fifteen years ago, although the early skin disorder and the neurological manifestations of the disease had already been described in Europe at the beginning of this century.

In 1909, the Swedish dermatologist Afzelius, reported a patient with a ringlike lesion that slowly migrated by expanding its peripheral borders while being accompanied by central clearing (1). This lesion was thought to have developed as a result of a bite of the sheep tick Ixodes ricinus and was referred to as erythema chronicum migrans (2).

The first evidence of nervous system involvement associated with erythema migrans was reported in 1922 by the French neurologists Garin and Bujadoux (3). They reported a painful meningoradiculitis after the bite of a tick. Bannwarth from Germany described a similar syndrome which, in some cases, was preceded by erythema migrans (4). The cause of erythema migrans was unknown until 1948, when Lennhoff from Sweden claimed to have developed a staining technique that permitted him to demonstrate spirochetes in biopsy specimens taken from various skin lesions including erythema migrans and lymphadenosis benigna cutis (5). Lennhoff's staining technique based on mercury chloride interaction with spirochetes, did not find wide approval because tissue fibres, fungi and other microorganisms were also stained. The first indisputable evidence that erythema migrans is caused by an infectious agent susceptible to antibiotics was proved by Binder et al. (6) in 1955. These authors transplanted biopsies taken from a patient with erythema migrans into three volunteers. Within one to three weeks all three volunteers developed typical erythema migrans lesions. Treatment with penicillin led to the disappearance of the lesions within a few days.

In the USA, the first case of erythema migrans was reported by Scrimenti in 1970 (7). Five years later two women from Lyme, Connecticut, who did not accept the medical diagnosis of juvenile rheumatoid arthritis in some of their own and their neighbours' children, made known their doubts to the State Health Department. A subsequent retrospective study by Steere et al. (8) revealed that, between 1972 and 1977, 51 cases of "Lyme arthritis" had occurred in the heavily wooded contiguous communities of Lyme, Old Lyme and East Haddam. These 51 cases, in a total population of 12,000 inhabitants, represented more than 100 times the expected incidence of juvenile rheumatoid arthritis in a population of this size. In their report, Steere et al. (8) noticed that the annual peak incidence of "Lyme arthritis" was in the summer and early autumn. Twenty-five percent of the patients had suffered from a distinct, expanding, red annular skin lesion before the onset of arthritis fitting the description of erythema migrans. The rural setting of the case 
clusters, identification of erythema migrans as a feature of the illness, favourable response of erythema migrans to penicillin, and the fact that serological investigations failed to confirm a viral or rickettsial aetiology, led to the working hypothesis of a bacterial infection transmitted by ticks. However, it was not until 1981 that Willy Burgdorfer of the Rocky Mountain Laboratories of the National Institute of Allergy and Infectious Diseases, discovered the causative agent of the disease (9). At that time Burgdorfer was carrying out a survey on Rickettsia rickettsii, the causative agent of Rocky Mountain spotted fever, in Ixodes scapularis ticks (until recently: Ixodes dammini) from Long Island, New York, and unexpectedly found these ticks to harbour spirochetes rather than rickettsiae. The first indication that these spirochetes were the causative agent of what is now called Lyme disease or Lyme borreliosis was obtained by immunofluorescent antibody assay with sera of affected patients. Spirochetes in midgut smears of infected ticks served as antigens. Soon afterwards, Barbour succeeded in isolating the organism from ticks, skin biopsies, blood and cerebrospinal fluid from patients with Lyme borreliosis (10). In 1984 Johnson et al. (11) reported the organism to be a new species belonging to the genus Borrelia, which in honour of its discoverer was named Borrelia burgdorferi. B. burgdorferi was also recovered in Europe from ticks, and from patients with Lyme borreliosis (12-14).

\section{BORRELIA BURGDORFERI}

Borrelia burgdorferi belongs to the eubacterial order Spirochaetales. In common with other spirochetes the organism has the following structural characteristics: 1 ) the cells are helically shaped and motile 2) an outer cell membrane surrounds the protoplasmic cylinder complex, consisting of the cytoplasm, the inner cell membrane and the peptidoglycan 3) flagella are not located at the cell's surface but in the periplasmic space between the

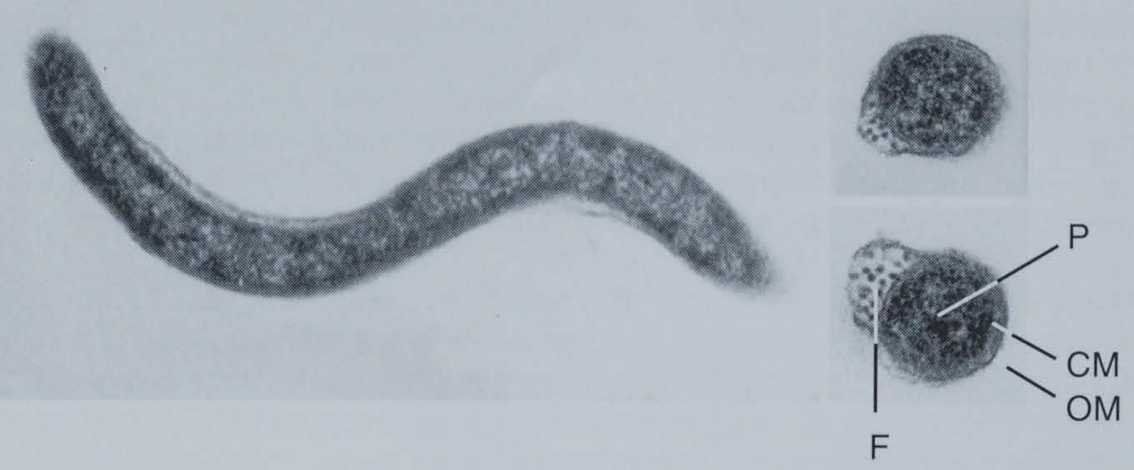

Figure 1. Electron photomicrograph of a thin section of Borrelia burgdorferi B31 cells. P, protoplasmic cylinder complex; $\mathrm{CM}$, cytoplasmic membrane; $\mathrm{F}$, flagella; OM, outer membrane. 
outer membrane and the protoplasmic cylinder. These flagella are inserted at the termini of the protoplasmic cylinder (Figure 1) (15). B. burgdorferi is a micro-aerophilic, gram-negative organism. The spirochete is 10 to $30 \mu \mathrm{m}$ long, 0.20 to $0.30 \mu \mathrm{m}$ wide and composed of 3-10 loose coils. It has tapered ends. At each end 7 to 11 flagella are inserted. The corkscrew-like movements of the spirochete can easily be detected by dark-field or phase-contrast microscopy, but visualization of the organism by light-microscopy after staining with Gram's or Giemsa's stain, or carbol fuchsin is also possible (15-18). Under unfavourable conditions such as in ageing cultures or antibiotic containing cultures, minute granular forms and forms with terminal or central bleb-like structures can be observed $(15,19)$. There are indications that these structures contain DNA but their viability and their exact nature have not yet been determined $(15,18)$. For the in-vitro cultivation of $B$. burgdorferi complex culture media similar to that used for tissue cultures are needed. The liquid BSKII (Barbour-Kelly-Stoenner) medium or one of its modifications are most commonly used (20). The optimal temperature for multiplication is $30^{\circ} \mathrm{C}$ to $34^{\circ} \mathrm{C}$. At temperatures of $40^{\circ} \mathrm{C}$ and above the spirochete loses its viability $(20)$. However, at $4^{\circ} \mathrm{C} B$. burgdorferi may remain viable for months. Depending on the medium and the culture conditions used, the generation time of $B$. burgdorferi varies between 12 to 24 hours. After 10 to 15 in-vitro passages the spirochete loses pathogenesis as determined in laboratory animals (15). Culture adapted strains freely swim in the medium and cell concentration of $10 \% / \mathrm{ml}$ may be obtained. Freshly isolated strains tend to grow in large aggregates, which may be macroscopically visible on the bottom of the culture tubes (20). Following dispersion of these clumps by vortexing they rapidly reassemble. Barbour (20) has suggested that the "stickiness" of early passages may reflect important in-vivo phenomena such as tissue binding and resistance to phagocytosis. Cultivation of $B$. burgdorferi on solid media is difficult. Only in two studies the spirochete was shown to grow in single colonies on a modified BSKII medium $(21,22)$.

Little is known about the biochemical characteristics of $B$. burgdorferi . As a member of the genus Borrelia, the spirochete produces lactic acid as the main end product of fermentation. This characteristic separates the genus Borrelia from spirochetes belonging to the genera Treponema and Leptospira (18). The commercial enzyme system APIZYM (Api Systems, France) has been employed to detect interspecies differences in the genus Borrelia as well as separating it from Treponema on the basis of leucine aminopeptidase, $\beta$-galactosidase, and $\alpha$-glucosidase, but identification to the species level is not possible (18).

Molecular analysis of $B$. burgdorferi has mainly been focused on proteinaceous compounds. Whole-cell lysates reveal more than 30 polypeptides in sodium dodecyl-sulphate (SDS) polyacrylamide gel electrophoresis (SDSPAGE) (15). Nearly all B. burgdorferi strains produce a $100 \mathrm{kDa}$ protoplasmic cylinder protein which is recognized by a monoclonal antibody. This protein, which has shown to be identical to the $94 \mathrm{kDa}$ and $83 \mathrm{kDa}$ antigens of $B$. burgdorferi, could not be demonstrated in relapsing fever borreliae and in treponemas (23). The $100 \mathrm{kDa}$ protein is supposed to be species- 
specific (18). Two other polypeptides, the $60 \mathrm{kDa}$ protoplasmic protein belonging to the heat-shock family and the immunodominant $41 \mathrm{kDa}$ flagella protein are also present in a wide range of $B$. burgdorferi isolates (24). The $60 \mathrm{kDa}$ protein is the common antigen of $B$. burgdorferi responsible for broad cross-reactivity with other bacteria (25). The $41 \mathrm{kDa}$ flagella protein contains an epitope that binds to a genus-specific monoclonal antibody (26). $B$. burgdorferi contains at least five outer surface proteins (OspA, B, C, D, E and F) which in fact are lipoproteins (27-29). Two of these proteins have molecular masses of $30 \mathrm{kDa}$ to $36 \mathrm{kDa}$ and are designated as OspA (lower molecular mass) and OspB (higher molecular mass) (30). OspA and OspB are antigenically variable, especially in European isolates $(31,32)$. Whereas American $B$. burgdorferi isolates mostly produce an OspA at $31 \mathrm{kDa}$ and an OspB at $34 \mathrm{kDa}$, in European strains OspA varies from $31 \mathrm{kDa}$ to $33 \mathrm{kDa}$ and OspB from $34 \mathrm{kDa}$ to $36 \mathrm{kDa}(33,34)$. In addition, European strains regularly do not produce an OspB $(31,32)$. OspC which is located at about $22 \mathrm{kDa}$ is mainly produced in European strains (35). Whereas OspA and OspB are only weakly immunogenic, OspC is a major protein of the early immune response (35). OspA and OspC are important candidates for a Borrelia vaccine (36-38). The $28 \mathrm{kDa}$ OspD protein has mainly been observed in low-passage strains and may bear virulence factors of $B$. burgdorferi (28). Recently OspE and OspF with molecular masses of about 19

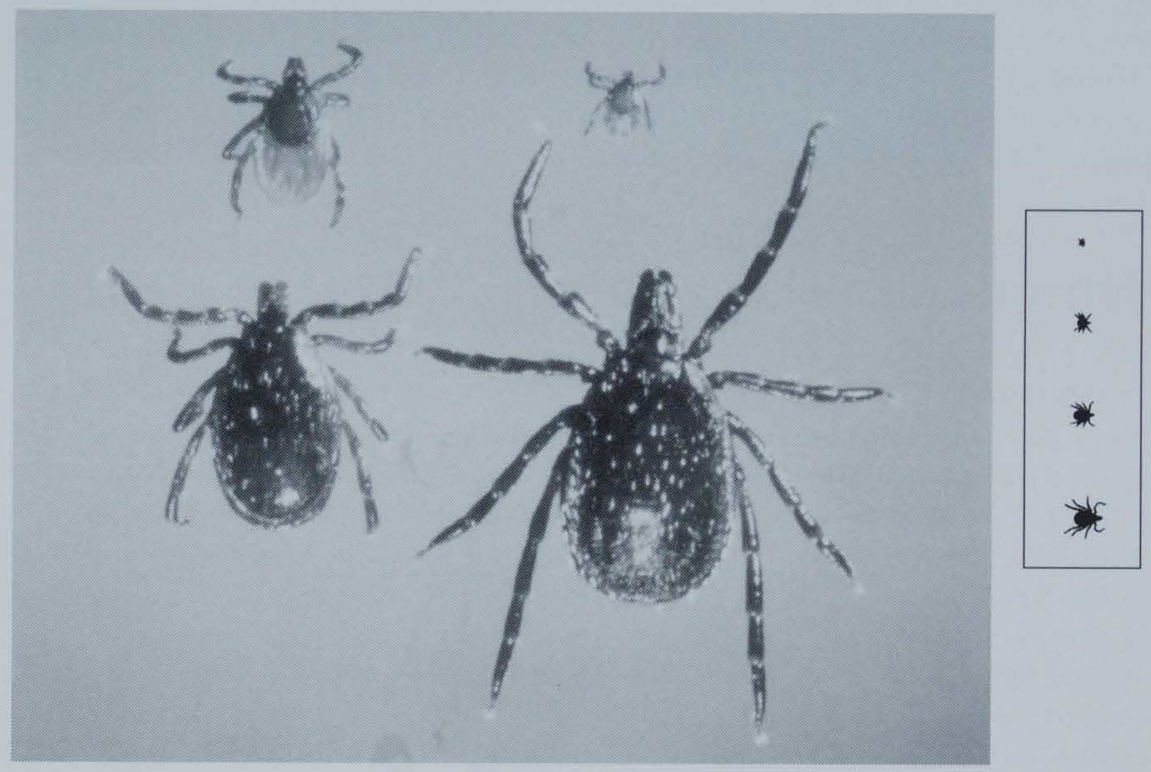

Figure 2. Ixodes ricinus larva (above right), nymph (above left), adult female (below right), and adult male (below left). Drawings in black designate real dimensions. 
$\mathrm{kDa}$ and $29 \mathrm{kDa}$, respectively, have been discovered. OspD through OspF seem to be weakly immunogenic $(28,29)$.

Only limited information is available about non-proteinaceous compounds of $B$. burgdorferi. Studies by Beck et al. (39) have demonstrated that the peptidoglycan of $B$. burgdorferi, which retains the screw-shaped conformation of the spirochete, is closely related chemically to that of other spirochetes. Takayama et al. (40) have studied the chemical composition of the outer cell wall of $B$. burgdorferi. A classical lipopolysaccharide (LPS) as is seen in the outer membrane of other gram-negative bacteria could not be demonstrated. Nevertheless, these and other authors have demonstrated that $B$. burgdorferi contains LPS-like substances.

$B$. burgdorferi has a small chromosome of about $1000 \mathrm{kbp}$, which in contrast to other bacteria is linear (41). Extrachromosomal DNA is present in the form of circular and linear plasmids $(42,43)$. The number of plasmids ranges from three to seven and the plasmid size ranges from 15 to $60 \mathrm{kbp}$. The chromosome encodes for the $100 \mathrm{kDa}$ and the $41 \mathrm{kDa}$ proteins $(44,45)$, whereas linear or circular plasmids encode for the $60 \mathrm{kDa}$ protein and the OspA through OspF lipoproteins $(25,28,46-48)$. Loss of plasmids has been observed after a few in-vitro passages and this phenomenon has been associated with the loss of virulence in laboratory animals (49).

Recently, $B$. burgdorferi sensu lato has been split into $B$. burgdorferi sensu stricto, Borrelia garinii and $B$. burgdorferi group VS461 on the basis of DNA/ DNA hybridization and rRNA gene-restriction patterns (34). All these three genomic species occur in Europe, but $B$. burgdorferi sensu stricto is the only species found so far in the USA $(33,34,50)$. There are indications that the different genomic species of $B$. burgdorferi account for differences in the clinical manifestations of Lyme borreliosis with $B$. burgdorferi group VS461 being associated with cutaneous disorders whereas the other two genomic species are associated with extracutaneous manifestations of Lyme borreliosis $(33,51)$.

\section{VECTOR AND ANIMAL HOSTS}

Lyme borreliosis is transmitted by ticks belonging to the Ixodes ricinus complex. These include Ixodes scapularis in the eastern and mid-western USA, Ixodes pacificus in the western USA, Ixodes persulcatus in Asia and Ixodes ricinus in Europe (52-55). Mosquitos, horse flies and deer flies, as well as other tick species, have been found harbouring $B$. burgdorferi but only ticks of the $I$. ricinus complex seem to be important in transmitting the spirochete to humans $(56,57)$.

Ixodes ticks belong to the family of ixodid or hard-shelled ticks. This family is characterized by a chitinous scutum that, in male ticks covers the entire dorsum, but in female ticks, only the anterior portion of the dorsum (Figure 2). These ticks require the availability of suitable hosts, an environmental temperature between $10^{\circ} \mathrm{C}$ and $35^{\circ} \mathrm{C}$, and a constant relative humidity of at 


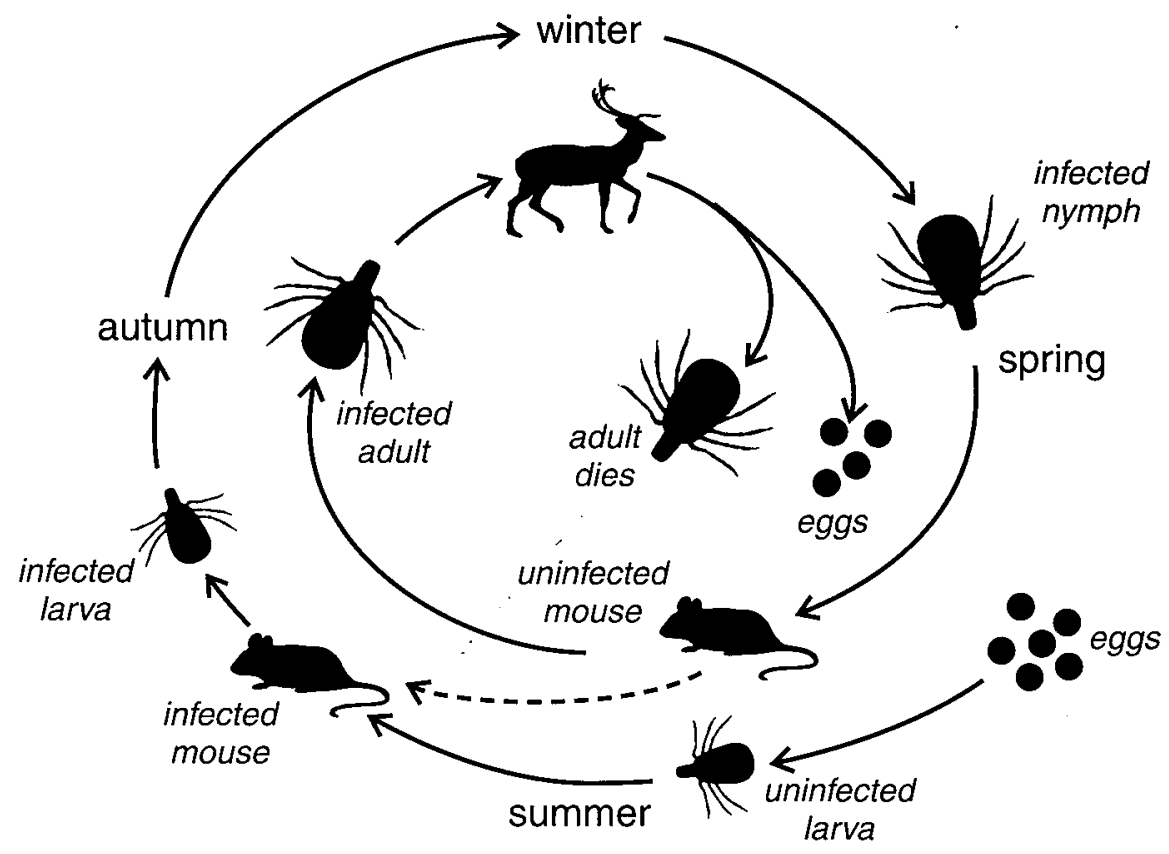

Figure 3. The two-year life cycle of /xodes ricinus ticks transmitting Borrelia burgdorferi. Eggs are deposited in the spring. The six-legged larvae which emerge several weeks later feed once during the summer, usually on mice. Larvae molt during the following spring into eight-legged nymphs, which also once feed during the summer, preferentially on mice. In fall nymphs molt into either female or male adults. Adults attach themselves to larger vertebrates such as deer, where they mate. After mating, the males die, but the females continue to feed to obtain the nutrients necessary for eggs development. Females lay their eggs and die. Domestic animals and humans are incidentally used as hosts for larvae, nymphs and adult ticks.

least $80 \%$. A deciduous forest with damp soil covered by a thick layer of rich underground is the ideal biotope of the tick (58).

Ticks of the $I$. ricinus complex have a life cycle of about two years (Figure 3). During each of the developmental stages i.e. the larva, the nymph and the adult, only one blood meal is taken. Typically, larval ticks feed in late summer, nymphs during the following spring, and adults during that autumn. Depending on the developmental stage of the tick, the feeding session lasts 1 to 7 days $(58,59)$.

The ticks are known to feed upon a large number of animal hosts $(60,61)$. Concerning the transmission of $B$. burgdorferi, these animal hosts can be divided into two groups. One group mainly acts as a feeding target (food source) for the ticks. This group includes birds, larger wild mammals, domes- 
tic animals, and humans. The other group acts not only as feeding target but also as reservoir of $B$. burgdorferi. In the USA as well as in Europe mice are the main hosts for both larval and nymphal ticks $(62,63)$. Mice have found to be tolerant to infection with $B$. burgdorferi and to remain spirochetemic for months (55). Moreover, transmission of $B$. burgdorferi by infected mice can occur through the urine, particularly when these animals are in close contact as in nests or during breeding (64). In The Netherlands, the wood-mouse (Apodemus sylvaticus) is the preferred host for the immature stages of $I$. ricinus and is probably an important reservoir of $B$. burgdorferi (65).

Table 1. Clinical manifestations of Lyme borreliosis by stage.

\begin{tabular}{|c|c|c|c|}
\hline \multirow{2}{*}{ System } & \multicolumn{2}{|c|}{ Early infection } & \multirow{2}{*}{$\begin{array}{l}\text { Late infection } \\
\begin{array}{l}\text { Stage } 3 \\
\text { (persistent) }\end{array}\end{array}$} \\
\hline & $\begin{array}{l}\text { Stage } 1 \\
\text { (localized) }\end{array}$ & $\begin{array}{l}\text { Stage } 2 \\
\text { (disseminated) }\end{array}$ & \\
\hline Skin & $\begin{array}{l}\text { Erythema } \\
\text { migrans }\end{array}$ & $\begin{array}{l}\text { Secondary } \\
\text { erythema migrans } \\
\text { Lymphadenosis } \\
\text { benigna cutis }\end{array}$ & $\begin{array}{l}\text { Acrodermatitis } \\
\text { chronica atrophicans }\end{array}$ \\
\hline Musculoskeletal & & $\begin{array}{l}\text { Migratory arthralgia } \\
\text { Pain in tendons } \\
\text { and muscles } \\
\text { Brief arthritis attacks }\end{array}$ & $\begin{array}{l}\text { Recurrent arthritis } \\
\text { Chronic arthritis }\end{array}$ \\
\hline Neurologic & & $\begin{array}{l}\text { Meningitis } \\
\text { Cranial neuritis } \\
\text { Bell's palsy } \\
\text { Radiculoneuritis }\end{array}$ & $\begin{array}{l}\text { Chronic encephalo- } \\
\text { myelitis } \\
\text { Spastic pareses } \\
\text { Chronic polyradiculo- } \\
\text { pathy }\end{array}$ \\
\hline Lymphatic & $\begin{array}{l}\text { Regional } \\
\text { lymph- } \\
\text { adenopathy }\end{array}$ & $\begin{array}{l}\text { Generalized } \\
\text { lymphadenopathy } \\
\text { Splenomegaly }\end{array}$ & \\
\hline Cardiovascular & & $\begin{array}{l}\text { Varying degrees } \\
\text { of AV block } \\
\text { Myopericarditis }\end{array}$ & \\
\hline Other systems & & $\begin{array}{l}\text { Conjunctivitis } \\
\text { Sore throat } \\
\text { Mild hepatitis } \\
\text { Microscopic } \\
\text { haematuria }\end{array}$ & Keratitis \\
\hline $\begin{array}{l}\text { Constitutional } \\
\text { symptoms }\end{array}$ & Minor & $\begin{array}{l}\text { Severe malaise } \\
\text { and fatigue }\end{array}$ & Fatigue \\
\hline
\end{tabular}


B. burgdorfericauses a persistent infection in the tick's midgut. During feeding, spirochetes penetrate the gut epithelium, disseminate into other tissues including the salivary glands where they are injected into the host by the tick's saliva. The role of regurgitation of spirochete-containing gut material in the transmission of spirochetes has not yet been established. Experimental studies have indicated that transmission of $B$. burgdorferi most often occurs after 48 hours of attachment (66). This observation indicates that prompt removal of ticks is an important measure in preventing Lyme borreliosis.

In the USA the prevalence of $B$. burgdorferi in nymphal and adult ticks reaches extreme values of more than $50 \%$ in certain areas (16). In Europe infection rates of $5-34 \%$ for nymphs and $29 \%$ for adult ticks have been observed in Switzerland $(63,67)$. In Germany $3-26 \%$ of nymphs and 11 $34 \%$ of adult ticks harboured the organism (68). The low infection rate of larvae $(0 \%-3 \%)$ in this study is in accordance with the observations that transovarial transmission of $B$. burgdorferi seldomly occurs (69). Infestation by ticks is possible throughout the year but most frequently occurs between May and October corresponding to the months with the highest tick activity $(59,68)$. The estimated chance of acquiring clinical Lyme borreliosis after the bite of an infected tick is $2-4 \%(70,71)$. Hence, the risk of acquiring clinical Lyme borreliosis after a tick bite in Europe can be estimated to be about $1 \%$.

\section{CLINICAL MANIFESTATIONS}

As with syphilis, Lyme borreliosis generally occurs in three stages with different manifestations at each stage $(16,72,73)$. Asbrink et al. (72) have proposed a classification system in which Lyme borreliosis is divided into early and late phase disease. Stage 1 (localized infection) and stage 2 (disseminated infection), which occur within a few weeks or months after a tick bite, represent the early phase of the disease. Stage 3 (persistent infection) occurs after several months or years and is considered to be the late phase of the disease. The course of Lyme borreliosis may vary considerably. Patients may experience one or all stages and the disease may not become symptomatic until stage 2 and $3(16)$. The clinical manifestations of Lyme borreliosis as described in detail by Rahn (74) are summarized in Table 1. The organs most often affected are the skin, the musculoskeletal system, the nervous system, and the heart.

\section{Skin Manifestations}

Three separate dermatological conditions are associated with Lyme borreliosis: erythema migrans, lymphadenosis benigna cutis and acrodermatitis chronica atrophicans (ACA) $(16,74)$.

The hallmark of acute disease and of the disease in general is erythema migrans, a homogeneous or ring-shaped erythematous and usually perip- 
Figure 4. Erythema migrans of ten days duration on left upper arm of a 46-year old women. Borrelia burgdorferi was isolated from the border of the lesion.

herally expanding skin lesion with central clearing that first occurs at the site of the causative tick bite (Figure 4). Erythema migrans occurs in about $60 \%$ of patients with Lyme borreliosis and is the most common manifestation of the disease both in Europe and in the USA $(16,74)$. Approximately $20 \%$ of erythema migrans lesions contain a central efflorescence consisting of a more intensively stained red macule or a bluish-red papule (75). Central ulceration, blistering or central scaling are rare and may be a nonspecific reaction to the tick bite $(72,75)$. The distinctive appearance of erythema migrans makes it rarely necessary to attempt to microbiological methods to confirm the diagnosis. The duration of erythema migrans may vary from one week to one year, but in European patients frequently lasts longer than four weeks $(75,76)$. Lesions lasting 6 months or more may be called "erythema chronicum migrans" (77). Dissemination of the disease may be accompanied by the appearance of multiple secondary erythema migrans lesions which can be located anywhere on the skin (75). In contrast to the USA where multiple erythema migrans lesions have been reported to occur in $25-50 \%$ of patients, these lesions have only been observed in $4-8 \%$ of cases in Europe (77).

Lymphadenosis benigna cutis is another manifestation of disseminated Lyme borreliosis. This skin lesion has been defined as a bluish-red tumour-like infiltrate with lymphoreticular proliferation in the dermis and/or subcutis. Lymphadenosis benigna cutis can often be observed at particular sites such as the ear lobe or the areola mammae (78). 
The third unique dermatological manifestation of Lyme borreliosis, ACA, can be encountered months or years after the onset of disease. The predilection sites are the acral parts of the limbs, usually on their extensor surfaces. ACA begins with a characteristic bluish-red discoloration, often with a doughy infiltration. This lesion progresses to atrophy of the skin and is sometimes complicated by sclerodermic changes $(79,80)$. About $20 \%$ of patients with ACA have a history consistent with a preceding erythema migrans, usually on the same extremity where the ACA lesion had developed (79). While ACA is a typical feature of European Lyme borreliosis, the condition seldom occurs in the USA (81).

\section{Rheumatological Manifestations}

Musculoskeletal complaints are common throughout the course of Lyme borreliosis and intermittent migratory pain in joints, tendons, bursae, or muscles are the most common rheumatological manifestations. These symptoms are seen in about $20-40 \%$ of patients with erythema migrans $(75,82,83)$. Typically only one or two sites are affected at any one time. Pain can be variable in its intensity and attacks may last from a few hours to a few days. Objective arthritis during the first few months after onset of the infection is unusual $(75,84)$.

Intermittent attacks of arthritis may develop an average of six months after the onset of disease, often at the same extremity that had been bitten by the tick or affected with erythema migrans. Characteristically the arthritis is mono- or oligoarticular and mainly affects large joints, most commonly, the knee, followed by the shoulder, the ankle, elbow and the hip. Attacks of arthritis last one week to several months and the time interval between attacks ranges from months to years. Between attacks, patients commonly complain of arthralgia and fatigue. Attacks of arthritis may recur for several years interspersed with periods of remission which gradually become longer. Eventually, most patients have spontaneous remission of their arthritis, even without treatment (84). In about $10 \%$ of patients, the arthritis takes a more chronic course $(84,85)$, although severe erosion of cartilage and bone appears to be rare. The prevalence of Lyme arthritis seems to be higher in the USA than in Europe. In the USA Steere et al. (84) found 34 out of 55 patients $(62 \%)$ with erythema migrans, who were not treated with antibiotics, to have arthritis. In contrast, Asbrink et al. (76) reported that only one out of 16 Swedish patients developed arthritis after healing of erythema migrans. Hansen et al. (86) have reported the presence of arthritis in only two of 187 (1\%) Danish patients with neurological manifestations of Lyme borreliosis. In patients with ACA concomitant arthritis, mainly of small joints, has been observed in about $10 \%$ of cases (87).

\section{Neurological Manifestations}

Lyme borreliosis is associated with both acute and chronic neurological abnormalities. Patients with erythema migrans frequently have complaints referable to the nervous system. In a study by Steere et al. (82) of 314 patients 
with erythema migrans, $80 \%$ had malaise, fatigue, and lethargy, $64 \%$ had headache, and $48 \%$ had meningeal irritation. These symptoms may or may not be a sign of early dissemination of the disease. The development of meningoradiculoneuritis (Bannwarth's syndrome) provides the best evidence of dissemination (88). This syndrome occurs in about $12-15 \%$ of patients, usually within the first three months after the onset of infection (88-90). Bannwarth's syndrome has clinically been defined as radicular pain, with cerebrospinal fluid lymphocytic pleocytosis, with or without peripheral nerve pareses and with or without cranial nerve affection (91). Whereas in the USA meningitis is frequently the first sign of Bannwarth's syndrome, in Europe the first neurologic sign is characteristically radicular pain $(74,86,89)$. The spectrum of peripheral nervous manifestations is wide, ranging from severe meningopolyneuritis to a relative mild axonal neuropathy $(89,92)$. There is no relation to the site of the tick bite or to erythema migrans. Cranial nerve involvement is seen in about $10 \%$ of patients with Bannwarth's syndrome. Bell's palsy, which may be either unilateral or bilateral, is the most common cranial nerve neuropathy $(88,93)$. Neuroborreliosis is more often encountered in Europe than in the USA.

Some patients may develop encephalomyelitis months to years after the onset of disease, exhibiting mostly spinal or cerebral features which can include spastic pareses, ataxia and mental disorders. According to Kristoferitsch et al. (94), about $50 \%$ of patients with ACA also have some kind of nervous system disorder.

B. burgdorferi infection has been associated with several other neurological disorders including amyotrophic lateral sclerosis and Alzheimer's disease. However, no cause-and-effect relationship has been established for any of these disorders.

\section{Cardiac Manifestations}

Cardiac involvement is less common than either skin, musculoskeletal or neurological manifestations and has been reported to occur in $8 \%$ of North American patients with acute infection (95). Lyme carditis was reported to affect $2-3 \%$ of 817 German patients with Lyme borreliosis(96).

The most common abnormality is a fluctuating atrioventricular block. In thirddegree heart block syncope can occur, but is virtually always self-limiting. Some patients require a temporary pacemaker. Myocarditis and pericarditis can occur but are rarely clinically significant.

As with syphilis, reinfection and congenital infection also seem to be possible with Lyme borreliosis. B. burgdorferi can apparently be transmitted through the placenta to the fetus (98). However, a causal relationship between borrelial fetal invasion and unfavourable outcome of pregnancy has not been shown unequivocally (99).

Experience in several patients has shown that the clinical picture occurring after reinfection is similar to the one seen following primary infection (97). Superinfection also appears possible since the development of an erythema migrans in patients with ACA has been reported (80). 


\section{MICROBIOLOGICAL DIAGNOSIS}

Laboratory methods for the diagnosis of Lyme borreliosis are intended either to detect the causative agent or to measure a specific immune response elicited by $B$. burgdorferi. Methods for the detection of $B$. burgdorferi include microscopy, antigen detection, culture, and DNA techniques.

$B$. burgdorferi induces a humoral and a cellular immune response. The initial immune response is mediated by T-cells. The T-cell response is followed by the production of specific antibodies by B-cells (100).

Hence, demonstration of an immune response to $B$. burgdorferi is possible either by T-cell proliferation assay or serology. Methods for the detection of antibodies to $B$. burgdorferi include immunofluorescent antibody assay (IFA), enzyme immunoassay (EIA) and Western immunoblot.

\section{Microscopy}

B. burgdorferi can be detected in tissues and body fluids using either nonspecific or specific staining techniques (101). Among the non-specific silver impregnation methods the Bosma-Steiner technique has shown to give the best results in terms of contrast and tissue preservation. Using this technique de Koning et al. $(102,103)$ have demonstrated spirochetes in cardiac and skin biopsy specimens of patients with Lyme borreliosis.

Immunochemical techniques using either polyclonal or monoclonal antibodies show specific staining of $B$. burgdorferi. The spirochetes can be visualized by several methods such as immunofluorescence, streptavidine-biotin and immunogold-silver techniques (104-106). All these methods show good contrast but histological structures can only be recognized with the latter two techniques. Strong cross-reaction with peripheral nerve structures has been observed when using monoclonal antibodies against the $41 \mathrm{kDa}$ flagella antigen (107).

Although staining methods have occasionally been useful in confirming the diagnosis of Lyme borreliosis, these methods have no place in routine clinical practice, because they are insensitive due mainly to the low number of $B$. burgdorferi present in tissue and body fluids. In addition, staining methods are laborious and time-consuming, moreover biopsies are not routinely obtained.

\section{Antigen Detection}

Detection of $B$. burgdorferi antigens in body fluids has been reported by Hyde et al. (108) who detected borrelial proteins in the urine of hamsters and of patients with Lyme borreliosis by means of Western blot. The antigens were identified with monoclonal antibodies directed against flagella and outer surface proteins of $B$. burgdorferi. However, since only a few patients were investigated, the diagnostic value of this method remains to be proven. 


\section{Culture}

In-vitro cultivation of $B$. burgdorferi from tissues and body fluids of infected patients has been successful in all stages of Lyme borreliosis but the yield strongly depends on the stage of the illness. B. burgdorferi has been recovered from $57-87 \%$ of erythema migrans lesions and from $40-50 \%$ of ACA lesions $(101,109-112)$, but the recovery rate from blood and CSF has shown to be only $20 \%(113-116)$. B. burgdorferi has only been sporadically isolated from synovial fluid $(117,118)$. Thus, culture has a low sensitivity, especially when diagnosing Lyme borreliosis purely on clinical grounds may be difficult such as in patients presenting with arthritis or neurological abnormalities. Moreover, culture requires at least six weeks before a definitive result can be obtained.

\section{DNA Detection}

Detection of $B$. burgdorferi DNA by means of polymerase chain reaction (PCR) is another method to demonstrate the presence of $B$. burgdorferi in tissues and body fluids $(119,120)$. Recently, Liebling et al. (119) evaluated a PCR using 99 specimens of blood, urine, CSF or synovial fluid from 44 patients suspected of having Lyme borreliosis and from 47 patients with various other diseases. The specificity of the test was uniformly high i.e. $96 \%$ but the sensitivity was dependent upon the body fluid being analysed and was $100 \%$ in CSF and urine, $80 \%$ in synovial fluid, and $59 \%$ in serum. PCR was comparable to culture for biopsies of erythema migrans lesions $(109,119)$. The results of PCR are encouraging but the exact role of this technique in the diagnosis of Lyme borreliosis awaits further study.

\section{T-cell Proliferation Assay}

Patients treated early in the course of Lyme borreliosis may fail to develop detectable levels of antibodies (100). Dattwyler et al. (100) have found a vigorous T-cell proliferation response to whole $B$. burgdorferi cells in 35/35 patients with a history compatible to chronic Lyme borreliosis. Eighteen of these patients had received treatment for acute Lyme borreliosis and had no detectable antibodies to $B$. burgdorferi at the time they presented with symptoms of chronic infection. Although all 17 healthy controls used in this study showed a significant lower T-cell response than patients with Lyme borreliosis, the specificity of this assay in patients who regularly enter the differential diagnosis of chronic Lyme borreliosis has not been established. T-cell proliferation testing requires fresh cells, is difficult to standardize, labour intensive and technically demanding. This method is neither available nor recommended for routine diagnosis. 


\section{Serology}

At present measuring antibodies to $B$. burgdorferi is the only practical method for the laboratory diagnosis of Lyme borreliosis. The most commonly used methods are IFA, EIA and Western blot $(74,122)$ but none is ideal in terms of sensitivity and specificity. Nevertheless, serology can provide useful information when integrated with the patient's history, symptoms and signs. The antibody response to $B$. burgdorferi is quite complex. IgM antibodies are not detectable until six weeks after the onset of infection and IgG antibodies follow within a few weeks and may not peak until months after the onset of disease. IgM antibodies mostly decrease within weeks but in a subset of patients remain high throughout the course of the disease. $\lg G$ antibodies regularly persist for years, especially in patients with initial high titres $(74,122)$. Treatment early in the course of infection may prevent the development of a measurable immune response. Lyme borreliosis may be asymptomatic, especially in patients who are at increased risk of infestation by ticks $(123,124)$.

The initial IgM and IgG response is mainly directed against the $41 \mathrm{kDa}$ flagellin antigen. Later in the course of infection antibodies are produced against several other antigens $(121,125,126)$. The distinction between early and late responses cannot be made by IFA or EIA techniques but it is possible using Western blot, provided early and late serum samples are available.

Nearly all immunodominant proteins of $B$. burgdorferi including the $41 \mathrm{kDa}$ flagella antigen may cross-react with other bacteria, mainly Borrelia species and treponemas. Also, cross reactions occur in those with viral infections or rheumatic disorders $(74,122)$. So, it is not surprising that many apparently healthy individuals show a positive result in serological tests for Lyme borreliosis. There are some proteins that appear to be more specific for Lyme borreliosis such as OspA, OspB and the $100 \mathrm{kDa}$ protoplasmic cylinder protein. However, the response to these proteins is variable, and usually occurs late in the course of infection if at all $(121,125,126)$.

The levels of antibodies measured in Lyme borreliosis not only depend on the stage of the disease and the patients' immune response but also on the serological methods used $(127,128)$. A negative antibody response does not necessarily mean that the patient has no disease. This is especially true in early Lyme borreliosis, in which serological tests vary in their capability to detect low levels of antibodies. There is also considerable intra-and interlaboratory variation with some serological tests

(129). If early Lyme borreliosis is suspected and the diagnosis cannot be made on clinical grounds, another sample should be drawn 4 to 8 weeks later and the acute and convalescent sera should be tested together. 


\section{IFA}

IFA was the first serologic method to be used for the diagnosis of Lyme borreliosis. The procedure is simple and includes adding patients serum to a slide to which $B$. burgdorferi cells have been fixed, followed by washing and incubation with the secondary fluorescent anti-human antibody. The method is especially useful for low-volume testing and has an advantage over EIA in that biologic false-positive results, that may be seen in patients with connective tissue diseases, can be distinguished by an abnormal (beaded) fluorescence pattern (122). However, in all IFA procedures there is a certain degree of subjectivity in reading of the results and experience is required to achieve optimal results. There is variation among manufacturers that probably reflects the use of different $B$. burgdorferistrains, different culture methods and differences in the way slides are prepared $(122,129)$. IFA can be performed without or with preadsorption of sera to Treponema phagedenis antigens. Generally, preadsorption of sera reduces cross-reactivity without loss of sensitivity. Wilske et al. (101) detected elevated IgG or IgM antibody titres in $20-50 \%$ of patients with erythema migrans, $70-90 \%$ of patients with meningoradiculitis, and $90-100 \%$ of patients with ACA after preadsorption.

\section{EIA}

IFAs are being replaced more and more by EIA techniques. EIA is ideal for high-volume testing, and can be used for low-volume testing provided the kit contains separate strips or wells. ElA results are indicated colorimetrically and counted on a continuous scale by a spectrophotometer, thereby overcoming the problems of subjectivity associated with IFA. This may be the main reason why EIA methods have generally scored better in proficiency surveys (122). Nevertheless, EIA is not without problems and many have been shown to perform poorly $(127,128,130)$. Great variability has been demonstrated in the results obtained in different laboratories with the same test kits and among different ones (127-130). Generally, the sensitivity of EIAs in patients with early Lyme borreliosis is low (127). Golightly et al. (127) have studied the degree to which different commercial ElAs pick up low levels of antibodies in early Lyme borreliosis. In patients with erythema migrans of less than one week duration, all eight ElAs studied were negative. In patients with erythema migrans of $1-3$ weeks duration the sensitivities of the assays ranged from $0-57 \%$. These discrepancies are probably due to the use of different $B$. burgdorferi strains, antigen preparations, reagents, and, last but not least, the variety of ways of calculating cut-off values. In order to reduce cross-reactivity fractions of $B$. burgdorferi rather than crude antigens, and preadsorption of serum samples have been advocated (131). However, as the antibody response in Lyme borreliosis is unique to each individual, reducing the number of antigens in the test or eliminating antibodies in the patients' serum may give rise to false-negative results. Hansen et al. $(132,133)$ used a purified flagella EIA increasing the sensitivity of the test in patients with erythema migrans from $17 \%$ to $45 \%$ for $\operatorname{lgM}$ 
and from $11 \%$ to $36 \%$ for IgG (132). In patients with neurological manifestations the sensitivity was increased from $36 \%$ to $68 \%$ for IgM and from $41 \%$ to $77 \%$ for IgG (133). In patients with ACA the crude antigen EIA and the flagella EIA detected IgG antibodies in $98 \%$ and $100 \%$, respectively, and IgM antibodies in $22 \%$ and $12 \%$, respectively (132). Unfortunately, as often is the case, increasing the sensitivity may result in a decrease of specificity and vice versa (122).

\section{Western Immunoblot}

Difficulties with the sensitivity and specificity of IFA and EIA have led to an increasing demand for Western immunoblot to confirm the diagnosis of Lyme borreliosis. This method has the advantage of detecting antibodies to individual components of $B$. burgdorferi $(121,125,126)$. However, there is no consensus on interpreting Western immunoblot band patterns. It is not clear whether positivity should be determined by the number of bands or the type of bands or the intensities of bands $(121,122)$. This uncertainty results from the fact that the band patterns observed in Lyme borreliosis can also be seen frequently in patients with other infections, auto-immune diseases, and in healthy controls $(126,127)$. Some investigators have reported Western immunoblot to be less specific than IFA or EIA, while others have found this technique to be highly specific $(121,126,127)$. The sensitivity of Western immunoblot in early Lyme borreliosis is comparable to that of IFA or EIA (126-134). To improve the sensitivity of immunoblot Wilske et al. (135) have separately studied several recombinant proteins of $B$. burgdorferi including the 41,22 and $100 \mathrm{kDa}$ proteins. In patients with erythema migrans or early neurological manifestations none of the recombinant proteins did exceed the sensitivity of EIA.

\section{INTRODUCTION TO THE THESIS}

Lyme borreliosis is the most common vector-transmitted disease in the USA and in Europe $(16,136)$. From 1980 through 1988 approximately 14,000 cases were reported, mostly from the northeastern, the midwestern and western parts of the USA (16). In Europe cases of Lyme borreliosis have been reported from almost every country (136). For the total population of Central Europe the incidence rate of Lyme borreliosis has been estimated to be $0.05 \%$ to $0.1 \%$ per 100,000 inhabitants per year (136).

Lyme borreliosis has probably been endemic for many years in The Netherlands. Broers (137) had already reported erythema migrans to be the result of a bite of $I$. ricinus as early as 1925 . After the discovery of $B$. burgdorferi in 1982 , the number of reports on Lyme borreliosis increased annually and by 1989 it became apparent that the whole spectrum of clinical manifestations of the illness could be observed (138-144). Simultaneously, the number of requests for $B$. burgdorferi serology increased dramatically, not only to verify the clinical diagnosis but also as a screening method for unspecific symp- 
toms. Reports concerning the diagnostic value of various serological tests for the detection of antibodies to B. burgdorferi are controversial (131) and medical microbiologists are confronted with the problem of making a choice from the increasing number of commercial tests becoming available. In addition, nothing was known in The Netherlands about the epidemiology of the disease and the risk of acquiring Lyme borreliosis after a tick-bite, information which is essential for calculating positive and negative predictive values of serological tests.

The aim of this study was three fold:

1. estimation of the prevalence of $B$. burgdorferi and its genomic species in I. ricinus and localization of high-risk areas for Lyme borreliosis in The Netherlands.

2. estimation of the prevalence of symptomatic and asymptomatic Lyme borreliosis in a population at risk and in the general population.

3. evaluation of the validity of various in-house as well as commercially available laboratory tests for diagnosis of Lyme borreliosis.

In Chapter 2 the effects of medium formulation and culture conditions on the detection level and growth characteristics of $B$. burgdorferi are described. We also analysed the effect of serial cultivation of $B$. burgdorferi on protein profiles, monoclonal antibody reactivity, random amplified polymorphic DNA (RAPD) PCR fingerprints and infectivity for laboratory animals.

In Chapter 3 we investigated the occurrence of $B$. burgdorferi in I. ricinus collected from different parts in The Netherlands using a culture method. The $B$. burgdorferi isolates obtained from this study as well as human skin isolates were genotypically and phenotypically characterized using restriction fragment length polymorphism (RFLP), protein electrophoresis followed by Coomassie blue staining, and reactivity with monoclonal antibodies (Chapter 4).

In Chapter 5 the sensitivities and specificities of five commercially available assays (four EIAs and one haemagglutination assay) were compared with the results obtained with four in-house assays (two ElAs and two IFAs), using different groups of clinically well defined sera. The results obtained with the four commercially available ElAs prompted us to compare these assays with regard to mean test result per study group, precision and cost. The validity of Western immunoblot as a specific confirmatory test for diagnosis of Lyme borreliosis was assessed in Chapter 6 .

In Chapter $\mathbf{7}$ the prevalence of symptomatic and asymptomatic (seropositive) Lyme borreliosis was studied in owners and trainers of gun dogs, a population assumed to be more likely to be exposed to contact with ticks than the average member of the Dutch public. Blood donors, matched for age, sex and residential area, were used as controls. 


\section{REFERENCES}

1. Afzelius A. Verhandlungen der Dermatologischen Gesellschaft zu Stockholm. Archiv für Dermatologie und Syphilis 1910; 101: 404.

2. Afzelius A. Erythema chronicum migrans. Acta Dermato-Venereologica 1921; 2: $120-125$.

3. Garin Ch, Bujadoux. Paralysie par les tiques. Journal de Médicine de Lyon 1922; 71: 765-767.

4. Bannwarth A. Zur Klinik und Pathogenese der "chronischen lymphocytären Meningitis". Archiv für Psychiatrie und Nervenkrankheiten 1944; 117: 161-185.

5. Lennhoff C. Spirochetes in aetiologically obscure diseases. Acta DermatoVenereologica 1948; 28: 295-324.

6. Binder E, Doepfmer R, Hornstein O. Experimentelle Übertragung des Erythema chronicum migrans von Mensch zu Mensch. Hautarzt 1955; 6: 494496.

7. Scrimenti RJ. Erythema chronicum migrans. Archives of Dermatology 1970; 102: 104-105.

8. Steere AC, Malawista SE, Snijdman DR, Shope RE, Andiman WA, Ross MR, Steele RM. Lyme arthritis: an epidemic of oligoarticular arthritis in children and adults in three Connecticut communities. Arthritis and Rheumatism 1977; 20: 7-17.

9. Burgdorfer W, Barbour AG, Hayes SF, Benach JL, Grunwaldt E, Davis JP. Lyme disease - a tick-borne spirochetosis? Science 1982; 216: 1317-1319.

10. Steere AC, Grodzicki RL, Kornblatt AN, Craft JE, Barbour AG, Burgdorfer W, Schmid GP, Johnson E, Malawista SE. The spirochetal etiology of Lyme disease. New England Journal of Medicine 1983; 308: 733-740.

11. Johnson RC, Schmid GP, Hyde FW, Steigerwalt AG, Brenner DJ. Borrelia burgdorferi $\mathrm{sp}$. nov: etiologic agent of Lyme disease. International Journal of Systematic Bacteriology 1984; 34: 496-497.

12. Barbour AG, Burgdorfer W, Hayes SF, Peter O, Aeschlimann A. Isolation of a cultivable spirochete from Ixodes ricinus ticks in Switzerland. Current Microbiology 1983; 8: 123-126.

13. Asbrink E, Hederstedt B, Hovmark A. The spirochetal etiology of erythema chronicum migrans Afzelius. Acta Dermato-Venereologica 1984; 64: 291-295.

14. Pfister HW, EinhäupI KM, Preac-Mursic V, Wilske B, Schierz G. The spirochetal etiology of lymphocytic meningoradiculitis of Bannwarth (Bannwarth's syndrome). Journal of Neurology 1984; 231: 141-144.

15. Barbour AG, Hayes SF. Biology of Borrelia species. Microbiological Reviews 1986; 50: 381-400.

16. Steere AC. Lyme disease. New England Journal of Medicine 1989; 321: 586596.

17. Hovind-Hougen K. Ultrastructure of spirochetes isolated from Ixodes ricinus and Ixodes dammini. Yale Journal of Biology and Medicine 1984; 57: 543-548.

18. Preac-Mursic V, Wilske B. Biology of Borrelia burgdorferi. In: Weber K, Burgdorfer W. Aspects of Lyme borreliosis. Springer- Verlag Berlin Heidelberg 1993: 44-58. 
19. Preac-Mursic V, Wilske B, Schierz G. European Borrelia burgdorferi isolated from humans and ticks: culture conditions and antibiotic susceptibility. Zentralblatt für Bakteriologie und Hygiene [A] 1986; 263: 112-118.

20. Barbour AG. Isolation and cultivation of Lyme disease spirochetes. Yale Journal of Biology and Medicine 1984; 57: 521-525.

21. Kurtti TJ, Munderloh UG, Johnson RC, Ahlstrand GG. Colony formation and morphology in Borrelia burgdorferi. Journal of Clinical Microbiology 1987; 25: 2054-2058.

22. Preac-Mursic V, Wilske B, Reinhardt S. Culture of Borrelia burgdorferi on six solid media. European Journal of Clinical Microbiology 1991; 10: 1076-1079.

23. Ditton HJ, Neuss M, Loller L. Evidence that Borrelia burgdorferi immuno-dominant proteins p100, p94, and p83 are identical. FEMS Microbiology Letters 1992; 94: 217-220.

24. Wilske B, Preac-Mursic V, Schierz G, Busch KV. Immunochemical and immunological analysis of European Borrelia burgdorferi strains. Zentralblatt für Bakteriologie, Mikrobiologie und Hygiene [A] 1986; 263: 92-102.

25. Hansen K, Bangsborg JM, Fjordvang $\mathrm{H}$, Starndberg-Pedersen N, Hindersson P. Immunochemical characterization and isolation of the gene for a Borrelia burg-dorferi immunodominant 60 -kilodalton antigen common to a wide range of bacteria. Infection and Immunity 1988; 56: 2047-2053.

26. Barbour AG, Hayes SF, Heiland RA, Schrumph ME, Tessier SL. A Borrelia genus-specific monoclonal antibody binds to a flagellar epitope. Infection and Immunity 1986; 52: 549-554.

27. Brandt ME, Riley BS, Radolf JD, Norgrad MV. Immunogenic integral membrane proteins of Borrelia burgdorferi are lipoproteins. Infection and Immunity 1990; 58: 983-991.

28. Norris SJ, Caster CJ, Howell JK, Barbour AG. Low-passage-associated proteins of Borrelia burgdorferi B31: characterization and molecular cloning of OspD, a surface-exposed, plasmid-encoded lipoprotein. Infection and Immunity 1992; 60: 4662-4672.

29. Nguyen TK, Lain TT, Barthold SW, Telford SR, Flavell RA, Fikrig E. Partial destruction of Borrelia burgdorferi within ticks that engorged on OspE- or OspFimmunized mice. Infection and Immunity 1994; 62: 2079-2084.

30. Barbour AG, Tessier SL, Hayes SF. Variation in a major surface protein of Lyme disease spirochetes. Infection and Immunity 1984; 45: 94-100.

31. Wilske B, Preac-Mursic V, Schierz G, Kühbeck R, Barbour AG, Kramer M. Antigenic variability of Borrelia burgdorferi. Annals of the New York Academy of Sciences 1988; 539: 126-143.

32. Barbour AG, Schrumph ME. Polymorphisms of major surface proteins of Borrelia burgdorferi. Zentralblatt für Bakteriologie und Hygiene [A] 1986; 263: 8391.

33. Wilske B, Preac-Mursic V, Göbel UB, Graf B, Jauris S, Soutschek E, Schwab E, Zumstein G. An OspA serotyping system for Borrelia burgdorferi based on reactivity with monoclonal antibodies and OspA sequence analysis. Journal of Clinical Microbiology 1993; 31: 340-350.

34. Baranton G, Postic D, Saint Girons I, Boerlin P, Piffaretti JC, Assous M, Grimont PA. Delineation of Borrelia burgdorferi sensu stricto, Borrelia garinii sp. nov., and group VS461 associated with Lyme borreliosis. International Journal of Systematic Bacteriology 1992; 42: 378-383. 
35. Wilske B, Preac-Mursic V, Jauris S, Hofmann A, Pradel I, Soutschek E, Schwab E, Will G, Wanner G. Immunological and molecular polymorphisms of OspC, an immunodominant major outer surface protein of Borrelia burgdorferi. Infection and Immunity 1993; 61: 2182-2191.

36. Gern L, Rais O, Capiau C, Hauser P, Lobet $Y$, Simoen E, Voet P, Pêtre J. Immunization of mice by recombinant OspA preparations and protection against Borrelia burgdorferi infection induced by Ixodes ricinus tick bites. Immunology Letters 1994; 39: 249-258.

37. Stover CK, Bansal GP, Hanson MS, Burlein JE, Palaszynski SR, Young JF, Koenig S, Young DB, Sadziene A, Barbour AG. Protective immunity elicited by recombinant Bacille Calmette-Guerin (BCG) expressing outer surface protein A (OspA) lipoprotein: a candidate Lyme disease vaccine. Journal of Experimental Medicine 1993; 179: 197-209.

38. Preac-Mursic V, Wilske B, Patsouris E, Jauris S, Will G, Soutschek E, Rainhardt $S$, Lehnert G, Klockmann U, Mehraein P. Active immunization with pC protein of Borrelia burgdorferi protects gerbils against Borrelia burgdorferi infection. Infection 1992; 20: 342-349.

39. Beck G, Habicht GS. Isolation and biological activity of Borrelia burgdorferi peptidoglycan. Annals of the New York Academy of Sciences 1988; 539: 365366.

40. Takayama K, Rothenberg RJ, Barbour AG. Absence of lipopolysaccharide in the Lyme disease spirochete, Borrelia burgdorferi. Infection and Immunity 1987; 55: 2311-2313.

41. Basil C, Richaud C, Baranton G, Saint Girons I. Linear chromosome of Borrelia burgdorferi. Research in Microbiology 1989; 140: 507-516.

42. Barbour AG. Plasmid analysis of Borrelia burgdorferi, the Lyme borreliosis agent. Journal of Clinical Microbiology 1988; 26: 475-478.

43. Barbour AG, Garon CF. Linear plasmids of the bacterium Borrelia burgdorferi have covalently closed ends. Science 1987; 237: 409-411.

44. LeFebre RB, Perng GC, Johnson RC. The 83-kilodalton antigen of Borrelia burgdorferi which stimulates immunoglobulin $\mathrm{M}$ (IgM) and IgG responses in infected hosts is expressed by a chromosomal gene. Journal of Clinical Microbiology 1990; 28: 1673-1675.

45. Wallich R, Moter SE, Simon MM, Ebnet K, Heiberger A, Kramer MD. The Borrelia burgdorferiflagellum-associated 41-kilodalton antigen (flagellin): molecular cloning, expression, and amplification of the gene. Infection and Immunity 1990; 58: 1711-1719.

46. Bergström S, Bundoc VG, Barbour AG. Molecular analysis of linear plasmidencoded major surface proteins, OspA and OspB, of the Lyme disease spirochaete Borrelia burgdorferi. Molecular Microbiology 1989; 3: 479-486.

47. Sadziene A, Wilske B, Ferdows MS, Barbour AG. The cryptic OspC gene of Borrelia burgdorferi B31 is located on a circular plasmid. Infection and Immunity 1993; 61: 2192-2195.

48. Lam TT, Nguyen PK, Montgomery RR, Kantor FS, Fikrig E, Flavell RA. Outer surface proteins $E$ and $F$ of Borrelia burgdorferi, the agent of Lyme disease. Infection and Immunity 1994; 62: 290-298.

49. Schwan TG, Burgdorfer W, Garon CF. Changes in infectivity and plasmid profile of the Lyme disease spirochete, Borrelia burgdorferi, as a result of in-vitro cultivation. Infection and Immunity 1988; 56: 1831-1836. 
50. Wallich R, Helmes C, Schaible UE, Lobet $\mathrm{Y}$, Moter SE, Kramer MD, Simon MM. Evaluation of genetic divergence among Borrelia burgdorferi isolates by use of OspA, fla, HSP60, and HSP70 gene probes. Infection and Immunity 1992; 60: 4856-4866.

51. van Dam AP, Kuiper H, Vos K, Widjojokusumo A, de Jongh BM, Spanjaard L, Ramselaar ACP, Kramer MD, Dankert J. Different genospecies of Borrelia burgdorferi are associated with distinct clinical manifestations of Lyme borreliosis. Clinical Infectious Diseases 1993; 17: 708-717.

52. Sigal LH, Curran AS. Lyme disease: a multifocal worldwide epidemic. Annual Review of Public Health 1991; 12: 85-109.

53. Wesson DM, McLain DK, Oliver JH, Piesman J, Collins FH. Investigation of the validity of species status of Ixodes dammini (Acari: Ixodidae) using rDNA. Proceedings of the National Academy of Science 1993; 90: 10221-10225.

54. Dekonenko EJ, Steere AC, Berardi VP, Kravchuk LN. Lyme borreliosis in the Soviet Union: a cooperative US-USSR report. Journal of Infectious Diseases 1988; 158: 748-753.

55. Burgdorfer W, Lane RS, Barbour AG, Gresbrink RA, Anderson JF. The western black-legged tick, Ixodes pacificus: a vector of Borrelia burgdorferi. American Journal of Tropical Medicine and Hygiene 1985; 34: 925-930.

56. Magnarelli LA, Anderson JF, Barbour AG. The etiologic agent of Lyme disease in deer flies, horse flies and mosquitos. Journal of Infectious Diseases 1986; 154: 355-358.

57. Schulze TL, Bowen GS, Bosler EM, Lakat MF, Parkin WE, Altman R, Ormiston BG, Shisler JK. Amblyomma americanum: a potential vector of Lyme disease in New Jersey. Science 1984; 224: 601-603.

58. Gern L, Burgdorfer W, Aeschlimann A, Krampitz HE. The ecology of Lyme borreliosis in Europe. In: Weber K, Burgdorfer W. Aspects of Lyme borreliosis. Springer Verlag Berlin Heidelberg 1993: 59-69.

59. Wilson ML, Spielman A. Seasonal activity of immature Ixodes dammini (Acari: Ixodidae). Journal of Medical Entomology 1985; 22: 408-414.

60. Jaenson TGT. The epidemiology of Lyme borreliosis. Parasitology Today 1991; 7: 39-45.

61. Mather TN, Wilson ML, Moore SI, Ribeiro JMC, Spielman A. Comparing the relative potential of rodents as reservoirs of the Lyme disease spirochete (Borrelia burgdorferi). American Journal of Epidemiology 1989; 130: 143-150.

62. Levine JF, Wilson ML, Spielman A. Mice as reservoirs of the Lyme disease spirochete. American Journal of Tropical Medicine and Hygiene 1985; 34: 355360.

63. Aeschlimann A, Chamot E, Gigon F, Jeanneret JP, Kesseler D, Walther C. Borrelia burgdorferi in Switzerland. Zentralblatt für Bakteriologie, Mikrobiologie und Hygiene [A] 1986; 263: 450-458.

64. Burgess EC, Amundson TE, Davis JP, Kaslow RA, Edelman R. Experimental inoculation of Peromyscus spp. with Borrelia burgdorferi: evidence of contact transmission. American Journal of Tropical Medicine and Hygiene 1986; 35: 355-359.

65. de Boer R, Hovius KE, Nohlmans MKE, Gray JS. The woodmouse (Apodemus sy/vaticus) as a reservoir of tick transmitted spirochetes (Borrelia burgdorferi) in the Netherlands. Zentralblatt für Bakteriologie, Mikrobiologie und Hygiene 1993; 279: 404-416. 
66. Ribeiro JM, Mather TN, Piesman J, Spielman A. Dissemination and salivary delivery of Lyme disease spirochetes in vector ticks (Acari: Ixodidae). Journal of Medical Entomology 1987; 24: 201-205.

67. Burgdorfer W, Barbour AG, Hayes SF, Peter O, Aeschlimann A. Erythema chronicum migrans - a tickborne spirochetosis. Acta Tropica (Basel) 1983; 40: 79-83.

68. Wilske B, Steinhuber R, Bergmeister H, Fingerle V, Schierz G, Preac-Mursic V, Vanek E, Lorbeer B. Lyme borreliose in Süddeutschland. Deutsche Medizinische Wochenschrift 1987; 112: 1730-1736.

69. Magnarelli LA, Anderson JF, Fisch D. Transovarial transmission of Borrelia burgdorferi in Ixodes dammini (Acari: Ixodidae). Journal of Infectious Diseases 1987; 156: 234-236.

70. Paul H, Gerth HJ, Ackermann R. Infectiousness of humans of Ixodes ricinus containing Borrelia burgdorferi. Zentralblatt für Bakteriologie, Mikrobiologie und Hygiene [A] 1987; 263: 473-476.

71. Schmutzhard E, Stanek G, Pletschette M, HirschIAM, PalluaA, Schmitzberger R, Schlögl R. Infections following tickbites. Tick-borne encephalitis and Lyme borreliosis - a prospective epidemiological study from Tyrol. Infection 1988; 16: 269-272.

72. Asbrink E, Hovmark A. Early and late cutaneous manifestations in Ixodesborne borreliosis (erythema migrans borreliosis, Lyme borreliosis). Annals of the New York Academy of Sciences 1988; 539: 4-15.

73. Weber K, Schierz G, Wilske B, Preac-Mursic V. European erythema migrans disease and related disorders. Yale Journal of Biology and Medicine 1984; 57 : 463-471.

74. Rahn DW. Lyme disease: clinical manifestations, diagnosis and treatment. Seminars in Arthritis and Rheumatism 1991; 20: 201-218.

75. Weber K, Neubert U. Clinical features of early erythema migrans disease and related disorders. Zentralblatt für Bakteriologie, Mikrobiologie und Hygiene [A] 1986; 263: 209-228.

76. Asbrink $\mathrm{E}$, Olsson I. Clinical manifestations of erythema chronicum migrans Afzelius in 161 patients. Acta Dermato-Venereologica 1985; 65: 43-52.

77. Weber K, Neubert U, Büchner SA. Erythema migrans and early signs and symptoms. In: Weber K, Burgdorfer W. Aspects of Lyme borreliosis. SpringerVerlag Berlin Heidelberg 1993: 105-121.

78. Asbrink E, HovmarkA, Olsson 1. Lymphadenosis benigna cutis solitaria-borrelia lymphocytoma in Sweden. Zentralblatt für Bakteriologie, Supplement 1989: 18: 156-163.

79. Asbrink E, Hovmark A, Olsson I. Clinical manifestations of acrodermatitis chronica atrophicans in 50 Swedish patients. Zentralblatt für Bakteriologie und Hygiene [A] 1986; 263: 253-261.

80. Asbrink E, Hovmark A, Hedersted B. The spirochetal etiology of acrodermatitis atrophicans Herxheimer. Acta Dermato-Venereologica 1984; 64: 506-512.

81. Kaufman LD, Gruber BL, Phillips ME, Benach JL. Late cutaneous Lyme disease: acrodermatitis chronica atrophicans. American Journal of Medicine 1989; 86: 828-830. 


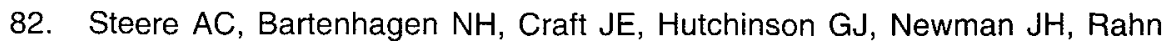
DW, Sigal LH, Spieler PN, Stenn KS, Malawista SE. The early clinical manifestations of Lyme disease. Annals of Internal Medicine 1983; 99: 76-82.

83. Steere AC, Bartenhagen NH, Craft JE, Hutchinson GJ, Newman JH, Pachner AR, Rahn DW, Sigal LH, Taylor E, Malawista SE. Clinical manifestations of Lyme disease. Zentralblatt für Bakteriologie und Hygiene [A] 1986; 263: 201 205.

84. Steere AC, Schoen RT, Taylor E. The clinical evolution of Lyme arthritis. Annals of Internal Medicine 1987; 107: 725-731.

85. Steere AC, Taylor E, Wilson ML, Levine JF, Spielman A. Longitudinal assessment of the clinical and epidemiological features of Lyme disease in a defined population. Journal of Infectious Diseases 1986; 154: 295-300.

86. Hansen K, Lebech AM. The clinical and epidemiological profile of Lyme neuroborreliosis in Denmark 1985-1990. Brain 1992; 115: 399-423.

87. Hovmark A, Asbrink E, Olsson I. Joint and bone involvement in Swedisch patients with Ixodes ricinus-borne borrelia infection. Zentralblatt für Bakteriologie, Mikrobiologie und Hygiene 1986; 263: 275-284.

88. PachnerAR, Steere AC, Bartenhagen NH, Shope RE, Malawista SE. The triad of neurologic manifestations of Lyme disease: meningitis, cranial neuritis and radiculoneuritis. Neurology 1985; 35: 47-53.

89. Kristoferitsch W. Lyme borreliosis in Europe: neurologic disorders. Rheumatic Disease Clinics of North America 1989; 15: 767-774.

90. Finkel MF. Lyme disease and its neurologic comlications. Archives of Neurology 1988; 45: 99-104.

91. Kristoferitsch W. Neurological manifestations of Lyme borreliosis: clinical definition and differential diagnosis. Scandinavian Journal of Infectious Diseases, Supplement 1991; 77: 64-73.

92. Halperin JJ, Pass HL, Anand AK, Luft BJ, Volkmans DJ, Dattwyler RJ. Nervous system abnormalities in Lyme disease. Annals of the New York Academy of Sciences 1988; 539: 24-34.

93. Clark JR, Carlson RD, Sasaki CT, Pachner AR, Steere AC. Facial paralysis in Lyme disease. Laryngoscope 1985; 95: 1341-1345.

94. Kristoferitsch W, Sluga E, Graf M, Partsch H, Neumann R, Stanek G, Budka H. Neuropathy associated with acrodermatitis chronica atrophicans, clinical and morphological features. Annals of the New York Academy of Sciences 1988; 539: 35-45.

95. Steere AC, Batsford WP, Weinberg M, Alexander J, Berger HJ, Wolfson S, Malawista SE. Lyme carditis: cardiac abnormalities of Lyme disease. Annals of Internal Medicine 1980; 93: 8-16.

96. Schmidt R, Kabatzki J, Hastung S, Ackermann R. Erythema-migrans-Borreliose in der Bundesrepublik Deutschland: Epidemiologie und klinisches Bild. Deutsche Medizinische Wochenschrift 1985; 110: 1803-1807.

97. Weber K, Schierz G, Wilske B, Neubert U, Krampitz HE, Barbour AG, Burgdorfer $W$. Reinfection in erythema migrans disease. Infection 1986; 14 : 32-35.

98. Weber K, Bratzke HJ, Neubert U, Wilske B, Duray PH. Borrelia burgdorferi in a newborn despite oral penicillin for Lyme borreliosis during pregnancy. Pediatric Infectious Diseases Journal 1988; 7: 286-289. 
99. Strobino BA, Williams CL, Abid S, Chalson R, Spierling P. Lyme disease and pregnancy outcome - a prospective study of 2000 prenatal patients. American Journal of Obstetrics and Gynaecology 1993; 169: 367-374.

100. Dattwyler RJ, Volkman DJ, Luft BJ, Halperin JJ, Thomas J, Golightly MG. Dissociation of specific $T$ - and B-lymphocytes responses to $B$. burgdorferi. New England Journal of Medicine 1988; 319: 1441-1446.

101. Wilske B, Preac-Mursic V. Microbiological Diagnosis of Lyme borreliosis. In: Weber K, Burgdorfer W. Aspects of Lyme borreliosis. Springer-Verlag Berlin Heidelberg 1993: 267-299.

102. de Koning J, Bosma RB, Hoogkamp-Korstanje JAA. Demonstration of spirochetes in patients with Lyme disease with a modified silver stain. Journal of Medical Microbiology 1987; 23: 261-267.

103. de Koning J, Hoogkamp-Korstanje JAA, van der Linde MR, Crijns HJ. Demonstration of spirochetes in cardiac biopsies of patients with Lyme disease. Journal of Infectious Diseases 1989; 160: 150-153.

104. Holgate CS, Jackson P, Cowen PN, Bird CC. Immunogold-silver staining: new method of immunostaining with enhanced sensitivity. Journal of Histochemistry and Cytochemistry 1983; 31: 177-186.

105. Park HK, Jones BE, Barbour AG. Erythema chronicum migrans of Lyme disease: diagnosis by monoclonal antibodies. Journal of the American Academy of Dermatology 1986; 15: 406-410.

106. Jennings BR, Minces H, Turner J, Baselski V, Kelly RT. Use of avidin-biotinylated horseradish peroxidase complex for visualization of spirochetes. Journal of Clinical Microbiology 1983; 18: 1250-1251.

107. Sigal LH, Tatum AH. Lyme disease patients' serum contains IgM antibodies to B. burgdorferi that cross-react with neural antigens. Neurology 1988; 38: 14391442.

108. Hyde FW, Johnson RC, White TJ, Shelburne CE. Detection of antigens in urine of mice and humans infected with Borrelia burgdorferi, etiologic agent of Lyme disease. Journal of Clinical Microbiology 1989; 27: 58-61.

109. Schwartz I, Wormser GP, Schwartz JJ, Cooper D, Weissensee P, Gazumyan A, Zimmermann E, Goldberg NS, Bittker S, Campbell GL, Pavia CS. Diagnosis of early Lyme disease by polymerase chain reaction amplification and culture of skin biopsies from erythema migrans. Journal of Clinical Microbiology 1992; 30: 3082-3088.

110. Berger BW, Johnson RC, Kodner C, Coleman L. Cultivation of Borrelia burgdorferi from erythema migrans lesions and perilesional skin. Journal of Clinical Microbiology 1992; 30: 359-361.

111. Asbrink E, Hovmark A. Successful cultivation of spirochetes from skin lesions of patients with erythema chronicum migrans Afzelius and acrodermatitis chronica atrophicans. Acta Pathologica Microbiologica et Immunologica Scandinavia 1985; 93: 161-163.

112. Kuiper H, Cairo I, van Dam A, de Jongh B, Ramselaar T, Spanjaard L, Dankert J. Solitary erythema migrans: a clinical laboratory and epidemiological study of 77 Dutch patients. British Journal of Dermatology 1994; 130: 466472.

113. Nadelman RB, Pavia CS, Magnarelli LA, Wormser GP. Isolation of Borrelia burgdorferi from the blood of seven patients with Lyme disease. American Journal of Medicine 1990; 88: 21-26. 
114. Benach JL, Bosler EM, Hanrahan JP, Coleman JL, Habicht GS, Bast TF, Cameron DJ, Ziegler JL, Barbour AG, Burgdorfer W, Edelman R, Kaslow RA. Spirochetes isolated from the blood of two patients with Lyme disease. New England Journal of Medicine 1983; 308: 740-742.

115. Karlsson M, Hovind-Hougen K, Svenungsson B, Stiernstedt G. Cultivation and characterization of spirochetes from cerebrospinal fluid of patients with Lyme borreliosis. Journal of Clinical Microbiology 1990; 28: 473-479.

116. Rawlings JA, Fournier PV, Teltow GJ. Isolation of Borrelia spirochetes from patients in Texas. Journal of Clinical Microbiology 1987; 25: 1148-1150.

117. Snydman DR, Schenkein DP, Berardi VP, Lastavica CC, Pariser KM. Borrelia burgdorferi in joint fluid in chronic Lyme arthritis. Annals of Internal Medicine 1986; 104: 798-800.

118. Schmidli J, HunzikerT, Moesli P, Schaad UB. Cultivation of Borrelia burgdorferi from joint fluid three months after treatment of facial palsy due to Lyme borreliosis. Journal of Infectious Diseases 1988; 158: 905-906.

119. Liebling MR, Nishio MJ, Rodriquez A, Sigal LH, Jin T, Louie JS. The polymerase chain reaction for the detection of Borrelia burgdorferi in human body fluids. Arthritis and Rheumatism 1993; 36: 665-675.

120. Melchers W, Meis J, Rosa P, Claas E, Nohlmans L, Koopman R, Horrevorts A, Galama J. Amplification of Borrelia burgdorferi DNA in skin biopsies from patients with Lyme disease. Journal of Clinical Microbiology 1991; 29: 24012406.

121. Cutler SJ, Wright DJM. Predictive value of serology in diagnosing Lyme borreliosis. Journal of Clinical Pathology 1994; 47: 344-349.

122. Golightly MG. Laboratory considerations in the diagnosis and management of Lyme borreliosis. Clinical Pathology 1992; 99: 168-174.

123. Kuiper H, van Dam AP, Moll van Charante AW, Nauta NP, Dankert J. One year follow-up study to assess the prevalence and incidence of Lyme borreliosis among dutch forestry workers. European Journal of Clinical Microbiology and Infectious Diseases 1993; 12: 413-418.

124. Fahrer $H$, van der Linden $S M$, Sauvain MJ, Gern L, Zhioua E, Aeschlimann $A$. The prevalence and incidence of clinical and asymptomatic Lyme borreliosis in a population at risk. Journal of Infectious Diseases 1991; 163: 305-310.

125. Dressler F, Whalen JA, Reinhardt BN, SteereAC. Western blotting in the serodiagnosis of Lyme disease. Journal of Infectious diseases 1993; 167: 392400 .

126. Zöller L, Burkard S, Schäfer H. Validity of Western immunoblot band patterns in the serodiagnosis of Lyme borreliosis. Journal of Clinical Microbiology 1991: 29: 174-182.

127. Golightly MG, Viciana AL. ELISA and immunoblots in the diagnosis of Lyme borreliosis: sensitivities and sources of false-positive results. In: Schutzer S. Lyme disease: molecular and immunologic approaches. Cold Spring Harbor, NY: Cold Spring Harbor Laboratory Press 1992: 283-297.

128. Schwartz BS, Goldstein MD, Ribeiro JMC, Schulze TL, Shahied SI. Antibody testing in Lyme disease: a comparison of results in four laboratories. Journal of the American Medical Association 1989; 262: 3431-3434.

129. Luger SW, Krauss E. Serologic tests for Lyme disease: interlaboratory variability. Archives in Internal Medicine 1990; 150: 761-763. 
130. Fister RD, Weymouth LA, Mc Laughlin JC, Ryan RW, Tilton RC. Comparative evaluation of three products for the detection of Borrelia burgdorferi antibody in human serum. Journal of Clinical Microbiology 1989; 27: 234-237.

131. Stiernstedt G, Dattwyler R, Duray PH, Hansen K, Jirous J, Johnson RC, Karlsson M, Preac-Mursic V, Schwan TG. Diagnostic tests in Lyme borreliosis. Scandinavian Journal of Infectious Diseases 1991; 77: 136-142.

132. Hansen $\mathrm{K}$, Asbrink $E$. Serodiagnosis of erythema migrans and acrodermatitis chronica atrophicans by the Borrelia burgdorferi flagellum enzyme-linked immunosorbent assay. Journal of Clinical Microbiology 1989; 27: 545-541.

133. Hansen K, Hindersson $P$, Strandberg-Pedersen N. Measurement of antibodies to the Borrelia burgdorferi flagellum improves serodiagnosis in Lyme disease. Journal of Clinical Microbiology 1988; 26: 338-346.

134. Rose CD, Fawcett PT, Singsen BH, Dubbs SB, Doughty RA. Use of Western blot and enzyme-linked immunosorbent assays to assist in the diagnosis of Lyme disease. Pediatrics 1991; 88: 465-470.

135. Wilske B, Fingerle V, Herzer P, Hofmann A, Lehnert G, Peters H, Pfister HW, Preac-Mursic V, Soutschek E, Weber K. Recombinant immunoblot in the serodiagnosis of Lyme borreliosis. Medical Microbiology and Immunology 1993; 182: 255-270.

136. Stanek G, Salz N, Strle F, Wilske B. Epidemiology of Lyme borreliose. In: Weber K, Burgdorfer W. Aspects of Lyme borreliose. Springer Verlag Berlin Heidelberg 1993: 358-370.

137. Broers JH. Over de door Ixodes ricinus, hondeteek, veroorzaakte huidaandoeningen. Nederlands Tijdschrift voor Geneeskunde 1925; 69: 1824-1826.

138. van Furth R. Lyme disease: een nieuwe infectieziekte met lokalisatie in verschillende organen. Nederlands Tijdschrift voor Geneeskunde 1987; 131: 657-658.

139. Kuiper $\mathrm{H}$, de Jongh BM, Senden PJ. Pacemaker-implantatie wegens totaal atrioventriculair block bij Lyme-borreliose. Nederlands Tijdschrift voor $\mathrm{Ge}$ neeskunde 1988; 132: 2109-2111.

140. Blaauw AAM, Braat $S$, van Santen-Hoeufft HM, van der Linden SJ. Cardiologische afwijkingen bij patienten met Lyme-borreliose. Nederlands Tijdschrift voor Geneeskunde 1988; 132: 2111-2114.

141. van den Hoogen FH, Boerbooms AM, Rasker JJ, van de Putte LB. Gewrichtsklachten na tekebeet: Lyme-arthritis in Nederland. Nederlands Tijdschrift voor Geneeskunde 1988; 132: 1300-1303.

142. Wokke JHJ, Vanneste JAL, Vermeulen M, Op de Coul AAW, Overbeek HC, Janssen RMCM, Brouwer R. Lymfocytaire meningoradiculitis na insektebeet (syndroom van Bannwarth). Nederlands Tijdschrift voor Geneeskunde 1984; 128: 1796-1799.

143. van Everdingen JJE. De samenhang tussen Lyme ziekte, erythema chronicum migrans en acrodermatitis chronica atrophicans. Nederlands Tijdschrift voor Geneeskunde 1984; 128: 1018-1019.

144. de Koning J. De lokalisatie van spirocheten in lymphadenosis cutis benigna. Nederlands Tijdschrift voor Geneeskunde 1987; 131: 80. 


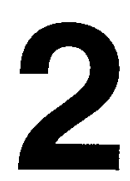

\section{ISOLATION AND CULTIVATION OF BORRELIA BURGDORFERI}

MKE Nohlmans ${ }^{1}$, JFGM Meis ${ }^{2}$, WJG Melchers ${ }^{2}$, AEJM van den Bogaard', JAA Hoogkamp-Korstanje ${ }^{2}$

1 Department of Medical Microbiology, State University of Limburg, Maastricht;

2 Department of Medical Microbiology and Infectious Diseases, University Hospital Nijmegen, Nijmegen, The Netherlands.

Partly published in the Nederlands Tijdschrift voor Geneeskunde 1989; 133: 2262. Partly submitted for publication. 


\section{ISOLATION AND CULTIVATION \\ OF BORRELIA BURGDORFERI}

\section{ABSTRACT}

In this chapter, attention is focused on the isolation and cultivation of Borrelia burgdorferi. 1) Is it possible to leave out rabbit serum from the BSKII medium without loss of optimal growth. 2) What is the sensitivity of our previously used method to isolate Borrelia burgdorferi from Ixodes ricinus using BSKII with the addition of antibiotics. 3) Is it possible to obtain discrete colonies by simply solidifying BSKII. 4) Does repeated subculturing of Borrelia burgdorferi cause changes in protein profile, reactivity with monoclonal antibodies, polymerase chain reaction fingerprint, and infectivity for laboratory animals, and are these possible changes related to the culture medium used. Our results indicate that rabbit serum can be omitted from BSKII provided that a crude bovine serum albumin preparation is used and neopeptone is dissolved in boiling water. Using the laboratory adapted strain B31, BSKIl with the addition of $100 \mu \mathrm{g} / \mathrm{ml}$ neomycin, $256 \mu \mathrm{g} / \mathrm{ml}$ sulphamethoxazole and $64 \mu \mathrm{g} / \mathrm{ml}$ trimethoprim supported the growth of approximately 2 spirochetes. Nevertheless, when BSKII with and without antibiotics was used in parallel to isolate Borrelia burgdorferi from the organs of experimentally infected rats, the recovery rate in the medium without antibiotics was considerably higher than in the selective medium. Solidifying BSKII with agar and agarose both resulted in growth of Borrelia burgdorferi. However, the best results in terms of recovery rate, formation of individual colonies and colony diameter were obtained with $1.25 \%$ agarose. Repeated subculturing of three Dutch /xodes ricinus isolates did not cause changes in protein profiles, MAb reactivities and PCR fingerprints neither in the complete BSKII medium nor in BSKII without rabbit serum. However, infectivity of these isolates in Lewis rats was lost after they had been passaged forty times in BSKII.

\section{INTRODUCTION}

Since the discovery of Borrelia burgdorferi, the aetiologic agent of Lyme borreliosis, by Willy Burgdorfer in 1981 (1) isolation and cultivation of this tick-borne spirochete has gained much attention. Several arguments can be adduced to stress the importance of optimal techniques for isolation and cultivation of $B$. burgdorferi. First, isolation of the causative agent from tissues and body fluids is helpful in the diagnosis of Lyme borreliosis, especially in early disease when serological tests tend to be negative (2). Second, culture techniques which are optimally conducive to borrelial growth 
are needed in order to prepare antigens for serological tests $(3,4)$. Third, isolation and cultivation of $B$. burgdorferi from human, animal and tick specimens are important aids in elucidating the epidemiology and pathogenesis of Lyme borreliosis $(5,6,7)$. Finally, culture is a necessary tool in testing the antimicrobial susceptibility of $B$. burgdorferi and in molecular biological and immunological research $(8,9)$.

The formulas used nowadays for the isolation and cultivation of $B$. burgdorferi are derived mainly from experience with other Borrelia species (10). Especially the successful cultivation of Borrelia hermsii by Kelly in 1971 constitutes a cornerstone in the history of development of Borrelia culture (11). Kelly enriched previous concoctions with $\mathrm{N}$-acetylglucosamine, a major constituent of peptidoglycan which is also, coincidentally or not, the primary building block for the chitin in a tick's cuticle. Stoenner et al. (12) "fortified" Kelly's medium by adding yeast extract and concentrated tissue culture mixture, and Barbour subsequently improved the buffering capacity (13). Various modifications of the original Barbour-Stoenner-Kelly (BSKI) medium and the later modification BSKII (10), with and without the addition of antibiotics, are now routinely used to grow $B$. burgdorferi. However, it is not known which of the components in these media stimulate or restrain the growth of $B$. burgdorferi.

The passage of relapsing fever Borrelia through arthropod vectors, vertebrate host and culture systems is postulated to cause changes in their antigenicity, virulence, and infectivity (14). In $B$. burgdorferi loss of infectivity for hamsters and mice after prolonged in vitro cultivation has been reported $(15,16)$. The loss of infectivity has been associated with changes in the outer membrane protein OspB (15). Wilske et al. $(17,18)$ observed quantitative changes between OspA and OspB on the one band and OspC on the other band or loss of OspA and OspB in subcultured European isolates. To study the changes induced by environmental conditions and to separate any variants from a heterogeneous mixture, cloned cells are needed. Although strains can be cloned by limited dilution in liquid medium (13), a cloning procedure on a solid agar medium facilitates purification and selection of variants and spontaneous mutants. However, so far, there are only two reports describing discrete colonies on a solid medium $(19,20)$.

In this chapter, we focused on the following questions: 1) Is it possible to leave out rabbit serum from the BSKII medium without loss of optimal growth. 2) What is the sensitivity of our previously used method to isolate $B$. burgdorferi from Ixodes ricinus using BSKII with the addition of neomycin, sulphamethoxazole and trimethoprim (BSKII-NST) (21). 3) Is it possible to obtain discrete colonies by simply solidifying BSKII. 4) Does repeated subculturing of $B$. burgdorferi cause changes in protein profiles, reactivity with monoclonal antibodies (MAbs), polymerase chain reaction (PCR) fingerprint, and infectivity for laboratory animals, and are possible changes related to the culture medium used. 


\section{MATERIALS AND METHODS}

\section{B. burgdorferi Strains}

The following five strains were used: the high-passage strain B31 (ATCC 35210), isolated from Ixodes scapularis (1); the high-passage human skin isolate PKo (kindly provided by B. Wilske, Max von Pettenkofer Institute, Munich, Germany) (17); and the low-passage strains M01, M02, and M03, isolated from Dutch I. ricinus ticks using BSKII-NST (21). After one passage $(P-1)$ in BSKII without antibiotics these latter three strains had been stored at $-70^{\circ} \mathrm{C}$. The strains $\mathrm{B} 31$ and $\mathrm{PKo}$ had also been stored at $-70^{\circ} \mathrm{C}$ after one passage in our laboratory.

\section{Liquid Culture Media and Conditions}

To evaluate the contribution of rabbit serum to the in-vitro growth of $B$. burgdorferi the BSKII medium (10) was compared with four BSKII modifications without rabbit serum (A through D). BSKII was prepared essentially as described by Barbour (10) (Table 1). The modifications A and B contained bovine serum albumin (BSA), fraction $V(735086$, Boehringer, Germany), and $C$ and D contained BSA of a lower grade (A4503, Sigma, USA). In the modifications $A$ and $C$, neopeptone was dissolved at room temperature, and in $B$ and $D$ it was dissolved in boiling water. Media were dispensed to $10-\mathrm{ml}$ screw-capped glass tubes, filled to $\pm 80 \%$ capacity and inoculated with $1 \mathrm{ml}$ of a suspension of $9 \times 10^{7}$ motile $B$. burgdorferi $\mathrm{B} 31$ cells per $\mathrm{ml}$ as determined in a counting chamber (Hawksley, UK) using a dark-field microscope. Tubes were incubated at $34^{\circ} \mathrm{C}$ and the number of viable spirochetes $/ \mathrm{ml}$ and the $\mathrm{pH}$ of each tube were determined every other day for up to 8 days after inoculation. To determine the sensitivity of the selective BSKIINST medium (BSKII with the addition of $100 \mu \mathrm{g} / \mathrm{ml}$ neomycin, $256 \mu \mathrm{g} / \mathrm{ml}$ sulphamethoxazole and $64 \mu \mathrm{g} / \mathrm{ml}$ trimethoprim) (21) the low-passage strain M02 was used. A culture containing $2 \times 10^{6}$ motile spirochetes $/ \mathrm{ml}$ as determined in a Hawksley counting chamber was diluted repeatedly to obtain eight suspensions containing spirochetal densities ranging from about 200 to less than 1 spirochete per $\mathrm{ml}$. One $\mathrm{ml}$ of each of these eight suspensions was inoculated in ten-fold into $10 \mathrm{ml}$ of BSKII-NST and incubated at $34^{\circ} \mathrm{C}$. The cultures were examined weekly for up to six weeks using dark-field microscopy. For the in-vitro passage experiments the low-passage strains M01, M02, M03, and the control strains B31 and PKo were passaged in BSKII as well as modification D i.e. the rabbit serum-free BSKII modification which showed the best growth. Fifty microlitres of each culture was transferred into $7 \mathrm{ml}$ of fresh medium weekly, up to forty weeks. 


\section{Solid Culture Media and Conditions}

Four solid media were investigated: BSKII with the addition of $1.25 \%$ agar, $1.5 \%$ agar, $1.25 \%$ agarose, or $1.5 \%$ agarose. The solid media were prepared as follows. Fraction I: to $700 \mathrm{ml}$ of glass-distilled water was added 100 $\mathrm{ml}$ of 10X CMRL 1066 without glutamine (Gibco 042-01540), $5 \mathrm{~g}$ neopeptone (Difco), $50 \mathrm{~g}$ bovine serum albumin, fraction $\mathrm{V}$ (Boehringer), $2 \mathrm{~g}$ TC yeastolate (Difco), $6 \mathrm{~g} \mathrm{HEPES}$ (Sigma), $5 \mathrm{~g}$ glucose, $0.7 \mathrm{~g} \mathrm{Na}$-citrate, $0.8 \mathrm{~g}$ $\mathrm{Na}$-pyruvate, and $0.4 \mathrm{~g} \mathrm{~N}$-acetyl-d-glucosamine (Sigma). This solution was sterilized by filtration through a $0.22 \mu \mathrm{m}$ nitrocellulose membrane (Millipore). Fraction II: either $16 \mathrm{~g}$ or $19 \mathrm{~g}$ agar (Difco), or $16 \mathrm{~g}$ or $19 \mathrm{~g}$ agarose (162-0015, Bio-Rad) was dissolved in $400 \mathrm{ml}$ boiling glass-distilled water and then autoclaved. The final medium was made in a laminar flow hood. One hundred $\mathrm{ml}$ of fraction $\mathrm{I}, 38 \mathrm{ml}$ of fraction $\mathrm{Il}$ and $10 \mathrm{ml}$ of rabbit serum, which had been warmed to $50^{\circ} \mathrm{C}$ in a water bath, were thoroughly mixed and dispensed into Petri dishes. To evaluate the five media the strains B31,

Table 1. Formulation of BSKIIa.

1. Use detergent-cleaned glassware which has been rinsed thoroughly with glass-distilled water and then autoclaved

2. Add $900 \mathrm{ml}$ of glass-distilled water to $100 \mathrm{ml}$ of $10 \times$ CMRL 1066 without glutamine (Gibco, 330-1540)

3. Dissolve in the $1 \times C M R L$ using a magnetic stirrer:

Neopeptone (Difco 0119-02-06)

TC yeastolate (Difco 5577-15-5)

HEPES buffer (Sigma H-3375)

Bovine serum albumin, Fraction V (Boehringer 735086)

Glucose

$5.0 \mathrm{~g}$

Na-citrate

$0.7 \mathrm{~g}$

Na-pyruvate

$0.8 \mathrm{~g}$

Na-acetyl-d-glucosamine (Sigma A-8625)

$0.4 \mathrm{~g}$

$\mathrm{Na}$-carbonate

4. Adjust $\mathrm{pH}$ with $1 \mathrm{~N} \mathrm{NaOH}$

5. Sterilize by filtration with air pressure (Millipore, $0.22 \mu \mathrm{m}$ nitrocellulose)

6. Add to sterile medium:

$7 \%$ solution of autoclaved gelatin (UCB 1381)

$200 \mathrm{ml}$

heat-inactivated "trace hemolyzed" rabbit serum (Gibco 037-6120)

7. Dispense to $10 \mathrm{ml}$ screw-capped glass tubes. Fill tubes to $80 \%$ capacity

8. Store at $-20^{\circ} \mathrm{C}$ until use

a BSKII was prepared essentially as described by Barbour (9). 
PKo and the low-passage strain M02 were used. Spirochetes, grown in liquid BSKII medium, were counted in a Hawksley counting chamber. Each solid medium was spot-inoculated in four-fold with $0.01 \mathrm{ml}$ of Borrelia suspensions of $10^{3}$ to $10^{7}$ organisms per $\mathrm{ml}$. Inoculation was done immediately after the medium had become solid. The cultures were incubated at $34^{\circ} \mathrm{C}$ either in a GasPak jar using an anaerobic catalyst or in a candle jar. After two weeks of inoculation the dishes were examined.

\section{Protein Electrophoresis and Western Immunoblotting}

Whole-cell sonicates of the culture passages P-2 and P-41 of the B31, PKo, M01, M02 and M03 strains were prepared as described by Craft et al. (3). The protein concentrations were determined by the Bio-Rad protein assay (Bio-Rad Laboratories, Germany). Sodium dodecyl-sulphate (SDS)-polyacrylamide gel electrophoresis (SDS-PAGE) was performed essentially as described by Laemmli (22). The separation gel contained $11 \%$ acrylamide and the stacking gel $4 \%$. Electrophoresis was performed on $0.5 \mathrm{~mm}$ gels, using $5 \mu \mathrm{g}$ of protein per lane. Low molecular mass standards (Pharmacia, Sweden) were run with each gel. Gels were either stained with Coomassie blue (Merck, Germany) or used for blotting. Protein transfer was performed at $0.8 \mathrm{~mA} / \mathrm{cm}^{2}$ for $1 \mathrm{~h}$ according to the method of Towbin et al. (23). The monoclonal antibodies H9724 (Symbicom, Sweden) directed against flagella (24), and H5332 and H3TS (Symbicom) directed against OspA $(25,26)$ were diluted 1:50, and H6831 (Symbicom), directed against OspB (27) was diluted 1:10. Alkaline phosphatase-tagged anti-mouse IgG (A1902 Sigma, USA) was diluted 1:600. Dimethylformamide buffer containing $165 \mu \mathrm{g} / \mathrm{ml}$ bromo-chloro-indolyl-phosphate (Sigma) and $330 \mu \mathrm{g} / \mathrm{ml}$ nitro blue tetrazolium (Sigma) was used as substrate.

\section{DNA Isolation}

Spirochetes from the passages $\mathrm{P}-2, \mathrm{P}-11, \mathrm{P}-21, \mathrm{P}-31$ and $\mathrm{P}-41$ were grown in BSKII for four weeks. Genomic DNA was isolated as follows: cultures were centrifuged and the cells were resuspended in $250 \mu \mathrm{l} \mathrm{STET}$ buffer (233 mM sucrose, $50 \mathrm{mM}$ Tris-HCl pH 8.0, $20 \mathrm{mM}$ EDTA, 5\% Triton X-100). Lysozyme was added to a final concentration of $1.7 \mathrm{mg} / \mathrm{ml}$. The suspension was incubated at room temperature for $5 \mathrm{~min}$., heated at $100^{\circ} \mathrm{C}$ for $1 \mathrm{~min}$. and put on ice for another $2 \mathrm{~min}$. In succession $0.3 \%$ sodium dodecyl-sulphate and $0.5 \mathrm{mg} / \mathrm{ml}$ proteinase $\mathrm{K}$ were added to the solution, which was then incubated at $55^{\circ} \mathrm{C}$ for $2 \mathrm{~h}$. Following extraction with phenol, $0.03 \mathrm{mg} / \mathrm{ml}$ RNase $A$ was added and the mixture was incubated at $37^{\circ} \mathrm{C}$ for $20 \mathrm{~min}$. The solution was extracted successively with phenol/chloroform/isoamylalcohol (25:24:1) and chloroform/isoamylalcohol (24:1). The DNA was precipitated overnight and resuspended in $100 \mu \mathrm{l}$ of distilled water. An aliquot was electrophoresed in an $1 \%$ agarose gel containing $0.1 \mu \mathrm{g} / \mathrm{ml}$ ethidiumbromide to estimate the DNA yield and verify DNA integrity. 


\section{PCR fingerprinting}

Random amplified polymorphic DNA (RAPD) PCR fingerprinting of spirochetal DNA (50 ng) was performed in a $50 \mu$ reaction volume containing $75 \mathrm{mM}$ Tris- $\mathrm{HCl}[\mathrm{pH} 9.0], 2.5 \mathrm{mM} \mathrm{MgCl}, 20 \mathrm{mM}\left(\mathrm{NH}_{4}\right)_{2} \mathrm{SO}_{4}, 0.01 \%$ Tween-20, 0.2mM dNTPs each, 50 pmol of primer D8635 (5'-GAGCGGCCAAAGGGAGCAGAC-3') and $0.2 \mathrm{U}$ of Taq DNA polymerase (Thermoperfectplus DNA, The Netherlands). A negative control, consisting of the same reaction mixture but without template DNA, was included in each reaction. A Perkin-Elmer thermal cycler was used for amplification running one of 3 programmes. The cycling program when using 10-NT consisted of 4 cycles of $94^{\circ} \mathrm{C}$ for $5 \mathrm{~min} ., 40^{\circ} \mathrm{C}$ for $5 \mathrm{~min}$., $72^{\circ} \mathrm{C}$ for $5 \mathrm{~min}$. (low stringency amplification), 30 cycles of $94^{\circ} \mathrm{C}$ for 1 min., $55^{\circ} \mathrm{C}$ for $1 \mathrm{~min} ., 72^{\circ} \mathrm{C}$ for $2 \mathrm{~min}$. (high stringency amplification), and final incubation at $72^{\circ} \mathrm{C}$ for $10 \mathrm{~min}$. (28). Amplified DNA $(5 \mu \mathrm{l})$ was separated by electrophoresis in $1.5 \%$ agarose gels and visualized by ethidium bromide staining $(0.1 \mu \mathrm{g} / \mathrm{ml})$. A molecular size marker (100 bp ladder); Pharmacia, The Netherlands) was used for reference. Gels were photographed and banding patterns were interpreted by visual inspection.

\section{Animal Inoculation}

Each of the passages P-2 and P-41 of the strains B31, PKo, M01, M02 and M03 were inoculated into five, 3-weeks-old, specific-pathogen-free (SPF) Lewis/M rats. The animals were obtained from the Centralized Experimental Animal Facilities of the University of Limburg and were housed in groups of five animals with free access to food and water. Spirochetes were washed three times in phosphate buffered saline. Each animal was inoculated intraperitoneally with $0.1 \mathrm{ml}$ of a suspension of about $10^{6}$ spirochetes $/ \mathrm{ml}$ as determined in a Hawksley counting chamber. The extremities of the animals were inspected weekly for manifestations of arthritis. Thirty days post inoculation the animals were killed with carbon dioxide gas and exsanguinated by cardiocentesis. After disinfection of the skin with $96 \%$ ethyl alcohol the ears were removed, and the bladder + kidneys, spleen and brain were aseptically removed. Ears were cut into small pieces and inner organs were placed in a sterile mortar containing $1 \mathrm{ml}$ of BSKII-NST and ground with a pestle. The resulting tissue suspensions were inoculated into BSKII and BSKII-NST. After one weeks incubation at $34^{\circ} \mathrm{C} 0.5 \mathrm{ml}$ of each BSKII-NST culture was transferred to BSKII medium. Weekly, for up to six weeks, the tubes were examined by means of dark-field microscopy. 


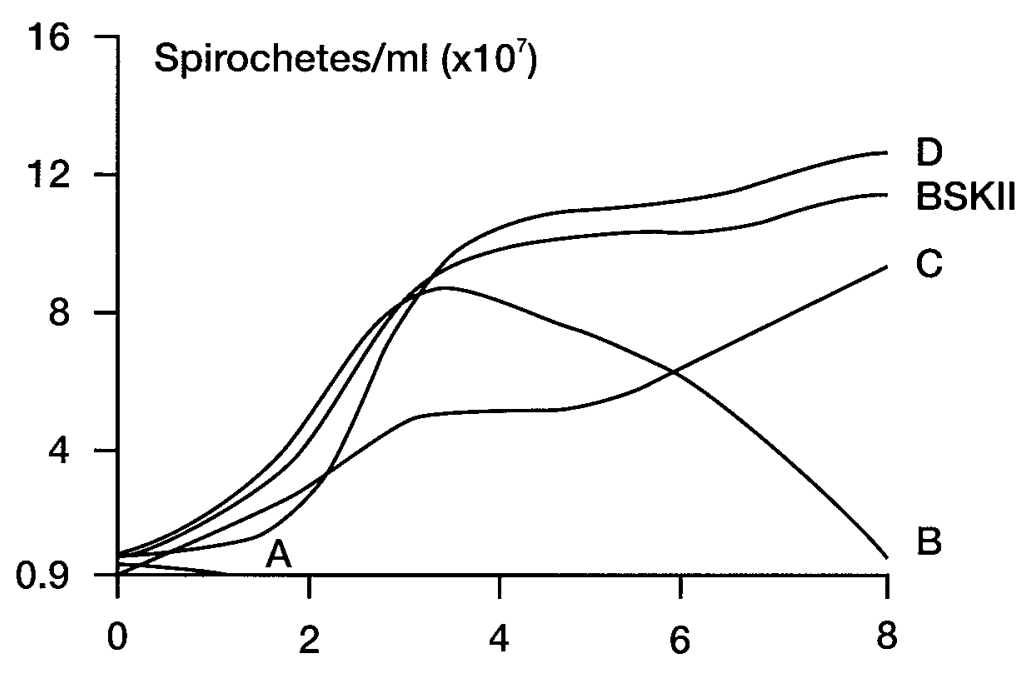

Days after inoculation of spirochetes

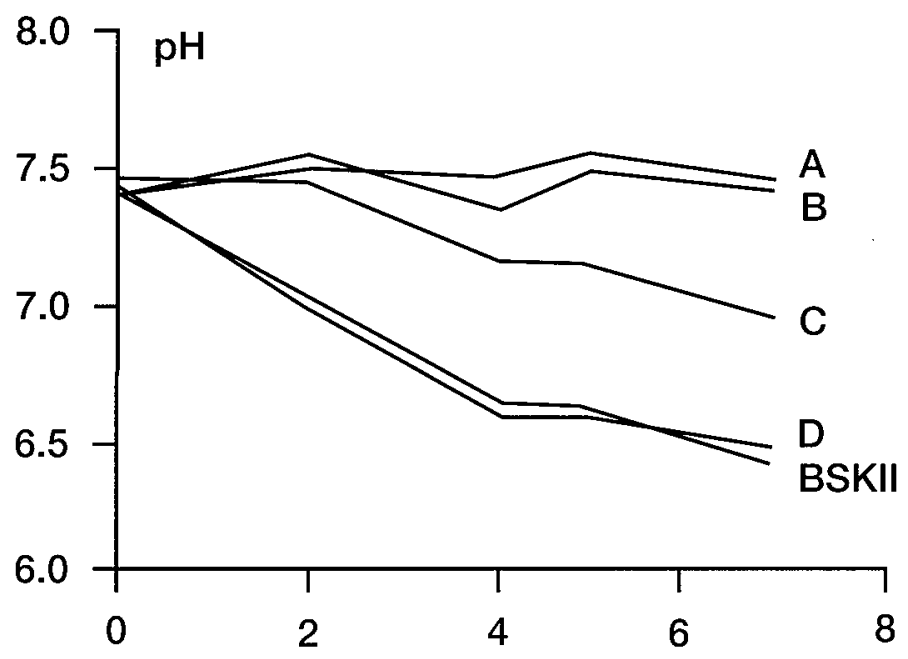

Days after inoculation of spirochetes

Figure 1. Comparison of four modifications of BSKII without rabbit serum for the cultivation of Borrelia burgdorferi. Modifications A and B contain high-grade bovine serum albumin; neopeptone was dissolved in cool and in boiling water, respectively. Modifications $\mathrm{C}$ and $\mathrm{D}$ contain crude bovine serum albumin; neopeptone was dissolved in cool and boiling water, respectively. Upper graph. Growth curves after inoculation of $1 \mathrm{ml}$ of $9 \times 10^{7}$ spirochetes per $\mathrm{ml}$ into $8 \mathrm{ml}$ of medium. Lower graph. $\mathrm{pH}$ of medium during seven days post inoculation. 


\section{RESULTS}

\section{Growth of B. burgdorferi in BSKII with and without Rabbit Serum}

Two of the four BSKII modifications without rabbit serum (C and D), i.e. the media containing low-grade BSA, supported the growth of $B$. burgdorferi B31 up to eight days after inoculation (Figure 1A). The growth stimulating capacity of modification $D$, in which the neopeptone was dissolved in boiling water, was at least as good as that of the complete BSKII. However, growth in modification $\mathrm{C}$, in which the neopeptone was dissolved at room temperature, was slower than that in the complete BSKII. The growth stimulating effect of dissolving neopeptone in boiling water was also observed in the two modifications containing high-grade BSA: whereas modification A (neopeptone dissolved at room temperature) showed no growth at all, modification $B$ (neopeptone dissolved in boiling water) initially, during the first three days after inoculation, stimulated the growth of $B$. burgdorferi. However, the spirochetes in this medium were less motile, less refractile and longer (30-40 $\mu \mathrm{m})$ than in the modification C, D and in BSKII, in which the spirochetes were uniformly motile and refractile, and showed lengths of 10-30 $\mu \mathrm{m}$. The increase in the number of motile spirochetes per $\mathrm{ml}$ was inversely proportional to the $\mathrm{pH}$ of each medium (Figure 1B).

Table 2. Recovery rates of Borrelia burgdorferi from different inocula in BSKII-NSTa during six weeks post inoculation.

\begin{tabular}{lcccccc}
\hline $\begin{array}{l}\text { Inoculumb } \\
\text { (spirochetes } \\
\text { per ml) }\end{array}$ & \multicolumn{5}{c}{ Tubes $(\mathrm{n}=10)$ showing motile spirochetes after } \\
\cline { 2 - 7 } & week 1 & week 2 & week 3 & week 4 & week 5 & week 6 \\
\hline 20 & - & $100 \%$ & $100 \%$ & $100 \%$ & $100 \%$ & $100 \%$ \\
10 & - & $100 \%$ & $100 \%$ & $100 \%$ & $100 \%$ & $100 \%$ \\
5 & - & $80 \%$ & $100 \%$ & $100 \%$ & $100 \%$ & $100 \%$ \\
2.5 & - & $60 \%$ & $100 \%$ & $100 \%$ & $100 \%$ & $100 \%$ \\
1.3 & - & $60 \%$ & $80 \%$ & $90 \%$ & $70 \%$ & $50 \%$ \\
0.6 & - & $50 \%$ & $80 \%$ & $80 \%$ & $70 \%$ & $30 \%$ \\
0.3 & - & $10 \%$ & $40 \%$ & $40 \%$ & - & - \\
0.1 & - & - & $10 \%$ & $20 \%$ & - & - \\
\hline
\end{tabular}

${ }^{a}$ BSKIl with the addition of neomycin $(100 \mu \mathrm{g} / \mathrm{ml})$, sulphamethoxazole $(256 \mu \mathrm{g} / \mathrm{ml})$ and trimethoprim $(64 \mu \mathrm{g} / \mathrm{ml})$.

b Inoculum calculated from diluting a suspension of $2 \times 10^{6}$ spirochetes $/ \mathrm{ml}$. 


\section{Sensitivity of the Selective BSKII-NST Medium}

The recovery rates of different inocula of $B$. burgdorferi in BSKII-NST during six weeks after inoculation are presented in Table 2. In all ten tubes inoculated with 2.5 spirochetes $/ \mathrm{ml}$ motile spirochetes were observed between the third and the sixth week post inoculation. With the inoculum of 1.3 spirochetes $/ \mathrm{ml}$ nine out of ten tubes yielded motile spirochetes in the fourth week after inoculation. However, after the fourth week all cultures initially containing $\leq 1.3$ spirochetes $/ \mathrm{ml}$ showed an decrease in the number of tubes yielding motile spirochetes.

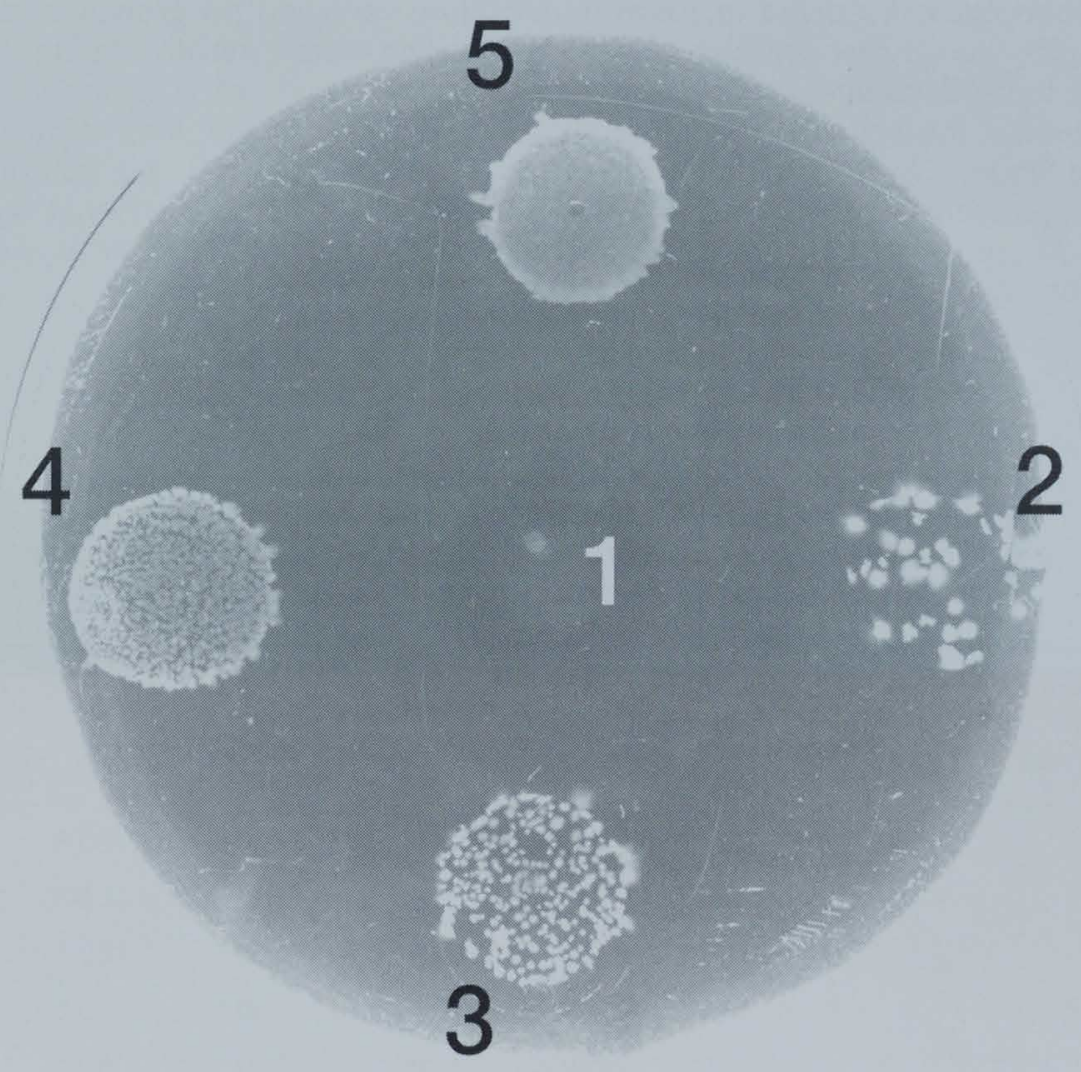

Figure 2. Growth of Borrelia burgdorferistrain M02 on BSKII, solidified with $1.25 \%$ agarose, after 2 weeks of incubation at $34^{\circ} \mathrm{C}$ in a GasPak jar using an anaerobic catalyst. The spots 1 to 5 were inoculated with $0.01 \mathrm{ml}$ of suspensions containing approximately $10^{3}$ to $10^{7}$ spirochetes per $\mathrm{ml}$, respectively. On spots 1 to 3 two different colony types can be distinguished: small, smooth colonies with well defined edges, and larger, diffuse, rough colonies. 


\section{Growth of B. burgdorferi on Solidified BSKII}

Two of the four solid media i.e. the media containing $1.25 \%$ agar or $1.5 \%$ agar, did not show any systematic growth pattern of the strains B31, PKo, and M02 after two weeks of incubation, neither in the anaerobic GasPak jar nor in the candle jar. $B$. burgdorferigrew in swarming patches on these media or as a lawn with spirochetes penetrating into the agar, but no discrete colonies were observed. The other two media, containing $1.25 \%$ or $1.5 \%$ agarose, supported the growth of discrete colonies, both after incubation in the GasPak jar and in the candle jar. However, colony numbers, size, and morphology differed depending on the concentration of agarose and the type of jar used. The use of $1.5 \%$ agarose resulted in lower numbers and smaller size of colonies, and incubation in a candle jar resulted in more swarming colonies. Considering the rates of recovery, formation of individual colonies and colony diameter, the best results were obtained with BSKII containing $1.25 \%$ agarose, incubated in a GasPak jar. In general, using this combination the following two types of colonies were observed: small $(0.3$ to $1 \mathrm{~mm}$ ), round, smooth colonies with a raised centre and well defined edges, which did not penetrate into the agar, and larger ( 1 to $3 \mathrm{~mm}$ ), diffuse, rough colonies, penetrating into the agar (Figure 2). The isolates differed in the colony types observed. Whereas the strains B31 and M02 showed both colony types in approximately equal numbers, strain PKo almost exclusively produced the small colony type. Although colonies were visible with the naked eye, a dissecting microscope was necessary for counting and determination of colony morphology. Using spot inoculation with $0.01 \mathrm{ml}$ of spirochetal suspension per spot culture dilutions containing $10^{3}$ to $10^{5}$ organisms $/ \mathrm{ml}$ were most appropriate. At higher spirochete concentrations the number of colonies could not be accurately determined as they tended to overlap and form lawns (Figure 2). With strain B31 the number of colonies observed on a spot correlated approximately with the calculated number of spirochetes inoculated (Figure 2), but with the other two strains the numbers of colonies were considerably lower than the calculated numbers of spirochetes in the inocula.

\section{Serial Cultivation and Protein Profiles, MAb Reactivity and PCR Fingerprints}

The strains B31, PKo, M01, M02 and M03 were all successfully passaged forty times in the complete as well as the rabbit serum-free BSKII medium. As presented in Figure 3 . the five strains were heterogeneous, especially with regard to OspA and OspB profiles, but no differences could be observed in the Coomassie blue-stained SDS-PAGE profiles before and after forty passages, neither in BSKII nor in the rabbit serum-free BSKII. MAb reactivities also did not show changes as a result of repeated subculturing: B31 and M02, which produced an OspA at $31 \mathrm{kDa}$ and an OspB at $34 \mathrm{kDa}$, reacted with the MAbs H9724 (anti-flagella), H5332 and H3TS (anti-OspA) and $\mathrm{H} 6831$ (anti-OspB); M01 and M03, which produced a single protein at $33 \mathrm{kDa}$, were reactive with $\mathrm{H} 9724$ and $\mathrm{H} 5332$; and $\mathrm{PKo}$, which showed an OspA at $33 \mathrm{kDa}$ and an OspB at $35 \mathrm{kDa}$, only reacted with H9724. RAPD 


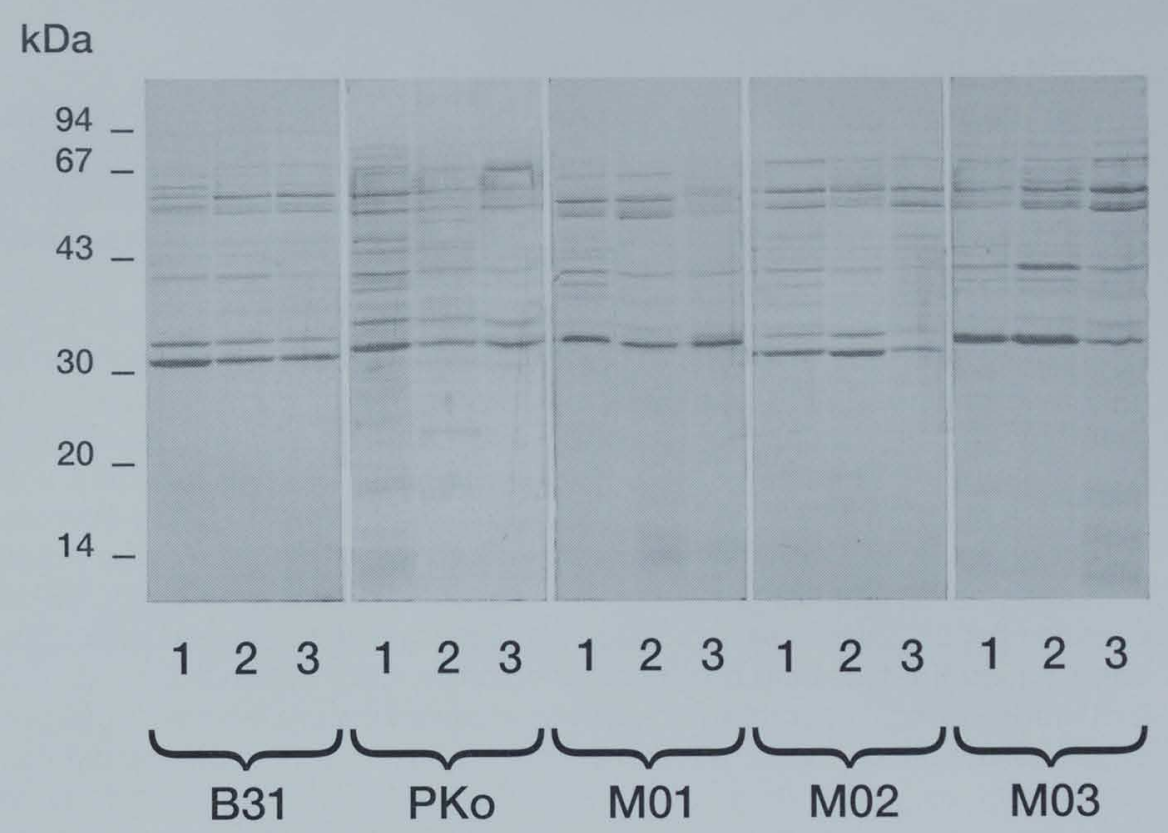

Figure 3. SDS-PAGE banding pattern of 5 Borrelia burgdorferi strains before the first passage (1) and after 40 passages in BSKII (2), and after 40 passages in rabbit serum-free BSKII (3). Coomassie-blue staining.

genotyping of the five strains before and after forty times in vitro cultivation (Figure 4) was in accordance with the findings with SDS-PAGE, Coomassie-blue staining and MAb reactivity: heterogeneity was seen among the strains but differences between the P-2 and P-41 passages were not observed.

\section{Serial Cultivation and Infectivity}

Inoculation of the culture passages P-2 of the strains M01, M02, and M03 caused infections in Lewis rats detectable by re-isolation of spirochetes from one or more of the tissues tested (Table 3 ). The spleen was found to be most often positive (9/11), followed by the bladder + kidneys (3/11) and the skin (1/11). No positive cultures were obtained from the brains. Inoculation with the culture passage P-41 of the strains M01, M02 and M03, and with the strains B31 and PKo after one and forty one passages in our laboratory, resulted in no re-isolation from any rat. Weekly and post mortem examination of the extremities of the animals did not reveal any signs or symptoms of arthritis, neither in animals from which B. burgdorferi was isolated nor in animals with negative cultures. Considering the two media used for re-isolation of spirochetes, BSKII was superior to BSKII-NST. Nine of the fifteen positive cultures were obtained in BSKII and five in BSKII-NST. One 
A

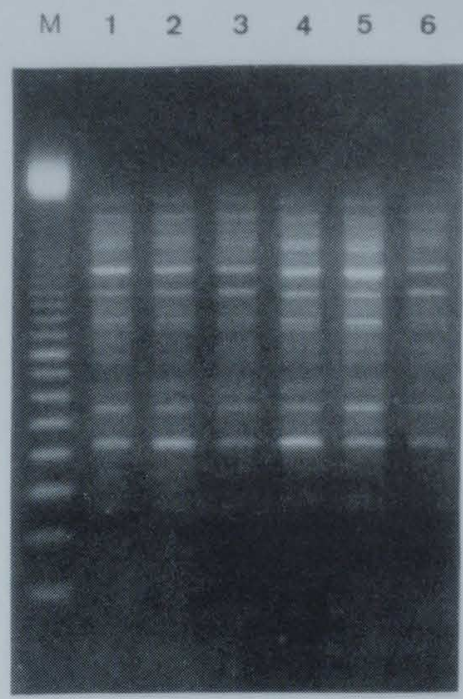

C

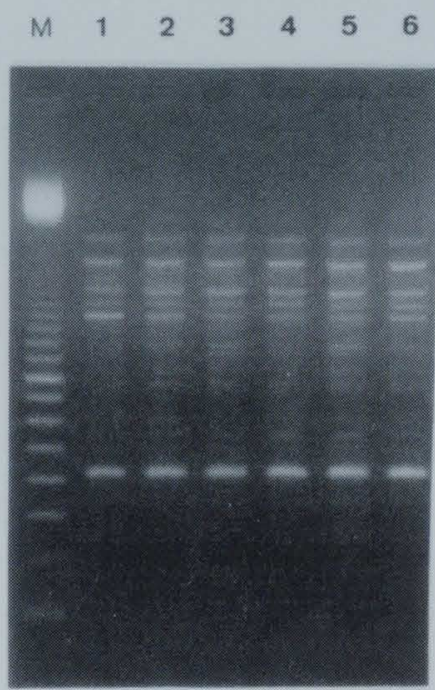

B

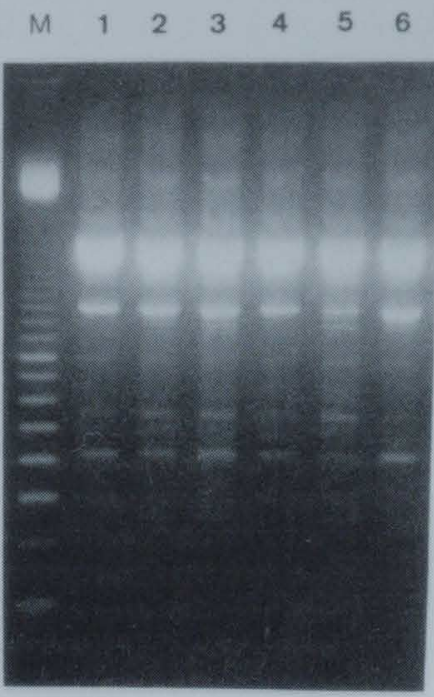

D

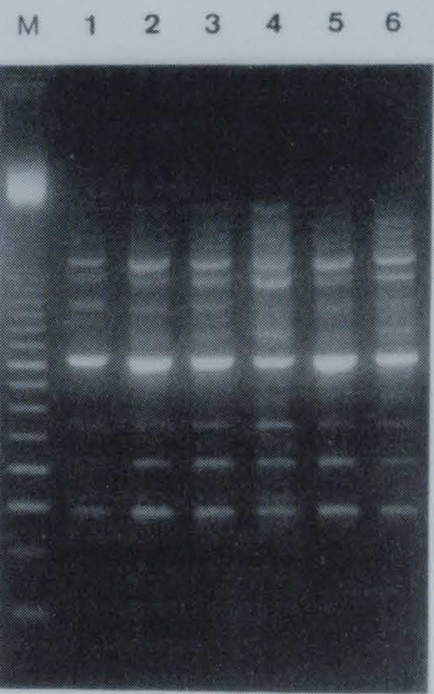

Figure 4. RAPD-PCR fingerprint analysis of Borrelia burgdorferi strains after the in-vitro passage (lane 1, P-2; lane 2, P-6; lane 3, P-11; lane 4, P-21; lane 5, P-31; lane 6, P-41). M represents the molecular size marker (100 basepair ladder). Panel A, strain B31; panel B, strain PKo; panel C, strain M01; panel D, strain M02. 
of the five positive cultures in BSKII-NST was observed in the initial tube and all five after transferring the initial tubes to BSKII one week post inoculation. However, in BSKII-NST the contamination rate $(8 / 600)$ was considerably lower than in BSKII (34/600).

\section{DISCUSSION}

As far as we know Borrelia has not been found proliferating in a natural environment outside a vector or a host animal. It is not surprising then that this host-associated organism requires complex artificial culture media. Although the BSKII formulation approaches the goal of a fully defined medium, it still contains rabbit serum. This undefined substrate is thought to supply the long-chain fatty acids required that are incorporated unaltered into the Borrelia lipids $(14,29)$. BSA also contains long-chain fatty acids (14). With regard to the two BSA preparations used in this study we found that the concentration of free fatty acids in the Sigma preparation was about three times that in the Boehringer preparation. Although we did not measure the free fatty acid concentration in the rabbit serum used, from the growth curves obtained with the four modifications without rabbit serum (Figure 1A) it may be concluded that the growth-enhancing properties of the BSKII medium depends, at least in part, on the concentration of the fatty acids in the BSA preparation used. The effect of BSA on the growth-enhancing prop-

Table 3. Effect of in-vitro cultivation of Borrelia burgdorferi on the infectivity in Lewis ratsa.

\begin{tabular}{|c|c|c|c|c|c|c|}
\hline \multirow{2}{*}{ Strain } & \multirow{2}{*}{ Passage } & \multicolumn{4}{|c|}{ No. of tissues infected } & \multirow{2}{*}{$\begin{array}{l}\text { No- of rats } \\
\text { infected }\end{array}$} \\
\hline & & Brain & $\begin{array}{l}\text { Bladder/ } \\
\text { kidney }\end{array}$ & Spleen & Skin & \\
\hline M01 & P-2 & - & 1 & 3 & - & 4 \\
\hline M01 & $P-41$ & - & - & - & - & - \\
\hline M02 & $P-2$ & - & - & 4 & - & 4 \\
\hline M02 & $P-41$ & - & - & - & - & - \\
\hline M03 & P-2 & - & 2 & 2 & 1 & 3 \\
\hline M03 & $P-41$ & - & - & - & - & - \\
\hline B31 & $\mathrm{P}-2$ & - & - & - & - & - \\
\hline B31 & $P-41$ & - & - & - & - & - \\
\hline PKo & $P-2$ & - & - & - & - & - \\
\hline PKo & $P-41$ & - & - & - & - & - \\
\hline
\end{tabular}

a Five rats were inoculated intraperitoneally with each passage. 
erties of BSKII, even when rabbit serum is added, has also been demonstrated by Callister et al. (30). These authors found that the minimum detection level for $B$. burgdorferivaried from $10^{5}$ to $<2$ spirochetes per $\mathrm{ml}$ when different BSA preparations were used. However, as is demonstrated by the growth curves of strain B31 in the modifications $A$ and $C$, and $B$ and $D$, in which the neopeptone was dissolved in cool water and in boiling water, respectively, the growth-enhancing properties of rabbit serum cannot fully be replaced by a lower grade BSA preparation alone. Obviously, boiling the neopeptone is necessary in order to liberate either free fatty acids or other factors which are otherwise be provided by rabbit serum. Our conclusion that the rabbit serum in BSKII can be omitted provided that a crude BSA preparation is used and that neopeptone is dissolved in boiling water, may be criticized, first because of the use of the laboratory adapted strain B31, and second because we did not determine the minimum inoculum of $B$. burgdorferi needed for detection. Nevertheless, based on our own experience and that of others $(10,31)$ with a rabbit serum-free medium we believe that this medium, is a good alternative to the complete BSKII. This is particularly true in light of our observations that some strains could only be isolated in the rabbit serum-free medium whereas others were only recovered from the complete BSKII. These findings led us to decide to use both media in parallel when $B$. burgdorferi should be isolated from human, animal or tick specimens.

Evaluation of the selective BSKII-NST medium with a low-passage Dutch tick isolate showed that this medium supported the growth of approximately 2 spirochetes. Nevertheless, in a previous study in which we investigated tick specimens both by culturing in BSKII-NST and by immunofluorescent antibody assay we found the latter method, which inherently has a detection level of at most $10^{3}$ organisms per $\mathrm{ml}$, to be twice as sensitive as culture (21). A possible explanation for this discrepancy may be that there are differences in sensitivity among Borrelia strains to the antibiotics used. This explanation is supported by three observations. First, with an inoculum of $\leq 1.3$ spirochetes the number of positive tubes decreased after the fourth week post inoculation (Table 2). Second, the recovery rates from the organs of the experimentally infected Lewis rats were considerably higher when the initial cultures in BSKII-NST was passaged blindly into BSKII without antibiotics one week after inoculation. Third, although the contamination rate in BSKII-NST was considerably lower than in BSKII without antibiotics $(1 \%$ versus $6 \%)$ the recovery rate of $B$. burgdorferi from the organs of the experimentally infected rats in BSKII without antibiotics was about twice that of the recovery rate in BSKII-NST. Van Dam et al. (32) who used BSKII with the addition of gentamicin, sulphamethoxazole, trimethoprim, and amphotericin $B$ to isolate $B$. burgdorferi from ticks noticed that a strain, after initially showing growth, died after as short as 7 days of incubation in their selective medium. Johnson et al. (33) compared BSKII and BSKII with the addition of kanamycin and 5-fluorouracil and found a significantly higher recovery rate from ticks in the latter, but the contamination rate in their selective medium (12\%) still remained a problem. From these studies and from our observations it might be clear that the ideal selective medium for 
the isolation of $B$. burgdorferi has not yet been developed. Further work is needed to determine which antibiotics should be used and in which concentrations they should be added in order to obtain optimal recovery rates in combination with low contamination rates.

Our experiments to obtain discrete $B$. burgdorfericolonies on solidified BSKII demonstrate that this is indeed possible with agarose but not with agar, at least not with the agar concentrations used in this study. Kurtti et al. (19), who first described colonial growth of $B$. burgdorferi using BSKII with the addition of $1.3 \%$ agarose, incubated their plates in a candle jar. In our hands incubation in an anaerobic atmosphere using a GasPak jar was superior to the micro-aerophilic condition obtained with a candle jar. This observation is in agreement with the results of aerotolerance testing by Preac-Mursic et al. (20) from which they conclude that $B$. burgdorferi prefers an anaerobic atmosphere. These authors compared six solid media, and found that a BSKII modification in which $\mathrm{Na}$-thioglycolate was added and yeastolate, BSA and rabbit serum were replaced by horse serum and human plasma, yielded higher recovery rates and better and more divers colonies than all five other media tested, including BSKII. However, in light of the bacteriologist's goal to prepare fully defined media and the general tendency in laboratory practice to avoid the use of human body fluids in media and reagents, these results can hardly be called to be an advantage. Hence, further work is needed to optimize the solid BSKII medium using more defined substrates. The use of Na-thioglycolate, as proposed by Preac-Mursic et al. (20), may indeed be useful in that it reduces the redox potential in the medium. As demonstrated by our experiments with liquid BSKII (Figure 1A) the effects of dissolving the neopeptone in boiling water rather than cool water and the use of crude BSA preparations are also worthwhile to study.

It has been shown that changes or loss of major proteins of $B$. burgdorferi may be induced in the laboratory by repeated subculturing $(17,18,34,35)$ and several investigators have stressed the importance of this phenomenon when interpreting diagnostic tests for Lyme borreliosis $(15,18,35)$. However, as far as we know, it has not been demonstrated that whole-cell sonicates of different strains of $B$. burgdorferi significantly affect EIA and Western immunoblot results. This is even true of the recent findings that there exist different subspecies of $B$. burgdorferi, which differ in their OspA and OspB profiles, and which may be related to different manifestations of Lyme borreliosis $(32,36)$. In this study we did not observe any differences between low- and high-passage tick isolates, in their SDS-PAGE profiles, their MAb reactivities, and their genotypes as studied by RAPD-PCR. In common with other investigators, we did not use cloned initial cultures. Hence, a possible explanation for the observed changes after subculturing by others could be that in-vitro selection of certain variants had occurred in their inital populations.

Several investigators have reported that infectivity of $B$. burgdorferi for laboratory animals is lost upon prolonged in-vitro cultivation $(15,16)$. Schwan et al. (35), who described an I. dammini isolate which initially was infectious in mice and produced a protein at $34 \mathrm{kDa}$, but lost these characteristics after 10 to 15 in-vitro passages, have suggested that infectivity is associated 
with the presence of OspB. Subsequent studies have indicated that infectivity may be associated with plasmids other than those encoding for the OspA and OspB proteins $(15,37,38)$. Although we did not perform plasmid analysis our findings indicate that there may be no relation between the loss of infectivity and changes in outer membrane proteins. Moody et al. (39) have studied the effect of host species on the development of Lyme borreliosis. Rats, mice, Syrian hamsters and rabbits, which showed multisystem infection as determined by positive organ cultures after inoculation with a low-passage $B$. burgdorferi strain all developed arthritis and carditis. We did not observe any signs and symptoms of arthritis in the culture positive Lewis rats. This discrepancy may first be explained by the fact that Moody et al. (39) used 3-day-old rats whereas the rats in our study were three weeks at the time of inoculation. The effect of the host's age on its susceptibility to disease development has indeed been demonstrated (39). Using the same strain 3-day-old inoculated hamsters developed gross arthritis whereas 3-week-old hamsters did not even show histological abnormalities in the synovial tissue. A second explanation may be that we may have missed signs of inflammation induced by $B$. burgdorferi because we did not perform histology. A third explanation may be that the three lowpassage isolates used in this study were not pathogenic. Anderson et al. (40), have described an I. scapularis isolate which was re-isolated from the joints of 3-day-old Lewis rats but did not cause any signs of inflammation as determined by histological examination of synovial tissue. In contrast to the arthritogenic strain of Moody et al. (39), which produced OspA and OspB proteins at 31 and $34 \mathrm{kDa}$, this nonarthritogenic strain had aberrant OspA and OspB proteins of $32.5 \mathrm{kDa}$ and $35.5 \mathrm{kDa}$ as well as a prominent lowmolecular mass protein at $23.5 \mathrm{kDa}$, and could not be re-isolated from the livers or brains of the inoculated rats. Although the three low-passage isolates used in our experiment did not have this aberrant protein profile and we did not culture joints and livers it is interesting that the brains were the only organs always negative. From our animal experiment and from the literature we conclude that low-passage $B$. burgdorferi isolates induce infection in a wide range of laboratory animals but that disease is only induced with some strains and/or in the presence of some hitherto unknown host factors. The loss of infectivity or pathogenicity after repeated subculturing of $B$. burgdorferi cannot be explained by the loss of outer membrane proteins. 


\section{REFERENCES}

1. Burgdorfer W, Barbour AG, Hayes SF, Benach JL, Grunwaldt E, Davis JP. Lyme disease - a tick-borne spirochetosis? Science 1982; 216: 1317-1319.

2. Barbour AG. Laboratory aspects of Lyme borreliosis. Clinical Microbiology Reviews 1988; 1: 399-414.

3. Craft JE, Grodzicki RL, Steere AC. Antibody response in Lyme disease: evaluation of diagnostic tests. Journal of Infectious Diseases 1984; 149: 789-795.

4. Rose CD, Fawcett PT, Singsen BH, Dubbs SB, Doughty RA. Use of Western blot and enzyme-linked immunosorbent assays to assist in the diagnosis of Lyme disease. Pediatrics 1991; 88: 465-470.

5. Lane RS, Piesman J, Burgdorfer W. Lyme borreliosis: relation of its causative agent to its vectors and hosts in North America and Europe. Annual Review of Entomology 1991; 36: 587-609.

6. Rahn DW. Lyme disease: clinical manifestations, diagnosis, and treatment. Seminars in Arthritis and Rheumatism 1991; 20: 201-218.

7. de Boer R, Hovius KE, Nohlmans MKE, Gray JS. The woodmouse (Apodemus sylvaticus) as a reservoir of tick-transmitted spirochetes (Borrelia burgdorferi) in the Netherlands. Zentralblatt für Bakteriologie 1993; 279: 404-416.

8. Sambri V, Massaria F, Cevenini R, La-Placa M. In-vitro susceptibility of Borrelia burgdorferi and Borrelia hermsii to ten antimicrobial agents. Journal of Chemotherapy $1990 ; 2$ : 348-350.

9. Kramer MD, Simon MM, Schaible UE, Moter SE, Wallich R. Die Borrelia burgdorferi Infektion. II. Aspekte der Grundlagenforschung, neue Ansätze für Diagnostik und Therapie. Hautartzt 1991; 42: 63-71.

10. Barbour AG. Isolation and cultivation of Lyme disease spirochetes. Yale Journal of Biology and Medicine 1984; 57: 521-525.

11. Kelly R. Cultivation of Borrelia hermsii. Science 1971; 173: 443-444.

12. Stoenner HG, Dodd T, Larsen C. Antigenic variation of Borrelia hermsii. Journal of Experimental Medicine 1982; 156: 1297-1311.

13. Barbour AG, Burgdorfer W, Hayes SF, Peter O, Aeschlimann A. Isolation of a cultivable spirochete from Ixodes ricinus tic': $\mathrm{S}$ of Switzerland. Current Microbiology 1983; 8: 123-126.

14. Barbour AG, Hayes SF. Biology of Borrelie: iecies. Microbiological Reviews 1986; 50: 381-400.

15. Schwan TG, Burgdorfer W, Garon CF. Changes in infectivity and plasmid profile of the Lyme disease spirochete, Borrelia burgdorferi, as a result of in-vitro cultivation. Infection and Immunity 1988; 56: 1831-1836.

16. Johnson RC, Marek N, Kodner C. Infection of Syrian hamsters with Lyme disease spirochetes. Journal of Clinical Microbiology 1984; 20: 1099-1102.

17. Wilske B, Preac-Mursic V, Schierz G, Busch KV. Immunochemical and immunological analysis of European Borrelia burgdorferi strains. Zentralblatt für Bakteriologie, Mikrobiologie und Hygiene [A] 1986; 263: 92-102.

18. Wilske B, Preac-Mursic V, Schierz G, Kühbeck R, Barbour AG, Kramer M. Antigenic variation of Borrelia burgdorferi. Annals of the New YorkAcademy of Sciences 1988; 539: 126-143. 
19. Kurtti TJ, Munderloh UG, Johnson RC, Ahlstrand GG. Colony formation and morphology in Borrelia burgdorferi. Journal of Clinical Microbiology 1987; 25: 2054-2058.

20. Preac-Mursic V, Wilske B, Reinhardt S. Culture of Borrelia burgdorferi on six solid media. European Journal of Clinical Microbiology 1991; 10: 1076-1079.

21. Nohlmans MKE, de Boer R, van den Bogaard AEJM, Blaauw AAM, van Boven CPA. Voorkomen van Borrelia burgdorferi in Ixodes ricinus in Nederland. Nederlands Tijdschrift voor Geneeskunde 1990; 134: 1300-1303.

22. Laemmli UK. Cleavage of structural proteins during the assembly of the head of bacteriophage T4. Nature 1970; 227: 680-685.

23. Towbin H, Staehelin J, Gordon J. Electrophoretic transfer of proteins from polyacrylamide gels to nitrocellulose sheets: procedure and some applications. Proceedings of the National Academy of Sciences of the USA 1979; 76: 4350-4354.

24. Barbour AG, Hayes SF, Heiland RA, Schrumph ME, Tessier SL. A Borreliaspecific monoclonal antibody binds to a flagellar epitope. Infection and Immunity 1986 ; 52 : 549-554.

25. Barbour AG, Tessier SL, 10 $\mathrm{E}$ WJ. Lyme disease spirochetes and ixodid tick spirochetes share a comirion surface antigenic determinant defined by a monoclonal antibody. Infection and Immunity 1983; 41: 795-804.

26. Barbour AG, Heiland RA, Howe TR. Heterogeneity of major proteins in Lyme disease borreliae: a molecular analysis of North American and European isolates. Journal of Infectious Diseases 1985; 152: 478-484.

27. Barbour AG, Tessier SL, Hayes SF. Variations in major surface proteins of Lyme disease spirochetes. Infection and Immunity 1984; 45: 94-100.

28. Akopyanz N, Bukanov NO, Westblom TU, Kresovich S, Berg DE. DNA diversity among clinical isolates of Helicobacter pylori detected by PCR RAPD fingerprinting. Nucleic Acids Research 1992; 20: 5137-5142.

29. Johnson RC, Hyde F, Rumpel CM. Taxonomy of the Lyme disease spirochetes. Yale Journal of Biology and Medicine 1984; 57: 529-537.

30. Callister SM, Case KL, Agger WA, Schell RF, Johnson RC, Ellingson JLE. Effect of bovine serum albumin on the ability of Barbour-Stoenner-Kelly medium to detect Borrelia burgdorferi. Journal of Clinical Microbiology 1990; 28: 363-365.

31. Berger BW, Kaplan MH, Rothenberg IR, BarbourAG. Isolation and characterization of the Lyme disease spirochete from the skin of patients with erythema chronicum migrans. Journal of the American Academy of Dermatology 1985; 13: 444-449.

32. van Dam AP, Kuiper H, Vos K, Widjojokusumo A, de Jongh BM, Spanjaard L, Ramselaar ACP, Kramer MD, Dankert J. Different genospecies of Borrelia burgdorferi are associated with distinct clinical manifestations of Lyme borreliosis. Clinical Infectious Diseases 1993; 17: 708-717.

33. Johnson SE, Klein GC, Schmid GP, Bowen S, Feeley JC, Schulze T. Lyme disease: a selective medium for isolation of the suspected etiological agent, a spirochete. Journal of Clinical Microbiology 1984; 19: 81-82.

34. Karlsson M, Hovind-Haugen K, Svenungsson BO, Stiernstedt G. Cultivation and characterization of spirochetes from cerebrospinal fluid of patients with Lyme borreliosis. Journal of Clinical Microbiology 1990; 28: 473-479. 
35. Schwan TG, Burgdorfer W. Antigenic changes of Borrelia burgdorferi as a result of in vitro cultivation. Journal of Infectious Diseases 1987; 156: 852853.

36. Wilske B, Preac-Mursic V, Göbel UB, Graf B, Jauris S, Soutschek E, Schwab E, Zumstein G. An OspA serotyping system for Borrelia burgdorferi based on reactivity with monoclonal antibodies and OspA sequence analysis. Journal of Clinical Microbiology 1993; 31: 340-350.

37. BarbourAG. Plasmid analysis of Borrelia burgdorferi, the Lyme disease agent. Journal of Clinical Microbiology 1988; 26: 475-478.

38. Hyde FW, Johnson RC. Characterization of a circular plasmid from Borrelia burgdorferi, etiologic agent of Lyme disease. Journal of Clinical Microbiology 1988; 26: 2203-2205.

39. Moody KD, Barthold SW, Terwilliger GA. Lyme borreliosis in laboratory animals: effect of host species and in vitro passage of Borrelia burgdorferi. American Journal of Tropical Medicine and Hygiene 1990; 43: 87-92.

40. Anderson JF, Barthold SW, Magnarelli LA. Infectious but nonpathogenic isolate of Borrelia burgdorferi. Journal of Clinical Microbiology 1990; 28: 26932699. 


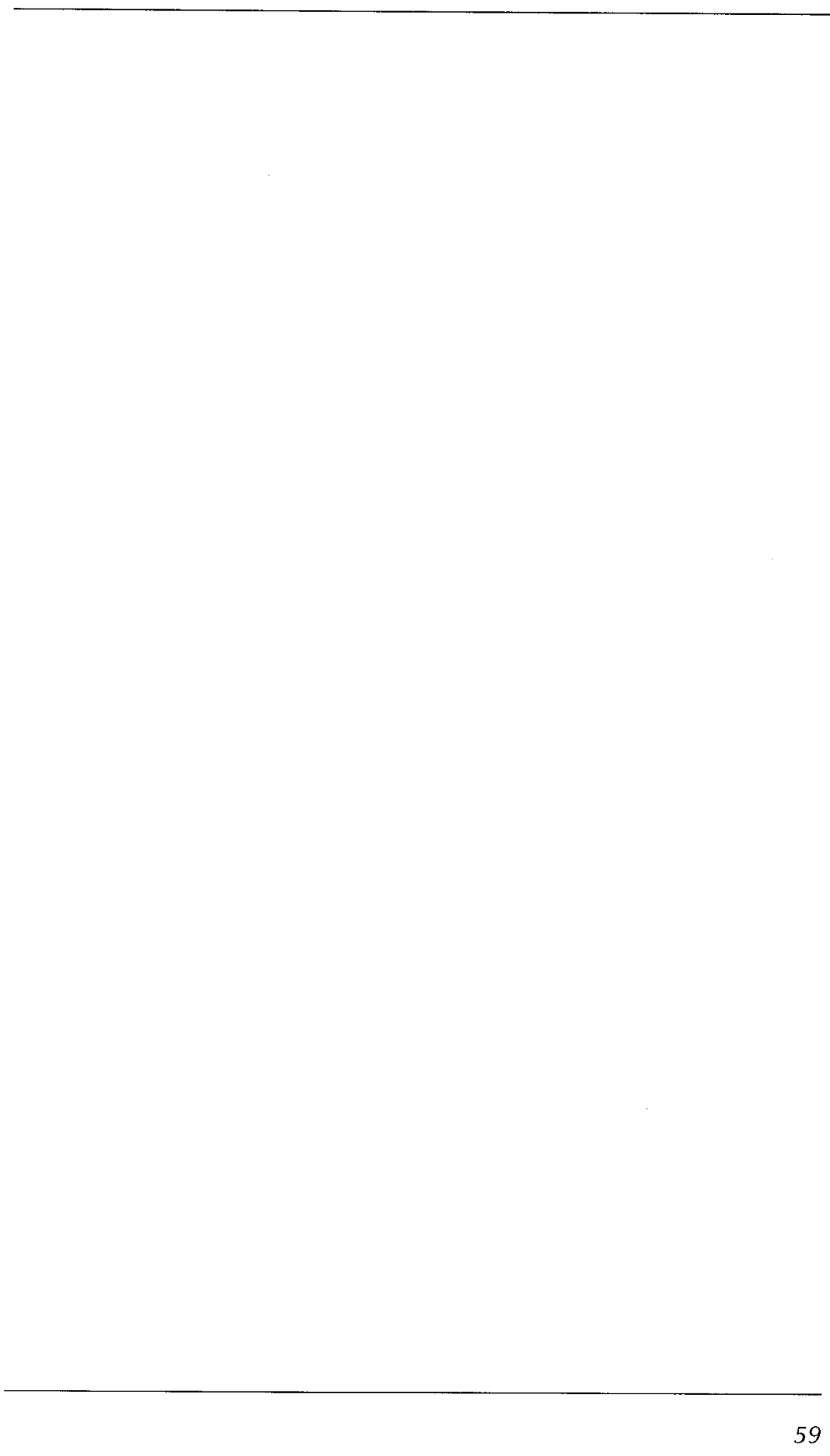




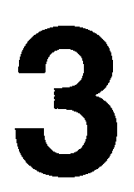

\section{OCCURRENCE OF BORRELIA BURGDORFERI IN IXODES RICINUS IN THE NETHERLANDS}

MKE Nohlmans ${ }^{1}, \mathrm{R}$ de Boer ${ }^{2}$, AEJM van den Bogaard', AAM Blaauw ${ }^{3}$, CPA van Boven ${ }^{1}$

1 Department of Medical Microbiology, State University of Limburg, Maastricht;

2 Department of Pure and Applied Ecology, University of Amsterdam, Amsterdam;

3 Department of Internal Medicine, Division of Rheumatology, University Hospital Maastricht, Maastricht, The Netherlands.

Reprinted by permission of the Nederlands Tijdschrift voor Geneeskunde 1990; 134 : 1300-1303. 


\section{OCCURRENCE OF BORRELIA BURGDORFERI IN IXODES RICINUS IN THE NETHERLANDS}

\section{ABSTRACT}

In a 1989 surveillance to study the infection rate of Ixodes ricinus ticks with Borrelia burgdorferi, a total of 1838 nymphal and adult Ixodes ricinus ticks were collected from 20 locations in The Netherlands. By means of a culture method using modified Barbour-Kelly-Stoenner medium nymphs were examined in pools of 4 and adults were examined individually. With 63 out of 75 isolates propagation and serological identification were possible. All of these 63 isolates were identified as Borrelia burgdorferi by means of an immunofluorescent antibody assay. In nymphs the minimal infection rate was $2.4 \%$. The rate of infection for adults was shown to be $14.3 \%$. These results are in agreement with the percentages found by other investigators in West-Europe. In all locations examined Ixodes ricinus were found to be infected with Borrelia burgdorferi, although the infection rate varied. The results indicate that the infection is widespread among ticks in The Netherlands and the potential risk of acquiring Lyme borreliosis after a tick bite is serious.

\section{INTRODUCTION}

Borrelia burgdorferi is the causative agent of Lyme borreliosis, a complex, multisystem disorder, which occurs in The Netherlands (1-10). The clinical course of the disease and symptoms have been described previously, (11) but its prevalence and incidence still remain largely unknown.

After the isolation of $B$. burgdorferifrom Ixodes scapularis (formerly known as (xodes dammini) by Burgdorfer in 1982, the common cause of a number of disorders was established and confirmed: the infection being transmitted by the bite of a tick infected with $B$. burgdorferi (12). The vectors are infected hard ticks, belonging to the Ixodes ricinus complex, to which belong, amongst others, I. scapularis and Ixodes pacificus in the USA, Ixodes persulcatus in Asia, and Ixodes ricinus in Europe (12). Although soft ticks and other hard ticks occur in The Netherlands, I. ricinus, known colloquially as the common or sheep tick, is the most well known and widespread (13). I. ricinus usually has a life cycle of two years, during which time larvae develop into adult ticks via a nymphal stage. At each stage, for a period of two to five days, the tick feeds once on the blood of the host. At each stage of development the ticks are active mainly between April and October, inclusive. Small animals, mainly rodents are the most common hosts for the larvae and nymphs and are also the most important reservoir of $B$. burg- 
dorferi. Birds, larger wild mammals, domestic animals and humans may become opportunist hosts $(15,16)$. Nymphs and adult ticks are mainly responsible for the transmission of Lyme borreliosis; transovarial transmission of the infection is extremely rare (17). There is evidence that the host becomes infected by the saliva of the tick, and that the chance of infection increases with the length of feeding time (18). It is not clear how often symptomatic Lyme disease follows the bite of an infected tick. In a summer camp in southern Germany, 41 people were infested with infected ticks, and 27 of them had developed antibodies to $B$. burgdorferi after 13 weeks; only one case of erythema migrans developed (19).

In order to gain more insight into the occurrence of Lyme borreliosis in The Netherlands, good documentation of patients with Lyme borreliosis and studies of the prevalence and incidence of seropositivity are important, along with investigation of the prevalence of infection of the 1 . ricinus population with B. burgdorferi.

Studies carried out in Switzerland, Germany, Austria and Sweden showed a variation of between 2 and $40 \%$ prevalence of infection. The object of this investigation was to determine the situation in The Netherlands.

\section{MATERIALS AND METHODS}

\section{Collection of Ticks}

Inspectors from the Veterinary Inspection Service collected ticks from 20 locations in The Netherlands by means of "flagging", between June and September, inclusive, in 1989. Using this method, a white flannel cloth is dragged over low vegetation. Samples were taken from verges, footpaths and parking places in and around woodlands, dunes and heathlands, where people were exposed to the risk of infestation. Bacteriological investigation of adult ticks and nymphs belonging to the species I. ricinus was carried out. Identification and selection of the ticks was done macroscopically and they were kept alive in a moist environment at between 18 and $22^{\circ} \mathrm{C}$, until the time of investigation.

\section{Bacteriology}

The ticks were disinfected in $96 \%$ ethyl alcohol with $4.8 \%$ acetone for 5 to 10 seconds and then dabbed dry with sterile gauze. Groups of four nymphs, and individual adult ticks, were then homogenized in $50 \mu \mathrm{l}$ of culture medium. Tubes containing $7 \mathrm{ml}$ Barbour-Kelly-Stoenner medium (26), to which had been added neomycin $(100 \mu \mathrm{g} / \mathrm{ml})$, sulphamethoxazole $(256 \mu \mathrm{l} / \mathrm{ml})$ and trimethoprim $(64 \mu \mathrm{g} / \mathrm{ml})$, were then inoculated with this homogenate and incubated for 10 weeks at $34^{\circ} \mathrm{C}$. Weekly, from the second week onwards, each tube was examined for the presence of spirochetes, by means of darkfield microscopy. If contamination with moulds or yeasts was detected, 50 $\mu$ amphotericin B $(5 \mathrm{mg} / \mathrm{ml})$ was added. If the typical "mobile" shapes of $B$. burgdorferi were observed, re-inoculation into the medium without additi- 


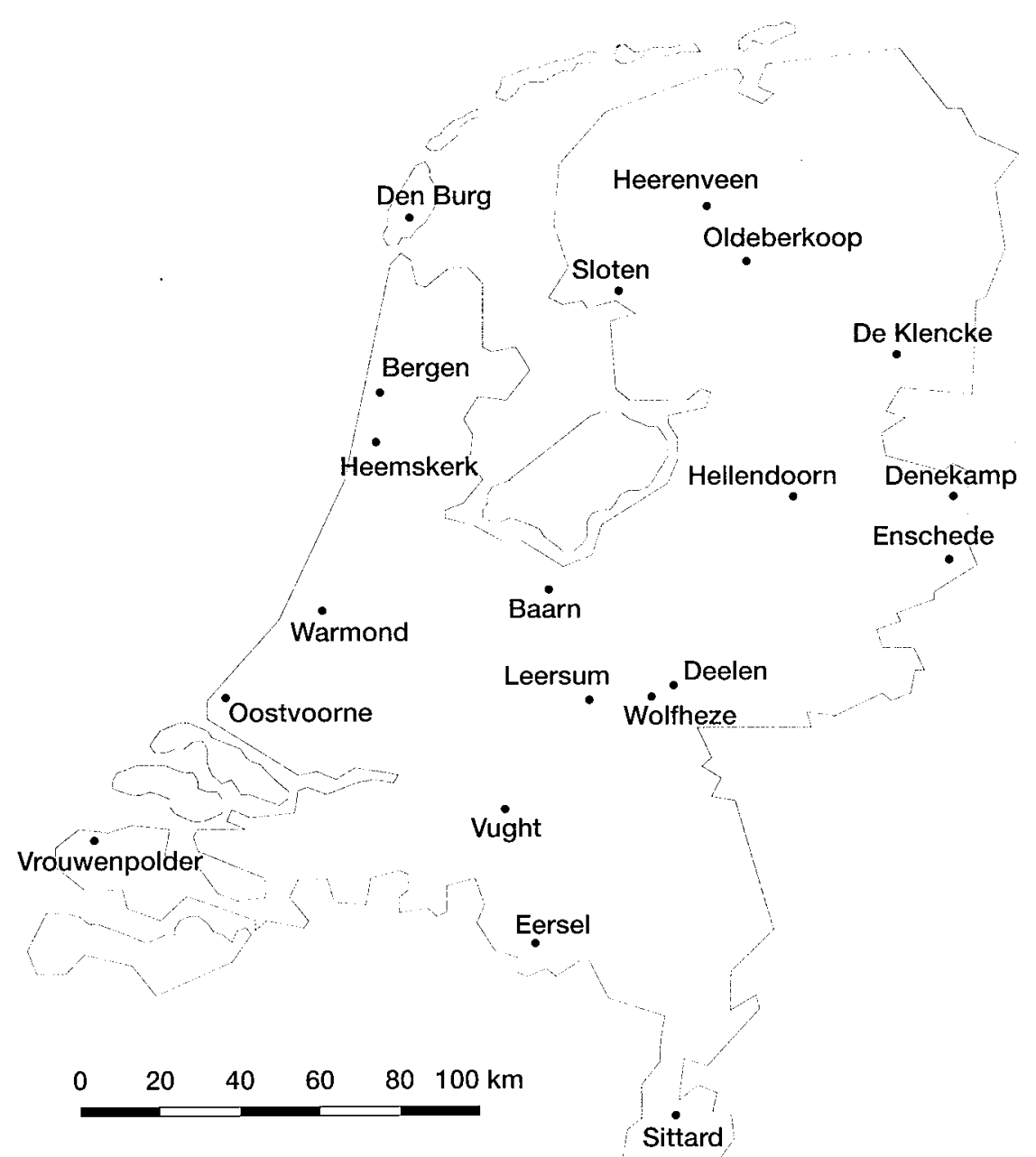

Figure 1. Geographic situation of the 20 locations in The Netherlands where /xodes ricinus ticks were collected. 
ves took place. Isolates which could be processed further, were identified with a modified indirect immunofluorescent antibody assay (IFA) as described by Wilske (27). For this purpose, serum from a patient with Lyme borreliosis (IgG titre in IFA: >1024) was used as the primary antibody, and an antihuman IgG conjugate labelled with fluorescent-isothyocyanate (Sigma F5512) was used as the secondary antibody.

\section{RESULTS}

In 1989, between June and September, 1838 I. ricinus ticks were collected from 20 locations in The Netherlands (Figure 1), and investigated for the presence of $B$. burgdorferi. The number of investigated ticks varied from 300 in Friesland to 50 in Limburg (Table 1). A total of 659 samples were cultured, there being 393 homogenates of groups of four nymphs, and 266 homogenized individual adult ticks; 12 of these 659 cultures $(1.8 \%)$ were contaminated within one week of inoculation.

Mobile spirochetes, morphologically similar to Borrelia were usually first seen after two to three weeks incubation. The extra yield of positive samples after incubation for longer than six weeks was extremely small (1.3\%). There were 75 positive samples, $37(9.4 \%)$ being from nymph homogenates, and $38(14.3 \%)$ from homogenized individual adult ticks. Of the 75 positive samples, 63 were cultured further to achieve serological identification. These 63 isolates gave a positive reaction with the serum of a patient suffering from Lyme borreliosis. Assuming that one of the four nymphs per group was positive, the estimated minimum percentage of infected nymphs was 2.4, whereas for adult ticks, $14.3 \%$ of the total number were infected.

B. burgdorferi were found in I. ricinus nymphs or adults (or both), collected from each of the 20 locations in The Netherlands. In Sittard, Den Burg and Oldeberkoop the minimum percentages of infected nymphs were 8, 9 and 15 respectively. In the remaining 17 locations, the infection percentage varied from zero in Oostvoorne, Warmond and Heerenveen, to four in Sloten. With regard to the adult ticks, only the nine locations where ten or more of them were found, were taken into consideration. Of these nine locations, the ticks from Vrouwenpolder (total 24) and Baarn (total 11) were free from infection, whilst the remaining seven locations had an infection rate of between 1 in 23 (4\%) from Denekamp, and 3 in 10 (30\%) from Texel.

In order to compare the sensitivity of culturing with another method of detection, an indirect IFA (25), 32 samples (22 homogenates of groups of four nymphs, and 10 homogenized individual adult ticks) were investigated using both methods. Culture yielded 11 positive samples, whereas the IFA showed 19 samples to be positive. 


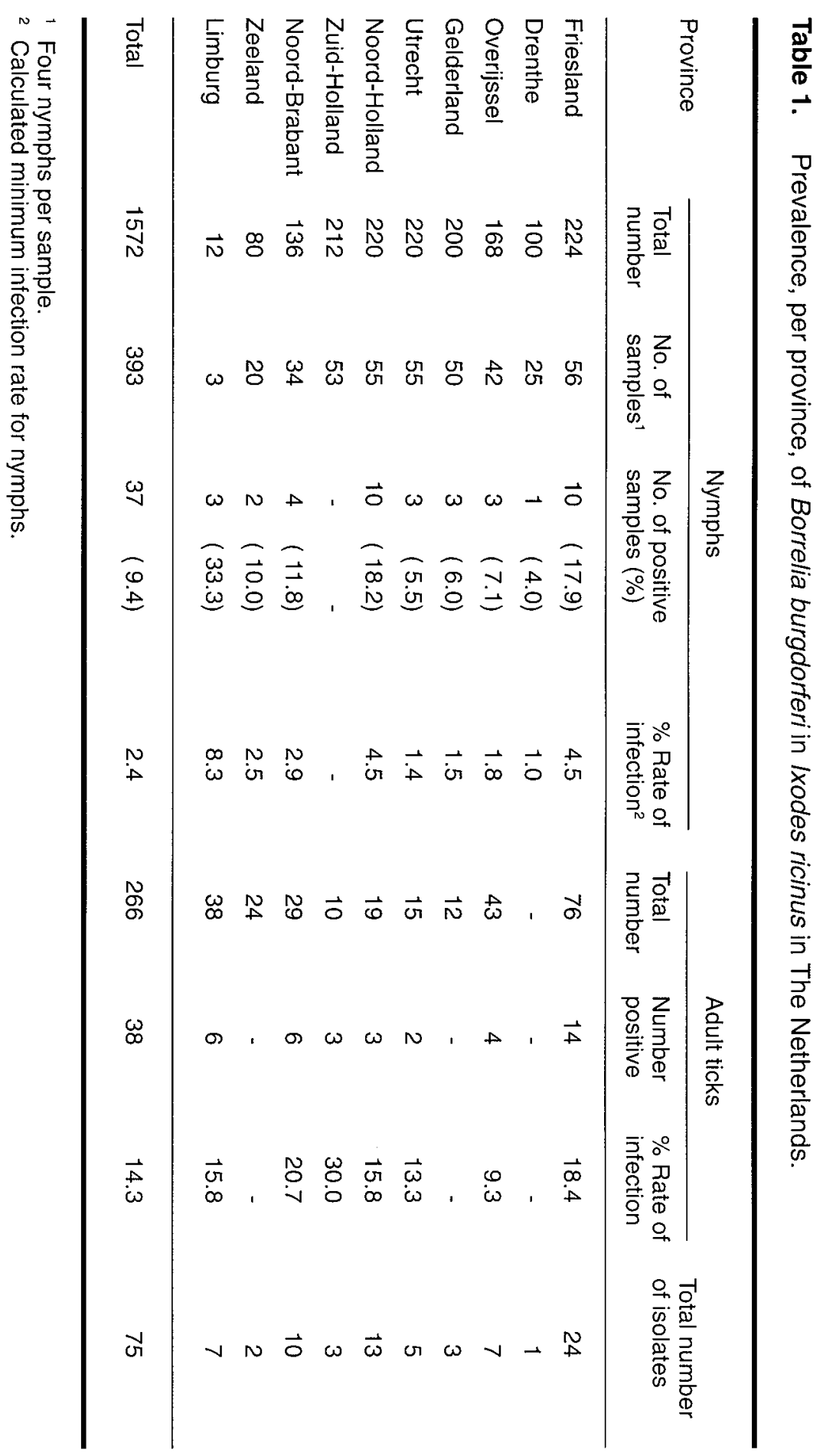




\section{DISCUSSION}

B. burgdorferi infected ticks (I. ricinus) were found in every investigated province. Thus it is clear that there is a widespread risk of contracting Lyme borreliosis in The Netherlands.

In West Berlin the minimum prevalence of infection in 1711 samples was $2.5 \%$ for nymphs and 5 to $10 \%$ for adult ticks (20). In North-Rhine Westphalia, B. burgdorferi was isolated from 19 out of 293 I. ricinus ticks: 7 out of 43 of the adults $(16 \%)$, and 13 out of 250 of the nymphs $(5 \%)$ which were examined in groups of $10(21)$. Swedish workers isolated $B$. burgdorferifrom $17 \%$ of $114 \mathrm{I}$. ricinus ticks collected around Stockholm (22). In Switzerland, positive samples varied from 5 to $34 \%$ in 25 populations of 100 nymphs, examined in a direct IFA (23). Austrian workers found a minimum rate of infection of $2.24 \%$ and a maximum prevalence of $40 \%$, in 1203 I. ricinus ticks investigated in an indirect IFA (24). In southern Germany, a direct IFA on 2403 ticks, detected B. burgdorferi in $20 \%$ of adults, $10 \%$ of nymphs and $1 \%$ of larvae (25).

In this study, infection rates similar to those reported from neighbouring countries were found. In comparison with the USA, where the infection rate of $I$. dammini reaches extreme values of more than $50 \%$ in certain areas, one sees a more uniform picture in Europe (13). The methodology is also important: culture or IFA? Data relating to the sensitivity of IFA or culture, for the detection of $B$. burgdorferi in ticks, are scarce. Investigation of the same tick samples using both methods, gave 29 positive results with IFA, and 19 positive results with culture (28). Similarly, when examining 32 samples with both methods, we found 19 positive samples using indirect IFA, and 11 positive samples using culture. It seems likely, therefore, that the percentage of infected $l$. ricinus in The Netherlands is higher than the one we found using a culture method. The connection between the rate of infection of ticks, and the prevalence of Lyme borreliosis is still unknown. Further research on infection rates of ticks and the prevalence of seropositivity will possibly shed more light on this problem.

Acknowledgements

We would like to thank the personnel of the Veterinary Inspection Service of the Dutch Department of Health and Social Security, for their work in collecting the ticks. 


\section{REFERENCES}

1. Wokke JHJ, Vanneste JAL, Vermeulen M, Op de Coul AAW, Overbeek HC, Janssen RMCM, Brouwer R. Lymfocytaire meningo-radiculitis na insektebeet (syndroom van Bannwarth). Nederlands Tijdschrift voor Geneeskunde 1984; 128: $1796-1799$.

2. van Duin BJ. Erythema chronicum migrans als eerste teken van Lyme-ziekte. Nederlands Tijdschrift voor Geneeskunde 1987; 131: 679-680.

3. van Furth R. Lyme disease: een nieuwe infectieziekte met lokalisatie in verschillende organen. Nederlands Tijdschrift voor Geneeskunde 1987; 131: 657-658.

4. Kuiper $\mathrm{H}$, van Doornum GJJ. Lyme disease: een infectie met lokalisatie in verschillende organen. Nederlands Tijdschrift voor Geneeskunde 1987; 131: 1361.

5. Wokke JHJ. Lyme-ziekte. Nederlands Tijdschrift voor Geneeskunde 1987; 131: 1141.

6. Blaauw AAM, Braat S, van Santen-Hoeufft HM, van der Linden Sj. Cardiologische afwijkingen bij patiënten met Lyme-borreliose. Nederlands Tijdschrift voor Geneeskunde 1988; 132: 2111-2114.

7. Kuiper $\mathrm{H}$, de Jongh BM, Senden PJ. Pacemaker-implantatie wegens totaal atrioventriculair block bij Lyme-borreliose. Nederlands Tijdschrift voor Geneeskunde 1988; 132: 2109-2111.

8. van den Hoogen FHJ, Boerbooms AMTh, Rasker JJ, van de Putte LBA. Gewrichtsklachten na tekebeet; Lyme-arthritis in Nederland. Nederlands Tijdschrift voor Geneeskunde 1988; 132: 1300-1303.

9. de Koning J, Hoogkamp-Korstanje JAA, van der Linde MR, Crijns HJ. Demonstration of spirochetes in cardiac biopsies of patients with Lyme disease. Journal of Infectious Diseases 1989; 160: 150-153.

10. Houwerzyl J, Root JJ, Hoogkamp-Korstanje JAA. A case of Lyme disease with cardiac involvement in the Netherlands. Infection 1984; 12: 358.

11. van der Meer JWM. Lyme-borreliose, de "Hocus Pas" onder de infectieziekten. Nederlands Tijdschrift voor Geneeskunde 1989; 133: 2214-2216.

12. Burgdorfer $W$. Discovery of the Lyme disease spirochete: a historical review. Zentralblatt für Bakteriologie, Mikrobiologie und Hygiene [A] 1986; 263: 7-10.

13. Steere AC. Lyme disease. New England Journal of Medicine 1989; 321: 586596.

14. van Bronswijk JEMH, Rijntjes RH, Garben AFM. De teken (Ixodidae) van de Benelux-landen. Wetenschappelijke mededelingen van de Koninklijke Nederlandse Natuurhistorische Vereniging 1979; 131: 3-35.

15. Piesman J. Transmission of Lyme disease spirochetes (Borrelia burgdorferi). Experimental and Applied Acarology 1989; 7: 1-10.

16. Motuschaka FR, Spielman A. The emergence of Lyme disease in a changing environment in North America and Central Europe. Experimental and Applied Acarology 1986; 2: 337-353.

17. Magnarelli LA, Anderson JF, Fisch D. Transovarial transmission of Borrelia burgdorferi in Ixodes dammini (Acari: Ixodidae). Journal of Infectious Diseases 1987; 156: 234-236. 
18. Ribeiro JM, Mather TN, Piesman J, Spielman A. Dissemination and salivary delivery of Lyme disease spirochetes in vector ticks (Acari: Ixodidae). Journal of Medical Entomology 1987; 24: 201-205.

19. Paul H, Gerth HJ, Ackermann R. Infectiousness for humans of Ixodes ricinus containing Borrelia burgdorferi. Zentralblatt für Bakteriologie, Mikrobiologie und Hygiene [A] 1987; 263: 473-476.

20. Kahl O, Schmidt K, Schönberg A, Laukamm-Josten U, Knulle W, Bienzle U. Prevalence of Borrelia burgdorferi in Ixodes ricinus ticks in Berlin (West). Zentralblatt für Bakteriologie, Mikrobiologie und Hygiene [A] 1989; 270: 434-440.

21. Ackermann R, Kabatzki J, Boisten HP, Steere AC, Grodzicki RL, Hartung S, Runne U. Spirochäten-Ätiologie der Erythema migrans Krankheit. Deutsche Medizinische Wochenschrift 1984; 109: 92-97.

22. Stiernstedt G. Tick-borne Borrelia infection in Sweden. Scandinavian Journal of Infectious Diseases, Supplement 1985; 45: 1-70.

23. Aeschlimann A, Chamot E, Gigon H, Jeanneret JP, Kesseler D, Walther C. Borrelia burgdorferi in Switzerland. Zentralblatt für Bakteriologie, Mikrobiologie und Hygiene [A] 1987; 263: 450-458.

24. Radda A, Burger I, Stanek G, Wewalka G. Austrian hard ticks as vectors of Borrelia burgdorferi, overview. Zentralblatt für Bakteriologie, Mikrobiologie und Hygiene [A] 1986; 263: 79-82.

25. Wilske B, Steinhuber R, Bergmeister H, Fingerle V, Schierz G, Preac-Mursic $V$, Vanek E, Lorbeer B. Lyme-Borreliose in Süddeutschland. Epidemiologische Daten zum Auftreten von Erkrankungsfällen sowie zur Durchseuchung von Zecken (Ixodes ricinus) mit Borrelia burgdorferi. Deutsche Medizinische Wochenschrift 1987; 112: 1730-1736.

26. Barbour AG. Isolation and cultivation of Lyme disease spirochetes. Yale Journal of Biology and Medicine 1984; 57: 521-525.

27. Wilske B, Schierz G, Preac-Mursic V, Weber KK, Pfister HW, Einhäupl K. Serological diagnosis of erythema migrans disease and related disorders. Infection 1984; 12: 331-337.

28. Preac-Mursic V, Wilske B, Schiertz G. European Borrelia burgdorferi isolated from humans and ticks: culture conditions and antibiotic susceptibility. Zentralblatt für Bakteriologie, Mikrobiologie und Hygiene 1986; 263: 112-118. 


\section{4}

\section{GENOTYPIC AND PHENOTYPIC ANALYSIS OF BORRELIA BURGDORFERI ISOLATES FROM THE NETHERLANDS}

MKE Nohlmans ${ }^{1}, \mathrm{R}$ de Boer ${ }^{2}$, AEJM van den Bogaard', CPA van Boven ${ }^{1}$

1 Department of Medical Microbiology, State University of Limburg, Maastricht;

2 Department of Pure and Applied Ecology,

University of Amsterdam, Amsterdam, The Netherlands. 


\section{GENOTYPIC AND PHENOTYPIC ANALYSIS OF BORRELIA BURGDORFERI ISOLATES FROM THE NETHERLANDS}

\section{ABSTRACT}

Sixty-three Borrelia burgdorferi isolates recovered from Ixodes ricinus ticks collected in 17 locations in The Netherlands and three Dutch human skin isolates were characterized by rRNA gene restriction fragment length polymorphism, sodium dodecyl-sulphate polyacrylamide gel electrophoresis, and Western blotting (immunoblotting). All three human isolates belonged to Borrelia burgdorferi group VS461. Of the tick isolates, $29(46 \%)$ were Borrelia burgdorferi sensu stricto, $2(3 \%)$ were group VS461, $19(30 \%)$ were Borrelia garinii, and $13(21 \%)$ were different from any previously described genomic species. On the basis of the criteria described, 12 isolates formed a distinct genomic group, designated M19. rRNA gene restriction patterns of the group M19 isolates resembled but were not identical to the Borrelia garinii patterns. Hybridization of digested DNA with a flagellin probe confirmed the separation of group M19 from the Borrelia garinii isolates. One isolate, M63, was different from all the others. In conclusion, the occurrence of Borrelia burgdorferi sensu stricto, Borrelia garinii, and Borrelia burgdorferigroup VS461 in ticks from The Netherlands, corresponds with the occurrence of these genomic species among tick isolates from other European countries. However, our findings suggest that Borrelia burgdorferi sensu lato probably contains more than three genomic species.

\section{INTRODUCTION}

The spirochete Borrelia burgdorferi is the causative agent of Lyme borreliosis, a multisystemic disease which is considered now to be the most prevalent tick-borne disease in North America, Europe, and other parts of the world with a temperate climate $(1,2)$. Clinical manifestations of Lyme borreliosis depend upon the stage of the infection. Erythema migrans (EM), a localized skin lesion, develops first at the site of the tick bite. Subsequent dissemination of spirochetes from the site of inoculation may result in migratory pain in joints and muscles, headache, neuropathy, and cardiac manifestations. Late infection is characterized by chronic arthritis, progressive encephalomyelitis, or acrodermatitis chronica atrophicans (2). Manifestations and disease severity are highly variable, and asymptomatic infection may occur $(2,3-5)$. The patterns of disease in Europe and in the USA appear to be different. Acrodermatitis chronica atrophicans and neuroborre- 
liosis seem to be more common in Europe, whereas arthritis appears to be more prevalent in the USA $(2,6)$.

B. burgdorferi was first isolated from Ixodes scapularis (formerly known as Ixodes dammini) in 1982 by Burgdorfer et al. $(7,8)$. In 1984 Johnson et al. (9) identified this spirochete as a new species belonging to the genus Borrelia. Thereafter, numerous $B$. burgdorferi isolates have been obtained from ticks and humans, especially in the USA and Europe (10-22). The results of several studies in which workers used protein electrophoresis patterns and reactivity with monoclonal antibodies (MAbs) (23-32), restriction endonuclease analysis (33-35), sequencing of rRNA $(36,37)$, polymerase chain reaction $(P C R)(38,39)$, plasmid profiles $(40,41)$, DNA-DNA re-association $(34,35)$, and ultrastructure analysis (42) have shown that $B$. burgdorferi is quite heterogeneous. Recently, in a study by Baranton et al. (34), in which isolates from Europe, the USA, and Asia were examined, B. burgdorferi sensu lato was split into the genomic species $B$. burgdorferi sensu stricto, Borrelia garinii sp. nov., and B. burgdorferi group VS461 on the basis of DNA relatedness. This classification corresponds to divisions based on other techniques and approaches, as mentioned above. B. burgdorferi sensu stricto was found to be the only genomic species in the USA, whereas among European isolates, all three genomic species occurred. Furthermore, strong evidence that the three genomic species of $B$. burgdorferi exert different organotropic and pathogenic potentials has been found $(20,27)$. In The Netherlands, the predominance of group VS461 and B. garinii in skin and cerebrospinal fluid specimens, respectively, has been demonstrated (20).

In this study we focused on the distribution of the three $B$. burgdorferi species among ticks, collected in broadly distributed locations within The Netherlands. Isolates were characterized by 1 , restriction fragment length polymorphism of two conserved regions of the chromosomal DNA, namely, that encoding for 16S+23S rRNA and for the flagellin protein, and 2. protein electrophoresis followed by Coomassie blue staining, Western blotting and reactivity with MAbs.

\section{MATERIALS AND METHODS}

\section{Borrelia Isolates and Culture Procedures}

In this study, a total of 66 Dutch B. burgdorferi isolates were analysed: 63 I. ricinus isolates (M01 to M63) and three human isolates (MH01, MH02, and MH03) recovered from skin biopsies of three Dutch patients with EM. The tick isolates had been obtained during a 1989 surveillance to study the occurrence $B$. burgdorferi in Ixodes ricinus in The Netherlands (11). In this surveillance, nymphal and adult ticks were collected from several parts of the country between June and September inclusive by means of flagging. Figure 1 presents the 17 geographic locations from which the 63 tick isolates used were recovered. The number of $I$. ricinus isolates per geographic location ranged from 1 to 20 . All 66 isolates used in this study were identified as $B$. burgdorferi with a modified immunofluorescent antibody assay 
using the serum from a patient with Lyme borreliosis as described by Wilske et al. (43). B. burgdorferi was isolated from ticks and human specimens by using BSKII medium (44) with the addition of neomycin, sulphamethoxazole and trimethoprim, as described previously (11) and, after one passage in BSKII medium without antibiotics, was stored at $-76^{\circ} \mathrm{C}$. As references we used the American tick isolate B31 (ATCC 35210) and the German EM isolate PKo (kindly provided by B. Wilske, Max von Pettenkofer Institute, Munich, Germany), which are known to belong to the genomic species $B$. burgdorferi sensu stricto and group VS461, respectively $(20,27,34)$. These two reference isolates were passaged once in BSKII in our laboratory and then stored at $-76^{\circ} \mathrm{C}$. For the purpose of this study all isolates were thawed, passaged once in BSKII medium and then 7- to 10-day-old cultures were used for protein and DNA preparation.

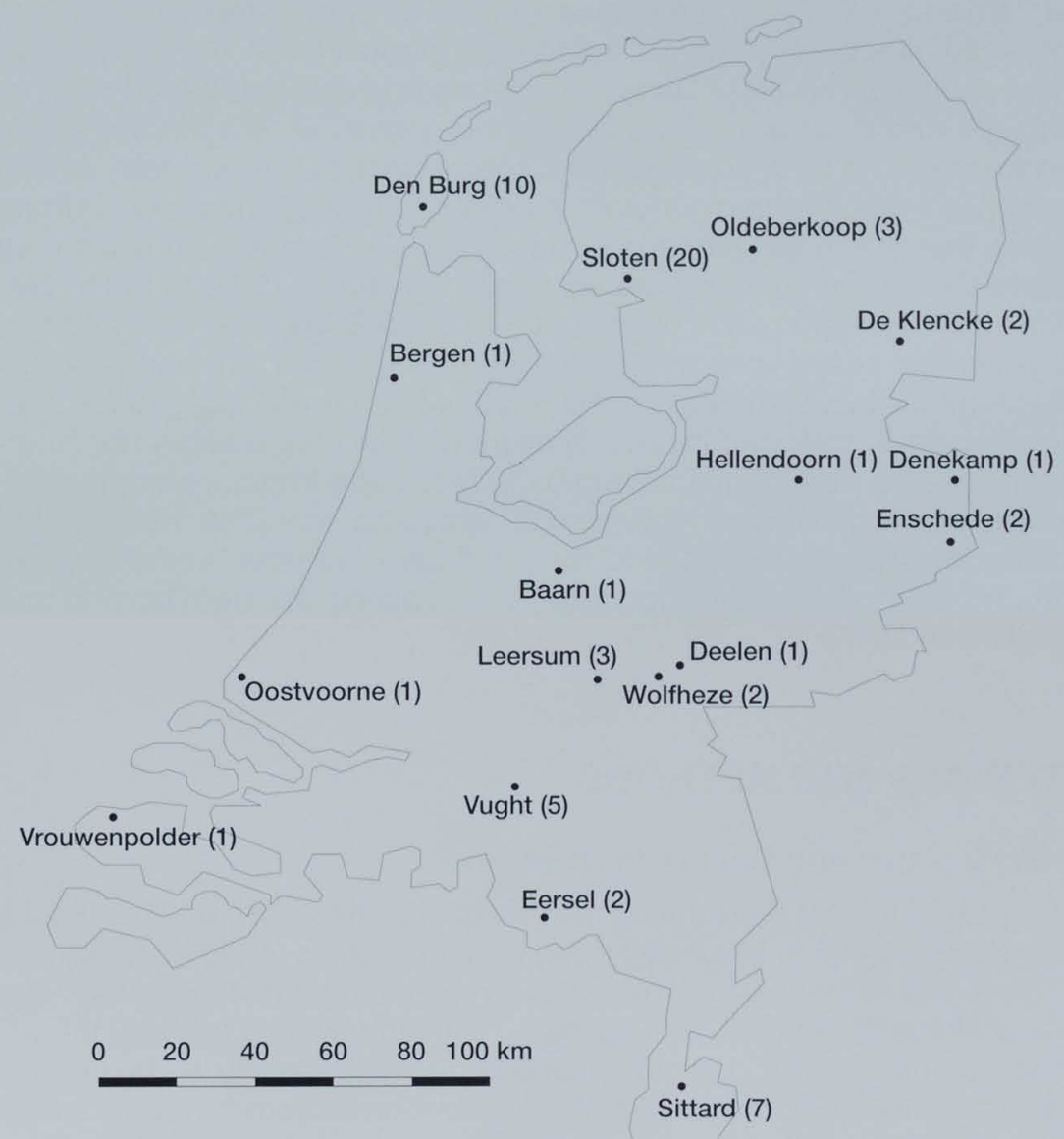

Figure 1. Geographic locations of Ixodes ricinus collection sites in The Netherlands and number of Borrelia burgdorferi isolates (in parentheses) recovered from each site. 


\section{DNA Preparation}

For the preparation of chromosomal DNA, approximately $5 \times 10^{10}$ cells were suspended in TES (25 mM Tris- $\mathrm{HCl}$ [pH 8.0], $10 \mathrm{mM}$ EDTA; $15 \%$ [wt/vol] sucrose), incubated for $15 \mathrm{~min}$. in the presence of lysozyme $(\geq 0.5 \mathrm{mg} / \mathrm{ml}$ on ice) and shaken after the addition of sodium dodecyl-sulphate (SDS; $0.5 \%$ ). Ammonium acetate $(2.2 \mathrm{M})$ was added and the resulting precipitate was separated by centrifugation $(20,000 \times g$ for $10 \mathrm{~min}$.). The pellet was resuspended, treated with RNase $\left(0.1 \mathrm{mg} / \mathrm{ml}, 1 \mathrm{~h}, 37^{\circ} \mathrm{C}\right)$, and subsequently treated, in the presence of SDS $(1 \%)$, with proteinase $\mathrm{K}(0.12 \mathrm{mg} / \mathrm{ml}, 1 \mathrm{~h}$, $37^{\circ} \mathrm{C}$ ). The DNA was extracted with phenol-chloroform (two or three times), precipitated by adding 0.1 volume of $3 \mathrm{M}$ sodium acetate and 2 volumes of $96 \%$ ethanol, and resuspended in water.

\section{Restriction Enzyme Digests, Agarose Gel Electrophoresis and Southern Blot}

DNA was digested with HindIII or EcoRV endonuclease (Pharmacia) as described in the instructions of the manufacturer. Electrophoresis was performed using $0.8 \%$ agarose in TBE $(89 \mathrm{mM}$ Tris, $89 \mathrm{mM}$ boric acid, $2 \mathrm{mM}$ EDTA [pH 8.0]) at $90 \mathrm{~V}$ for 3 hours. As a molecular mass standard, HindIIIdigested $\lambda$ DNA was included in each gel, showing six clearly visible fragments (23.13 to $2.02 \mathrm{kbp}$ ). DNA samples of the two reference isolates (B31 and $\mathrm{PKO}$ ) were also included in each gel. DNA fragments were transferred to Hybond membranes (Amersham, International, Berks, England) by means of a horizontal capillary system as described in the instructions of the manufacturer.

\section{Hybridization of DNA Fragments}

Hybridization of transferred fragments was performed essentially as described by Grimont et al. (45). 16S+23S rRNA from Escherichia coli (Boehringer, Mannheim, Germany) and a 730-bp fragment of the flagellin gene of $B$. burgdorferi B31, which had been prepared as described by Gassmann (46) (kindly provided by S. Rijpkema, National Institute of Public Health and Environmental Protection, Bilthoven, The Netherlands), end-labelled with $\left[\gamma-{ }^{32} P\right]$ ATP (Amersham) by using T4 polynucleotide kinase (Pharmacia) as described in the manufacturer's instructions, were used as probes. DNA fragments were hybridized at $60^{\circ} \mathrm{C}$, and membranes were washed five times with $2 \times$ SSC, containing $0.1 \%$ SDS, at $55^{\circ} \mathrm{C}(1 \times$ SSC is $0.15 \mathrm{M} \mathrm{NaCl}$ plus $0.015 \mathrm{M}$ sodium citrate $[\mathrm{pH} 7.0])$. Membranes were autoradiographed with Kodak X-Omat S film and an intensifying screen at $-70^{\circ} \mathrm{C}$. The gene restriction patterns were classified by visual inspection on the basis of similarity.

\section{Protein Electrophoresis}

Whole-cell sonicates of the $68 \mathrm{~B}$. burgdorferi isolates were prepared essentially as described by Craft et al. (47). The protein concentrations were determined by the Bio-Rad protein assay (Bio-Rad Laboratories, Munich, Germa- 
ny). SDS-polyacrylamide gel electrophoresis (SDS-PAGE) was performed essentially as described by Laemmli (48). In preparing the sample buffer, 2 mercaptoethanol ( $5 \%$ final concentration) was used as the reducing agent. The separation gel $(\mathrm{pH} 8.8)$ contained $11 \%$ acrylamide. The concentration of acrylamide in the stacking gel $(\mathrm{pH} 6.8)$ was $4 \%$. Electrophoresis was performed in a Protean II Slab Cell (Bio-Rad Laboratories) on $0.5 \mathrm{~mm}$ gels, using $5 \mu \mathrm{g}$ of protein per lane. B. burgdorferi B31 and low molecular mass standards (LMW Calibration Kit; Pharmacia) were run with each gel. Gels were either stained with Coomassie brilliant blue (R-250; Merck AG, Darmstadt, Germany) or immediately used for blotting. The relative molecular mass $\left(M_{\mathrm{r}}\right)$ of major proteins in the ranges of $30 \mathrm{kDa}$ to $36 \mathrm{kDa}$ and $22 \mathrm{kDa}$ were determined by comparing their electrophoretic mobility with that of the standard proteins.

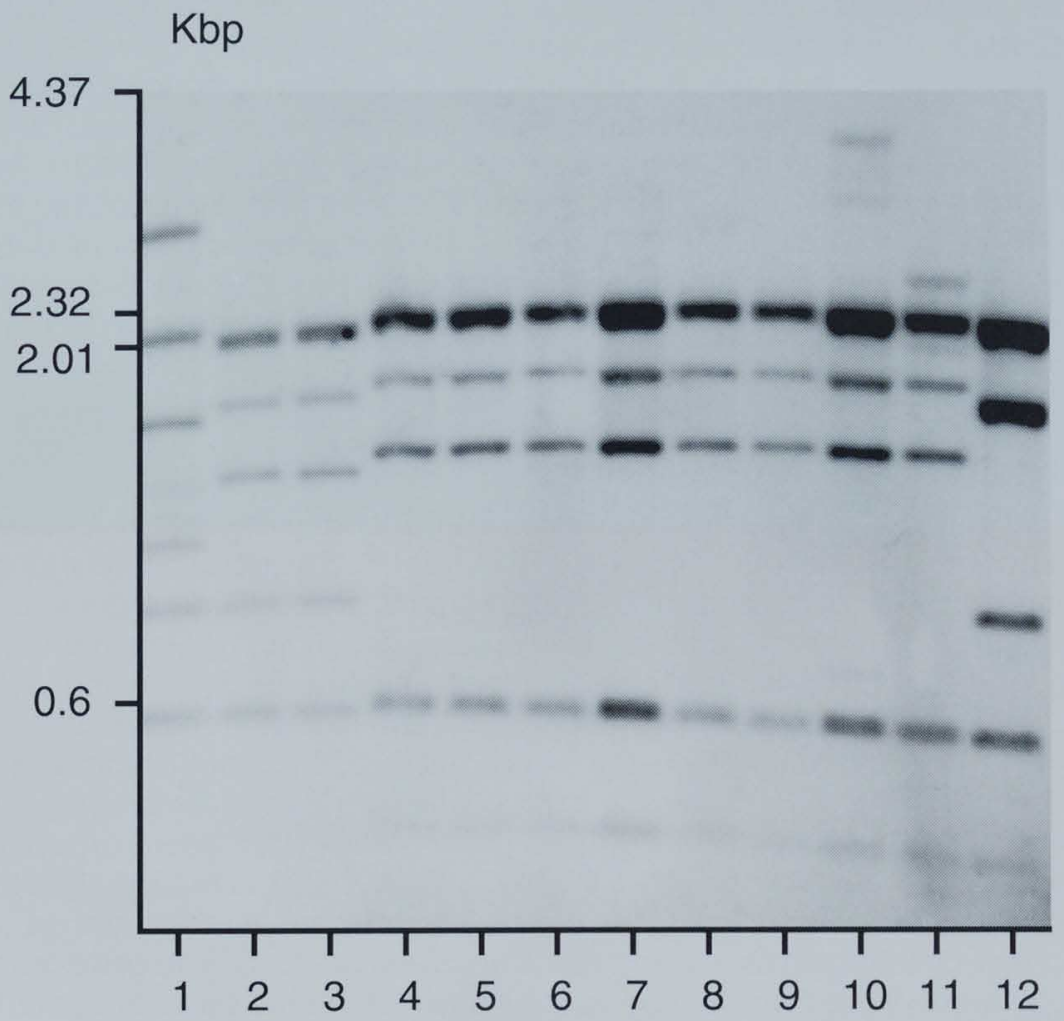

Figure 2. Gene restriction patterns of Borrelia burgdorferi isolates recovered from ticks collected in The Netherlands after cleavage with HindlII. DNA digests were hybridized with 16S+23S rRNA of Escherichia coli. Lanes: 1 and 12, controls PKo and B31, respectively; 2 and 3 , isolates typed as group M19; 4 to 11 , isolates typed as Borrelia garinii. 


\section{Western blot (immunoblot)}

Proteins were transferred from the gels to nitrocellulose paper in a Multiphor II Novablot (Pharmacia) by use of a transfer buffer prepared by the method of Towbin et al. (49). Electrophoresis was carried out at $0.8 \mathrm{~mA} / \mathrm{cm}^{2}$ of the trans-unit for $1 \mathrm{~h}$. After transfer, the blots were blocked overnight with $1 \%$ bovine serum albumin in phosphate-buffered saline (PBS), subsequently immersed in PBS with the addition of $0.5 \%$ Tween 20 (PBS-T), and incubated at room temperature for $30 \mathrm{~min}$. The blots were then incubated with MAb at room temperature for $60 \mathrm{~min}$. MAb was diluted 1:50 (anti-OspA and anti-flagellum) or 1:10 (anti-OspB) in PBS-T. After washing three times with PBS-T, the blots were transferred to a 1:600 dilution of alkaline phosphatase-labelled anti-mouse immunoglobulin G (A1902; Sigma Chemical Co., St. Louis, Mo.) and incubated at room temperature for $60 \mathrm{~min}$. The blots were washed twice with PBS-T, incubated with Tris $-\mathrm{MgCl}_{2}(\mathrm{pH}$ 9.5), and transferred to a dimethylformamide buffer solution containing $165 \mu \mathrm{g}$ of bromo-chloro-indolyl-phosphate (B8503; Sigma) per $\mathrm{ml}$ and $330 \mu \mathrm{g}$ of nitro blue tetrazolium (N6876; Sigma) per ml. After 5 min. of incubation, the enzymatic reaction was stopped by rinsing the blots in Tris-EDTA ( $\mathrm{pH} 7.5)$.

\section{MAbs}

The following MAbs (Symbicom, Umeå, Sweden) directed against B. burgdorferi B31 were used: H9724 (50) against periplasmic Borrelia flagella, H5332 (51) and H3TS (23) against different epitopes of the OspA protein, and $H 6831$ (52) against the OspB protein.

\section{Statistics}

$\chi^{2}$-test and Fisher's exact test were used to test the significance of differences between proportions.

\section{RESULTS}

\section{rRNA Gene Restriction Patterns}

Our isolates could be subdivided into five groups. The first group was represented by a single isolate, $M 63$, a tick isolate that was different from all the others. Cleavage of its DNA with Hindlll resulted in four fragments hybridizing with the $16+23 \mathrm{~S}$ rRNA probe. Two of these fragments $(2.1$ and $0.6 \mathrm{kbp}$ ) were common to all other isolates. The sizes of the two unique fragments were in the region of 1 to $1.5 \mathrm{kbp}$ and, roughly, $3 \mathrm{kbp}$, respectively. Digestion of M63 DNA with EcoRV resulted in three fragments, one of which (3.2 $\mathrm{kbp}$ ) was common to all other isolates. The other two were in the region of 6 to $7 \mathrm{kbp}$ and, roughly, $3 \mathrm{kbp}$, respectively. The second group contained $B$. burgdorferi $\mathrm{B} 31$ and 29 of our tick isolates. These isolates revealed a HindIII and $E c o R V$ restriction pattern identical to that of genomic species $B$. burgdor- 
feri sensu stricto as described by Baranton et al. (34). Two of these isolates, M11 and M13, both collected near Sloten, The Netherlands, had an additional Hindlll fragment of approximately $2.4 \mathrm{kbp}$, just like some of the isolates described by Baranton et al. (34). The third group comprised two tick isolates, M10 and M55, and all three of our skin isolates. The HindIII and EcoRV restriction patterns of these isolates were identical to that of the PKo reference isolate and thus belong to group VS461 $(27,31,34)$. The HindIII restriction patterns showed six fragments (Figure 2, lane 1), i.e. one fragment in addition to those described by Baranton et al. (34). This additional fragment was in the range of $0.9-1.5 \mathrm{kbp}$. The fourth group, comprising 19 tick isolates, had the characteristics of B. garinii, i.e. a 5.3-kbp EcoRV fragment and a 1.3-kbp Hindlll fragment. Again, we consistently found an additional Hindlll fragment which was not described by Baranton et al. (34), this time in the region of 1.6 to $1.7 \mathrm{kbp}$. The fifth group, comprising $12 \mathrm{I}$. ricinus isolates, produced restriction patterns which were different from those observed in the B. garinii group in that all isolates showed an additional weak band of approximately $0.8 \mathrm{kbp}$ and slightly lower molecular masses of the other four fragments obtained after cleavage with HindlII (Figure 2, lanes 2 and 3). Furthermore, the largest fragment observed after digestion with EcoRV had a higher molecular mass than the corresponding band observed in the $B$. garinii group (Figure $3 \mathrm{~A}$, lanes 4 to 6 and 7 to 9 , respectively). This fifth group was designated the M19 group.

\section{Flagellin Gene Restriction Patterns}

EcoRV digests were also hybridized with the flagellin probe (Figure 3B). The restriction patterns of the group M19 isolates were quite uniform (one band in the region 3 to $7 \mathrm{kbp}$ ) and different from the $B$. garinii isolates, which were uniform among themselves (one band in the region of 10 to $20 \mathrm{kbp}$ ). The distinction between $B$. garinii and the group M19 isolates was thereby confirmed.

\section{Protein Patterns and Reactivity with MAbs}

Although Coomassie-blue stained SDS-PAGE protein patterns showed extensive heterogeneity, a limited number of constant patterns concerning several major proteins in the range of 30 to $36 \mathrm{kDa}$ were distinguished (Figure 4). The distribution of these four protein patterns as well as the corresponding reactivities with MAbs among the five genomic groups is presented in Table 1. The 29 isolates showing the genotypic characteristics of $B$. burgdorferi sensu stricto were quite uniform concerning major protein patterns and reactivity with MAbs $\mathrm{H} 5332$ and H3TS directed against OspA and with MAb H6831 directed against OspB. The major protein patterns of the five group VS461 isolates were also uniform and different from the $B$. burgdorferi sensu stricto isolates. These isolates produced major bands at 33 and $35 \mathrm{kDa}$. None of these isolates were reactive with the MAb H5332, H3TS, or H6831. The B. garinii isolates and the group M19 isolates could not be distinguished unambiguously on the basis of protein patterns. A com- 

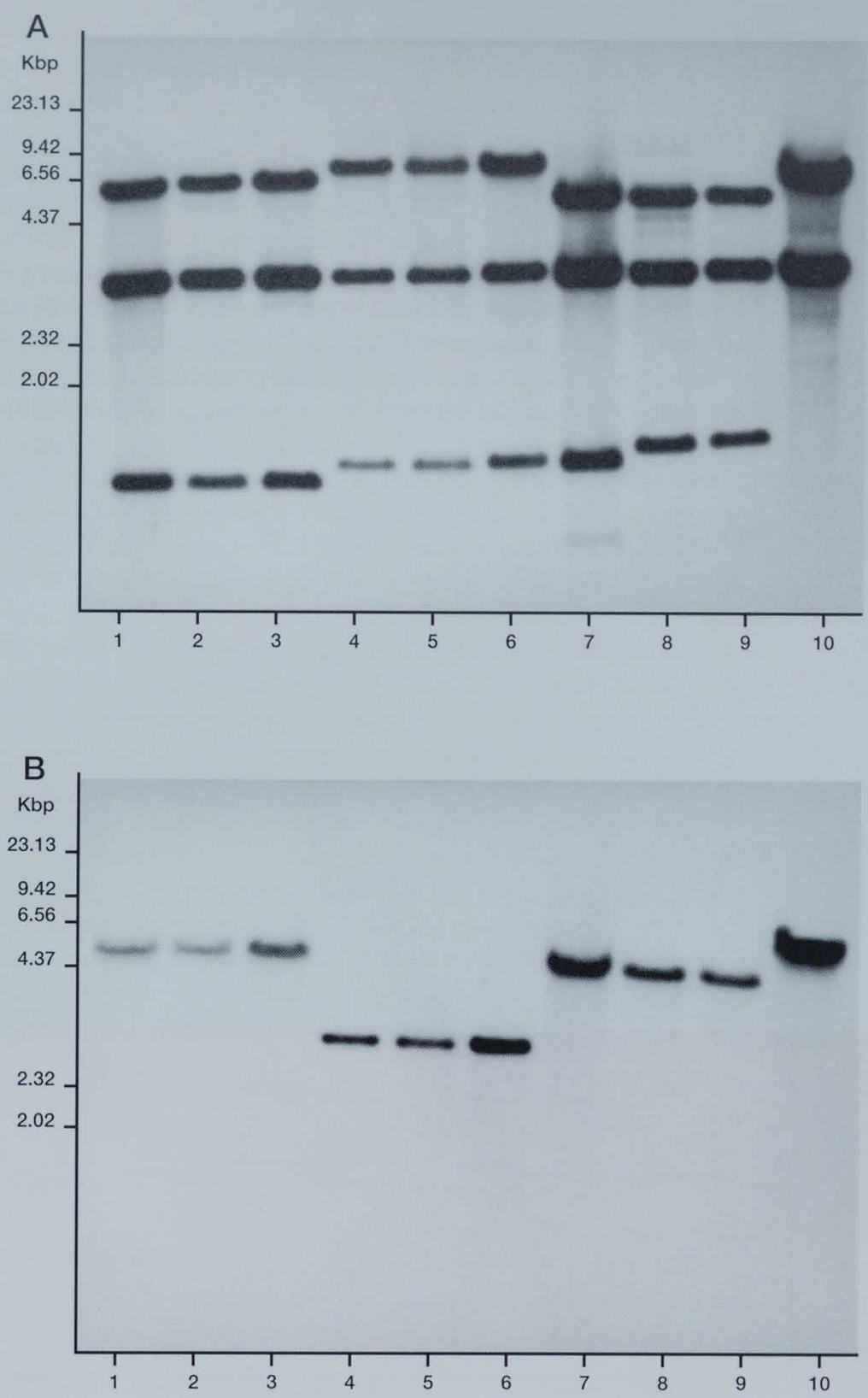

Figure 3. Gene restriction patterns of Borrelia burgdorferi isolates recovered from ticks collected in The Netherlands after cleavage with EcoRV. A. Hybridization of DNA digests with 16S+23S rRNA of Escherichia coli; B. Hybridization of the same digests as those of panel $\mathrm{A}$ with the flagellum probe. Lanes: 1 and 10, controls PKo and B31, respectively; 2 and 3, isolates typed as Borrelia burgdorferi group VS461; 4 to 6 , isolates typed as group M19; 7 to 9 , isolates typed as Borrelia garinii. 
mon feature of all these isolates was the absence of reactivity with MAb $\mathrm{H} 6831$, directed against OspB, and the absence of a protein band in the 34$\mathrm{kDa}$ range, which separated them from all the others. The isolates were variable concerning the molecular mass of OspA (either 33 or $34 \mathrm{kDa}$ ) and their reactivity with MAb $\mathrm{H} 5332$, but all four conceivable combinations of these characters (33-kDA protein-H5332+, 33-kDa protein-H5332-, 34-kDa protein-H5332+, and 34-kDa protein-H5332-) were found. Different combinations were found quite often at the same geographic location. A 33$\mathrm{kDa}$ OspA was in 12 cases combined with negative $\mathrm{H} 5332$ reactivity and in 9 cases with positive $\mathrm{H} 5332$ reactivity. Only 1 of the 10 isolates with a 34$\mathrm{kDa}$ OspA had positive $\mathrm{H} 5332$ reactivity (Fisher's exact test, $\mathrm{p}>0.10$, two sided). B. garinii had the 33-kDa variant of OspA much more frequently than the group M19 isolates (Fisher's exact test, $p<0.001$, two sided). Also, reactivity with MAb $\mathrm{H} 5332$ was seen relatively more often in the $B$. garinii isolates (Fisher's exact test, $p=0.05$, two sided). Thirty-seven of the 66 isolates had a prominent protein band at about $22 \mathrm{kDa}$, corresponding with the OspC region (20 to $25 \mathrm{kDa}$ ) (53). The intensity of this band was scored (-, + or ++ ) without awareness of the genetic characters of the isolates. The proportions of 22-kDa negative isolates were significantly different among $B$. burgdorferi sensu stricto ( 6 of 29 isolates), B. garinii (9 of 19 isolates), and

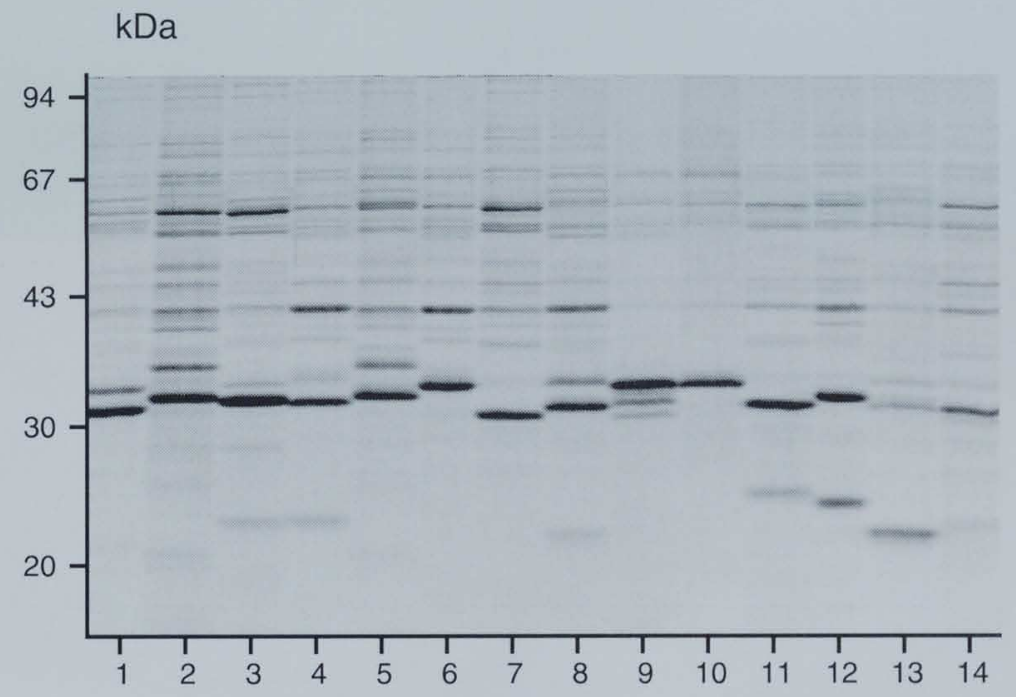

Figure 4. Coomassie blue-stained SDS-PAGE of whole-cell lysates of Borrelia burgdorferi isolated from ticks in The Netherlands. Lanes: 1 , control B31; 2, control PKo; 3 , 4 , and 12 , isolates genotyped as Borrelia garinii; 5 , isolate genotyped as Borrelia burgdorferi group VS461; 6,9 , and 10 , isolates genotyped as group $\mathrm{M} 19 ; 7$, isolate not genotyped and therefore not included in this study; 8,13 and 14, isolates genotyped as Borrelia burgdorferi sensu stricto; 11, isolate genotyped as group M63. 
the group M19 isolates ( 11 of 12 isolates) ( $\chi^{2}$-test, degrees of freedom $=2$, $p<0.001)$. It is also remarkable that the three group VS461 isolates of human origin were $22 \mathrm{kDa}$ positive (++), whereas the two group VS461 tick isolates were $22 \mathrm{kDa}$ negative.

\section{Geographic Distribution of Genomic Groups}

Ticks collected from one location, Sloten, located in the northern part of The Netherlands, yielded 20 isolates. Sixteen of these were B. burgdorferisensu stricto isolates, three were $B$. garinii isolates, and one was a group M19 isolate. The high percentage of $B$. burgdorferi sensu stricto isolates in this sample departs significantly from its representation among the rest of our isolates $\left(\chi^{2}\right.$-test, degree of freedom $\left.=1, p=<0.001\right)$. The numbers of isolates from the other locations were much smaller and therefore constitute a more balanced sample of tick isolates. A location on the island of Texel, Den Burg, The Netherlands, yielded 10 isolates: 4 were B. garinii and 6 were group M19. All seven isolates from Sittard, located in the southern part of The Netherlands, were $B$. garinii. From the remaining locations, we never obtained more than five isolates, and more often than not, the isolates from one location represented two or even three different types.

\section{DISCUSSION}

For comparison of our findings with the available information on I. ricinus isolates from European countries, the studies of Baranton et al. (34), Wallich et al. (54) and Wilske et al. (27) were consulted. On the basis of DNA-DNA reassociation studies and other genetic characters, Baranton et al. (34) distinguished three genomic species, i.e., B. burgdorferi sensu stricto, B. garinii, and $B$. burgdorferi group VS461, among $16 I$. ricinus isolates. Wallich et al. (54) characterized 19 tick isolates which were not included in the Baranton study, and another $17 \mathrm{I}$. ricinus isolates were characterized by Wilske et al. (27), bringing the total to 52 . Of these 52 isolates from widely dispersed locations in Europe, 17 (33\%) were in the same division as B. burgdorferi B31 and thus corresponded to the genomic species $B$. burgdorferi sensu stricto. Of our 63 tick isolates, $29(46 \%)$ were $B$. burgdorferi sensu stricto $\left(\chi^{2}\right.$-test, degree of freedom $\left.=1, p=0.15\right)$. However, as argued above, a better representation of tick isolates is obtained when the 20 isolates from Sloten are disregarded. Then, $13(30 \%)$ of 43 isolates are B. burgdorferi sensu stricto. This percentage also agrees reasonably well with the proportion generally found among European tick isolates $\left(\chi^{2}\right.$-test, degree of freedom $=1, p=0.10$ ). Thus, the genomic species $B$. burgdorferi sensu stricto is commonly found in European I. ricinus ticks. Of the three recognized genomic species, this is the only one found to date in North America, where it is associated with rheumatic manifestations that may be relatively rare in European patients with Lyme borreliosis $(2,6)$. Variability of pathogenic properties apparently also exists within genomic species. 


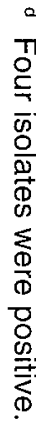

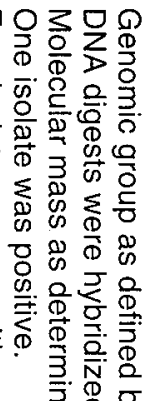

可

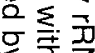

们可

识음

七刀

唡

而高

के

$+$

记

可

$\sum_{\supset}$

오옥

근.

क

ऽ。

ํ. 음

옹

8

?

五 


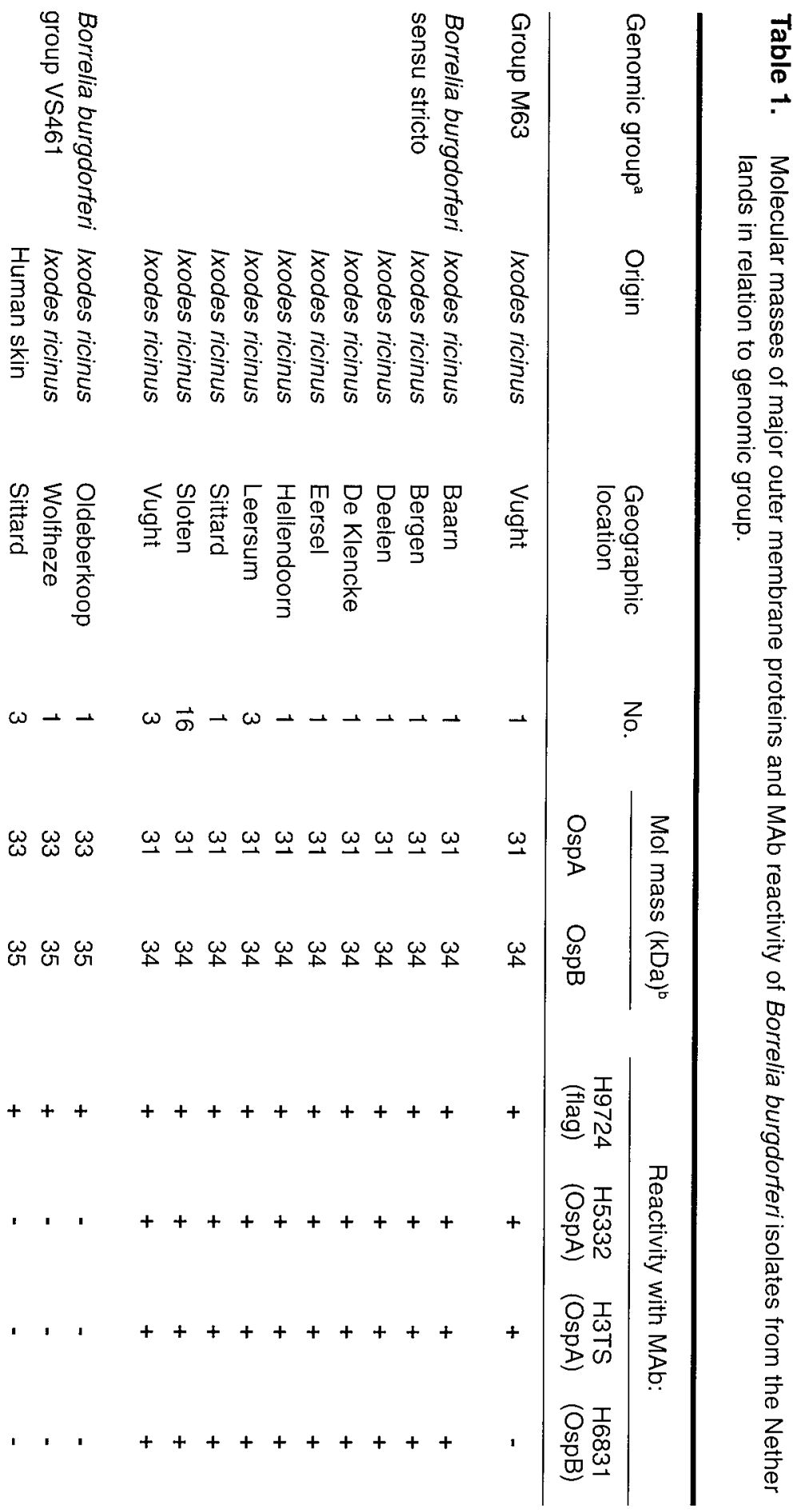


B. burgdorferi group VS461 appears to be less common. Only $4(8 \%)$ of the 52 tick isolates of the combined studies of Baranton et al. (34), Wallich et al. (54), and Wilske et al. (27) belong to this group. This agrees well with our findings. Only two (3\%) of our tick isolates were group VS461. It is, however, in striking contrast with the results of van Dam et al. (20). These authors also isolated $B$. burgdorferi from ticks collected in The Netherlands. All of the 26 tick isolates that were obtained from only two collection sites were group VS461 (Fisher's exact test, $p<0.0001$, two sided). Van Dam et al. (20) did not specify the two geographic locations where they had collected the ticks. Of the 17 locations where our isolates were collected, only two yielded group VS461. A discrepancy like this would be found purely by chance only once in 25 trials (Fisher's exact test, $p=0.039$, two sided), not considering the fact that the locations where our isolates were found also yielded other genomic species. In their report, van Dam et al. (20) suggest that different growth and survival rates for the various genomic species in their culture medium may have resulted in an overrepresentation of certain isolates. Even if that explanation is correct, it is still notable that so many group VS461 isolates were obtained. A survey of $B$. burgdorferi in ticks using PCR technology may be less vulnerable to sampling biases than our method, which depends on successful culturing. The scarcity of group VS461 isolates among the tick isolates also contrasts with the preponderance of this type generally found among EM isolates $(20,27)$. Our data are in good agreement with this general finding. All three of our skin isolates were $B$. burgdorferi group VS461. Apparently, this genomic species is more prone to cause EM and acrodermatitis chronica atrophicans than any of the others $(20,27,31)$.

Among the 31 remaining isolates, two types, represented by 19 and 12 isolates, respectively, were distinguished. The distinction was originally based on the restriction fragment length polymorphism patterns produced by the $16 S+23 S$ rRNA sequences. Later, it was fully confirmed by the unrelated, conserved region of the genomic DNA, encoding for the flagellin protein, positioned more than $250 \mathrm{kbp}$ away from the rRNA gene cluster (55). One group of isolates is probably conspecific with $B$. garinii. The other one, designated group $\mathrm{M} 19$, needs further analysis to determine whether this group constitutes a new genomic species.

Several studies have demonstrated that classification of $B$. burgdorferi isolates using the electrophoretic mobility and MAb reactivity of OspA and OspB correlates well with genetic analysis such as restriction pattern of chromosomal DNA, rRNA restriction pattern, and DNA-DNA hybridization $(27,34,36,56)$. This indicates that the plasmids encoding for OspA and OspB are not commonly exchanged between borreliae that belong to different genomic species. In the present study, only three of the five groups distinguished by restriction fragment length polymorphism could also be distinguished on the basis of electrophoretic mobility and MAb reactivity of OspA and OspB. However, the number of MAbs used in this study was small. Peter et al. (56) who classified 20 Swiss $I$. ricinus isolates on the basis of polymorphism of OspA and OspB, identified four groups which corresponded to divisions based on genetic analysis. Two of these groups produced a 
single OspA protein either at 33 or $33.5 \mathrm{kDa}$. Separation of these two groups was possible on the basis of reactivity with MAb D6, directed against a 12kDa protein of $B$. burgdorferi. Concerning our $B$. garinii and group M19 isolates, which produced a single OspA at 33 or $34 \mathrm{kDa}$, further analysis using a broader set of MAbs is needed to determine whether these groups can also be identified on the basis of phenotypic characteristics.

There are indications that protein profiles and antigenic characterization of surface proteins may be less reliable for the classification of $B$. burgdorferi $(57,58)$ since antigenic changes may occur during in-vitro cultivation. These changes may be due to loss of plasmids, gene rearrangements, or gene expression and regulatory processes (59-61). This was the main reason why we used only low-passaged isolates. Wilske et al. (58) noticed that some isolates of $B$. burgdorferi expressed the OspC at the expense of OspA. Twenty-two of our 66 isolates clearly produced a protein band in the OspC region ( 20 to $25 \mathrm{kDa}$ ), but there were always sufficient amounts of OspA detectable to allow its determination. Furthermore, comparison of 2- and 40-passage isolates (data not shown) revealed no differences in electrophoretic mobilities and MAb reactivities of OspA and OspB, which convinced us that the phenotypic expression of these proteins is maintained during cultivation.

The proportion of isolates producing a $22-\mathrm{kDa}$ band differed significantly among $B$. burgdorferi sensu stricto $(79 \%), B$. garinii $(58 \%)$, and the group $\mathrm{M} 19$ isolates $(5 \%)$. This finding may suggest that OspC, in addition to OspA and $\mathrm{OspB}$, may be useful in the classification of $B$. burgdorferi isolates on the basis of Osp profiles. However, the expression of OspC has been shown to be an unstable feature (53). Concerning the percentages described above, it also should be mentioned that we did not verify the identity of the 22-kDa band as OspC by antibody recognition. This is particularly important in light of the findings that in the 20 - to $25-\mathrm{kDa}$ range, proteins that are not surface associated may be seen and mistaken for OspC (53). OspC is, besides the flagellin protein, a major target of the early immune response in patients with Lyme borreliosis. Verification of OspC by means of an MAb is important when serodiagnostic antigens should be prepared.

The findings in the present study that $B$. burgdorferi may contain more than three genomic species is important in light of the recent findings that different subspecies are associated with distinct clinical pictures of Lyme borreliosis and that, in particular, B. garinii is associated with extracutaneous manifestations $(20,27)$. Further analysis to more clearly define the status of the M19 group is needed.

\section{Acknowledgement}

The investigations were supported financially by the national "Praeventiefonds". 


\section{REFERENCES}

1. Schmid GP. The global distribution of Lyme disease. Reviews of Infectious Diseases 1985; 7: 41-50.

2. Steere AC. Lyme disease. New England Journal of Medicine 1989; 321: 586596.

3. Gustafson R, Svenungsson B, Gardulf A, Stiernstedt G, Forsgren M. Prevalence of tick-borne encephalitis and Lyme borreliosis in a defined Swedish population. Scandinavian Journal of Infectious Diseases 1990; 22: 297-306.

4. Fahrer $H$, van der Linden SM, Sauvain MJ, Gern L, Zhioua E, Aeschlimann A. The prevalence and incidence of clinical and asymptomatic Lyme borreliosis in a population at risk. Journal of Infectious Diseases 1991; 163: 305-310.

5. Nohlmans MKE, van den BogaardAEJM, Blaauw AAM, van Boven CPA. Prevalentie van Lyme-borreliose in Nederland. Nederlands Tijdschrift voor Geneeskunde 1991; 135: 2288-2292.

6. Weber K, Schierz G, Wilske B, Preac-Mursic V. European erythema migrans disease and related disorders. Yale Journal of Biology and Medicine 1984; 57 : 463-471.

7. Burgdorfer W, Barbour AG, Hayes SF, Benach JL, Grunwaldt E, Davis JP. Lyme disease - a tick-borne spirochetosis ? Science 1982; 216: 1317-1319.

8. Wesson DM, McLain DK, Oliver JH, Piesman J, Collins FH. Investigation of the validity of species status of Ixodes dammini (Acari: Ixodidae) using rDNA. Proceedings of the National Academy of Science 1993; 90: 10221-10225.

9. Johnson RC, Schmid GP, Hyde FW, Steigerwald AG, Brenner DJ. Borrelia burgdorferi sp. nv.: etiologic agent of Lyme disease. International Journal of Systematic Bacteriology 1984; 34: 436-497.

10. Kahl O, Schmidt K, Schönberg A, Laukamm-Josten U, Knülle W, Bienzle U. Prevalence of Borrelia burgdorferi in Ixodes ricinus ticks in Berlin (West). Zentralblatt für Bakteriologie, Mikrobiologie und Hygiene [A] 1989; 270: 434440.

11. Nohlmans MKE, de Boer R, van den Bogaard AEJM, BlaauwAAM, van Boven CPA. Voorkomen van Borrelia burgdorferi in Ixodes ricinus in Nederland. Nederlands Tijdschrift voor Geneeskunde 1990; 134: 1300-1303.

12. Aeschlimann A, Chamot E, Gigon H, Jeanneref JP, Kesseler D, Walther C. $B$. burgdorferi in Switzerland. Zentralblatt für Bakteriologie, Mikrobiologie und Hygiene [A] 1987; 263: 450-458.

13. Stiernstedt G. Tick-borne Borrelia infection in Sweden. Scandinavian Journal of Infectious Diseases, Supplement 1985; $45: 1-70$.

14. Karlsson M, Hovind-Hougen K, Svenungsson B, Stiernstedt G. Cultivation and characterization of spirochetes from cerebrospinal fluid of patients with Lyme borreliosis. Journal of Clinical Microbiology 1990; 28: 473-479.

15. Nadelman RB, Pavia CS, Magnarelli LA, Wormser GP. Isolation of Borrelia burgdorferi from the blood of seven patients with Lyme disease. American Journal of Medicine 1990; 88: 21-26.

16. Preac-Mursic V, Wilske B, Schierz G, Pfister HW, Einhäupl K. Repeated isolation of spirochetes from the cerebrospinal fluid of a patient with meningoradiculitis Bannwarth. European Journal of Clinical Microbiology 1984; 3: 564-565. 
17. Steere AC, Grodzicki RL, Kornblatt AN, Craft JE, Barbour AG, Burgdorfer W, Schmid GP, Johnson E, Malawista SE. The spirochetal etiology of Lyme disease. New England Journal of Medicine 1983; 308: 733-740.

18. Miyamoto K, Nakao M, Uchikawa K, Fujita H. Prevalence of Lyme borreliosis spirochetes in ixodid ticks of Japan, with special reference to a new potential vector, Ixodes ovatus (Acari: Ixodidae). Journal of Medical Entomology 1992; 29: 216-220.

19. Rawlings JA, Fournier PV, Teltow GJ. Isolation of Borrelia spirochetes from patients in Texas. Journal of Clinical Microbiology 1987; 25: 1148-1150.

20. van Dam AP, Kuiper H, Vos K, Widjojokusumo A, de Jongh BM, Spanjaard L, Ramselaar ACP, Kramer MD, Dankert J. Different genospecies of Borrelia burgdorferiare associated with distinct clinical manifestations of Lyme borreliosis. Clinical Infectious Diseases 1993; 17: 708-717.

21. Stanek G, Klein J, Bittner R, Glogar D. Isolation of Borrelia burgdorferi from the myocardium of a patient with longstanding cardiomyopathy. New England Journal of Medicine 1990; 332: 249-252.

22. Schmidli J, Hunziger T, Moesli P, Scaad UB. Cultivation of Borrelia burgdorferi from joint fluid three months after treatment of facial palsy due to Lyme borreliosis. Journal of Infectious Diseases 1988; 158: 905-906.

23. Barbour AG, Heiland RA, Howe TR. Heterogeneity of major proteins in Lyme disease borreliae: a molecular analysis of North American and European isolates. Journal of Infectious Diseases 1985; 152: 478-484.

24. Bissett ML, Hill W. Characterization of Borrelia burgdorferi strains isolated from Ixodes pacificus ticks in California. Journal of Clinical Microbiology 1987; 25: 2296-2301.

25. Anderson JF, Barthold SW, Magnarelli LA. Infectious but non-pathogenic isolate of Borrelia burgdorferi. Journal of Clinical Microbiology 1990; 28: 26932699.

26. Bergström S, Olsen B, Burman N, Gothefors L, Jaenson TG, Jonsson M, Mejlon HA. Molecular characterization of Borrelia burgdorferi isolated from Ixodes ricinus in northern Sweden. Scandinavian Journal of Infectious Diseases 1992; 24: 181-188.

27. Wilske B, Preac-Mursic V, Göbel UB, Graf B, Jauris S, Soutschek E, Schwab E, Zumstein G. An OspA serotyping system for Borrelia burgdorferi based on reactivity with monoclonal antibodies and OspA sequence analysis. Journal of Clinical Microbiology 1993; 31: 340-350.

28. Khanakha G, Millner MM, Müllegger RR, Stanek G. Preliminary characterization of Borrelia burgdorferi CSF isolates. Infection 1991; 19: 287-288.

29. Stanek G, Jurkowitsch B, Köchl C, Burger I, Khanakha G. Reactivity of European and American isolates of Borrelia burgdorferi with different monoclonal antibodies by means of a microimmunoblot technique. International Journal of Medical Microbiology 1990; 272: 426-436.

30. Barbour AG, Schrumpf ME. Polymorphisms of major surface proteins of Borrelia burgdorferi. Zentralblatt für Bakteriologie, Mikrobiologie und Hygiene [A] 1986; 263: 83-91.

31. Canina MM, Nato F, du Merle L, Mazie JC, Baranton G, Postic D. Monocional antibodies for identification of Borrelia afzeliisp. nov. associated with late cutaneous manifestations of Lyme borreliosis. Scandinavian Journal of Infectious Diseases 1993; 25: 441-448. 
32. Kramer MD, Schaible U, Wallich R, Mater SE, Petzoldt D, Simon MM. Characterization of Borrelia burgdorferi associated antigens by monoclonal antibodies. Immunobiology 1990; 181: 357-366.

33. LeFebvre RB, Lane RS, Perng GC, Brown JA, Johnson RC. DNA and protein analysis of tick-derived isolates of Borrelia burgdorferi from California. Journal of Clinical Microbiology 1990; 28: 700-707.

34. Baranton G, Postic D, Saint Girons I, Boerlin P, Piffaretti JC, Assous M, Grimont PA. Delineation of Borrelia burgdorferi sensu stricto, Borrelia garinii sp. nov., and Group VS461 associated with Lyme borreliosis. International Journal of Systematic Bacteriology 1992; 42: 378-383.

35. Postic D, Edlinger C, Richaud C, Grimont F, Dufresne Y, Perolat P, Baranton G, Grimont PA. Two genomic species in Borrelia burgdorferi. Research in Microbiology 1990, 141: 465-475.

36. Adam T, Gassmann GS, Rasiah C, Göbel UB. Phenotypic and genotypic analysis of Borrelia burgdorferi isolates from various sources. Infection and Immunity $1991 ; 59: 2579-2585$.

37. Marconi RT, Garon CF. Phylogenetic analysis of the genus Borrelia: a comparison of North American and European isolates of Borrelia burgdorferi. Journal of Bacteriology 1992; 174: 241-244.

38. Rosa PA, Hogan D, Schwan TG. Polymerase chain reaction analysis identify two distinct classes of Borrelia burgdorferi. Journal of Clinical Microbiology 1991; 29: 524-532.

39. Welsh J, Pretzman C, Postic D, Saint Girons I, Baranton G, McClelland M. Genomic fingerprinting by arbitrarily primed polymerase chain reaction resolves Borrelia burgdorferi into three phyletic groups. International Journal of Systematic Bacteriology 1992; 42: 370-377.

40. BarbourAG. Plasmid analysis of Borrelia burgdorferi, the Lyme disease agent. Journal of Clinical Microbiology 1988; 26: 475-478.

41. Stalhammar-Carlemalm M, Jenny E, Gern L, Aeschlimann A, Meyer J. Plasmid analysis and restriction fragment length polymorphisms of chromosomal DNA allow a distinction between Borrelia burgdorferi strains. Zentralblatt für Bakteriologie 1990; 274: 28-39.

42. Hovind-Hougen K. Ultrastructure of spirochetes isolated from Ixodes ricinus and Ixodes dammini. Yale Journal of Biology and Medicine 1984; 57: 543-548.

43. Wilske B, Schierz G, Preac-Mursic V, Weber KK, Pfister HW, Einhäupl K. Serological diagnosis of erythema migrans disease and related disorders. Infection 1984; 12: 331-337.

44. Barbour AG. Isolation and cultivation of Lyme disease spirochetes. Yale Journal of Biology and Medicine 1984; 57: 521-525.

45. Grimont F, Grimont PA. Ribosomal ribonucleic acid gene restriction patterns as potential taxonomic tools. Annales de l'Institute Pasteur 1986; 137B: 165175.

46. Gassmann GS, Kramer M, Göbel UB, Wallich R. Nucleotide sequence of a gene encoding the Borrelia burgdorferi flagellin. Nucleic Acids Research 1989; 17: 3590 .

47. Craft JE, Grodzicki RL, Steere AC.Antibody response in Lyme disease: evaluation of diagnostic tests. Journal of Infectious Diseases 1984; 149: 789-795. 
48. Laemmli UK. Cleavage of structural proteins during the assembly of the head of bacteriophage T4. Nature 1970; 227: 680-685.

49. Towbin H, Staehelin J, Gordon J. Electrophoretic transfer of proteins from polyacrylamide gels to nitrocellulose sheets: procedure and some applications. Proceedings of the National Academy of Sciences of the USA 1979; 76: 4350-4354.

50. Barbour AG, Hayes SF, Heiland RA, Schrumpf ME, Tessier SL. A Borreliaspecific monoclonal antibody binds to a flagellar epitope. Infection and Immunity 1986; 52: 549-554.

51. Barbour AG, Tessier SL, Todd WJ. Lyme disease spirochetes and ixodid tick spirochetes share a common surface antigenic determinant defined by a monoclonal antibody. Infection and Immunity 1983; 41: 795-804.

52. Barbour AG, Tessier SL, Hayes SF. Variations in major surface proteins of Lyme disease spirochetes. Infection and Immunity 1984; 45: 94-100.

53. Wilske B, Preac-Mursic V, Jauris S, HofmannA, Pradel I, Soutschek E, Schwab E, Will G, Wanner G. Immunological and molecular polymorphisms of OspC, an immunodominant major outer surface protein of Borrelia burgdorferi. Infection and Immunity 1993; 61: 2182-2191.

54. Wallich R, Helmes C, Schaible UE, Lobet $Y$, Moter SE, Kramer MD, Simon MM. Evaluation of genetic divergence among Borrelia burgdorferi isolates by use of OspA, fla, HSP60, and HSP70 gene probes. Infection and Immunity 1992; 60: 4856-4866.

55. Casjens $S$, Mun Huang W. Linear chromosomal physical and genetic map of Borrelia burgdorferi, the Lyme disease agent. Molecular Microbiology 1993; 8: 967-980.

56. Peter O, Bretz AG. Polymorphism of outer surface proteins of Borrelia burgdorferi as a tool for classification. Zentralblatt für Bakteriologie 1992; 277: 2833.

57. Schwan TG, Burgdorfer W. Antigenic changes of Borrelia burgdorferi as a result of in vitro cultivation. Journal of Infectious Diseases 1987; 156: 852853.

58. Wilske B, Preac-Mursic V, Schierz G, Busch KV. Immunochemical and immunological analysis of European Borrelia burgdorferi strains. Zentralblatt für Bakteriologie, Mikrobiologie und Hygiene [A] 1986; 263: 92-102.

59. Simpson WJ, Garon CF, Schwan TG. Borrelia burgdorferi contains repeated DNA sequences that are species specific and plasmid associated. Infection and Immunity 1990; 58: 847-853.

60. Hughes CA, Johnson RC. Methylated DNA in Borrelia species. Journal of Bacteriology $1990 ; 172: 6602-6604$.

61. Cluss RG, Boothby JT. Thermoregulation of protein synthesis in Borrelia burgdorferi. Infection and Immunity 1990; 58: 1038-1042. 


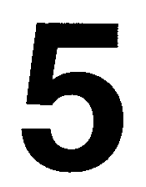

\section{EVALUATION OF NINE SEROLOGICAL TESTS FOR DIAGNOSIS OF LYME BORRELIOSIS}

MKE Nohlmans ${ }^{1}$, AAM Blaauw², AEJM van den Bogaard', CPA van Boven ${ }^{1}$

1 Department of Medical Microbiology, State University of Limburg, Maastricht;

2 Department of Internal Medicine, Division of Rheumatology, University Hospital Maastricht, Maastricht, The Netherlands.

Reprinted by permission of the European Journal of Clinical Microbiology \& Infectious Diseases 1994; 13: 394-400. 


\section{EVALUATION OF NINE SEROLOGICAL TESTS FOR DIAGNOSIS OF LYME BORRELIOSIS}

\section{ABSTRACT}

Two hundred serum specimens including 13 sera from patients with early Lyme borreliosis, 21 patients with late Lyme borreliosis, 15 rheumatoid factor positive sera, 31 sera from patients with syphilis and 84 sera from healthy controls were used to evaluate the following assays for the detection of antibodies to Borrelia burgdorferi: two in-house enzyme immunoassays (EIAs), two in-house immunofluorescent antibody assays (IFAs), a commercial haemagglutination assay (HA) (Diagast) and four commercial ElAs (Dako, Diamedix, Whittaker Bioproducts, Diagast). In early and late Lyme borreliosis sera sensitivity ranged from $8 \%$ to $62 \%$ and from $62 \%$ to $86 \%$ respectively. With the exception of the Dako EIA, which was significantly more sensitive in early Lyme borreliosis $(62 \%)$ than the Diagast HA $(8 \%)$ $(p=0.05)$, differences in sensitivity were not significant. In healthy controls the specificity was $\geq 95 \%$ for all tests. Taking into account sensitivity, specificity, intra-test and inter-test precision, ease of performance and cost, the Dako EIA and Diamedix EIA were shown to be good alternatives to the inhouse EIA and in-house IFA. Because of its low sensitivity in diagnosis of both early and late Lyme borreliosis, use of the Diagast HA should be discouraged.

\section{INTRODUCTION}

Since the discovery in 1982 of Borrelia burgdorferi as the causative agent of Lyme borreliosis (1) and subsequent awareness of the global distribution of this disease (2), serological tests for diagnosis of the disease have been given much attention. Several factors have contributed to this development. Firstly, Lyme borreliosis is a multisystem infectious disease and by virtue of its wide range of clinical manifestations may mimic several other diseases $(3,4)$. Diagnosing Lyme borreliosis purely on clinical and/or anamnestic grounds may be difficult, especially in the absence of erythema migrans (EM) which is only present in about $60 \%$ of patients $(3,4)$. Secondly, the standard methods for confirming the diagnosis of a bacterial infection, i.e. isolation or direct visualization of the causative agent, and methods such as antigen detection, T-lymphocyte assay or polymerase chain reaction are either not sensitive enough or not readily available in clinical practice (5-13). However, there are several other problems in the diagnosis of Lyme borreliosis. The antibody response in Lyme borreliosis is slow and IgM antibodies may not be detectable until six weeks after onset of the disease. Pro- 
duction of IgG antibodies may follow within a few weeks but may not reach a peak until months or years after the onset of the disease (4). Antibiotic therapy given during early Lyme borreliosis may hamper the development of antibodies (4). False positive results may occur due to cross-reactivity with other bacteria, mainly other Borrelia species and treponemas, or the presence of viral infections or rheumatic disorders (4). Furthermore, the occurrence of asymptomatic Lyme borreliosis is well documented (14-17). To improve sensitivity, especially in early disease, and to reduce cross-reactivity, several methods have been advocated. These include the use of purified outer membrane or flagella antigens and the preadsorption of samples with Treponema phagedenis or other bacterial antigens (18). However, experience so far has been variable and none of the currently available diagnostic methods including immunofluorescent antibody assays (IFA), enzyme immunoassay (EIA), haemagglutination assays (HA) and Western blot have been standardized with regard to techniques, antigen preparations, reagents or even the definition of what constitutes a positive result (18).

In the present study the performance and costs of five commercial assays in comparison with four in-house assays were evaluated using different groups of clinically well characterized sera.

\section{MATERIALS AND METHODS}

\section{Sera}

Two hundred serum samples which were carefully selected on clinical grounds were divided into six categories according to their origin from patients with early Lyme borreliosis, late Lyme borreliosis, asymptomatic Lyme borreliosis, rheumatoid factor or syphilis and healthy controls. Of the 13 patients in the early Lyme borreliosis group, all of whom had EM, B. burgdorferi was isolated from the skin lesions in three patients. Of the 21 patients in the late Lyme borreliosis group, 4 had arthralgia, 15 arthritis and 2 acrodermatitis chronica atrophicans following EM. The third group comprised 36 Swiss cross-country runners, a high-risk group for Lyme borreliosis because of regular exposure to Ixodes ricinus. The sera were kindly provided by Fahrer et al. (14). All 36 cross-country runners were asymptomatic without any history of Lyme borreliosis but had high levels of antibodies to $B$. burgdorferi as determined by a whole-cell IgG EIA (14). In the remaining three groups 15 sera were obtained from patients with RF-positive rheumatoid arthritis; 31 sera from syphilitic patients positive in the VDRL test, TPHA and fluorescent treponemal antibody-absorption test; and 84 control sera from healthy Dutch volunteers without any history of Lyme borreliosis. All sera from patients with Lyme borreliosis were also tested for rheumatoid factor (RF), and nonspecific and specific syphilis antibodies. 


\section{In-house Enzyme Immunoassays}

Whole-cell sonicate preparation of B. burgdorferi B31 (ATCC 35210) and ElA were performed essentially as described by Craft et al. (19). The protein concentration of the antigen was determined by the Bio-Rad, protein assay (Bio-Rad Laboratories, Germany). The optimal concentration of $B$. burgdorferi antigen for coating the microdilution plates, and the appropriate serum and conjugate dilutions were determined by checkerboard titrations using low and high titred reference sera (kindly provided by B. Wilkske, Munich, Germany). Microdilution plates (PETG 6595, Costar, The Netherlands) were coated with $200 \mu \mathrm{l}$ of a solution of $0.12 \mathrm{mg} / \mathrm{L}$ Borrelia antigen in $0.05 \mathrm{M}$ sodium carbonate buffer $(\mathrm{pH}$ 9.6). For the in-house EIA without adsorption of sera, serum specimens were diluted 1:100 in PBS containing $0.05 \%$ Tween and $0.02 \% \mathrm{NaN}_{3}$ (PBS-TA), and for the in-house EIA with adsorption, serum specimens were adsorbed (1:16) with $T$. phagedenis antigen (ORMA 14/15, Behring, Germany) at $37^{\circ} \mathrm{C}$ for $30 \mathrm{~min}$. and then diluted 1:6.25 in PBS-TA. From each diluted serum $150 \mu \mathrm{l}$ was added to the wells in duplicate. Positive and negative control sera were included on each plate. After $3 \mathrm{~h}$ of incubation at $37^{\circ} \mathrm{C}$ the plates were washed four times with PBS-TA and incubated with $150 \mu \mathrm{l}$ of alkaline phosphatase-tagged antihuman IgG diluted 1:600 (A 5403, Sigma, USA) at $37^{\circ} \mathrm{C}$ for $1 \mathrm{~h}$. The plates were washed as described above and incubated with $150 \mu$ l of a solution of $1 \mathrm{mg} / \mathrm{ml}$ para-nitrophenyl phosphate (104, Sigma) in carbonate buffer containing $0.001 \mathrm{M} \mathrm{MgCl}_{2}(\mathrm{pH} 9.8)$ at $37^{\circ} \mathrm{C}$ for $30 \mathrm{~min}$. The enzymatic reaction was stopped by the addition of $50 \mu$ of $5 \mathrm{~N} \mathrm{NaOH}$ and the optical density (OD) was measured at $405 \mathrm{~nm}$ in a Titertek Multiscan (Eflab Oy, Finland). For interpretation of test results, cut-off values of 0.35 OD (EIA without adsorption) and 0.17 OD (EIA with adsorption) were calculated. These OD values were two standard deviations above the mean values for 128 sera from healthy Dutch persons and correlated with the $95 \%$ specific diagnostic cut-off values based on these results.

\section{In-house Immunofluorescence Assays}

Antigen preparation of $B$. burgdorferi B31 was performed essentially as described by Craft et al. (19). The washed spirochete pellet was diluted in PBS containing $5 \mathrm{mM} \mathrm{MgCl}$ (PBS- $\mathrm{MgCl}_{2}$ ) to a final concentration of $10^{6}$ spirochetes $/ \mathrm{ml}$ (examined by dark field microscopy) in a counting chamber (748 Hawksley B.S., UK). Multitest slides $(12 \times 4 \mathrm{~mm}$. Flow Laboratories, UK) were coated with $7 \mu \mathrm{l}$ of this suspension, allowed to dry at room temperature and fixed with cold acetone for $10 \mathrm{~min}$. After Giemsa staining each spot showed approximately 100 to 150 spirochetes per high power field when examined by dark field microscopy (ocular magnification 12x, objective 40x). The slides were stored at $-70^{\circ} \mathrm{C}$ until use.

The IFAs were performed essentially as described by Wilske at al. (20). Two-fold dilutions of sera were tested, beginning with a 1:16 dilution. Sera were diluted for the IFA without adsorption in PBS- $\mathrm{MgCl}_{2}$ whereas for the IFA with adsorption, sera were first adsorbed 1:16 with $T$. phagedenis anti- 
gen (Behring) at $37^{\circ} \mathrm{C}$ for $30 \mathrm{~min}$. Slides were stained with fluorescein-labelled anti-human IgG 1:300 (F5512, Sigma). Positive and negative control sera (kindly provided by $B$. Wilkske) were included on each slide. The negative control serum had to be negative at a dilution of 1:16 both in the IFA without adsorption and in the IFA with adsorption of sera. The positive control serum had to yield a titre of $\geq 1024$ (IFA without adsorption) or $\geq 512$ (IFA with adsorption). The titre of a serum was defined as the highest dilution in which more than $50 \%$ of the borreliae per field were luminescent. Titres of $\geq 256$ and $\geq 64$ were considered positive for the IFA without adsorption and IFA with adsorption of sera, respectively. These titres constituted the 95\% specific diagnostic cut-off value for 100 Dutch blood donors.

\section{Commercial Enzyme Immunoassays}

The following kits were evaluated: the Lyme Borreliosis EIA kit (Dako A/S, Denmark), the Lyme Disease Microassay (Diamedix, USA), the Lyme Stat Test kit (Whittaker Bioproducts, USA) and the Elilyme G (Diagast, France). These four systems were used according to the instructions of the manufacturers (Table 1). All sera and controls were tested in duplicate. For calculations of sensitivity and specificity borderline results were considered positive.

\section{Commercial Haemagglutination Assay}

The Lymag haemagglutination assay (Diagast) was used according to the instructions of the manufacturer.

\section{Statistical Analysis}

The chi-square test was used to test for significant differences between groups. A probability value $<0.05$ was considered statistically significant.

\section{RESULTS}

Sera from all patients with Lyme borreliosis were negative for RF, and for specific and nonspecific syphilis antibodies in the VDRL test and TPHA.

\section{Sensitivity and Specificity}

The results of the nine assays are presented in Table 2. None of the three early Lyme borreliosis sera from patients who had $B$. burgdorferi isolated from their EM lesions was positive in the two in-house IFAs or Diagast HA. One was positive in the in-house EIA without adsorption, Whittaker EIA and Diagast EIA, two were positive in the in-house EIA with adsorption and Diamedix EIA, and all three were positive in the Dako EIA. Of the remaining ten early Lyme borreliosis sera, five were positive in the two in-house EIAs, 


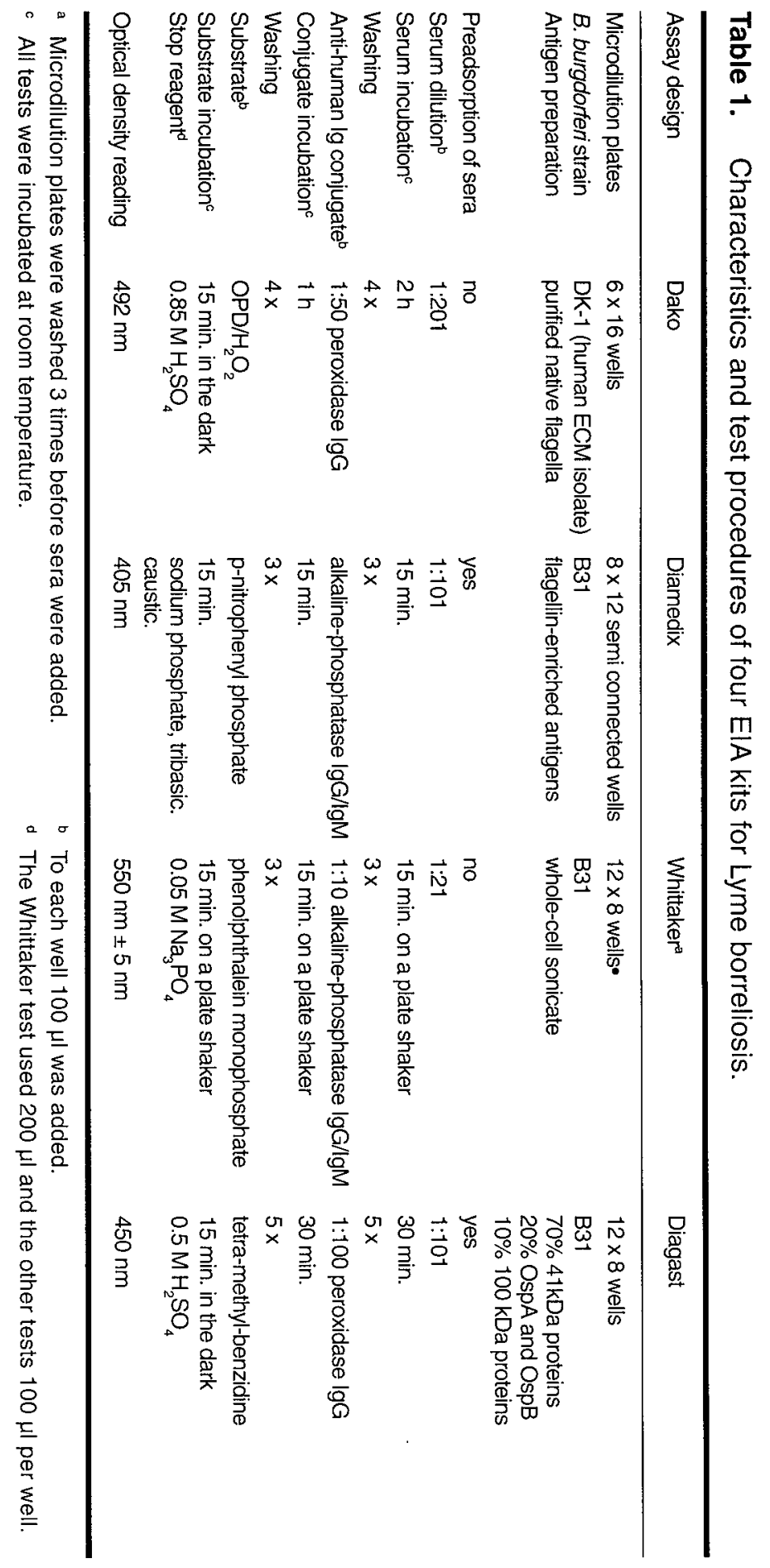


Dako EIA and Diagast EIA, four were positive and one was borderline in the Diamedix EIA, four were positive in the two in-house IFAs, and two were positive and one was borderline in the Whittaker EIA. Of the 21 late Lyme borreliosis sera, 13 of 15 sera from patients with arthritis were positive in all four in-house assays and in the Dako, Diamedix and Diagast EIA, ten were positive in the Whittaker EIA and nine were positive in the Diagast HA. Three of the four sera from patients with arthralgia were positive in all assays except the Diagast HA which only showed two sera to be positive. The two sera from patients with acrodermatitis chronica atrophicans were positive in all nine assays. With the exception of the Dako EIA, which in early Lyme borreliosis was significantly more sensitive $(62 \%)$ than the Diagast $H A(8 \%)(p<0.05)$, differences in sensitivity in early and late Lyme borreliosis were not significant. In sera from the asymptomatic Lyme borreliosis group the number of positive test results obtained with the Diagast HA (10/36) and Whittaker EIA (24/36) was significantly lower than that obtained with the other assays $(33 / 36$ to $36 / 36)(p<0.05)$. The specificity values in $R F$ positive sera and healthy controls did not differ significantly. However, in syphilitic sera the specificity of the in-house EIA without adsorption (29\%) was significantly $(p<0.05)$ lower than that of the other eight assays $(68 \%$ to $100 \%)$, and the specificity of the Dako EIA (68\%) was significantly lower than that of the Diagast HA $(97 \%)$, Diamedix ElA (97\%), Whittaker EIA (100\%) and Diagast EIA $(97 \%)(p<0.05)$.

\section{Mean Index Values}

To further compare the four commercial and the two in-house EIAs, mean index values per sera category were calculated by dividing test results by their corresponding cut-off value (Table 3 ). In general, mean index values were directly proportional to sensitivity and specificity. For all six EIAs, mean index values in late Lyme borreliosis were more than twice values in early Lyme borreliosis, and mean index values in late Lyme borreliosis but not in early Lyme borreliosis, were significantly higher than values in RF positive, syphilitic or healthy control sera $(p<0.05)$. The highest mean index value for both early and late Lyme borreliosis sera in combination with the lowest values for RF positive, syphilitic and healthy control sera was seen in the Diamedix EIA.

\section{Precision}

Precision profiles were constructed in order to determine the reliance which could be placed on a single test result. Table 4 presents the average withinrun and run-to-run variations of the six EIAs evaluated. The Dako EIA and Diamedix EIA showed significantly lower within-run variations, and the Whittaker EIA showed significantly higher run-to-run variation compared to the other EIAs evaluated $(p \leq 0.05)$. 


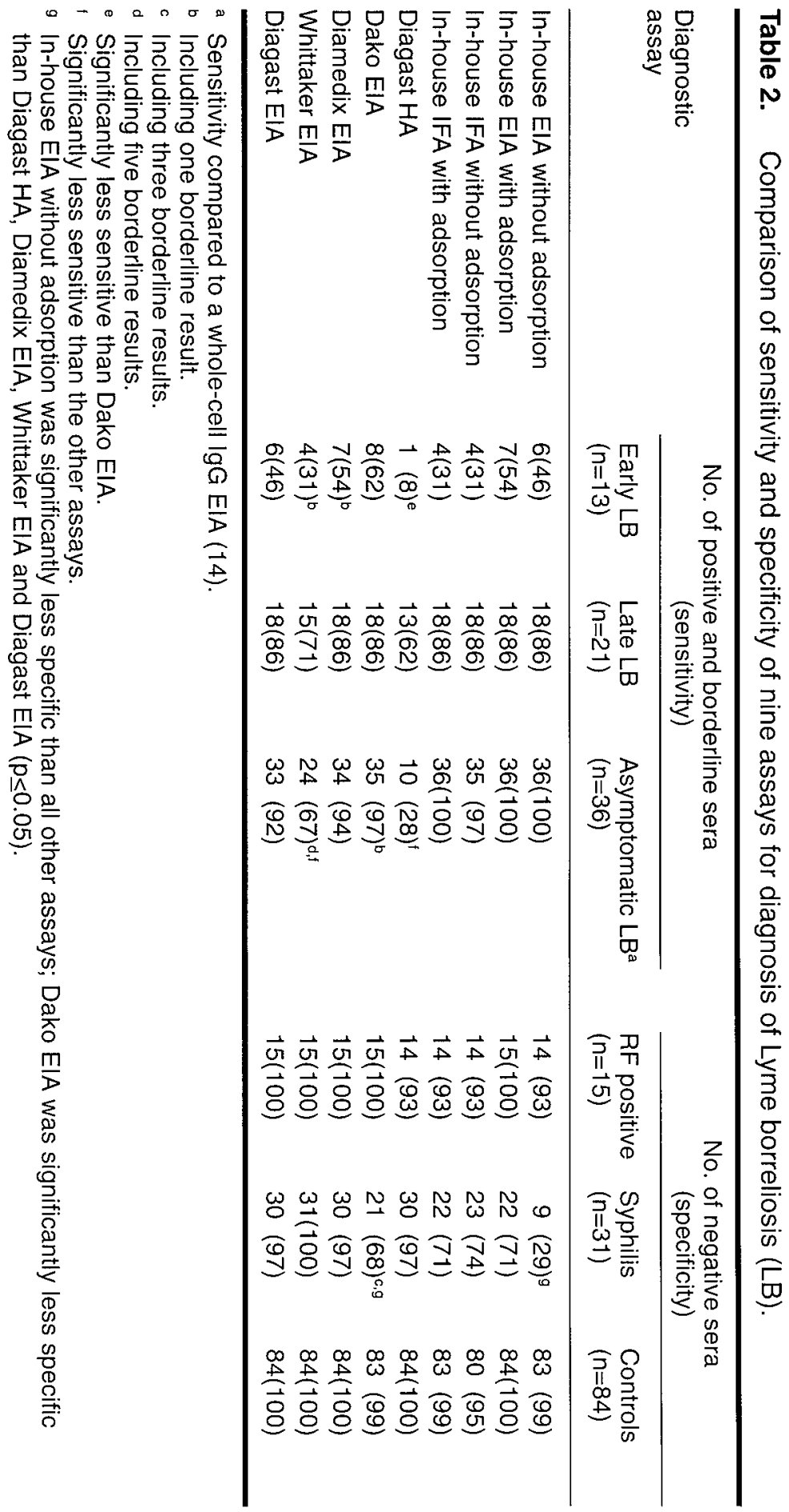




\section{Costs Calculated}

The Dako EIA, Diamedix EIA, Whittaker EIA and Diagast EIA test kits were compared with regard to costs. The figures in Table 5 represent the relative costs per test for different numbers of sera tested per run using the Dako EIA in one test per run as index. Calculations were based on recommended retail prices for 96-well kits. In general, the costs for the Whittaker EIA and Diagast EIA were higher, and the costs for the Diamedix EIA lower, compared to the Dako ElA.

\section{DISCUSSION}

In sera from early and late Lyme borreliosis patients, the sensitivity of the assays tested ranged from $8 \%$ to $62 \%$ and from $62 \%$ to $86 \%$ respectively, but with the exception of the Dako EIA, which was significantly more sensitive in early Lyme borreliosis $(62 \%)$ than the Diagast HA $(8 \%)(p=0.05)$, differences in sensitivity were not significant. The low sensitivity of the Diagast $\mathrm{HA}$ in both early and late Lyme borreliosis ( $8 \%$ and $62 \%$ ) and the relatively low sensitivity of the IFAs in early Lyme borreliosis compared to the EIAs ( $31 \%$ versus $\geq 46 \%$ ), is in agreement with the findings of others $(19,21-24)$. The inclusion of sera from asymptomatic Swiss cross-country runners in this study may raise questions about the reliability of these sera in the evaluation of serological assays for Lyme borreliosis. However, Fahrer et al. (14), who supplied the sera from the asymptomatic Lyme borreliosis group, did not find that seropositivity in these sera constituted false positive results. Furthermore, several other studies, including an investigation of our own in The Netherlands, have shown that asymptomatic infections with $B$. burgdorferi are common in individuals with high exposure to ticks and that clinical manifestations of Lyme borreliosis in these populations is infrequent (14-17). However, as demonstrated by the significantly lower positivity rates of the Diagast HA and Whittaker EIA in asymptomatic Lyme borreliosis (10/ 36 and 24/36) compared to the remaining seven assays $(\geq 33 / 36)(p \leq 0.05)$, it is of primary importance to consider the serological method used when comparing results of different studies.

Several studies have indicated that reduction of cross-reactivity is possible by preadsorption of sera $(20,25,26)$. This may explain why the Diagast HA, Diamedix EIA and Diagast EIA, all three of which used an adsorbent, were significantly more specific in syphilitic sera than the Dako EIA, which used no adsorbent ( $\geq 97 \%$ versus $68 \%)(p<0.05)$. With regard to our in-house EIA and IFA, preadsorption of sera was less effective, probably because we did not test whether the adsorption eliminated all cross-reacting antibodies against the adsorbent used (20).

Reports have been published on the use of purified antigens to reduce crossreactivity and to increase sensitivity (27-30). Of the six ElAs evaluated, Dako, Diamedix and Diagast used purified antigens. In agreement with the findings of Hansen et al. (30), the Dako ElA showed an increase in sensitivity 


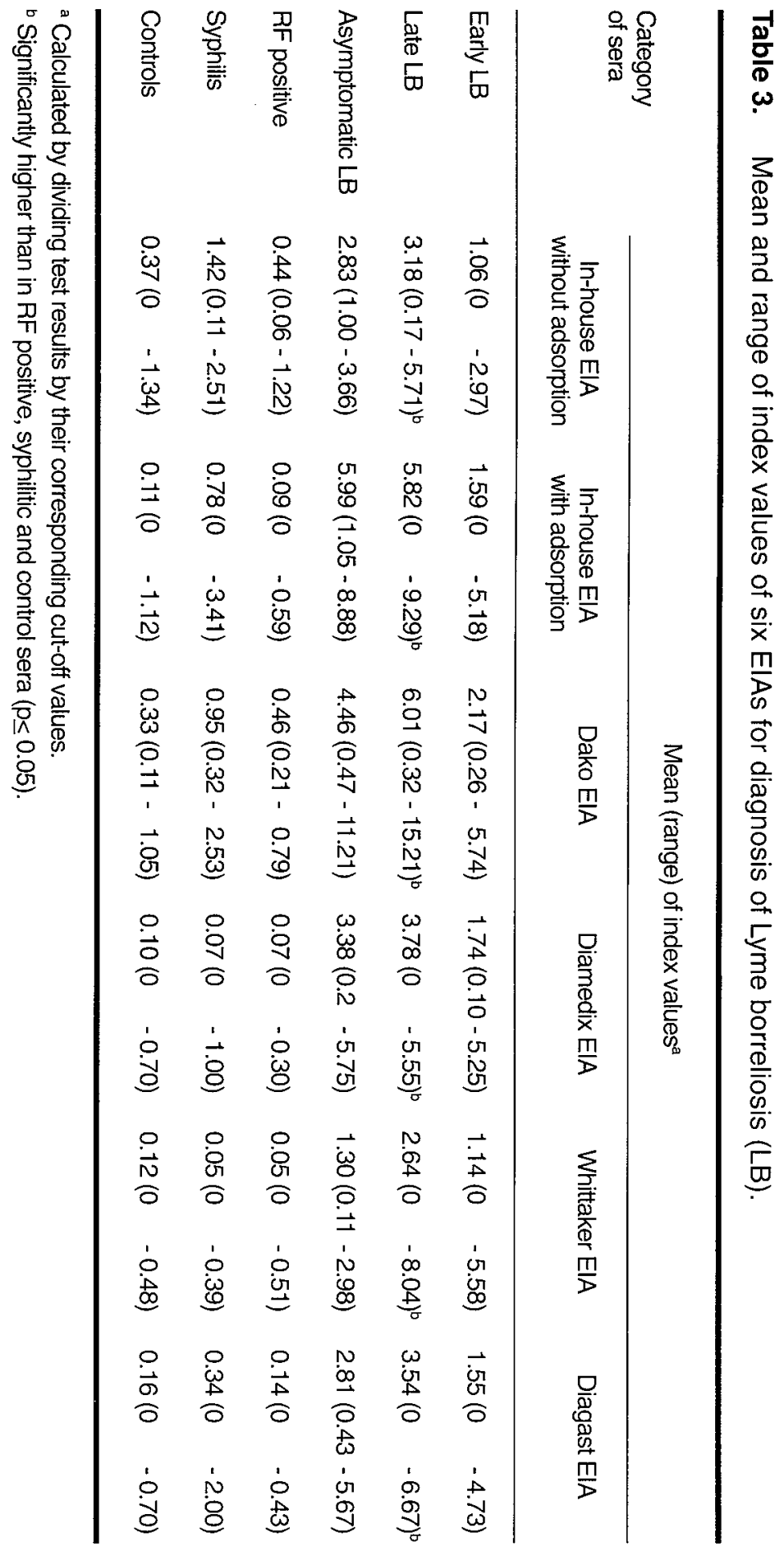


Table 4. Variation in the performance of six EIAs for diagnosis of Lyme borreliosis.

\begin{tabular}{lcc}
\hline \multirow{2}{*}{ EIA } & $\begin{array}{c}\text { Average percentage of coefficient of } \\
\text { variation (range) }\end{array}$ \\
\cline { 2 - 3 } & Within-run & Run-to-run \\
\hline In-house without adsorption & $8(0-100)$ & $11(8-16)$ \\
In-house with adsorption & $9(0-100)$ & $12(8-17)$ \\
Dako & $5(0-66)^{\mathrm{a}}$ & $12(10-16)$ \\
Diamedix & $3(0-17)^{\mathrm{a}}$ & $11(5-17)$ \\
Whittaker & $14(0-100)$ & $23(13-32)^{\mathrm{b}}$ \\
Diagast & $10(0-80)$ & $12(10-14)$ \\
\hline
\end{tabular}

a Significantly lower compared to the remaining assays $(p \leq 0.05)$.

b Significantly higher compared to the remaining assays $(p \leq 0.05)$.

Table 5. Comparison of relative costs for four ElA kits for diagnosis of Lyme borreliosis. The Dako EIA in one test served as index. Calculations were based on recommended retail prices for 96well kits.

No. of sera tested per run

Relative costs per serum

Dako Diamedix Whittaker Diagast

\begin{tabular}{ccccc}
1 & 1.00 & 0.32 & 1.01 & 1.10 \\
3 & 0.34 & 0.16 & 0.34 & 0.37 \\
5 & 0.20 & 0.13 & 0.40 & 0.23 \\
10 & 0.10 & 0.11 & 0.21 & 0.23 \\
15 & 0.13 & 0.10 & 0.21 & 0.23 \\
20 & 0.10 & 0.09 & 0.21 & 0.17 \\
\hline
\end{tabular}


in early Lyme borreliosis (from $46 \%$ to $62 \%$ ) as well as an approximately $50 \%$ increase in specificity compared with our in-house whole-cell EIA without adsorption. The Diamedix and Diagast EIA both use flagellar-enriched fractions. Compared with the in-house EIA with adsorption, the Diamedix EIA showed similar sensitivity (54\%) in early Lyme borreliosis whereas the Diagast EIA was less sensitive (46\%).

The Diamedix and Whittaker EIA both detected IgG and IgM antibodies simultaneously but the sensitivity, even of the Diamedix EIA which uses flagellar-enriched antigens and thus theoretically should detect IgM antibodies better than the Whittaker EIA, did not exceed the sensitivity of the Dako EIA, which only detects IgG antibodies. In this study we did not determine levels of IgM antibodies individually, but there are reports that IgM can more readily be detected by a flagella-enriched IgM EIA than by an IgG/lgM EIA (31).

Although the Whittaker EIA and in-house EIAs all used whole-cell sonicates of the B31 strain, differences were observed in sensitivity and specificity. This finding may be partly explained by differences in the culture medium and conditions, number of passages and methods used for antigen preparation $(32,33)$.

Our results indicating a higher sensitivity of the Dako EIA in early Lyme borreliosis compared to the Diamedix EIA, as well as high specificity of the Diamedix EIA are in agreement with findings reported in the literature $(21,34)$. Serological tests for Lyme borreliosis are not yet standardized and considerable intra-test and inter-test variation has been reported $(35,36)$. Our calculations showed that intra-test precision of the Dako EIA (95\%) and Diamedix EIA (97\%) was significantly higher, and inter-test precision of the Whittaker EIA significantly lower than that of other assays. A commercial EIA may be an attractive alternative to the development of an in-house assay, especially when the cost per patient serum is relatively low. A comparison of cost per test using the Dako ElA as index showed that the Whittaker EIA and Diagast EIA are relatively expensive and that the Diamedix is relatively cheap, especially when small numbers of sera have to be tested.

In conclusion, taking into account sensitivity, specificity, intra-test and intertest precision, ease of performance and cost, the Dako EIA and Diamedix EIA are good alternatives to the in-house EIA and in-house IFA. Due to their relatively low sensitivity in combination with relatively low intra-test and inter-test precision and relatively high cost, the Diagast EIA and Whittaker EIA are less useful. In view of its low sensitivity in both early and late Lyme borreliosis sera, use of the Diagast HA should be discouraged. 


\section{REFERENCES}

1. Burgdorfer W, Barbour AG, Hayes SF, Benach JL, Grunwaldt E, Davis JP. Lyme disease: a tickborne spirochetosis? Science 1982; 216: 1317-1319.

2. Liu HH. Lyme disease: epidemiology, diagnosis, and management. Delaware Medical Journal 1990; 62: 1351-1360.

3. Steere AC. Lyme disease. New England Journal of Medicine 1989; 321: $586-$ 596.

4. Rahn DW. Lyme disease: clinical manifestations, diagnosis, and treatment. Seminars in Arthritis and Rheumatism 1991; 20: 201-218.

5. Steere AC, Grodzicki RL, Kornblatt AN, Craft JE, Barbour AG, Burgdorfer W, Schmid GP, Johnson E, Malawista SE. The spirochetal etiology of Lyme disease. New England Journal of Medicine 1983; 308: 733-740.

6. Haupl T, Burmester GR. Klinik, Diagnostik und Therapie der Lyme-Borreliose. Zeitschrift für Ärztliche Fortbildung 1992; 86: 6-12.

7. Nadelman RB, Pavia CS, Magnarelli LA, Wormser GP. Isolation of Borrelia burgdorferi from the blood of seven patients with Lyme disease. American Journal of Medicine 1990; 88: 21-26.

8. de Koning J, Bosma RB, Hoogkamp-Korstanje JAA. Demonstration of spirochaetes in patients with Lyme disease with a modified silver stain. Journal of Medical Microbiology 1987; 23: 261-267.

9. Valesova M, Trnavsky K, Hulinska D, Alusik S, Janousek J, Jirous J. Detection of Borrelia in the synovial tissue from a patient with Lyme borreliosis by electron microscopy. Journal of Rheumatology 1989; 16: 1502-1505.

10. Banyas GT. Difficulties with Lyme serology. Journal of the American Optometric Association 1992; 63: 135-139.

11. Dattwyler RJ, Volkman DJ, Luft BJ, Halperin JJ, Thomas J, Golightly MG. Seronegative Lyme disease. Dissociation of specific T- and B- Iymphocyte responses to Borrelia burgdorferi. New England Journal of Medicine 1988; 319: 1441-1446.

12. Hyde FW, Johnson RC, White TJ, Shelburne CE. Detection of antigens in urine of mice and humans infected with Borrelia burgdorferi, etiologic agent of Lyme disease. Journal of Clinical Microbiology 1989; 27: 58-61.

13. Melchers W, Meis J, Rosa P, Claas E, Nohlmans L, Koopman R, Horrevorts A, Galama J. Amplification of Borrelia burgdorferi DNA in skin biopsies from patients with Lyme disease. Journal of Clinical Microbiology 1991; 29: 24012406.

14. Fahrer H, Sauvain MJ, van der Linden S, Zhioua E, Gern L, Aeschlimann A. Prävalenz der Lyme-Borreliose in einer schweizerischen Risikopopulation. Schweizerische Medizinische Wochenschrift 1988; 118: 65-69.

15. Huycke MM, D'Alessio DD, Marx JJ. Prevalence of antibody to Borrelia burgdorferi by indirect fluorescent antibody assay, ELISA, and Western immunoblot in healthy adults in Wisconsin and Arizona. Journal of Infectious Diseases 1992; 165: 1133-1137.

16. Gustafson R, Svenungsson B, Gardulf A, Stiernstedt G, Forsgren M. Prevalence of tick-borne encephalitis and Lyme borreliosis in a defined Swedish population. Scandinavian Journal of Infectious Diseases 1990; 22: 297-306. 
17. Nohlmans MKE, van den Bogaard AEJM, Blaauw AAM, van Boven CPA. Prevalentie van Lyme-borreliose in Nederland. Nederlands Tijdschrift voor Geneeskunde 1991; 135: 2288-2292.

18. Stiernstedt G, Dattwyler R, Duray PH, Hansen K, Jirous J, Johnson RC, Karlsson M, Preac-Mursic V, Schwan TG. Diagnostic tests in Lyme borreliosis. Scandinavian Journal of Infectious Diseases, Supplement 1991; 77: 136142.

19. Craft JE, Grodzicki RL, Steere AC. Antibody response in Lyme disease: evaluation of diagnostic tests. Journal of Infectious Diseases 1984; 149: 789-795.

20. Wilske B, Schierz G, Preac-Mursic V, Weber K, Pfister HW, Einhaupl K. Serological diagnosis of erythema migrans disease and related disorders. Infection 1984; 12: 331-337.

21. Melby K, Steinbakk M, Jensenius M, Figenschau KJ. Detection of serum antibodies against Borrelia burgdorferi with some commercially available serological tests. NIPH Annals 1990; 13: 37-41.

22. Cutler SJ, Wright DJM. Evaluation of three commercial tests for Lyme disease. Diagnostic Microbiology and Infectious Diseases 1990; 13: 271-272.

23. Stiernstedt G, Eriksson G, Enfors W, Jorbeck H, Svenungsson B, Skoldenberg $B$, Granstrom M. Erythema chronicum migrans in Sweden: clinical manifestations and antibodies to Ixodes ricinus spirochete measured by indirect immunofluorescence and enzyme-linked immunosorbent assay. Scandinavian Journal of Infectious Diseases 1986; 18: 217-224.

24. Sticht-Groh V, Martin R. Possible pitfalls of an indirect immunofluorescence assay as the sole serological test in the diagnosis of Lyme disease. European Journal of Clinical Microbiology and Infectious Diseases 1988; 7: 84-85.

25. Fawcett PT, Gibney KM, Rose CD, Klein JD, Doughty RA. Adsorption with a soluble $E$. coli antigen fraction improves the specificity of ELISA tests for Lyme disease. Journal of Rheumatology 1991; 18: 705-708.

26. Fawcett $\mathrm{PT}$, O'Brien AE, Doughty RA. An adsorption procedure to increase the specificity of enzyme-linked immunosorbent assays for Lyme disease without decreasing sensitivity. Arthritis and Rheumatism 1989; 32: 1041-1045.

27. Coleman JL, Benach JL. Isolation of antigenic components from the Lyme disease spirochete: their role in early diagnosis. Journal of Infectious Diseases 1987; 155: 756-765.

28. Grodzicki RL, SteereAC. Comparison of immunoblotting and indirect enzymelinked immunosorbent assay using different antigen preparations for diagnosing early Lyme disease. Journal of Infectious Diseases 1988; 157: 790-797.

29. Magnarelli LA, Andersson JF, Barbour AG. Enzyme-linked immunosorbent assay for Lyme disease: reactivity of subunits of Borrelia burgdorferi. Journal of Infectious Diseases 1989; 159: 43-49.

30. Hansen K, Hindersson P, Strandberg-Pedersen N. Measurement of antibodies to the Borrelia burgdorferi flagellum improves serodiagnosis in Lyme disease. Journal of Clinical Microbiology 1988; 26: 338-346.

31. Fister RD, Weymouth LA, McLaughlin JC, Ryan RW, Tilton RC. Comparative evaluation of three products for the detection of Borrelia burgdorferi antibody in human serum. Journal of Clinical Microbiology 1989; 27: 2834-2837. 
32. Putzker M, Mertes T, Faulde M, Sobe D. Gegenüberstellung der Exoproteinmuster dreier europäischer isolate von Borrelia burgdorferi. Vergleich von 14 kommerziell erhältlichen und einem selbst entwickelten und evaluierten ELISA für die serologische Diagnostik der Lyme-Borreliose. Laboratoriums-Medizin 1990; 14: 397-403.

33. Luft BJ, Jiang W, Munoz P, Dattwyler RJ, Gorevic PD. Biochemical and immunological characterization of the surface proteins of Borrelia burgdorferi. Infection and Immunity 1989; 57: 3637-3642.

34. Christenson VD, White DH. Evaluation of four commercially available ELISA assays for the serologic diagnosis of Lyme disease. Journal of Clinical Laboratory Analysis 1991; 5: 340-343.

35. Luger SW, Krauss E. Serologic tests for Lyme disease: interlaboratory variability. Archives of Internal Medicine 1990; 150: 761-763.

36. Schwartz BS, Goldstein MD, Ribeiro JMC, Schulze TL, Shahied SJ. Antibody testing in Lyme disease: a comparison of results in four laboratories. Journal of the American Medical Association 1989; 262: 3431-3434. 


\section{6}

\section{VALIDITY OF WESTERN IMMUNOBLOT FOR SEROLOGICAL DIAGNOSIS OF LYME BORRELIOSIS}

MKE Nohlmans', AAM Blaauw², MJG Luppes³, A'EJM van den Bogaard', JAA Hoogkamp-Korstanje ${ }^{4}$, CPA van Boven ${ }^{1}$

1 Department of Medical Microbiology, State University of Limburg, Maastricht;

2 Department of Internal Medicine, Division of Rheumatology, University Hospital Maastricht, Maastricht;

${ }^{3}$ Department of Statistical Methods, Statistics Netherlands, Heerlen;

4 Department of Medical Microbiology and Infectious Diseases, University Hospital Nijmegen, Nijmegen, The Netherlands. 


\section{VALIDITY OF WESTERN IMMUNOBLOT FOR SEROLOGICAL DIAGNOSIS OF LYME BORRELIOSIS}

\section{ABSTRACT}

Two hundred and nine serum samples including 31 sera from patients with early Lyme borreliosis, 48 sera from patients with late Lyme borreliosis, 86 sera from patients who regularly enter into the clinical differential diagnosis of Lyme borreliosis, and 44 sera from healthy controls were used to determine the validity of a whole-cell sonicate $\operatorname{lgG}$ Western immunoblot as a specific confirmatory test for Lyme borreliosis. Based on logistic regression analysis using $\mathrm{kDa}$ ranges rather than individual $\mathrm{kDa}$ band values as independent variables, Western immunoblot significantly reduced the number of false-positive whole-cell IgG EIA results in healthy controls and in patients without Lyme borreliosis (43\% versus $10 \%$ ). In patients who may enter into the differential diagnosis of Lyme borreliosis Western immunoblot reduces false positive ElA results from $29 \%$ to $13 \%$. The sensitivity of Western immunoblot was comparable to EIA ( $63 \%$ versus $70 \%$ ) but the correlation between Western immunoblot and EIA in patients with Lyme borreliosis was only 0.41 . The use of Western immunoblot as a confirmatory test or an alternative to EIA cannot be recommended, since it would not solve the problems of interpretation of Lyme serology that confronts the clinician.

\section{INTRODUCTION}

Lyme borreliosis is a multisystem infectious disease with a broad range of clinical manifestations which can mimic several other disorders involving the skin, joints, nervous system and heart $(1,2)$. Hence, there is a need for highly sensitive and specific laboratory tests to confirm the clinical diagnosis. Isolation or direct visualisation of the causative agent, Borrelia burgdorferi, or antigen detection, T-lymphocyte assay and polymerase chain reaction (PCR) are either insensitive, laborious and time-consuming or not readily available in clinical practice (3-11). Therefore, serology is the most practical method for establishing the microbiological diagnosis and the most commonly used tests are enzyme immunoassay (EIA) and immuno-fluorescent antibody assay (IFA) (1217). However, these tests have often been insufficient for diagnosing early Lyme borreliosis and also yield false positive results due to cross-reactivity with other bacteria, mainly other Borrelia species and treponemas, or to viral infections or rheumatic disorders (2,17-21). Although the performance of EIA and IFA can be improved by using purified antigens, and/or by preadsorption of serum sam- 
ples with Treponema phagedenis and other bacterial antigens $(17,22)$, this does not entirely eliminate the problem.

The antibody response to $B$. burgdorferi has been analysed by Western immunoblot (23-29). The early response is directed against a limited number of antigens, primarily the $41 \mathrm{kDa}$ flagellar antigen and low molecular mass proteins in the $20-25 \mathrm{kDa}$ OspC region. As the disease progresses patients produce antibodies against an increasing number of both specific and nonspecific borrelial antigens including the 60-75 kDa heat-shock proteins, the 80-100 kDa protoplasmatic cylinder protein, the 30-33 kDa OspA and the 34-36 kDa OspB. The interpretation of Western immunoblot band patterns is controversial. It is not clear whether the criteria for positivity should be based on the number of bands, the type of bands, or the staining intensities of bands. Some investigators have found poor specificity of Western immunoblot (30), while others have reported immunoblot to be highly specific $(24,26,28,29)$. The main objective of the present study was to establish the validity of Western immunoblot as a specific confirmatory test for Lyme borreliosis. The sera used in this study were obtained from clinically well defined cases of Lyme borreliosis, patients who regularly enter into the clinical differential diagnosis of Lyme borreliosis, and healthy controls.

\section{MATERIALS AND METHODS}

\section{Patients and Controls}

Two hundred and nine clinically well defined serum samples were divided into four categories according to their origin from patients with early Lyme borreliosis $(n=31)$, late Lyme borreliosis $(n=48)$, patient controls $(n=86)$ and healthy controls $(n=44)$. All 209 sera had been used in previous studies and had been tested in our in-house whole-cell sonicate IgG ElA as described elsewhere $(17,31,32)$. In the early and late Lyme borreliosis groups as much EIA negative sera as available were included and in the patient and healthy control groups, as much EIA positive sera as available were included. Table 1 summarizes the characteristics of each of the four study groups. Patients with early and late Lyme borreliosis met the case definition (of the Centres for Disease Control and Prevention) for public health surveillance. (33). In these groups respectively 15 and 9 sera were negative by EIA. The patient control group comprised patients with rheumatoid factor (RF) positive rheumatoid arthritis $(n=21)$, ankylosing spondylitis $(n=18)$, psoriatic arthritis $(n=9)$, reactive arthritis $(n=4)$, systemic lupus erythematosus $(n=5)$, arthritis of unknown origin $(n=9)$, and patients with syphilis $(n=20)$ who were positive by the Venereal Disease Research Laboratory (VDRL), Treponema pallidum haemagglutination assay (TPHA) and fluorescent treponemal antibody-absorption test (FTA-ABS). In the patient control group, a total of 25 sera had positive serology by EIA. The fourth group consisted of 44 sera from healthy Dutch volunteers without any history suggesting Lyme borreliosis. Thirty one out of these sera had positive serology by EIA. 
Table 1. Characteristics of 209 sera used for Western immunoblot evaluation.

\begin{tabular}{lcc}
\hline Study group & $\begin{array}{c}\text { No. of sera } \\
\text { negative by } \\
\text { EIA }\end{array}$ & $\begin{array}{c}\text { No. of sera } \\
\text { positive by } \\
\text { EIA }\end{array}$ \\
\hline Early Lyme borreliosis & 14 & 14 \\
$\quad$ EM & 1 & 2 \\
EM, culture positive & & 29 \\
Late Lyme borreliosis & 6 & 7 \\
Arthritis & 2 & 3 \\
Arthralgia & 1 & 3 \\
ACA & & 9 \\
Patient control & 18 & 0 \\
RA & 9 & 0 \\
Ankylosing spondylitis & 9 & 0 \\
Psoriatic arthritis & 4 & 1 \\
Reactive arthritis & 5 & 12 \\
SLE & 8 & 31 \\
Arthritis e.c.i. & 8 & \\
Syphilis & 13 & \\
Healthy control & & \\
\hline
\end{tabular}

EIA. Enzyme immunoassay.

EM. Erythema migrans.

ACA. Acrodermatitis chronica atrophicans. RA. Rheumatoid arthritis.

SLE. Systemic lupus erythematosus.

\section{Sodium dodecyl-sulphate Polyacrylamide Gel Electrophoresis}

The whole-cell sonicate used was obtained from B. burgdorferi B31 (ATCC 35210). Procedures for antigen preparation were described before (17). The protein concentration of the antigen was determined by the Bio-Rad protein assay (Bio-Rad Laboratories, Germany). Sodium dodecyl-sulphate (SDS)-polyacrylamide gel electrophoresis (PAGE) was performed essentially as described by Laemmli (34). Twenty five $\mu \mathrm{g}$ portions of the spirochetal protein were dissolved in an equal volume of sample buffer $(0.5 \mathrm{M} \mathrm{Tris-HCl}$ [pH 6.8], $10 \%$ glycerol, $2 \%$ SDS, $5 \%$ B-mercaptoethanol, $0.001 \%$ bromophenol blue), heated for $5 \mathrm{~min}$. at $95^{\circ} \mathrm{C}$ and electrophoresed on a $0.5 \mathrm{~mm}$ gel $(11 \%$ acrylamide, $0.33 \%$ bisacrylamide, $0.1 \%$ SDS, $1.5 \mathrm{M}$ Tris- $\mathrm{HCl}$ [pH6.8]). The stacking gel contained $4 \%$ acrylamide, $0.33 \%$ bisacrylamide, $0.1 \% \mathrm{SDS}$ and $0.5 \mathrm{M}$ Tris- $\mathrm{HCl}$ [pH6.8]. Electrophoresis was performed in a Protean II Slab Cell (Bio-Rad Laboratories, USA). Low molecular mass $\left(\mathrm{M}_{r}\right)$ standards (LMW Calibration Kit, Pharmacia, Sweden) were included in each gel. 


\section{Western Immunoblot}

The spirochetal proteins separated by SDS-PAGE were transferred from the gel to a $0.2 \mu \mathrm{m}$-pore-size nitrocellulose membrane (BA83, Schleicher and Schüll, Germany) in a Multiphor II Novablot (Pharmacia) using a transfer buffer containing $0.05 \mathrm{M}$ Tris- $\mathrm{HCl}, 0.04 \mathrm{M}$ glycine, $0.0375 \%$ SDS and $20 \%$ ( $\mathrm{vol} / \mathrm{vol}$ ) methanol. Transfer was carried out at $0.8 \mathrm{~mA} / \mathrm{cm}^{2}$ of the transunit for $1 \mathrm{~h}$. The blots were blocked overnight with $1 \%$ bovine serum albumin (fraction V, Boehringer, Germany) in PBS, rinsed in PBS with the addition of $0.5 \%$ Tween 20 (PBS-T) and subsequently incubated in PBS-T for $30 \mathrm{~min}$. Immunoblotting was performed by means of a Miniblotter 25 (Immunetics, USA) according to the step-by-step technical instructions of the manufacturer. The membranes were incubated with a 1:100 dilution of each serum in PBS containing $5 \mathrm{mM} \mathrm{MgCl}$ (PBS- $\mathrm{MgCl}_{2}$ ), at room temperature for $1 \mathrm{~h}$. To ensure reproducibility of the assay a negative control serum showing no bands, a positive control serum with a broad reactivity pattern as well as the following mouse monoclonal antibodies directed against $B$. burgdorferi (Symbicom, Sweden) were included on each membrane: H9724 to the $41 \mathrm{kDa}$ flagella antigen (35), $\mathrm{H} 5332$ to the $31 \mathrm{kDa}$ OspA protein (36) and $\mathrm{H} 6831$ to the $34 \mathrm{kDa}$ OspB protein (37). After washing three times with PBS-T, the blots were incubated at room temperature for $1 \mathrm{~h}$ either with alkaline phosphatase-conjugated anti-human IgG (A5403, Sigma, USA) or with alkaline phosphatase-conjugated anti-mouse IgG (A1902, Sigma) diluted 1:600 in PBS-T. The blots were washed twice with PBS-T, incubated with Tris- $\mathrm{MgCl}_{2}\left(0.1 \mathrm{M}\right.$ Tris- $\left.\mathrm{HCl}, 0.1 \mathrm{M} \mathrm{NaCl}, 0.05 \mathrm{M} \mathrm{MgCl}_{2}[\mathrm{pH} 9.5]\right)$ for 5 $\mathrm{min}$. and transferred to a substrate solution containing $165 \mu \mathrm{g} / \mathrm{ml} 5$-bromo4-chloro-3-indolyl phosphate (B8503 Sigma) (stock solution, $50 \mathrm{mg} / \mathrm{ml}$ in dimethylformamide) and $330 \mu \mathrm{g} / \mathrm{ml}$ nitro blue tetrazolium (N6876 Sigma) (stock solution, $75 \mathrm{mg} / \mathrm{ml}$ in $70 \%$ dimethylformamide) in Tris- $\mathrm{MgCl}_{2}$. After 4 min. incubation in the dark, the enzymatic reaction was stopped by rinsing the blots in Tris-EDTA (0.02 M Tris-HCl, $0.0005 \mathrm{M} \mathrm{Na}_{2}$ EDTA [pH 7.5]). Absolute running distances of bands were determined in $\mathrm{mm}$ and band intensities were scored on an ordinal scale as 3 (strong), 2 (distinct), or 1 (weak).

\section{Statistical Analysis}

$\mathrm{kDa}$ values of protein bands were calculated from their corresponding standard curves using logarithmic regression analysis. Because the distribution of bands produced by the 209 sera analysed showed that nearly every $\mathrm{kDa}$ value between $5 \mathrm{kDa}$ and $98 \mathrm{kDa}$ occurred, further analysis was performed using fourteen ranges rather than individual $k D a$ values (Figure 1). These $\mathrm{kDa}$ ranges were defined on the basis of peaks in the frequency chart in combination with findings by others regarding regularly occurring bands in sera from patients with Lyme borreliosis $(26,27,30)$. $\mathrm{kDa}$ ranges comprising at least one (weak) band were considered positive and $\mathrm{kDa}$ ranges comprising no band were considered negative. $\chi^{2}$-tests were used to determine the associations between the $\mathrm{kDa}$ ranges ( $\mathrm{kDa}$ range positive/ $\mathrm{kDa}$ range negative) and the clinical diagnosis (Lyme borreliosis/no Lyme borreliosis). 


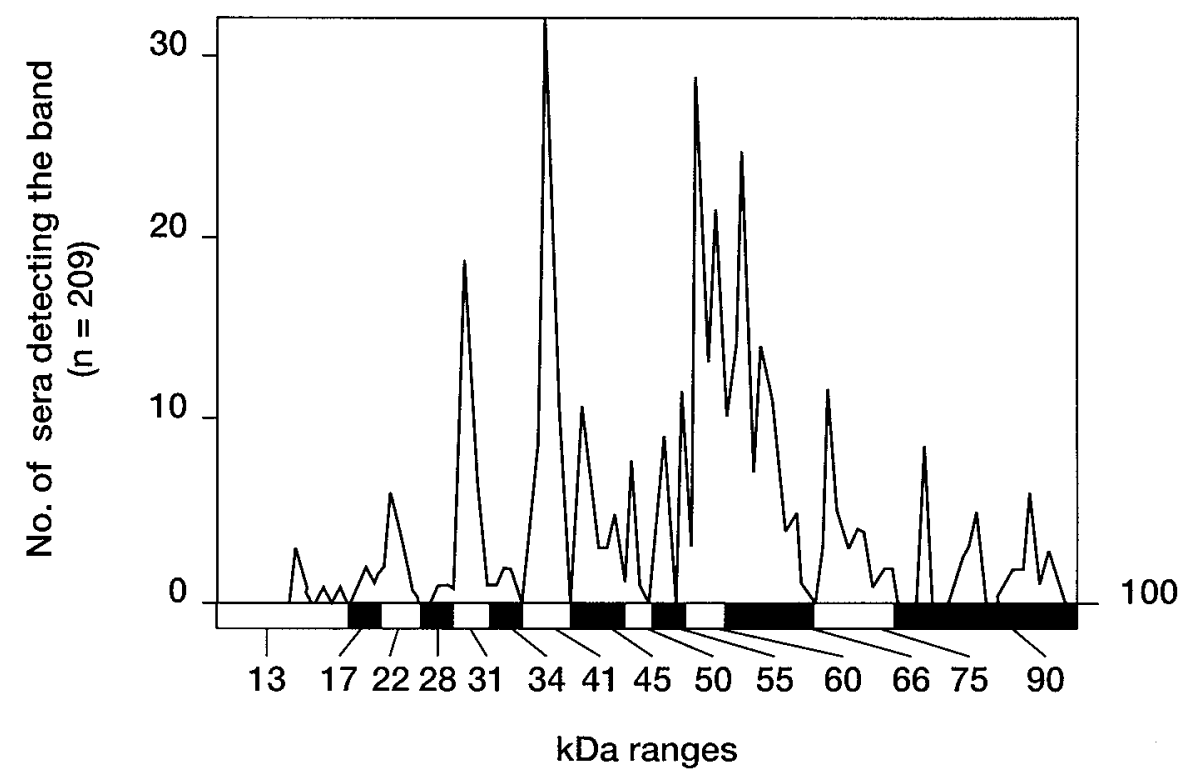

Figure 1. Distribution of protein bands produced by 209 sera used for evaluation of Western immunoblot. Based on this frequency chart the following $14 \mathrm{kDa}$ ranges were defined: $\leq 15 \mathrm{kDa}$ (13 kDa range); $16-19 \mathrm{kDa}$ (17 kDa range); $20-25 \mathrm{kDa}(22$ $\mathrm{kDa}$ range); $26-29 \mathrm{kDa}$ (28 kDa range); $30-33 \mathrm{kDa}$ (31 kDa range); $34-37 \mathrm{kDa}$ (34 $\mathrm{kDa}$ range); $38-42 \mathrm{kDa}$ (41 kDa range); $43-48 \mathrm{kDa}$ (45 kDa range); $49-52 \mathrm{kDa}(50$ $\mathrm{kDa}$ range); $53-57 \mathrm{kDa}$ (55 kDa range); $58-61 \mathrm{kDa}$ (60 kDa range); 62-69 kDa (66 $\mathrm{kDa}$ range); $70-79 \mathrm{kDa}$ (75 kDa range); 80-100 kDa (90 kDa range).

The predictive value of the Western immunoblot was evaluated by means of logistic regression, with $\mathrm{kDa}$ ranges as independent variables. Different equations (models) were estimated to assess the best predictive model. A Western blot result was considered positive if the chance of Lyme borreliosis was $\geq 50 \%$.

\section{RESULTS}

\section{Occurrence of Positive kDa Ranges in Relation to Study Groups}

Table 2 presents the distribution of positive $\mathrm{kDa}$ ranges among the four study groups, when all bands regardless of their intensities were taken into account. $\mathrm{kDa}$ ranges which were positive in early or late Lyme borreliosis also occurred fairly frequently in patient controls healthy individuals. Of the 209 sera analysed $3 / 48$ sera from patients with late Lyme borreliosis, 10/86 sera in the patient control group and $7 / 44$ healthy controls did not produce antibodies. In early and late Lyme borreliosis the mean numbers of bands 
were 5 (minimum 2, maximum 11) and 7 (minimum 0 , maximum 14), respectively. The mean numbers of bands in the patient control and the healthy control groups were 4 (minimum 0 , maximum 14) and 3 (minimum 0 , maximum 9), respectively. In patients with Lyme borreliosis the mean number of bands was significantly higher than in the controls $(p<0.05)$. Considering only the region below the $41 \mathrm{kDa}$ range, patients with Lyme borreliosis produced antibodies to one or more proteins significantly more often as compared to the controls $(53 / 79$ versus $31 / 130 ; p<0.05)$. Antibodies to the proteins in the $31 \mathrm{kDa}$ range were most often found, regardless of the study group considered. Antibodies to proteins in the $22 \mathrm{kDa}$ range were more often detected in patients with late Lyme borreliosis as compared to the remaining three study groups. Considering only the ranges of $41 \mathrm{kDa}$ to $90 \mathrm{kDa}$, no differences were observed in the numbers of sera per study group producing antibodies to any particular protein. In all four study groups antibodies to proteins in the $66 \mathrm{kDa}$ range were most often found, followed by antibodies to proteins in the $41 \mathrm{kDa}$ range and the $60 \mathrm{kDa}$ range. Patients with early Lyme borreliosis, patient controls and healthy controls had antibodies to one or more proteins in the range of $41 \mathrm{kDa}$ to $90 \mathrm{kDa}$ significantly more often than antibodies against proteins with lower molecular masses $(p<005)$. Table 3 compares the percentages of positive $k D a$ ranges in Lyme borreliosis and control sera for all bands and for distinct and strong bands only. Considering all bands, regardless of their intensities, significant differences between Lyme borreliosis and controls were seen in the 17, 22, 28, 31, $34,45,50,55$, and $90 \mathrm{kDa}$ ranges. Among distinct and strong bands, only the $22,31,41,45,55,60,66$, and $90 \mathrm{kDa}$ ranges were positive in Lyme borreliosis significantly more often than in controls. In the $13,31,41,45,55$, 60,66 and $90 \mathrm{kDa}$ ranges more than $35 \%$ of the bands were distinct or strong (Table 2).

\section{Validity of Western Immunoblot}

The validity of Western immunoblot band patterns in the serodiagnosis of Lyme borreliosis was evaluated at the level of a specific diagnostic laboratory test, for which both the predictive value of a positive test result and that of a negative result should be high. Therefore, several logistic regression models i.e. several combinations of $\mathrm{kDa}$ ranges and study groups were compared. The best results were obtained with the following models in which "Lyme borreliosis" was compared with "non-Lyme borreliosis": 1) all fourteen $\mathrm{kDa}$ ranges (Figure 1), 2) only the $\mathrm{kDa}$ ranges which were significantly more often positive in patients with Lyme borreliosis than in controls (Table 3 ), and 3 ) only the $\mathrm{kDa}$ ranges which were estimated to be less sensitive to idiosyncrasies (Table 2) and 4) all three models with regard to all bands as well as distinct and strong bands only. With these six models the percentages of correct predicted cases of Lyme borreliosis and controls ranged from $61 \%$ to $65 \%$ and from $88 \%$ to $90 \%$, respectively. Table 4 compares the Western immunoblot results obtained with the model based on all fourteen $\mathrm{kDa}$ ranges with regard to distinct and strong bands only, with those obtained previously with the in-house EIA. 


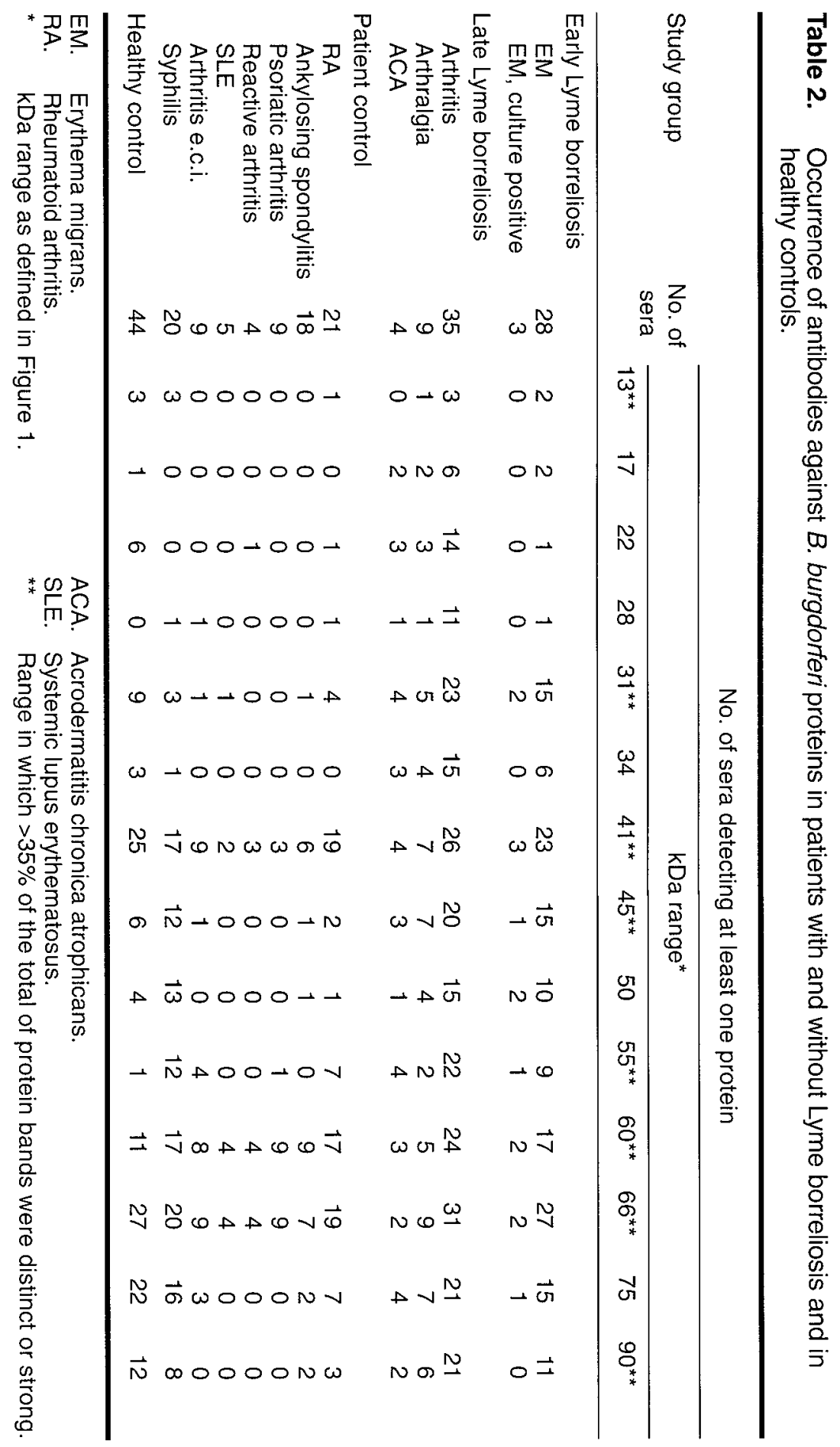


In early as well as late Lyme borreliosis the sensitivity of Western immunoblot (52\% and $71 \%$, respectively) was comparable to that of EIA (52\% and $81 \%$, respectively). In the patient control and the healthy control groups Western immunoblot was more specific ( $87 \%$ and $95 \%$, respectively) than EIA $(71 \%$ and $30 \%$, respectively) $(p<0,05)$. False positive EIA results in ankylosing spondylitis and syphilitic sera could be reduced from $9 / 18$ to $0 /$ 18 and from 12/20 to 5/20. False positive results in RF positive sera were more often seen in Western immunoblot than in EIA.

\section{DISCUSSION}

The problems encountered in interpreting EIA results are causing laboratories increasingly to be confronted with demands to confirm the clinical suspicion of Lyme borreliosis by means of Western immunoblot. In this study whole-cell sonicate Western immunoblot was significantly more specific than EIA $(90 \%$ versus $57 \%)$ in accordance with the results by others $(24,26,28,29)$. However, it cannot be concluded from these data that Western immunoblot is a specific confirmatory test for Lyme borreliosis. First, Western immunoblot could only reduce false positive EIA results in the patient control group by $50 \%$. Second, the correlation coefficient between EIA and immunoblot results in patients with Lyme borreliosis was only $0.41(p<0.05)$. Third, Western immunoblot results were compared with those obtained with a wholecell sonicate EIA. In a previous study this EIA was compared with three ElAs based on purified flagella or flagellin enriched antigens (17). These latter three assays were all significantly more specific in patient controls than the whole-cell sonicate EIA ( $\geq 97 \%$ versus $29 \%$ ). Although Western immunoblotting is a well established specific confirmatory test for the detection of human immunodeficiency virus (HIV) infection, diagnosing Lyme borreliosis is totally different since the immune response is directed against a broad array of $B$. burgdorferi proteins several of which are cross-reactive $(18-20,24,30,38,39)$. The pattern of response depends on the stage of the illness and, even among patients in the same stage, the immune response is highly variable. Besides the technical obstacles inherent in the performance of Western immunoblot, which may be overcome partly by the use of commercial available kits, the lack of standardization and the subjectivity in interpretation present two further problems. Central to the issue of standardization are the criteria for positivity. In this study, we used several regression models in which either the number, intensity, or type of bands, was employed. However, no support was found for using specific criteria. Problems, which are encountered with all serological methods for Lyme borreliosis including Western immunoblot, are raised by the question which $B$. burgdorferistrain(s) and antigen preparation ideally should be used. $B$. burgdorferi sensu lato comprises at least three genomic species which differ in the type and amount of outer membrane proteins expressed and therefore may elicit different antibody responses (40-43). Hence, a patient's serum 
Table 3. Comparison of positive $\mathrm{kDa}$ ranges in sera from patients with and without Lyme borreliosis and in healthy controls.

\begin{tabular}{|c|c|c|c|c|}
\hline \multirow{3}{*}{ kDa range* } & \multicolumn{4}{|c|}{ Sera detecting at least one protein $(\%)$} \\
\hline & \multicolumn{2}{|c|}{ All band intensities } & \multicolumn{2}{|c|}{ Distinct and strong bands only } \\
\hline & $\begin{array}{c}\text { Lyme } \\
\text { borreliosis } \\
n=79\end{array}$ & $\begin{array}{l}\text { Controls } \\
n=130\end{array}$ & $\begin{array}{c}\text { Lyme } \\
\text { borreliosis } \\
n=79\end{array}$ & $\begin{array}{l}\text { Controls } \\
n=130\end{array}$ \\
\hline 13 & 8 & 5 & 4 & 2 \\
\hline 17 & $15^{\star \star}$ & 1 & 3 & 1 \\
\hline 22 & $27^{\star \star}$ & 6 & $11^{\star *}$ & - \\
\hline 28 & $18^{\star \star}$ & 2 & 4 & - \\
\hline 31 & $62^{\star \star}$ & 15 & $29^{\star \star}$ & 3 \\
\hline 34 & $35^{* *}$ & 3 & 8 & - \\
\hline 41 & 80 & 65 & $49^{* *}$ & 13 \\
\hline 45 & $58^{* *}$ & 17 & $27^{\star \star}$ & 2 \\
\hline 50 & $41^{* *}$ & 15 & 4 & 5 \\
\hline 55 & $48^{* *}$ & 19 & $25^{\star}$ & 3 \\
\hline 60 & 65 & 61 & $48^{* *}$ & 15 \\
\hline 66 & 90 & 76 & $49^{\star \star}$ & 19 \\
\hline 75 & 61 & 39 & 23 & 9 \\
\hline 90 & $51^{* *}$ & 19 & $27^{\star \star}$ & 7 \\
\hline
\end{tabular}

* kDa range as defined in Figure 1.

** Differences between Lyme borreliosis and controls were significant $(p<0.05)$.

may exhibit different immunoblot band patterns when tested with different $B$. burgdorferi strains.

It has been suggested that the sensitivity and specificity of Western immunoblot may be increased by using purified antigens rather than whole-cell sonicates (44). Wilske et al. (44) studied separately several recombinant proteins including the chromosomal-encoded B. burgdorferi protein $\mathrm{p} 100$, the flagellin and an internal flagellin fragment thereof, and the plasmid-encoded OspA and OspC and found these proteins to be highly specific. However, none of these recombinant blots exceeded the sensitivity of EIA and can not be considered confirmatory tests for Lyme borreliosis because true cases of Lyme borreliosis may be missed. Other problems encountered with the lack of standardization are the use of different concentrations of antigen, different dilutions of serum and reagents and different incubation times. A problem not often mentioned concerns the question of how the 
Table 4. Comparison of Western immunoblot and EIA results in patients with and without Lyme borreliosis and in healthy controls.

\begin{tabular}{|c|c|c|c|}
\hline \multirow{2}{*}{ Study group } & \multirow{2}{*}{$\begin{array}{l}\text { No. of sera } \\
\text { analyzed }\end{array}$} & \multicolumn{2}{|c|}{ No. of sera positive } \\
\hline & & Western blot & EIA \\
\hline EM & 28 & 13 & 14 \\
\hline EM, culture positive & 3 & 3 & 2 \\
\hline Total early LB & 31 & $16(52 \%)$ & $16(52 \%)$ \\
\hline Arthritis & 35 & 24 & 29 \\
\hline Arthralgia & 9 & 6 & 7 \\
\hline ACA & 4 & 4 & 3 \\
\hline Total late LB & 48 & $34(71 \%)$ & $39(81 \%)$ \\
\hline RA & 21 & 6 & 3 \\
\hline Ankylosing spondylitis & 18 & - & 9 \\
\hline Psoriatic arthritis & 9 & - & - \\
\hline Reactive arthritis & 4 & - & - \\
\hline SLE & 5 & - & - \\
\hline Arthritis e.c.i. & 9 & - & 1 \\
\hline Syphilis & 20 & 5 & 12 \\
\hline Total patient control ${ }^{*}$ & 86 & $11(13 \%)$ & $25(29 \%)$ \\
\hline Total healthy control $^{*}$ & 44 & $2(5 \%)$ & $31(70 \%)$ \\
\hline
\end{tabular}

EIA. Enzyme immunoassay.

ACA. Acrodermatitis chronica atrophicans.

SLE. Systemic lupus erythematosus.
EM. Erythema migrans.

RA. Rheumatoid arthritis.

* Differences between Western immunoblot and EIA were significant $(p<0.05)$.

accuracy of band location is to be standardized. In the present study, this problem was solved, at least in part, by using $\mathrm{kDa}$ ranges rather than individual $\mathrm{kDa}$ values.

Our finding that antibodies to proteins in the $41 \mathrm{kDa}$ range and the $60-75$ $\mathrm{kDa}$ heat-shock proteins did not discriminate between patients with Lyme borreliosis and controls is in accordance with the findings by others $(18,24,30)$. Bruckbauer et al. (39) demonstrated broad cross-reactivity of $B$. burgdorferi with bacteria belonging to the endogenous flora.

It has been postulated that the $22 \mathrm{kDa} O \mathrm{spC}$ is a major immunodominant protein in early Lyme borreliosis (45). However, in the present study, antibodies to the proteins in the $22 \mathrm{kDa}$ range were significantly more often found in late Lyme borreliosis than in early disease. This finding may be explained by the observations of Wilske et al. (45) that proteins may occur in the 20-25 kDa region which are not surface-associated. A 22-25 kDa 
band may falsely be interpreted as an OspC band especially in late Lyme borreliosis in which antibodies are produced against a broad range of borrelial proteins. This explanation is also supported by the fact that our wholecell sonicate was prepared from $B$. burgdorferi B31, a strain which is known not to express OspC (45).

In conclusion, this study indicates that the results of Western immunoblot for Lyme borreliosis are not significantly affected by different criteria used for positivity. In accordance with the literature, Western immunoblot was found significantly more specific than EIA. However, the use of immunoblot as a confirmatory or alternative test to a good EIA should be viewed with caution, since immunoblot does not solve all the problems of interpretation that confront the clinician. 


\section{REFERENCES.}

1. Steere AC. Lyme disease. New England Journal of Medicine 1989; 321: 586596.

2. Rahn DW. Lyme disease: clinical manifestations, diagnosis, and treatment. Seminars in Arthritis and Rheumatism 1991; 20: 201-218.

3. Steere AC, Grodzicki RL, Kornblatt AN, Craft JE, Barbour AG, Burgdorfer W, Schmid GP, Johnson E, Malawista SE. The spirochetal etiology of Lyme disease. New England Journal of Medicine 1983; 308: 733-740.

4. Haupl T, Burmester GR. Klinik, Diagnostik und Therapie der Lyme-Borreliose. Zeitschrift für Ärztliche Fortbildung 1992; 86: 6-12.

5. Nadelman RB, Pavia CS, Magnarelli LA, Wormser GP. Isolation of Borrelia burgdorferi from the blood of seven patients with Lyme disease. American Journal of Medicine 1990; 88: 21-26.

6. de Koning J, Bosma RB, Hoogkamp-Korstanje JAA. Demonstration of spirochaetes in patients with Lyme disease with a modified silver stain. Journal of Medical Microbiology 1987; 23: 261-267.

7. Valesova M, Trnavsky K, Hulinska D, Alusik S, Janousek J, Jirous J. Detection of Borrelia in the synovial tissue from a patient with Lyme borreliosis by electron microscopy. Journal of Rheumatology 1989; 16: 1502-1505.

8. Banyas GT. Difficulties with Lyme serology. Journal of the American Optometric Association 1992; 63: 135-139.

9. Dattwyler RJ, Volkman DJ, Luft BJ, Halperin JJ, Thomas J, Golightly MG. Seronegative Lyme disease. Dissociation of specific T- and B-lymphocyte responses to Borrelia burgdorferi. New England Journal of Medicine 1988; 319: 1441-1446.

10. Hyde FW, Johnson RC, White TJ, Shelburne CE. Detection of antigens in urine of mice and humans infected with Borrelia burgdorferi, etiologic agent of Lyme disease. Journal of Clinical Microbiology 1989; 27: 58-61.

11. Melchers W, Meis J, Rosa P, Claas E, Nohlmans L, Koopman R, Horrevorts A, Galama J. Amplification of Borrelia burgdorferi DNA in skin biopsies from patients with Lyme disease. Journal of Clinical Microbiology 1991; 29: 24012406.

12. Craft JE, Grodzicki RL, Steere AC. Antibody response in Lyme disease: evaluation of diagnostic tests. Journal of Infectious Diseases 1984; 149: 789-795.

13. Cutler SJ, Wright DJM. Evaluation of three commercial tests for Lyme disease. Diagnostic Microbiology and Infectious Diseases 1990; 13: 271-272.

14. Stiernstedt G, Eriksson G, Enfors W, Jorbeck $H$, Svenungsson B, Skoldenberg $B$, Granstrom M. Erythema chronicum migrans in Sweden: clinical manifestations and antibodies to /xodes ricinus spirochete measured by indirect immunofluorescence and enzyme-linked immunosorbent assay. Scandinavian Journal of Infectious Diseases 1986; 18: 217-224.

15. Russell H, Sampson JS, Schmid GP, Wilkinson HW, Plikaytis B. Enzyme-linked immunosorbent assay and indirect immunofluorescence assay for Lyme disease. Journal of Infectious Diseases 1984; 149: 465-470. 
16. Asbrink E, HovmarkA; Hederstedt $B$. Serological studies of erythema migrans Afzelius and acrodermatitis chronica atrophicans with indirect immunofluorescence and enzyme-linked immunosorbent assays. Acta Dermato-Venereologica 1985; 65: 509-514.

17. Nohlmans MKE, BlaauwAAM, van den BogaardAEJM, van Boven CPA. Evaluation of nine serological tests for diagnosis of Lyme borreliosis. European Journal of Clinical Microbiology and Infectious Diseases 1994; 13: 394-400.

18. Hansen K, Bangsborg JM, Fjordvang H, Strandberg-Pedersen N, Hindersson P. Immunochemical characterization and isolation of the gene for a Borrelia burgdorferi immunodominant 60-kilo-dalton antigen common to a wide range of bacteria. Infection and Immunity 1988; 56: 2047-2053.

19. Magnarelli LA, Miller JM, Anderson JF, Riviere GF. Cross-reactivity of nonspecific treponemal antibody in serologic tests for Lyme disease. Journal of Clinical Microbiology 1990; 28: 1276-1279.

20. Coleman JL, Benach JL. Characterization of antigenic determinants of Borrelia burgdorferi shared by other bacteria. Journal of Infectious Diseases 1992; 165: 658-666.

21. Fawcett PT, Gibney KM, Rose CD, Klein JD, Doughty RA. Adsorption with a soluble $E$. coliantigen fraction improves the specificity of ELISA tests for Lyme disease. Journal of Rheumatology 1991; 18: 705-708.

22. Stiernstedt G, Dattwyler R, Duray PH, Hansen $K$, Jirous J, Johnson RC, Karlsson $M$, Preac-Mursic V, Schwan TG. Diagnostic tests in Lyme borreliosis. Scandinavian Journal of Infectious Diseases, Supplement 1991; 77: 136142.

23. Grodzicki RL, Steere AC. Comparison of immunoblotting and indirect enzymelinked immunosorbent assay using different antigen preparations for diagnosing early Lyme disease. Journal of Infectious Diseases 1988; 157: 790-797.

24. Zöller L, Burkard S, Schäfer H. Validity of Western immunoblot band patterns in the serodiagnosis of Lyme borreliosis. Journal of Clinical Microbiology 1991; 29: 174-182.

25. Karlsson M, Möllegard I, Stiernstedt G, Wretlind B. Comparison of Western blot and enzyme-linked immunosorbent assay for diagnosis of Lyme borreliosis. European Journal of Clinical Microbiology and Infectious Diseases 1989; 8: 871-877.

26. Zöller L, Cremer J, Faulde M. Western blot as a tool in the diagnosis of Lyme borreliosis. Electrophoresis 1993; 14: 937-944.

27. Bingnan MA, Christen B, Leung D, Vigo-Pelfrey C. Serodiagnosis of Lyme borreliosis by western immunoblot: reactivity of various significant antibodies against Borrelia burgdorferi. Journal of Clinical Microbiology 1992; 30: 370376.

28. Rose CD, Fawcett PT, Singsen BH, Dubbs SB, Doughty RA. Use of Western blot and enzyme-linked immunosorbent assays to assist in the diagnosis of Lyme disease. Pediatrics 1991; 88: 465-470.

29. Dressler F, Whalen JA, Reinhardt BN, SteereAC. Western blotting in the serodiagnosis of Lyme disease. Journal of Infectious Diseases 1993; 167: 392400.

30. Golightly MG, Thomas JA, Viciana AL. The laboratory diagnosis of Lyme borreliosis. Laboratory Medicine 1990; 21: 299-304. 
31. Nohlmans MKE, van den Bogaard AEJM, Blaauw AAM, van Boven CPA. Prevalentie van Lyme borreliose in Nederland. Nederlands Tijdschrift voor Geneeskunde 1991; 135: 2288-2292.

32. Blaauw AAM, Nohlmans MKE, Leffers $P$, Goei The $H$, van der Linden Sj. Lyme borreliosis: a very infrequent cause of arthritis of undetermined aetiology in the southern part of the Netherlands. British Journal of Rheumatology 1992; 31: 401-404.

33. Case definition for public health surveillance. Medical Microbiology Weekly Reports 1990; 39 (RR-13): 19-21.

34. Laemmli UK. Cleavage of structural proteins during the assembly of the head of bacteriophage T4. Nature 1970; 227: 680-685.

35. Barbour AG, Hayes SF, Heiland RA, Schrumpf ME, Tessier SL. Borrelia-specific monoclonal antibody binds to a flagella epitope. Infection and Immunity 1986; 52: 549-554.

36. Barbour AG, Tessier SL, Todd WJ. Lyme disease spirochetes and ixodid tick spirochetes share a common surface antigenic determinant defined by a monoclonal antibody. Infection and Immunity 1983; 41: 795-804.

37. BarbourAG, Tessier SL, Hayes SF. Variation in major surface proteins of Lyme disease spirochetes. Infection and Immunity 1984; 45: 94-100.

38. Fawcett PT, Gibney KM, Rose CD, Dubbs SB, Doughty RA. Frequency and specificity of antibodies that cross-react with Borrelia burgdorferi antigens. Journal of Rheumatology 1992; 19: 582-587.

39. Bruckbauer HR, Preac-Mursic V, Fuchs R, Wilske B. Cross-reactive proteins of Borrelia burgdorferi. European Journal of Clinical Microbiology and Infectious Diseases 1992; 11: 224-232.

40. Assous MV, Postic D, Paul G, Nevot P, Baranton G. Western blot analysis of sera from Lyme borreliosis patients according to the genomic species of the Borrelia strains used as antigens. European Journal of Clinical Microbiology and Infectious Diseases 1993; 12: 261-268.

41. Wilske B, Preac-Mursic V, Schierz G, Busch KV. Immunochemical and immunological analysis of European Borrelia burgdorferi strains. Zentralblatt für Bakteriologie, Mikrobiologie und Hygiene [A] 1986; 263: 92-102.

42. Peter O, Bretz AG. Polymorphism of outer surface proteins of Borrelia burgdorferi as a tool voor classification. Zentralblatt für Bakteriologie 1992; 277: 28-33.

43. Wilske B, Preac-Mursic V, Schierz G, Kühbeck R, Barbour AG, Kramer M. Antigenic variability of Borrelia burgdorferi. Annals of the New York Academy of Sciences 1988; 539: 126-143.

44. Wilske B, Fingerle V, Herzer P, Hofmann A, Lehnert G, Peters H, Pfister HW, Preac-Mursic V, Soutschek $E$, Weber $K$. Recombinant immunoblot in the serodiagnosis of Lyme borreliosis. Medical Microbiology and Immunology 1993; 182: 255-270.

45. Wilske B, Preac-Mursic V, Jauris S, HofmannA, Pradel I, Soutschek E, Schwab E, Will G, Wanner G. Immunological and molecular polymorphisms of OspC, an immunodominant major outer surface protein of Borrelia burgdorferi. Infection and Immunity 1993; 61: 2182-2191. 
122 


\section{PREVALENCE OF LYME BORRELIOSIS IN THE NETHERLANDS}

MKE Nohlmans ${ }^{1}$, AEJM van den Bogaard', AAM Blaauw², CPA van Boven ${ }^{1}$

Department of Medical Microbiology, State University of Limburg, Maastricht;

2 Department of Internal Medicine, Division of Rheumatology, University Hospital Maastricht, Maastricht, The Netherlands. 


\section{PREVALENCE OF LYME BORRELIOSIS IN THE NETHERLANDS}

\section{ABSTRACT}

In the autumn of 1989, a sero-epidemiological study was carried out among 440 owners of hunting dogs and 1052 blood donors from different regions in The Netherlands. To detect IgG antibodies to Borrelia burgdorferi an enzyme immunoassay was performed. The prevalence of antibodies to Borrelia burgdorferi in owners of hunting dogs was $15 \%$, which was significantly higher than in blood donors $(9 \%)$. In both groups the prevalence of seropositivity increased with age. There was no difference between men and women. The prevalence of antibodies to Borrelia burgdorferi in blood donors from different regions varied significantly, ranging from $2 \%$ to $17 \%$. Only $3 \%$ of the owners of hunting dogs could recall having had symptoms most likely to be due to Lyme borreliosis. Of the 68 seropositive hunters 64 $(94 \%)$ were asymptomatic. The results of this study indicate that in The Netherlands asymptomatic infections with Borrelia burgdorferi are common in individuals highly exposed to ticks and that there is considerable variation in the prevalence of seropositivity in the general population. Hence caution is called for in the clinical interpretation of IgG test results.

\section{INTRODUCTION}

In recent years there have been regular reports in The Netherlands of Lyme borreliosis, an infectious disease caused by the spirochete Borrelia burgdorferi which, in Europe, is transmitted by the bite of the sheep tick, Ixodes ricinus (1-10). The symptomatology and clinical course of the disease have already been extensively discussed elsewhere (11). Erythema migrans (EM), is a pathognomonic skin lesion arising at the site of the tick bite, but is seen only in about $50 \%$ of clinical cases (12). This, coupled with the generalized character of the disease and diversity of symptoms, leads to many doubtful clinical situations in which serology might be helpful.

An infection with $B$. burgdorferi can proceed unnoticed and without symptoms; the antibodies remaining detectable for many years. A positive serological result raises the question as to whether it indicates an actual infection, or whether it is the result of a previous exposure to the spirochete. Research in Europe and the USA has shown that asymptomatic (seropositive) Lyme borreliosis occurs frequently, particularly in individuals exposed to an increased risk of tick bites (13-21). Little is known about the prevalence of $B$. burgdorferi seropositivity in The Netherlands, either amongst those at high risk, or in the general population. 
In this sero-epidemiological investigation, the prevalence of $\lg G$ antibodies to $B$. burgdorferi was established in owners of working gun dogs. These dogs are required to undergo a qualification test, and are therefore intensively trained by their owners in areas which are usually also a favoured environment for $I$. ricinus. One may therefore assume that owners of these dogs come more into contact with ticks than the average member of the population. Blood donors, matched for age, sex and residential area, were used as controls.

\section{PATIENTS AND METHODS}

\section{Serum Samples}

Blood samples were taken from 440 dog owners during the gun dog qualification trials organized by the Royal Dutch Hunting Association in the autumn of 1989. Information about Lyme disease, and the investigation which had already been published in the association's journal "De Jager", was given to the members during the trials. Participants in the investigation were then shown photographs of EM lesions, and asked to fill in a questionnaire. The questionnaire included questions about the frequency of tick bites, and about symptoms which could possibly be attributed to Lyme disease (skin lesions, facial palsy, meningitis, neuritis, arthritis and cardiac symptoms), either at the time of blood sampling or in the past. In general, the dog owners were prepared to take part in the investigation and to give a blood sample after their dogs had completed the trial. The group comprised $35 \%$ of the total number of participants, who were mainly the owners of young dogs which had taken part in the qualification trials in the early afternoon. Donor sera, including date of birth and sex of the donors, was made available by ten Red Cross blood banks. The number of donors (total 1052) was, per category of age (Figure 1) and sex, at least twice that of the gun dog owners, who were matched with each blood bank on the basis of their post code.

\section{Serological Investigation}

The prevalence of $\lg G$ antibodies to $B$. burgdorferi was determined by means of an enzyme immunoassay (E|A) as described by Craft et al. (22). A sonicate of the American type strain B. burgdorferiB31 (ATCC 35210), cultured in Barbour-Kelly-Stoenner-medium (BSKII) (23), was used as antigen. The protein concentration of the sonicate was determined by means of the BioRad protein assay (Bio-Rad Laboratories, Germany). The optimal dilutions of the antigen, conjugate and serum were determined for EIA, by means of positive and negative reference sera, provided by Dr. B. Wilske of the Max von Pettenkofer Institute in Munich, Germany. Microtitre plates were coated with $0.12 \mathrm{mg} / \mathrm{L} \mathrm{B}$. burgdorferi antigen, incubated for one night at $4^{\circ} \mathrm{C}$ and then washed three times with phosphate buffered saline (PBS) containing $0.05 \%$ Tween 20 (PBS-T). After incubation at $37^{\circ} \mathrm{C}$ for one hour with $1: 100$ diluted serum, followed by three washes with PBS-T, the plates were incu- 
Table 1. Prevalence of IgG antibodies to Borrelia burgdorferi in blood donors and owners of gun dogs, per region.

\begin{tabular}{lrrrrrrr}
\hline \multirow{2}{*}{ Region } & \multicolumn{3}{c}{ Owners of gun dogs } & \multicolumn{3}{c}{ Blood donors } \\
\cline { 2 - 7 } & \multicolumn{2}{c}{ Total } & Positive (\%) & & \multicolumn{2}{c}{ Total } & \multicolumn{2}{c}{ Positive (\%) } \\
\hline Groningen & 25 & 4 & $(16)$ & 100 & 2 & $(2)$ \\
Leeuwarden & 30 & 6 & $(20)$ & 105 & 16 & $(15)$ \\
Zwolle & 10 & 1 & $(10)$ & 99 & 8 & $(8)$ \\
Deventer & 19 & 5 & $(26)$ & 72 & 6 & $(8)$ \\
Enschede & 18 & 3 & $(17)$ & 100 & 3 & $(3)$ \\
Arnhem & 24 & 4 & $(17)$ & 106 & 3 & $(3)$ \\
Leiden & 117 & 16 & $(14)$ & 93 & 16 & $(17)$ \\
Hilversum & 49 & 5 & $(10)$ & 91 & 14 & $(15)$ \\
Den Bosch & 99 & 10 & $(10)$ & 134 & 18 & $(13)$ \\
Maastricht & 49 & 14 & $(29)$ & 152 & 5 & $(3)$ \\
\hline Total & 440 & 68 & $(15)$ & 1052 & 91 & $(9)$ \\
\hline
\end{tabular}

bated with alkaline phosphatase-tagged anti-human IgG (A5403, Sigma, USA). The plates were re-washed and after further incubation with paranitrophenyl phosphate, the enzyme reaction was stopped with $5 \mathrm{~N} \mathrm{NaOH}$. The optical density (OD) was measured at $405 \mathrm{~nm}$. The cut-off value (0.35) was determined with reference to the average OD value $(0.15)$ plus twice the standard deviation of the 130 samples of serum from healthy residents of Limburg who had no history of symptoms attributable to Lyme borreliosis; the cut-off value agreed with the 95th percentile value of the optical density of these sera. All tests were conducted in triplicate and three standard samples were included on each plate. Because of the possible crossreaction with syphilis, the positive samples were subjected to screening with the Venereal Disease Research Laboratory (VDRL) and Treponema pallidum haemagglutination assay (TPHA). There were no positive reactions. Differences between percentages were calculated using the $\chi^{2}$ test; $\mathrm{p} \leq 0.05$ was considered significant. 


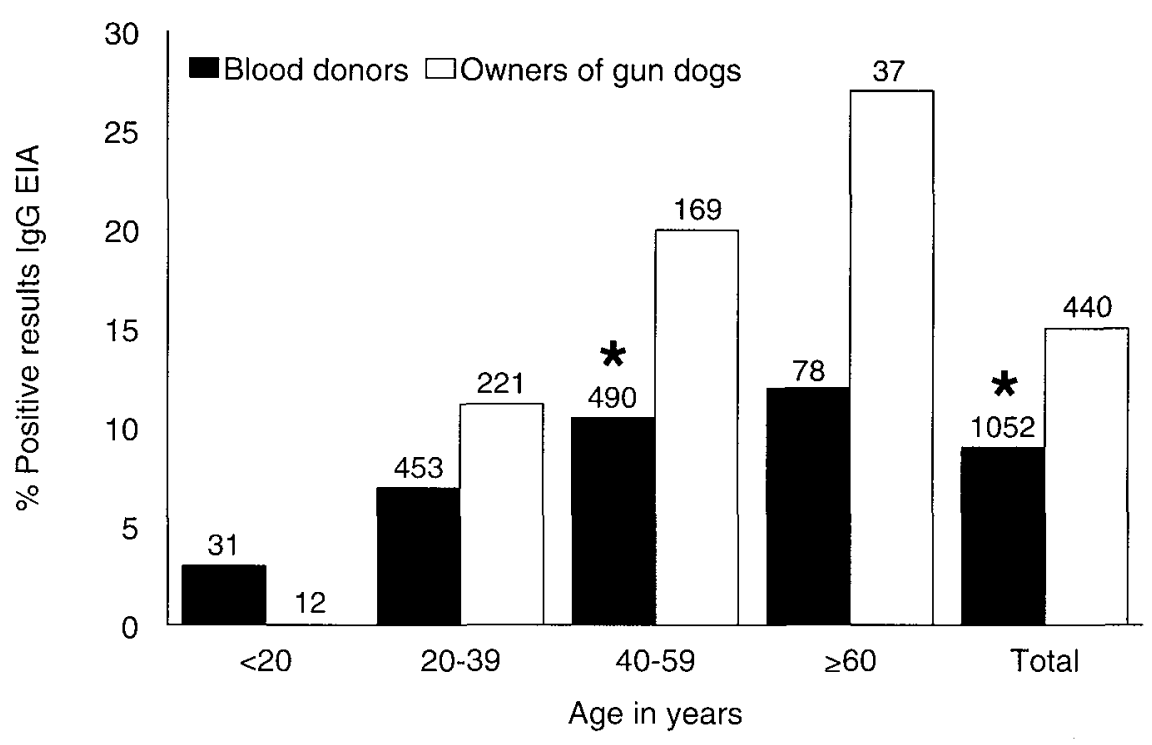

Figure 1. Prevalence of $\lg G$ antibodies to Borrelia burgdorferi in blood donors and owners of gun dogs, according to age. Numbers above the columns designate numbers of subjects in each group. ${ }^{*}$ Differences between donors and owners of gun dogs were significant.

\section{RESULTS}

The prevalence of $B$. burgdorferi antibodies in the 440 gun dog owners (ages varying from 10-76; average 40.5 ; median 42 ) was $15 \%$ ( $95 \%$ confidence interval 13-20). A prevalence of $9 \%$ was found in the 1052 blood donors (95\% confidence interval 8-12; $\mathrm{p}=0.0002$ ) (Table 1).

There were $298(68 \%)$ male dog owners and $142(32 \%)$ female dog owners. The blood donor group comprised 643 (61\%) men, and 409 (39\%) women. Male owners of gun dogs were more often seropositive than male blood donors, $17 \%$ as opposed to $10 \%(p=0.001)$, but the difference between female owners and female blood donors (12\% and $7 \%$ respectively) was not significant. In both groups, dog owners and blood donors, there was no significant sex difference in seropositivity. Seropositivity did however increase in both groups with increasing age: from 3\% (blood donors) and $0 \%$ (dog owners) in the age group $<20$, to $12 \%$ and $27 \%$ respectively in participants older than 59 (Figure 1). There was a significant difference $(p=0.01)$ amongst the dog owners in respect to age groups. Dog owners in 


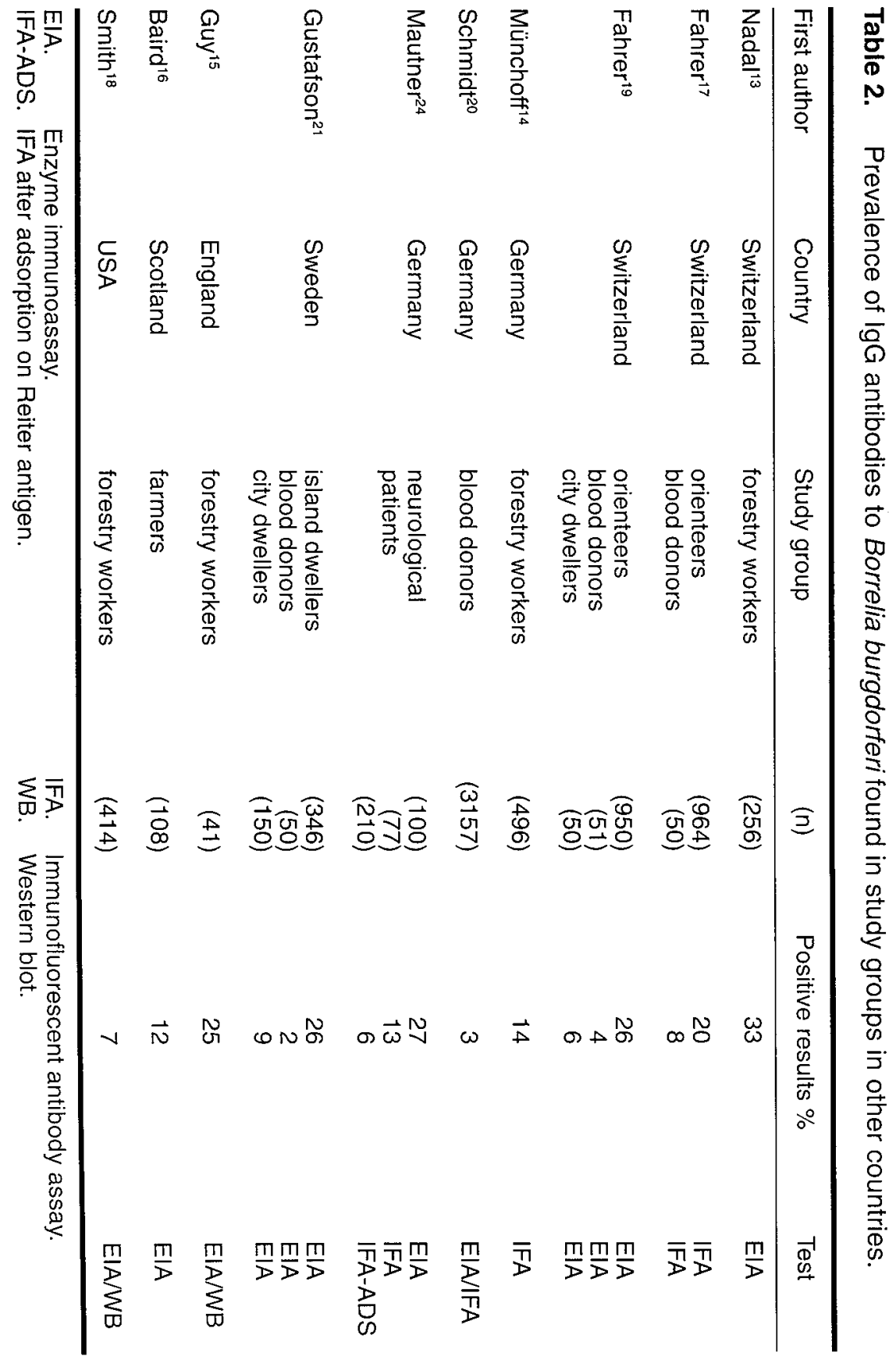


the age group 40-59 were more often seropositive than the same age group of blood donors $(p=0.002)$. The prevalence of antibodies to $B$. burgdorferi in owners of gun dogs varied from $10 \%$ around Den Bosch, Hilversum and Zwolle, to $29 \%$ in the region around Maastricht. Seropositivity in blood donors varied from $2 \%$ in Groningen to $17 \%$ in the area around Leiden (Table 1). In contrast to gun dog owners, significant seropositivity according to region was found in blood donors. There was no correlation between the prevalence of $B$. burgdorferi seropositivity in dog owners and blood donors from the same regions.

In the group of gun dog owners, the relationship between the "test results and tick bites", and "test results and symptoms", was analysed. Of the 68 seropositive participants, $33(49 \%)$ had been bitten at least once by ticks; $130(35 \%)$ of the seronegative participants also confirmed having been bitten by ticks $(p=0.045)$. Fifty-six $(82 \%)$ of the 68 seropositive participants had a clean sheet as regards symptoms, as did $345(93 \%)$ of the 372 seronegative participants. Twenty-five dog owners reported symptoms which could have been due to Lyme borreliosis. These symptoms were: facial palsy $(n=2)$, neuritis $(n=4)$, arthritis $(n=9)$, cardiac symptoms $(n=10)$, and skin lesions $(n=7)$. Of eight seropositive participants in this group, one had had neuritis and three had had attacks of arthritis. Four people admitted to having had cardiac symptoms. Only $14(3 \%)$ of the 440 dog owners recognised the photographs of EM. Of these, four had a positive and ten a negative test result. Two of the seropositive and seven of the seronegative participants who recognised EM, had been treated with antibiotics because of these lesions. The prevalence of asymptomatic (seropositive) Lyme borreliosis, in the dog owners who recognised EM, was $94 \%$.

\section{DISCUSSION}

IgG antibodies to $B$. burgdorferi were detected in $15 \%$ of gun dog owners and $9 \%$ of blood donors. These results are in keeping with reports from elsewhere (Table 2). When comparing the prevalence of $B$. burgdorferi antibodies, it is of primary importance to consider the method used for detection. This is apparent from the Hamburg study, when patients with neurological symptoms were investigated using three different methods (Table 2) (24). Similarly, in an investigation of our own in Maastricht, 128 healthy subjects were investigated for the presence of antibodies to $B$. burgdorferi, and positive results were obtained in $4 \%, 7 \%$ and $2 \%$ using EIA, an immunofluorescent antibody assay (IFA) without adsorption of sera, and an IFA after adsorption of sera on Reiter antigen (IFA-ADS) respectively.

The considerable inter-laboratory variability for identical test methods must also be taken into account (25). Comparing our results for the IgG EIA, with results obtained by the National Institute for Public Health and Environmental Protection (RIVM, Bilthoven, The Netherlands) and a Swiss laboratory (University of Neuchâtel), we found a correlation of 0.94 for one batch of 216 sera $(p<0.0001)$, and 0.68 for a batch of 51 sera $(p=0.0001)$, respectively. 
The percentage of seropositive subjects also increased with age in other studies. Since antibodies to $B$. burgdorferi remain detectable for many years, this increase can be explained by the enhanced chance of infestation with $I$. ricinus and therefore of infection by $B$. burgdorferi, which accompanies increasing age. The fact that $51 \%$ of the gun dog owners who were seropositive could not recall having suffered tick bites, does not exclude a previous exposure to $B$. burgdorferi. It does however show that asking about previous tick bites is of limited help in establishing the diagnosis of Lyme borreliosis. No regional differences in the prevalence of seropositivity amongst gun dog owners was found. A possible explanation could be that the owners, notwithstanding their place of residence, train their dogs and hunt in areas which are in most cases favourable environments, for $I$. ricinus. The prevalence of IgG antibodies to $B$. burgdorferi in blooddonors differed significantly according to region. This is probably a reflection of regional differences in tick population densities, or the different degrees of infection of $l$. ricinus, together with the preference shown by these ticks for particular environments. What is surprising is that, particularly in the western areas of The Netherlands, blood donors were found to be seropositive at least as frequently as gun dog owners. This could be explained by the fact that sand dunes, which are major areas of outdoor recreation in the west, and where often little clothing of a protective kind is worn, have a dense tick population.

Antibodies to $B$. burgdorferi were found in only one in three of the gun dog owners who had had symptoms which could have been due to Lyme borreliosis, and in participants who recognised EM. This could be because it was not possible to exclude other causes for the symptoms attributed to Lyme borreliosis. The relative absence of antibodies in those who recognised EM could be due to the fact that seven of them had been treated with antibiotics soon after the tick bite. It is known that this can suppress an antibody response to $B$. burgdorferi.

Just as with other groups at risk (Table 2), asymptomatic owners of gun dogs showed a high prevalence of IgG antibodies to $B$. burgdorferi. The predictive value of a positive or negative result of a serological test is dependent upon the probability of Lyme borreliosis before the test. False positive results are more likely to arise if tests for antibodies to $B$. burgdorferi are requested in the absence of a good clinical evaluation. Infectious mononucleosis, rheumatoid arthritis, lupus erythematosus and other spirochete infections, can give rise to false positive results for both $\lg G$ and $\lg M(25)$.

The results of this study indicate that in The Netherlands asymptomatic infections with $B$. burgdorferi are common in individuals highly exposed to ticks and that there is considerable variation in the prevalence of seropositivity in the general population. Hence caution is called for in the clinical interpretation of IgG test results.

\section{Acknowledgements}

The enthusiastic cooperation of the participating members of the "Koninklijke Nederlandse Jagersvereniging" is greatly acknowledged. 


\section{REFERENCES}

1. Wokke JHJ, Vanneste JAL, Vermeulen M, Op de Coul AAW, Overbeek HC, Janssen RMCM, Brouwer R. Lymfocytaire meningoradiculitis na insektebeet (syndroom van Bannwarth). Nederlands Tijdschrift voor Geneeskunde 1984; 128: 1796-1799.

2. van Duin BJ. Erythema chronicum migrans als eerste teken van Lyme-ziekte. Nederlands Tijdschrift voor Geneeskunde 1987; 131; 679-680.

3. van Furth R. Lyme disease: een nieuwe infectieziekte met lokalisatie in verschillende organen. Nederlands Tijdschrift voor Geneeskunde 1987; 131: 657-658.

4. Kuiper $H$, van Doornum GJJ. Lyme disease: een infectie met lokalisatie in verschillende organen. Nederlands Tijdschrift voor Geneeskunde 1987; 131: 1361.

5. Wokke JHJ. Lyme-ziekte. Nederlands Tijdschrift voor Geneeskunde 1987; 131 : 1141.

6. Blaauw AAM, Braat S, van Santen-Hoeufft HM, van der Linden Sj. Cardiologische afwijkingen bij patiënten met Lyme-borreliose. Nederlands Tijdschrift voor Geneeskunde 1988; 132: 2111-2114.

7. Kuiper $H$, de Jongh BM, Senden PJ. Pacemaker-implantatie wegens totaal atrioventriculair block bij Lyme-borreliose. Nederlands Tijdschrift voor Geneeskunde 1988; 132: 2109-2111.

8. van den Hoogen FHJ, Boerbooms AMTh, Rasker JJ, van de Putte LBA. Gewrichtsklachten na tekebeet; Lyme-artritis in Nederland. Nederlands Tijdschrift voor Geneeskunde 1988; 132: 1300-1303.

9. de Koning J, Hoogkamp-Korstanje JAA, van der Linde MR, Crijns HJ. Demonstration of spirochetes in cardiac biopsies of patients with Lyme disease. Journal of Infectious Diseases 1989; 160: 150-153.

10. Houwerzyl J, Root JJ, Hoogkamp-Korstanje JAA. A case of Lyme disease with cardiac involvement in the Netherlands. Infection 1984; 12: 358.

11. van der Meer JWM. Lyme-borreliose, de "Hocus Pas" onder de infectieziekten. Nederlands Tijdschrift voor Geneeskunde 1989; †33: 2214-2216.

12. Steere AC. Lyme disease. New England Journal of Medicine 1989; 321: 586596.

13. Nadal D, Wunderli W, Birner H, Hansen K. Prevalence of antibodies to Borrelia burgdorferi in forestry workers and blood donors from the same region in Switzerland. European Journal of Clinical Microbiology and Infectious Diseases 1989; 8: 992-995.

14. Münchhoff P, Wilske B, Preac-Mursic V, Schierz G. Antibodies against Borrelia burgdorferi in Bavarian forest workers. Zentralblatt für Bakteriologie, Mikrobiologie und Hygiene [A] 1986; 263: 412-419.

15. Guy EC, Bateman DE, Martyn CN, Heckels JE, Lawton NF. Lyme disease: prevalence and clinical importance of Borrelia burgdorferi specific IgG in forestry workers. Lancet 1989; i: 484-486.

16. Baird AG, Gillies JCM, Bone FJ, Dale BAS, Miscampbell NT. Prevalence of antibody indicating Lyme disease in farmers in Wigtownshire. British Medical Journal 1989; 299: 836-837. 
17. Fahrer $\mathrm{H}$, van der Linden SM, Sauvain MJ, Gern L, Zhioua E, Aeschlimann A. The prevalence and incidence of clinical and asymptomatic Lyme borreliosis in a population at risk. Journal of Infectious Diseases 1991; 163: 305-310.

18. Smith PF, Benach JL, White DJ, Stroup DF, Morde DL. Occupational risk of Lyme disease in endemic areas of New York State. Annals of the New York Academy of Sience 1988; 539: 289-301.

19. Fahrer $\mathrm{H}$, Sauvain MJ, van der Linden Sj, Zhioua E, Gern L, Aeschlimann A. Praevalenz der Lyme-Borreliose in einer schweizerischen Risikopopulation. Schweizerische Medizinische Wochenschrift 1988; 118: 65-69.

20. Schmidt R, Gollmer E, Zunser R, Kruger J, Ackermann R. Prevalence of erythema migrans borreliosis in blood donors. Infusionstherapie 1989; 16: 248251.

21. Gustafson R, Svenungsson B, Gardulf A, Stiernstedt G, Forsgren M. Prevalence of tick-borne encephalitis and Lyme borreliosis in a defined Swedish population. Scandinavian Journal of Infectious Diseases 1990; 22: 297-306.

22. Craft JE, Grodzicki RL, Steere AC. Antibody response in Lyme disease: evaluation of diagnostic tests. Journal of Infectious Diseases 1984; 149: 789-795.

23. Barbour AG. Isolation and cultivation of Lyme disease spirochetes. Yale Journal of Biology and Medicine 1984; 57: 521-525.

24. Mautner VF, Gittermann M, Freitag V, Schneider E. Zur Epidemiologie der Borrelia burgdorferi-Infektion. Nervenarzt 1990; 61: 94-97.

25. Rahn DW, Malawista SE. Lyme disease: recommendations for diagnosis and treatment. Annals of Internal Medicine 1991; 6: 472-481. 


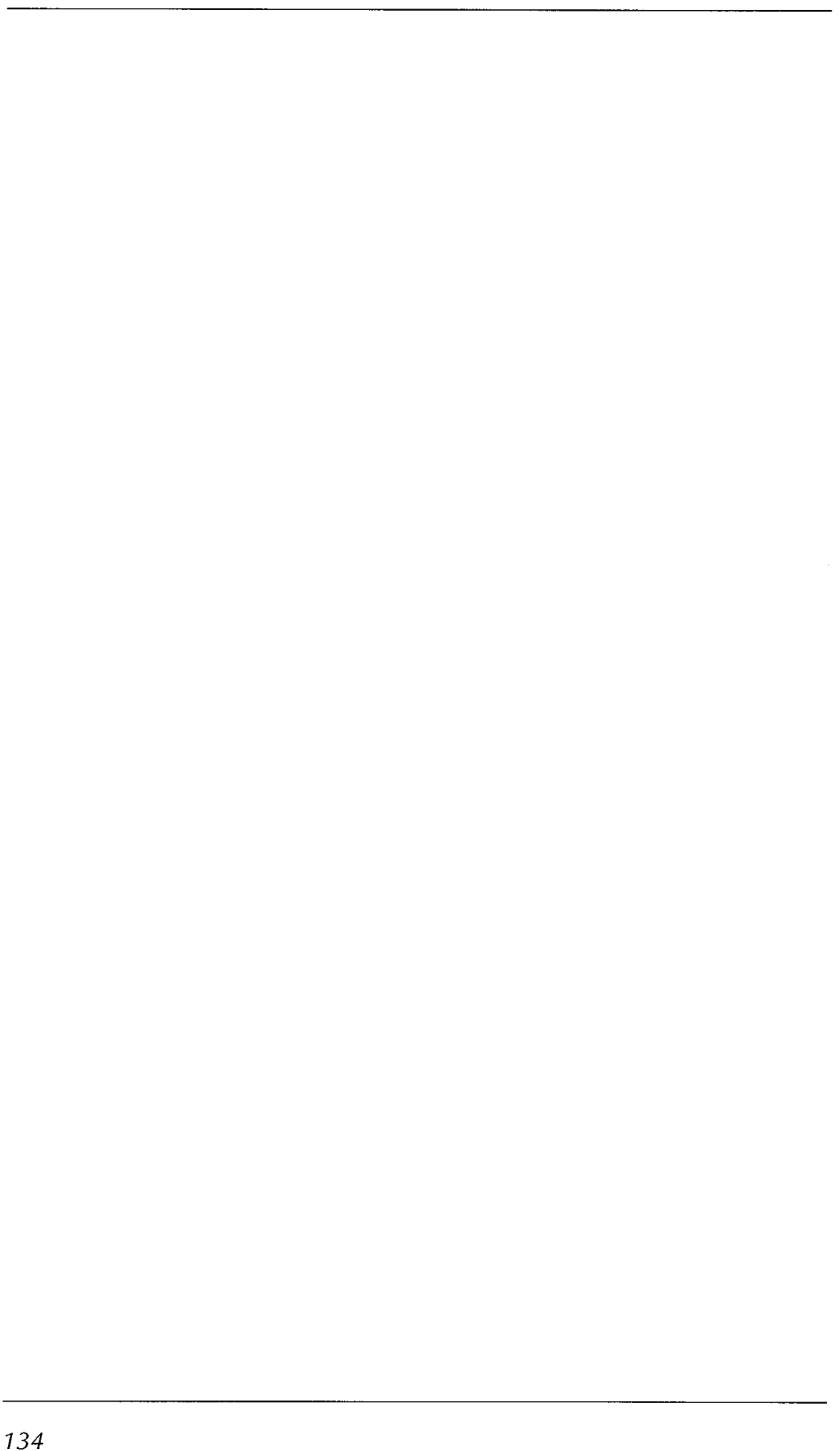


SUMMARY 


\section{SUMMARY}

Lyme borreliosis is an infectious disease that is caused by the bacterium Borrelia burgdorferi which is transmitted by the bite of a tick. The disease was well known in Europe at the turn of this century but it was not until 1981 that the organism was isolated and shown to be the etiological agent. Lyme borreliosis derives its name from a town in Connecticut, USA and is a disease resulting in a plethora of symptoms involving several organ systems. $B$. burgdorferi belongs to the Spirochaetaceae, a family of relative long, thin, helically shaped bacteria. In-vitro cultivation of $B$. burgdorferi is only possible using complex culture media, comparable to those used for tissue cultures. The most widely used artificial medium is the semi-fluid BSKII (Barbour-Kelly-Stoenner) medium. Growth of B. burgdorferi in single colonies on solid media has only incidentically been described.

More than 30 different polypeptides have been demonstrated in $B$. burgdorferi cell-lysates using sodium dodecyl-sulphate (SDS) polyacrylamide gel electrophoresis (SDS-PAGE), including the outer membrane proteins OspA, OspB, and OspC, and the $41 \mathrm{kDa}$ genus specific flagellum protein.

In contrast to most other bacteria $B$. burgdorferi has a linear chromosome. Extrachromosomal DNA which is present in the form of circular and linear plasmids encodes for the outer membrane proteins. Loss of plasmids has been observed after a few in-vitro passages and this phenomenon has been associated with the loss of virulence in laboratory animals. $B$. burgdorferi is heterogeneous. Whereas American $B$. burgdorferi isolates mostly produce an OspA at $31 \mathrm{kDa}$ and an OspB at $34 \mathrm{kDa}$, in European strains OspA varies from $31 \mathrm{kDa}$ to $33 \mathrm{kDa}$ and OspB from $34 \mathrm{kDa}$ to $36 \mathrm{kDa}$. In addition, European strains regularly do not produce an OspB, and OspC is more often seen in European B. burgdorferi isolates than in American strains.

In 1992 B. burgdorferi sensu lato has been split into $B$. burgdorferi sensu stricto, Borrelia garinii and B. burgdorferi group VS461 on the basis of DNA relatedness. In Europe all these three genomic species occur, but in the USA $B$. burgdorferi sensu stricto is the only species found so far. There are indications that the different genomic species of $B$. burgdorferi account for differences in the clinical picture of Lyme borreliosis. $B$. burgdorferi group VS461 has been associated with cutaneous disorders and the other two genomic species have been associated with extracutaneous manifestations of Lyme borreliosis.

Lyme borreliosis is transmitted by hard ticks belonging to the genus /xodes. These ticks are prevalent in all parts of the word with a temperate climate. Whereas in the USA Ixodes scapularis (formerly: Ixodes dammini) is the most important vector of Lyme borreliosis, in The Netherlands and elsewhere in Europe the sheep tick Ixodes ricinus is the most prevalent hard tick. 1. ricinus has a life cycle of about two years. During each of the developmental stages i.e. the larva, the nymph and the adult tick, one blood meal is 
taken. Mice are the main hosts for /xodes ticks and also are the most important reservoir of $B$. burgdorferi. Among mouse species the wood-mouse Apodemus sylvaticus is probably the most important reservoir of $B$. burgdorferi in The Netherlands. In some parts of the USA more than $50 \%$ of $I$. scapularis ticks have shown to be infected with $B$. burgdorferi. In European countries infection rates of 1 . ricinus ranging from $5 \%$ to $34 \%$ for nymphs and from $11 \%$ to $34 \%$ for adult ticks have been reported. The risk of acquiring clinical Lyme borreliosis after the bite of an infected tick has been estimated to be $2-4 \%$. In Europe the risk of acquiring clinical Lyme borreliosis after a tick bite is about $1 \%$.

Lyme borreliosis progresses in three stages with different signs and symptoms at each stage. However, these stages are a reflection of the extent of the disease and do not necessarily follow a chronological progression, so it is more appropriate to divide the disease into an early and a late stage. The early stage corresponds with stage 1 (localized infection) and stage 2 (disseminated infection). The late stage corresponds to stage 3 and marks persistent infection. The organ systems most often affected are the skin, the musculoskeletal system, the nervous system and the heart. Three separate dermatological conditions are associated with Lyme borreliosis: erythema migrans, lymphadenosis benigna cutis and acrodermatitis chronica atrophicans. Erythema migrans, the most frequently occurring manifestation of early Lyme borreliosis, is a ring-shaped erythematous and usually peripherally expanding skin lesion with central clearing that first occurs at the site of the tick bite. Lymphadenosis benigna cutis results from dissemination of $B$. burgdorferi and is characterized by a bluish-red tumour-like infiltrate with lymphoreticular proliferation in the skin. Acrodermatitis chronica atrophicans, a late manifestation of Lyme borreliosis, is characterized by atrophic changes of the skin usually at the site of the causative tick bite. This condition is rarely seen in the USA.

Arthralgia and myalgia, which are typically intermittent, are the most frequently occurring rheumatological manifestations of Lyme borreliosis. Months to years after the onset of infection patients may develop arthritis. Lyme arthritis is typically mono- or oligoarticular and localized in large joints. The knee is most often affected. There are indications that Lyme arthritis more often occurs in the USA than in Europe.

There is a broad range of neurological manifestations associated with Lyme borreliosis. However, the most frequently occurring condition is Bannwarth's syndrome (meningoradiculoneuritis). This syndrome has clinically been defined as radicular pain, with CSF lymphocytic pleocytosis, with or without peripheral nerve pareses and with or without cranial nerve affection. In Europe neurological manifestations of Lyme borreliosis are more frequently seen than in the USA.

Cardiac involvement is less common than either skin, musculoskeletal or neurological manifestations. The most common abnormalities are rhythm and conduction disturbances. 
Laboratory methods for the diagnosis of Lyme borreliosis either intend to detect the causative agent or to measure a specific immune response against $B$. burgdorferi. Detection of $B$. burgdorferi is possible by means of microscopy, antigen detection, culture, and DNA techniques. However, these methods are not (yet) useful in routine clinical practice because they have too low a sensitivity, are laborious and time-consuming, are only suitable for tissue biopsies, and/or are not commercially available.

$B$. burgdorferi induces a humoral and a cellular immune response. The initial immune response is mediated by T-cells. The T-cell response is followed by the production of specific antibodies by B-cells. Detection of an immune response against $B$. burgdorferi is possible using T-cell proliferation assays but the specificity of these tests is not yet clear. T-cell proliferation assays require fresh cells, are laborious, and difficult to standardize.

At present measuring antibodies to $B$. burgdorferi is the only practical method for the laboratory diagnosis of Lyme borreliosis. However, several problems are encountered with Lyme serology. The antibody response to $B$. burgdorferi is slow. The primary immune response to $B$. burgdorferi is directed against the $41 \mathrm{kDa}$ flagellum protein. Later in the course of infection antibodies occur against a broad range of other $B$. burgdorferi proteins, either specific or nonspecific. IgM antibodies may not be detectable until six weeks after the onset of infection. IgG antibodies may not peak before months after onset of the disease and generally persists for years. Antibiotic treatment early in the course of infection may prevent the development of a measurable immune response. False-positive results are due to cross-reactivity of $B$. burgdorferi with other bacteria, mainly Borrelia species and treponemas, or in viral infections or auto-immune diseases. Lyme borreliosis may be asymptomatic, especially in patients who are at increased risk of infestation by ticks.

The most commonly used serological tests for Lyme borreliosis are IFA (immunofluorescent antibody assay), EIA (enzyme immunoassay) and Western immunoblot. IFA has an advantage over EIA in that false-positive results may be distinguished by an abnormal fluorescence pattern provided the test is performed by experienced laboratory personnel. With EIA the problem of subjectivity is circumvented by reading the results colorimetrically. To increase the specificity of IFA and EIA preadsorption of serum samples and/or the use of purified antigens have been advocated. Western immunoblot has the advantage of detecting antibodies to individual $B$. burgdorferi proteins. Some authors have judged this assay to be a specific confirmatory test for Lyme borreliosis. However, the experiences with in-house and commercially available assays for Lyme borreliosis including IFA, EIA and Western immunoblot, vary. The main problem with these assays is the lack of standardization, the heterogeneity of $B$. burgdorferi and the unique immune response in Lyme borreliosis. 
Lyme borreliosis is the most common tick-borne transmitted disease in the USA and in Europe. In Europe the estimated incidence of the disease is $0.05-0.1 \%$ per 100.000 inhabitants per year. After the discovery of $B$. burgdorferi it has become clear that in The Netherlands the whole clinical spectrum of Lyme borreliosis can be encountered.

This study intends to get insight into the infection rate of the vector and into the prevalence of Lyme borreliosis in The Netherlands. Another aim of the study was to evaluate the validity of various assays for the serological diagnosis of Lyme borreliosis.

In Chapter 2 the growth characteristics of $B$. burgdorferi in artificial media were explored. Among the media used to recover B. burgdorferi, the BSKII medium is the most widely used. However this medium is complex and subject to variable quality because of the necessity of adding rabbit serum which is an undefined substrate. Therefore an investigation was undertaken to see whether or not this supplement could be omitted without impairing optimal growth. The growth curves of the reference strain $B$. burgdorferi B31 first isolated in the USA from a tick were similar in complete media and in media without rabbit serum provided that impure bovine serum albumin is used and that neopeptone had been boiled rather than left to dissolve at ambient temperatures.

Since a selective medium was needed in order to isolate $B$. burgdorferi from ticks, the effect of adding neomycin $100 \mathrm{mg} / \mathrm{L}$, sulphamethoxazole $256 \mathrm{mg} / \mathrm{L}$ and trimethoprim $64 \mathrm{mg} / \mathrm{L}$ on the detection level of spirochetes was determined. An inoculum of only two spirocietes of a low-passage strain of $B$. burgdorferi isolated from a Dutch tick could be recovered with this medium. However, despite the ability to stimu ate the growth of only a few spirochetes, the recovery rate of $B$. burgdorfeli derived from the tissue of experimentally infected rats was still better in antibiotic-free medium than in the selective medium, suggesting that selection is only achieved at the cost of reduced sensitivity.

The ability to yield isolated colonies is the sine qua non of microbiology since only then can the purity of the cultures be established making further investigation possible. The addition of $1.25 \%$ of the gelling agent agarose to BSKII medium yielded the best results in terms of single colonies and colony diameter. On this medium the high-passage strains $B$. burgdorferi B31 and PKo (a German skin isolate), and a Dutch low-passage tick isolate formed discrete colonies but only after 14 days incubation at $34^{\circ} \mathrm{C}$ anaerobically making the solid medium unsuitable for rout:ne diagnostic use. However, this medium may be quite useful for cloning purposes and to obtain relative large amounts of antigen for serological tests.

It was also important to establish whether repeated passage of $B$. burgdorferi resulted in changes in the protein profile, reactivity with monoclonal antibodies (MAbs), PCR (polymerase chain reaction) fingerprints and virulence in laboratory animals and, if so, how this was related to different arti- 
ficial culture media. Three Dutch low-passage tick isolates of $B$. burgdorferi, $B$. burgdorferi B31, and B. burgdorferi $\mathrm{PKo}$ were each passaged 40 times in BSKII medium with and without rabbit serum. The protein profiles were then determined using SDS-PAGE with the gels being coloured by CoomassieBlue. The reactivity of MAbs was determined against flagellin by MAb $\mathrm{H} 9724$, OspA by MAbs H5332 and H3TS, and OspB by MAb H6831. Random amplified polymorphic DNA PCR (RAPD-PCR) fingerprinting was employed to compare genotypes. No alterations were detected among any of the five strains. However, each of the three Dutch low-passage tick isolates of $B$. burgdorferi lost their infectivity to 3-week old Lewis/M rats from which samples of the skin, bladder, kidneys, spleen and brain failed to yield any bacteria as would otherwise have been expected. Therefore, there was no relationship between the loss of infectivity and alterations in outer membrane proteins in contrast to what has been reported hitherto. However, the stability of the phenotypic and genotypic properties despite in-vitro passage agrees with the observation that neither EIA nor Western immunoblot are influenced significantly by the choice of strain used to prepare antigens.

In order to establish the infection rate of I. ricinus in The Netherlands (Chapter 3), 1838 ticks were collected during June and September of 1989 from 20 locations in 10 provinces (no ticks were collected in Groningen and Flevoland). Ticks were collected by dragging white flannel towels over the low vegetation, a method known as flagging. Samples were taken in and around the places where people encounter the greatest risk of infection such as footpaths, parking lots and verges adjacent to woodlands, dunes and heaths. Each tick was identified visually and separated in nymphs and adults. Four nymphs at a time were homogenised in a few drops of culture medium whereas adults were treated individually. The suspensions were inoculated into the selective BSKII medium developed in Chapter 2. Motile spirochetes indistinguishable from $B$. burgdorferi were mostly seen after 2 to 3 weeks incubation. The extra yield of positive samples after incubation for longer than six weeks was only $1.3 \%$. Seventy-five out of the 659 samples were positive, 37 of which were from the nymphs giving a minimum infection rate for nymphs of $2.4 \%$. The infection rate for adult ticks was $14.3 \%$. Only 63 isolates were tested against serum from a patient with Lyme borreliosis and all produced a positive reaction. Infected nymphs and/or adult ticks were found in every province where ticks were collected. In Sittard (Limburg), Den Burg (Texel) and Oldeberkoop (Friesland) the minimum infection rates for nymphs were 8,9 and $15 \%$ respectively. Rates of infection for nymphs in the other 17 locations ranged between $0 \%$ and $4 \%$. No adult ticks were collected in Drenthe, so when this province was left out of consideration, the rates of infection for adult ticks varied from $0 \%$ in Gelderland and Zeeland to $30 \%$ on the island of Texel. These data are very similar to those reported elsewhere in Western Europe but once the sensitivity of the method of detection is taken into consideration, the actual infection rate among ticks may be higher since both IFA and PCR are 1.5 to 2 times more sensitive than culture. 
These 63 strains isolated from ticks together with three skin isolates of Dutch patients with Lyme borreliosis were subjected to genotyping and phenotyping using restriction fragment length polymorphism (RFLP), Coomassie-blue staining of SDS-PAGE and reactivity with MAbs (Chapter 4). B. burgdorferi B31 (genomic species: B. burgdorferi sensu stricto) and B. burgdorferi PKo (genomic species: group VS461) were used as controls. Before Southern blotting, bacterial DNA was fragmented by means of the endonucleases HindIII and EcoRV. The resulting DNA segments were hybridized with 16S+23S RNA ( $\mathrm{rRNA}$ ) derived from Escherichia coli and with a 730 base pair fragment of the flagellin gene of $B$. burgdorferi B31. Phenotypes were determined from the SDS-PAGE profiles obtained from the $30-36 \mathrm{kDa}$ OspA and $\mathrm{OspB}$ and the $20-25 \mathrm{kDa}$ OspC together with the reactivity to anti-flagellin MAb H9724, anti-OspA MAbs H9724 and H3TS, and anti-OspB H6831. All three human skin isolates belonged to $B$. burgdorferi group VS461. This finding is in agreement with recent reports that group VS461 is mainly isolated from skin lesions. Of the 63 tick isolates $29(46 \%)$ were assigned to $B$. burgdorferi sensu stricto, $19(30 \%)$ to $B$. garinii and two $(3 \%)$ to $B$. burgdorferi group VS461. The remaining 13 tick isolates $(21 \%)$ exhibited a rRNA gene restriction pattern that deviated from the three established genomic species. Twelve of these isolates formed a distinct group, designates as M19. This group is similar to $B$. garinii but could be discriminated by hybridization with the flagellin probe which was a conserved part of the genome coding for the flagellar protein that lay $250 \mathrm{kbp}$ away from the rRNA gene cluster. One of the 63 isolates possessed a quite different rRNA restriction pattern from the others. The genotypic classification of the 66 Dutch strains of $B$. burgdorferi corresponded only partly with that based on protein profiles and reactivity with MAbs which did not allow $B$. garinii to be differentiated from B. burgdorferi group M19.

The prevalence of $B$. burgdorferi sensu stricto, $B$. garinii and $B$. burgdorferi group VS461 among I. ricinus in The Netherlands is comparable to that found in other parts of Europe. The finding that $B$. burgdorferi sensu lato probably contains more than three genomic species is particularly important in the light of recent reports indicating that different genomic species of $B$. burgdorferi are responsible for the different clinical pictures of Lyme borreliosis and that $B$. garinii is mainly associated with extracutaneous manifestations of the disease. Further investigation is therefore warranted to establish the status of $B$. burgdorferi group M19.

Nine serological tests for diagnosing Lyme borreliosis are evaluated for their sensitivity, specificity, intra- and inter-test precision and their relative cost (Chapter 5). To this end, 200 sera were obtained from patients in six well defined clinical categories. For assessing sensitivity, serum had been collected from 13 patients in the early stage of Lyme borreliosis and 21 patients in the late stage of their disease. All patients in the early Lyme borreliosis group had erythema migrans. The patients in the late Lyme borreliosis group had suffered from erythema migrans but subsequently had developed arthralgia $(n=4)$, arthritis $(n=15)$ or acrodermatitis chronica atrophicans $(n=2)$. Sera were also obtained from 36 Swiss cross-country 
runners none of whom had any obvious sign or symptom of Lyme borreliosis but all of whom were regularly bitten by ticks and were therefore at high risk of infection. Moreover, their sera contained IgG which reacted with a Swiss EIA test comprising a whole-cell sonicate of $B$. burgdorferi. For assessing specificity, sera were obtained from 15 patients with rheumatoid factor (RF) positive rheumatoid arthritis and 31 patients with syphilis. In addition, sera were collected from 84 healthy individuals without any history suggesting Lyme borreliosis.

Five of the diagnostic tests were obtained from commercial sources of which four were based on EIA. The EIA test of Dako detects IgG in unadsorbed sera by employing the purified native flagella of a human $B$. burgdorferiskin isolates. The EIA of Diamedix detects both $\operatorname{lgG}$ and $\lg M$ in preadsorbed sera and employs a flagellin enriched antigen preparation of $B$. burgdorferi B31. The Whittaker EIA is based on a whole-cell sonicate of $B$. burgdorferi B31 and also detects both IgG and IgM but the test serum is not adsorbed beforehand. With the EIA test of Diagast IgG is detected in preadsorbed test serum by means of various components of $B$. burgdorferi B31 as the antigen, including the $41 \mathrm{kDa}$ and the $100 \mathrm{kDa}$ proteins as well as OspA and OspB proteins. The fifth commercial test was also obtained from Diagast to detect both IgG and IgM by agglutination of sheep erythrocytes carrying flagellar and outer membrane proteins of $B$. burgdorferi B31.

The four remaining tests were home-made and designed to detect IgG in unadsorbed serum as well as serum that had been treated with a sonicate of Treponema phagedenis to reduce cross-reactivity. The antigen for the EIA was prepared from a whole-cell sonicate of $B$. burgdorferi B31 and that for IFA comprised intact cells of the organism.

When diagnosing Lyme borreliosis in the early stage, the EIA of Dako exhibited the highest sensitivity, albeit only $62 \%$ and the Diagast haemagglutination assay was the least sensitive yielding $8 \%$ sensitivity. The sensitivities of the other tests were $54 \%$ for the EIA of Diamedix and the homemade EIA with adsorbed serum, 31\% for both home-made IFA tests and the EIA of Whittaker. The tests were more sensitive when diagnosing disease in the late stage and, although the haemagglutination assay of Diagast and the EIA of Whittaker produced a sensitivity of $62 \%$ and $71 \%$ respectively, the other seven afforded a sensitivity of $86 \%$. All 36 sera of the asymptomatic Swiss cross-country runners were positive with the home-made EIA tests and the home-made IFA which employed adsorbed serum, five tests afforded lower sensitivities and only 10 of the samples were positive with the haemagglutination assay of Diagast. A specificity of at least $93 \%$ and 95\% was obtained for all tests performed on the sera of patients with rheumatoid arthritis and healthy controls respectively. However, the specificity of the home-made EIA on the unadsorbed sera of patients with syphilis was only $29 \%$ compared with the corresponding specificities of the other tests which ranged from $68 \%$ to $100 \%(p<0.05)$.

The within-run and the run-to-run variation varied among the EIA tests evaluated with coefficients of variation being $3-14 \%$ and $11-23 \%$ respectively. The low sensitivity of the haemagglutination test of Diagast precludes its use for diagnosing Lyme borreliosis whereas the EIA tests of Dako and 
Diamedix are attractive alternatives to home-made tests when sensitivity, specificity, precision, ease-of-use and cost are taken into account.

As each of the above tests may give false-positive results, a confirmatory test is required such as Western immunoblotting. In order to assess the value of this technique, sera for which the EIA results were known were obtained from 31 patients in the early stage of the disease, 48 patients in the late stage and 86 patients with diseases that may share similar clinical features to Lyme borreliosis and need to be differentiated from the infection (Chapter 6). This latter group included patients who had RF-positive rheumatoid arthritis $(n=21)$, ankylosing spondylitis $(n=18)$, psoriatic arthritis $(n=9)$, reactive arthritis $(n=4)$, systemic lupus erythematosus $(n=5)$, arthritis of unknown origin $(n=9)$ or syphilis $(n=20)$. The sera of 44 healthy individuals without any history suggesting Lyme borreliosis were also included as negative controls. The antigen for the Western immunoblot was the same as that used for the home-made EIA namely, a whole-cell sonicate of $B$. burgdorfe$r i$ B31. The test was evaluated using logistic regression analysis whereby $\mathrm{kDa}$ ranges served as the independent variables rather than the individual $\mathrm{kDa}$ values themselves. This method was chosen because assigning exact $\mathrm{kDa}$ values to individual immunoblot bands is difficult and highly subjective. Fifty of the 79 sera of patients with Lyme borreliosis proved positive by Western immunoblot and 55 by EIA and although the difference was not statistically significant, the correlation coefficient between the two tests was only 0.41 . However, Western immunoblot generated only $10 \%$ false-positive results in the sera of healthy controls and of patients with other diseases, whereas EIA generated $43 \%$ false-positive results. The significant improvement in test performance provided by the Western immunoblot appeared independent of the number of bands, the character of the band nor its intensity when these were included in the regression model. However, the Western immunoblot test cannot be considered specific enough to confirm the diagnosis of Lyme borreliosis especially as 11 out of 86 patients with diseases that might be confused with Lyme borreliosis (13\%) were still diagnosed positive. Moreover, the test performance is similar to some of the commercially available EIA tests and so careful consideration is required before the technique is selected for routine use as an alternative to EIA.

Little is known of the prevalence of symptomatic and quiescent Lyme borreliosis among the general population and those at high risk of infection in The Netherlands. Therefore, the sera of 1,052 blood donors were collected from 10 blood banks to represent the general population and blood was obtained from 440 members of the Dutch Hunting Association who formed a high risk group because of increased risk of being infested by ticks (Chapter 7). The hunters were shown photographs of erythema migrans lesions and asked to fill in a questionnaire which enquired about the frequency of tick bites and about symptoms which could possibly be attributed to Lyme borreliosis. The ratio of blood donors to hunters within the postal area of each blood bank was at least 2:1 for each age group and for each sex. Antibodies to $B$. burgdorferi were determined using the home-made EIA without preadsorption of sera described in Chapter 5 . Almost $15 \%$ of hunt- 
ers were shown to have IgG antibodies to $B$. burgdorferi compared with $9 \%$ of blood donors $(p=0.0002)$. In both groups, the proportion of individuals with antibodies rose with age from none to $3 \%$ of those under 20 years old to $12 \%$ and $27 \%$ of those older than 59 years for blood donors and hunters respectively. There was no difference between the sexes nor between hunters from different areas. However, there was marked regional variation among blood donors with $2 \%$ of those from Groningen having antibodies and as many as $17 \%$ from Leiden. Only $3 \%$ of hunters and 4 of the 68 who were seropositive $(6 \%)$ had any history of clinical signs and symptoms most probably due to Lyme borreliosis. Therefore, at least in The Netherlands, while asymptomatic infection frequently occurs in those regularly exposed to the risk of tick bites, there exists a marked regional variation among the general population. It also would seem futile to attempt to detect antibodies to $B$. burgdorferi unless there are clinical indications for doing so. 
SAMENVATTING 


\section{SAMENVATTING}

Lyme borreliose is een infectieziekte die wordt veroorzaakt door de bacterie Borrelia burgdorferi welke wordt overgebracht door de beet van een teek. Hoewel B. burgdorferi pas voor het eerst werd geïsoleerd in 1981 in de Verenigde Staten, werden in Europa al sinds het begin van deze eeuw ziektebeelden beschreven en geassocieerd met tekebeten waarvan nu duidelijk is dat ze het gevolg zijn van een infectie met deze bacterie. Lyme borreliose ontleent zijn naam aan de plaats Lyme in Connecticut, Verenigde Staten, en is een multisystemische ziekte met een breed scala klinische manifestaties.

B. burgdorferibehoort tot de Spirochaetaceae, een familie van relatief lange dunne spiraalvormige bacteriën. In-vitro groeit $B$. burgdorferi uitsluitend in complexe kweekmedia, vergelijkbaar met die voor weefselkweken. Het meest toegepaste kweekmedium is het semi-vloeibare BSKII (Barbour-KellyStoenner) medium. Groei van B. burgdorferi in losliggende kolonies op een vaste voedingsbodem is maar incidenteel beschreven.

Met behulp van "sodium dodecyl-sulphate" (SDS) "polyacrylamide gel electrophoresis" (SDS-PAGE) zijn in sonicaten van B. burgdorferi meer dan 30 eiwitten aangetoond. Hieronder bevinden zich de buitenmembraan eiwitten OspA, OspB en OspC en het $41 \mathrm{kDa}$ genus specifieke flagelline eiwit. In tegenstelling tot de meeste andere bacteriën heeft $B$. burgdorferi een Iineair chromosoom. Extrachromosomaal DNA dat aanwezig is in de vorm van lineaire en circulaire plasmiden codeert voor de buitenmembraan eiwitten. Tijdens in-vitro passage van $B$. burgdorferi kunnen plasmiden verloren gaan. Verlies van plasmiden wordt geassocieerd met verlies van infectiviteit voor proefdieren. B. burgdorferi is heterogeen. Amerikaanse B. burgdorferi isolaten produceren een OspA en een OspB van respectievelijk 31 $\mathrm{kDa}$ en $34 \mathrm{kDa}$. Bij Europese stammen varieert het OspA van 31 tot $33 \mathrm{kDa}$ en het OspB van 34 tot $36 \mathrm{kDa}$. Europese isolaten produceren niet altijd een OspB terwijl OspC vaker voorkomt bij Europese dan bij Amerikaanse isolaten. Sinds 1992 wordt $B$. burgdorferi sensu lato op basis van DNA verwantschap onderverdeeld in $B$. burgdorferi sensu stricto, Borrelia garinii en $B$. burgdorferi groep VS461. In de Verenigde Staten komt alleen B. burgdorferi sensu stricto voor. In Europa worden alle drie de genospecies aangetroffen. Er zijn aanwijzingen dat de verschillende genospecies van $B$. burgdorferiverantwoordelijk zijn voor verschillen in het klinische beloop van Lyme borreliose. B. burgdorferi groep VS461 wordt geassocieerd met cutane manifestaties van de ziekte en de andere twee genospecies voornamelijk met extracutane verschijnselen.

Lyme borreliose wordt overgebracht door harde teken behorend tot het genus Ixodes. Deze teken worden aangetroffen in gebieden met een gematigd klimaat. In de Verenigde Staten is Ixodes scapularis (vroeger Ixodes dammini genoemd) de belangrijkste vector van Lyme borreliose. In Nederland 
en elders in Europa is Ixodes ricinus (in de volksmond "gewone teek" of "schapeteek" genoemd) de meest voorkomende harde teek. l. ricinus kent een levenscyclus van ongeveer twee jaar waarin larven zich via nimfen ontwikkelen tot volwassen mannelijke en vrouwelijke teken. In elk ontwikkelingsstadium neemt de teek eenmaal een bloedmaaltijd. De belangrijkste gastheer en tevens reservoir voor B. burgdorferi is de muis. Groter wild, huisdieren en de mens zijn toevallige gastheren. In Nederland is de bosmuis Apodemus sylvaticus waarschijnlijk het belangrijkste reservoir voor $B$. burgdorferi. In sommige gebieden van de Verenigde Staten is de besmettingsgraad van $I$. scapularis met B. burgdorferi groter dan $50 \%$. In Europese landen varieert het besmettingspercentage van I. ricinus van $5 \%$ tot $34 \%$ voor nimfen en van $11 \%$ tot $34 \%$ voor volwassen teken. De kans op klinische Lyme borreliose na de beet van een besmette teek wordt geschat op $2-4 \%$. In Europa is de kans op klinische Lyme borreliose na een tekebeet ongeveer $1 \%$.

Het beloop van Lyme borreliose kent drie stadia, die gekenmerkt worden door verschillen in symptomatologie. Aangezien de stadia elkaar kunnen overlappen en een of meerdere stadia subklinisch kunnen verlopen, is de indeling in vroege en late Lyme borreliose gangbaar geworden. Het vroege stadium komt overeen met stadium 1 (gelokaliseerde infectie) en stadium 2 (gedissemineerde infectie). Het late stadium komt overeen met stadium 3 (persisterende infectie). De orgaansystemen die het meest vaak zijn aangedaan zijn de huid, het bewegingsapparaat, het zenuwstelsel en het hart. Lyme borreliose kent drie dermatologische manifestaties: erythema migrans, lymphadenosis benigna cutis en acrodermatitis chronica atrophicans. Erythema migrans is een ringvormige erythemateuze lesie met centrifugale uitbreiding en centrale verbleking die ontstaat op de plaats van de tekebeet. Erythema migrans is de meest voorkomende manifestatie van vroege Lyme borreliose. Lymphadenosis benigna cutis komt voor bij gedissemineerde Lyme borreliose. Deze huidafwijking is gekenmerkt door een paars-rood tumorachtig infiltraat met lymforeticulaire proliferatie in de huid.

Acrodermatitis chronica atrophicans is een late manifestatie van Lyme borreliose en is gekenmerkt door atrofie van de huid in het gebied van de oorzakelijke tekebeet. In de Verenigde Staten wordt acrodermatitis chronica atrophicans zelden gezien.

Arthralgieën en myalgieën zijn de meest voorkomende rheumatologische manifestaties van Lyme borreliose. De arthralgieën en myalgieën zijn typischerwijs intermitterend. Maanden tot jaren na het begin van de infectie kunnen aanvallen van arthritis optreden. Lyme arthritis is typischerwijs monoof oligoarticulair en gelokaliseerd in de grote gewrichten, waarbij de knie het meest vaak is aangedaan.

Er zijn aanwijzingen dat Lyme arthritis vaker voorkomt in de Verenigde Staten dan in Europa.

Lyme borreliose is geassocieerd met een breed scala neurologische manifestaties waarbij het syndroom van Bannwarth (meningoradiculoneuritis) het meest frequent voorkomt. Het syndroom van Bannwarth is gekenmerkt door radiculaire pijn met een verhoogd aantal lymfocyten in de liquor, al dan 
niet in combinatie met perifere paresen en al dan niet in combinatie met ontsteking van de hersenzenuwen. Neurologische manifestaties van Lyme borreliose worden in Europa vaker gezien dan in de Verenigde Staten. Hartklachten als manifestatie van Lyme borreliose komen minder vaak voor dan afwijkingen van de huid, het zenuwstelsel en de gewrichten. De meest voorkomende cardiale verschijnselen zijn ritme- en geleidingsstoornissen.

Laboratorium methoden voor de diagnostiek van Lyme borreliose berusten op het aantonen van het oorzakelijk microorganisme of op het aantonen van een specifieke immuun respons tegen $B$. burgdorferi. Detectie van $B$. burgdorferi is mogelijk met behulp van microscopie, antigeen testen, kweek en DNA technieken. Deze methoden zijn echter (nog) niet geschikt voor de "routine" diagnostiek omdat ze onvoldoende gevoelig, moeizaam en tijdrovend, alleen toepasbaar zijn op weefsels, onvoldoende uitgetest en/of niet commercieel verkrijgbaar zijn.

B. burgdorferi induceert een humorale en een cellulaire immuun respons. De cellulaire respons (T-cell respons) ontstaat het eerst en wordt gevolgd door de produktie van specifieke antilichamen door B-cellen. Aantonen van een immuun respons tegen $B$. burgdorferi is mogelijk met behulp van de Tcell proliferatie test, maar de specificiteit van deze test in nog onduidelijk. Voor de T-cell proliferatie test zijn verse cellen nodig, de test is arbeidsintensief en moeilijk te standaardiseren.

De meest praktische methode voor de diagnostiek van Lyme borreliose is het aantonen van antilichamen tegen $B$. burgdorferi. Helaas kent Lyme serologie een aantal problemen. De immuun respons tegen $B$. burgdorferi is traag. De eerste antilichaam respons is gericht tegen het $41 \mathrm{kDa}$ flagelline eiwit. Later in het beloop van de ziekte worden antilichamen gevormd tegen een groot aantal andere eiwitten, zowel $B$. burgdorferi specifieke als niet-specifieke. IgM antilichamen zijn regelmatig pas aantoonbaar 6 weken of later na het begin van de infectie. IgG antilichamen vertonen soms pas na maanden een piek en kunnen jarenlang aantoonbaar blijven. Antimicrobiële therapie in het vroege stadium van de ziekte voorkomt de vorming van antilichamen. Vals-positieve resultaten komen voor ten gevolge van kruisreactiviteit met andere bacteriën, voornamelijk Borrelia soorten en treponemata, of bij virale infecties en autoimmuun ziekten. Asymptomatische (seropositieve) Lyme borreliose komt voor met name bij personen met een verhoogd risico op tekebeten.

De meest toegepaste methoden voor de serologische diagnostiek van Lyme borreliose zijn IFA (immuno fluorescent antibody assay), EIA (enzyme immunoassay) en Western immunoblot. IFA heeft het voordeel dat valspositieve resultaten kunnen worden herkend aan een afwijkend fluorescentie patroon mits de test wordt uitgevoerd door ervaren laboratorium medewerkers. Bij de EIA wordt het probleem van de subjectiviteit omzeild doordat de resultaten colorimetrisch worden bepaald. Om de specificiteit van IFA en EIA te verhogen wordt preadsorptie van sera en/of gebruik van 
gezuiverde antigenen aanbevolen. Western immunoblot heeft het voordeel dat individuele antilichamen tegen $B$. burgdorferi kunnen worden aangetoond. Deze test wordt door sommige auteurs beschouwd als specifieke confirmatietest voor Lyme borreliose. De ervaringen met zelf opgezette en commercieel verkrijgbare serologische testen inclusief IFA, EIA en Western blot zijn wisselend. Als belangrijkste oorzaak hiervoor kan worden aangemerkt het gebrek aan standaardisatie, de heterogeniciteit van B. burgdorferi en de wisselende immuunrespons bij Lyme borreliose.

Lyme borreliose is de meest voorkomende door teken overgebrachte infectieziekte in de Verenigde Staten en in Europa. In Europa wordt de incidentie van Lyme borreliose geschat op 0.05 tot $0,1 \%$ per 100.000 inwoners per jaar. Sinds de ontdekking van $B$. burgdorferi is duidelijk geworden dat in Nederland het hele klinische spectrum van Lyme borreliose voorkomt.

Deze studie beoogt inzicht te verschaffen in de besmettingsgraad van de vector en in de prevalentie van Lyme borreliose in Nederland. Daarnaast wordt beoogt inzicht te krijgen in de waarde van de verschillende testen voor de serologische diagnostiek van Lyme borreliose.

In Hoofdstuk 2 wordt antwoord gegeven op een aantal vragen met betrekking tot de isolatie en kweek van B. burgdorferi.

1. Is het mogelijk om konijneserum, een niet gedefinieerd substraat, weg te laten uit het gangbare BSKII kweekmedium voor B. burgdorferi zonder verlies van optimale groei.

2. Wat is de sensitiviteit van de in Hoofdstuk 3 toegepaste methode voor de isolatie van $B$. burgdorferi uit $I$. ricinus met behulp van BSKII medium waaraan antibiotica zijn toegevoegd.

3 . Is het mogelijk om op een vast BSKII kweekmedium losliggende $B$. burgdorferi kolonies te verkrijgen.

4. Gaat in-vitro passage van $B$. burgdorferi gepaard met veranderingen in het eiwitprofiel, reactiviteit met MAbs (monoclonal antibodies), PCR (polymerase chain reaction) "fingerprints" of infectiviteit, en zijn eventuele veranderingen gerelateerd aan het toegepaste kweekmedium.

De eerste vraag werd beantwoord door vergelijking van de groeicurves van B. burgdorferi B31 (Amerikaanse referentiestam geïsoleerd uit een teek) in het complete BSKII medium en in vier BSKII modificaties. BSKII zonder toevoeging van konijneserum is gelijkwaardig aan het complete BSKII medium mits het toegevoegde bovine serum albumine (BSA) preparaat van een onzuivere kwaliteit is en de toegevoegde neopepton wordt opgekookt in plaats van opgelost in koud water. De waarneming dat $B$. burgdorferi soms kan worden geïsoleerd in konijneserum-vrij BSKII maar niet in compleet BSKII geeft aan dat het zinvol is om deze media naast elkaar te gebruiken, teneinde de gevoeligheid van de kweek te verhogen.

Om de tweede vraag te beantwoorden werd een "low-passage" Nederlands 1. ricinus isolaat gebruikt. Een inoculum van slechts twee spirocheten was 
nodig voor propagatie van dit isolaat in het selectieve BSKII medium met neomycine (100 mg/L), sulfamethoxazole $(256 \mathrm{mg} / \mathrm{L})$ en trimethop rim (64 $\mathrm{mg} / \mathrm{L}$ ). Ondanks deze relatief lage detectiegrens was de opbrengst van $B$. burgdorferi uit weefsels van experimenteel geïnfecteerde ratten hoger in BSKII zonder antibiotica dan in het selectieve BSKII medium. Deze bevinding geeft aan dat toevoeging van antibiotica ten koste gaat van de kweekopbrengst.

Ter beantwoording van de derde vraag werd agar of agarose in verschillende concentraties toegevoegd aan het vloeibare BSKII medium. De media werden beent met de "high-passage" isolaten B. burgdorferi B31 en PKo (Duits humaan huidisolaat), en met een "low-passage" Nederlands $I$. ricinus isolaat. De beste resultaten in termen van losliggende kolonies en kolonie diameter werden waargenomen op BSKII met 1,25\% agarose na 14 dagen incubatie bij $34^{\circ} \mathrm{C}$ onder anaerobe omstandigheden (GasPak). Deze bewerkelijke en tijdrovende kweekmethode is vooralsnog niet geschikt voor diagnostische doeleinden. De toepassingsmogelijkheden moeten met name worden gezocht in het cloneren van $B$. burgdorferi en in het verkrijgen van relatief grote hoeveelheden antigeen ten behoeve van serologische testen voor Lyme borreliose.

Om de vierde vraag te bantwoorden werden drie "low-passage" isolaten, verkregen uit $I$. ricinus teken in Nederland, veertig keer "gepasseerd" in BSKII met en zonder konijneserum. Als controle dienden de laboratorium geadapteerde stammen B31 en PKo. Voor bepaling van de eiwitprofielen werden SDS-PAGE gels gekleurd met "Coomassie blue". De MAb reactiviteit werd bepaald met behulp van anti-flagelline (MAb H9724), anti-OspA (MAbs H5332 en H3TS) en anti-OspB (MAb H6831). Vergelijking van genotypische eigenschappen vond plaats aan de hand van "random amplified polymorphic DNA" (RAPD) PCR "fingerprints". Voor bepaling van de infectiviteit werden drie weken oude Lewis/M ratten gebruikt. Een isolaat werd beschouwd als infectieus wanneer dertig dagen na inoculatie $B$. burgdorferi kon worden geïsoleerd uit de huid, de blaas + nieren, de hersenen of de milt. Bij geen van de vijf $B$. burgdorferi isolaten werden na veertig in-vitro passages veranderingen waargenomen in het eiwit profiel, de MAb reactiviteit of de PCR "fingerprint". De drie Nederlandse tekenisolaten, die aanvankelijk infectieus waren voor Lewis ratten, verloren daarentegen hun infectiviteit na veertig in-vitro passages. In tegenstelling tot berichten uit de literatuur werd geen verband aangetoond tussen het verlies van infectiviteit en verandering of verlies van buitenmembraan eiwitten. De phenotypische en genotypische stabiliteit van de onderzochte isolaten tijdens in-vitro passage is in overeenstemming met de ervaring dat EIA en Western immunoblot resultaten niet significant worden beïnvloed door de keuze van het $B$. burgdorferi isolaat.

In Hoofdstuk 3 worden de resultaten beschreven van een onderzoek naar de besmettingsgraad van I. ricinus met $B$. burgdorferi in Nederland. 
In de periode juni tot en met september 1989 werden in totaal 1838 teken verzameld op 20 lokaties in 10 provincies (in Groningen en Flevoland werden geen teken verzameld). De teken werden verzameld door middel van "flagging". Bij deze methode wordt een witte flanellen doek over lage vegetaties gehaald. Bermen, wandelpaden en parkeerterreinen in en rond bos-, duin- en heidegebieden, waar de mens risico loopt om geïnfesteerd te worden met teken, werden bemonsterd. Identificatie en selectie van de teken vonden macroscopisch plaats. Nimfen werden in groepen van 4 en volwassen teken werden individueel gehomogeniseerd en in BSKII kweekmedium met toevoeging van neomycine, sulfamethoxazole en trimethoprim onderzocht op de aanwezigheid van $B$. burgdorferi. Beweeglijke spirocheten, morfologisch lijkend op Borrelia, werden meestal voor het eerst gezien na 2 tot 3 weken incubatie. De extra winst aan positieve monsters bij doorkweken na de $6^{\mathrm{e}}$ incubatieweek was gering en bedroeg $1,3 \%$. Uit 75 van de 659 monsters werden spirocheten geïsoleerd. Bij 63 van de 75 isolaten was doorkweken mogelijk. Deze 63 isolaten toonden allen een positieve reactie met het serum van een patiënt met Lyme borreliose. Het minimaal geschatte infectiepercentage van nimfen bedroeg $2,4 \%$. Bij volwassen teken was de besmettingsgraad op het totale aantal $14,3 \%$. In elke provincie waar I. ricinus werd verzameld, kon $B$. burgdorferi in nimfen en/of volwassen teken worden aangetoond. In Sittard (Limburg), Den Burg (Texel) en Oldeberkoop (Friesland) was het minimale besmettings percentage van nimfen 8, 9 en 15. Op de resterende 17 lokaties varieerde dit percentage van 0 tot 4 . Wat de volwassen teken betreft: wordt Drenthe waar geen volwassen teken werden verzameld buiten beschouwing gelaten, dan varieerde het percentage van 0 in Zeeland en Gelderland tot 30 op Texel. De besmettingspercentages van $I$. ricinus met $B$. burgdorferi in Nederland komen overeen met die elders in West-Europa. Belangrijk bij vergelijking van percentages is de toegepaste methode. De sensitiviteit van detectiemethoden zoals IFA en PCR is 1,5 à 2 maal hoger dan die van de kweek. Het is derhalve aannemelijk dat het werkelijke besmettingspercentage van I. ricinus in Nederland hoger is dan de in deze studie gevonden percentages.

In Hoofdstuk 4 wordt de genotypische en phenotypische analyse beschreven van de $63 \mathrm{~B}$. burgdorferi stammen, geïsoleerd uit I. ricinus (Hoofdstuk 3), en drie humane huidisolaten, afkomstig van drie Nederlandse patiënten met Lyme borreliose. De 63 tekenisolaten waren afkomstig van 17 lokaties in Nederland. De referentiestammen waren B. burgdorferiB31 (genospecies: $B$. burgdorferi sensu stricto) en PKo (genospecies: $B$. burgdorferi groep VS461). De genotypering was gebaseerd op "restriction fragment length polymorphism" (RFLP). Ten behoeve van "Southern blotting" werd $B$. burgdorferi DNA gesplitst met behulp van de endonucleases Hindlll en EcoRV. De DNA fragmenten werden gehybridizeerd met 16S+23S RNA ( $\mathrm{rRNA}$ ) van Escherichia coli en met een $730 \mathrm{bp}$ fragment van het flagelline gen van $B$. burgdorferi B31. De phenotypering was gebaseerd op vergelijking van de "Coomassie-blue" eiwitprofielen in het 30-36 kDa (OspA en OspB) en het 20-25 kDa (OspC) gebied, en de reactiviteit met de MAbs H9724 (anti-flagelline), H9724 en H3TS (anti-OspA) en H6831 (anti-OspB). 
Alle drie de huidisolaten werden getypeerd als B. burgdorferigroep VS461. Deze bevinding ondersteunt de berichten dat dit genospecies met name wordt geïsoleerd bij huidafwijkingen. Van de 63 tekenisolaten werden 29 $(46 \%)$ getypeerd als $B$. burgdorferi sensu stricto, $2(3 \%)$ als $B$. burgdorferi groep VS461 en $19(30 \%)$ als $B$. garinii. Dertien van de 63 isolaten $(21 \%)$ had een rRNA gen restrictie patroon dat afwijkend was van de drie eerder beschreven genospecies. Twaalf van deze 13 afwijkende isolaten vertoonden een uniform rRNA gen restrictie patroon. Deze groep wordt hierna aangeduid als $B$. burgdorferi groep M19. Het rRNA gen restrictie patroon van $B$. burgdorferi groep $M 19$ isolaten lijkt op dat van $B$. garinii. De rechtvaardiging voor de afsplitsing van deze groep van $B$. garinii werd ondersteund door hybridizatie met de flagelline probe, een geconserveerd deel van het genoom dat codeert voor het flagelline eiwit en meer dan 250 kbp verwijderd ligt van het rRNA gen cluster. Een van de 63 isolaten had een rRNA restrictie patroon, afwijkend van alle andere isolaten. De genotypische classificatie van de 66 Nederlandse $B$. burgdorferi isolaten correspondeerde maar gedeeltelijk met de classificatie op basis van eiwitprofielen en MAb reactiviteit. Met name kon met deze methoden geen onderscheid worden gemaakt tussen $B$. garinii en groep M19 isolaten. Het voorkomen van $B$. burgdorferi sensu stricto, $B$. garinii en B. burgdorferi groep VS461 in I. ricinus in Nederland correspondeert met het voorkomen van deze drie genospecies in andere Europese landen. De bevinding dat B. burgdorferi sensu lato waarschijnlijk meer dan drie genospecies bevat, is belangrijk in het licht van recente berichten dat de verschillende genospecies van $B$. burgdorferi zijn geassocieerd met verschillende klinische beelden en dat met name $B$. garinii wordt geassocieerd met extracutane manifestaties van Lyme borreliose. Meer onderzoek is nodig om de status van de M19 groep vast te stellen.

In Hoofdstuk 5 worden negen serologische testen voor de diagnostiek van Lyme borreliose vergeleken met betrekking tot sensitiviteit, specificiteit, intra- en inter-test precisie en kosten. Tweehonderd klinisch goed gedefinieerde serummonsters werden onderverdeeld in zes categorieën op basis van herkomst van patiënten met vroege Lyme borreliose $(n=13)$, late Lyme borreliose $(n=21)$, asymptomatische Lyme borreliose $(n=36)$, rheumafactor (RF) positieve rheumatoïde arthritis $(n=15)$, syphilis $(n=31)$ en gezonde controle personen $(n=84)$. Alle patiënten met vroege Lyme borreliose hadden een erythema migrans. De patiënten met late Lyme borreliose hadden een erythema migrans in de anamnese maar in aansluiting hierop langdurige arthralgieën (4), arthritis (15), of acrodermatitis chronica atrophicans (2) ontwikkeld. De asymptomatische Lyme borreliose groep bestond uit Zwitserse "cross-country runners", een "high-risk" groep voor Lyme borreliose vanwege de regelmatige blootstelling aan tekebeten. Deze "cross-country runners" waren asymptomatisch zonder anamnese passend bij Lyme borreliose. De sera van deze personen waren eerder positief bevonden in een Zwitserse "whole-cell" sonicaat IgG EIA voor Lyme borreliose. De volgende testen voor het aantonen van antilichamen tegen $B$. burgdorferi werden vergeleken: twee zelf opgezette IFAs en twee zelf opgezette EIAs, een 
commercieel verkrijgbare haemagglutinatietest (Diagast), en vier commercieel verkrijgbare EIAs (Dako, Diamedix, Whittaker en Diagast). Als antigeen voor de vier zelf opgezette IgG testen dienden intacte cellen (voor de IFAs) of een "whole-cell" sonicaat (voor de EIAs) van B. burgdorferi B31. Eén zelf opgezette IFA en EIA werd uitgevoerd zonder adsorptie van de sera en in de andere werden de sera vooraf geadsorbeerd aan een sonicaat van Treponema phagedenis met het doel kruisreactiviteit te reduceren. De Diagast haemagglutinatietest maakt gebruik van schape-erytrocyten die dienen als drager van flagellaire en buitenmembraan antigenen van $B$. burgdorferi B31. Met deze test worden IgG en IgM aangetoond. De vier commercieel verkrijgbare EIAs verschillen onder andere met betrekking tot de toegepaste $B$. burgdorferi stam, de aard van het antigeen preparaat, het toegepaste $\lg$ conjugaat ( $\lg \mathrm{G}$ of $\lg \mathrm{G} / \mathrm{lgM}$ ) en het al dan niet adsorberen van de sera. De Dako EIA, een IgG test waarin de sera niet worden geadsorbeerd, maakt gebruik van gezuiverde natieve flagellen van een humaan erythema migrans isolaat. In de Diamedix EIA, een IgG/lgM test op basis van flagelline verrijkt antigeen van de B31 stam, worden de sera wel geadsorbeerd. De Whittaker EIA, eveneens een IgG/lgM test, maakt gebruik van een "wholecell" sonicaat van de B31 stam. De sera worden bij deze test niet geadsorbeerd. Bij de Diagast ElA wordt in geadsorbeerde sera IgG aangetoond met behulp van een $B$. burgdorferi B31 preparaat bestaande uit $41 \mathrm{kDa}$ eiwitten, OspA en OspB eiwitten en een $100 \mathrm{kDa}$ eiwit. In het vroege stadium van Lyme borreliose had de Dako EIA de hoogste sensitiviteit (62\%) en de Diagast haemagglutinatietest de laagste sensitiviteit (8\%). De sensitiviteit van de overige testen varieerde van $54 \%$ voor de Diamedix EIA en de zelf opgezette EIA met adsorptie tot $31 \%$ voor de beide zelf opgezette IFAs en de Whittaker EIA. In het late stadium van Lyme borreliose hadden de Diagast haemagglutinatietest en de Whittaker EIA de laagste sensitiviteit (respectievelijk $62 \%$ en $71 \%$ ). Alle overige testen hadden een sensitiviteit van $86 \%$. In de asymptomatische Lyme borreliose groep varieerde het aantal positieve monsters van 36/36 in de beide zelf opgezette EIAs en de zelf opgezette IFA met adsorptie tot 10/36 in de Diagast haemagglutinatietest. Met betrekking tot RF positieve sera en gezonde controles hadden alle testen een specificiteit van respectievelijk $\geq 93 \%$ en $\geq 95 \%$. Bij patiënten met syphilis was de specificiteit van de zelf opgezette ElA zonder adsorptie (29\%) significant lager dan de overige 8 testen (68\% tot $100 \%)$ $(p<0,05)$.

De intra- en inter-test precisie van de ElAs varieerde van respectievelijk 86 tot $97 \%$ en van 77 tot $89 \%$. Wanneer behalve de sensitiviteit en de specificiteit ook de intra- en inter-test variatie, het gemak van uitvoering en de kosten per bepaling in beschouwing worden genomen, dan zijn de Dako EIA en de Diamedix EIA een goed alternatief voor zelf opgezette testen. Vanwege de lage sensitiviteit wordt het gebruik van de Diagast haemagglutinatietest voor de diagnostiek van Lyme borreliose afgeraden.

In Hoofdstuk $\mathbf{6}$ wordt de waarde van Western immunoblot als specifieke confirmatietest voor Lyme borreliose onderzocht. Tweehonderd negen klinisch goed gedefinieerde sera werden onderverdeeld in vier categorieën op basis van herkomst van patiënten met vroege Lyme borreliose $(n=31)$, late Lyme borre- 
liose $(n=48)$, patiënten met aandoeningen die voorkomen in de klinische differentiaal diagnose van Lyme borreliose $(n=86)$ en gezonde personen $(n=44)$. In de patiënten controle groep hadden 21 patiënten RF positieve rheumatoïde arthritis, 18 spondylitis ankylopoetica, 9 arthritis psoriatica, 4 reactieve arthritis, 5 systemische lupus erythematosus, 9 arthritis e.c.i. en 20 syphilis. Van alle 209 sera was het EIA resultaat bekend. De IgG Western immunoblot was evenals de eerder geteste IgG EIA gebaseerd op een "whole-cell" sonicaat van $B$. burgdorferi B31. De Western immunoblot werd geëvalueerd met behulp van logistische regressie analyse waarbij $\mathrm{kDa}$ ranges in plaats van afzonderlijke kDa banden dienden als de onafhankelijke variabelen. Bij patiënten met Lyme borreliose was er weliswaar geen significant verschil tussen het aantal positieven in de Western blot en in de EIA (50/79 versus 55/79), maar de correlatie tussen Western immunoblot en ElA was slechts 0,41 . Bij patiënten die regelmatig voorkomen in de klinische differentiaal diagnose van Lyme borreliose en bij gezonde personen was het percentage vals-positieven in de Western blot significant lager dan in de EIA (10\% versus $43 \%)$. Deze reductie in het aantal vals-positieven werd niet significant beïnvloed door toepassing van verschillende regressiemodellen waarbij het aantal banden, het type banden, of de intensiteit van de banden werd benadrukt. Hoewel het aantal vals-positieven in de Western blot significant lager was dan in de EIA werden in de Western blot toch 11 van de 86 patiënten (13\%), die regelmatig voorkomen in de differentiaal diagnose van Lyme borreliose, positief bevonden. De conclusie van dit onderzoek is dat Western immunoblot niet kan worden beschouwd als een specifieke confirmatie test voor Lyme borreliose. Bij de keuze van Western immunoblot als alternatief voor EIA in het "routine" diagnostisch laboratorium moet worden bedacht dat sommige commercieel verkrijgbare EIAs een specificiteit hebben die vergelijkbaar is met die van Western blot.

In Hoofdstuk 7 wordt het voorkomen van symptomatische en asymptomatische Lyme borreliose in een "high-risk" groep en in de algemene populatie in Nederland onderzocht.

Bij 440 jachthondenbezitters, aangesloten bij de Nederlandse Jagersvereniging, werden bloedmonsters afgenomen. De jachthondenbezitters waren afkomstig uit alle delen van het land. Deelnemers aan het onderzoek kregen foto's van erythema migrans afwijkingen te zien en er werd aan hen gevraagd een enquêteformulier in te vullen. In de enquête werden vragen gesteld over de expositie aan teken en over mogelijk met Lyme borreliose verband houdende afwijkingen op het moment van bloedafneming of in het verleden. Tien bloedbanken van het Rode Kruis stelden in totaal 1052 donorsera voor het onderzoek ter beschikking. Het aantal bloeddonors was, per leeftijdscategorie en geslacht, minimaal 2 maal zo groot als het aantal jachthondenbezitters dat op basis van postcode aan elke bloedbank werd toegewezen. Het voorkomen van antilichamen tegen $B$. burgdorferi werd bepaald met de in Hoofdstuk 5 beschreven zelf opgezette IgG EIA op basis van een "whole-cell" sonicaat van $B$. burgdorferi $\mathrm{B} 31$. Bij jachthondenbezitters kwamen antilichamen tegen $B$. burgdorferi $(15 \%)$ significant vaker voor dan bij bloeddonors $(9 \%)(p=0,0002)$. Zowel bij jachthondenbezitters als bloeddonors nam het aantal seropositieven toe met de leeftijd: van 3\% (bloeddonors) en $0 \%$ (jachthondenbezitters) in de 
groep $<20$ jaar tot $12 \%$ respectievelijk $27 \%$ bij deelnemers ouder dan 59 jaar. Er was geen verschil in seropositiviteit tussen mannen en vrouwen. In tegenstelling tot wat bij jachthondenbezitters het geval was, varieerde bij de bloeddonors de seroprevalentie per regio aanzienlijk (van $2 \%$ in de regio Groningen tot $17 \%$ in de regio Leiden). Slechts $3 \%$ van de jachthondenbezitters gaf aan klinische verschijnselen te hebben (gehad) welke zeer waarschijnlijk een gevolg waren van een infectie met $B$. burgdorferi. Van de 68 seropositieve jachthondenbezitters hadden 64 (94\%) geen symptomen passend bij Lyme borreliose. De conclusie van dit onderzoek is dat asymptomatische (seropositieve) Lyme borreliose in Nederland frequent voorkomt bij personen met een vergrote kans op tekebeten en dat er in de algemene populatie een aanzienlijke variatie bestaat in het voorkomen van $\lg G$ antilichamen tegen $B$. burgdorferi. Het is derhalve zinloos om het voorkomen van antilichamen tegen $B$. burgdorferite laten bepalen wanneer klinisch geen aanwijzingen bestaan voor Lyme borreliose. 


\section{DANKWOORD}

Deze dissertatie is tot stand gekomen dankzij de aandacht, ondersteuning, medewerking en praktische vaardigheden van een groot aantal personen. Allereerst wil ik mijn promotor Prof.dr. C.P.A. van Boven bedanken dat hij mij de mogelijkheid heeft gegeven dit promotieonderzoek te starten. In het bijzonder wil ik mijn co-promotor Ton van den Bogaard bedanken. Beste Ton, jouw enthousiasme, jouw stimulerende houding wanneer ik het niet meer zag zitten, jouw goede en waardevolle suggesties en niet in de laatste plaats jouw logistieke creativiteit bij het verzamelen van de teken en de sera hebben uiteindelijk geresulteerd in het tot stand komen van dit proefschrift. Mijn andere promotor, Prof.dr. J.A.A. Hoogkamp-Korstanje, wil ik bedanken voor de kritische suggesties vooral in deze laatste fase.

Jacqueline Maes, beste Jacqueline, ik bedank je voor de fijne samenwerking en voor het vertroetelen van de Borrelia stammen. Dankzij jouw zorg en toewijding was het steeds mogelijk te beschikken over voldoende hoeveelheden antigeen.

Marie-Jose Keulers, beste Marie-Jose, ik ben je dankbaar voor de accuratesse waarmee je de duizenden EIA's hebt uitgevoerd.

Ellen Corsius, beste Ellen, bedankt voor het vele geduld waarmee je donkerveld-microscopisch op zoek was naar beweeglijke spirocheten.

Lieve Lemaître, beste Lieve, zonder jouw hulp waren de immunoblots niet op tijd afgekomen. Bedankt!

Jettie Tuin, beste Jettie, jou wil ik bedanken voor de zorgvuldigheid waarmee je de loopafstanden van de immunoblot bandjes hebt bepaald.

Rob de Boer, beste Rob, jij hebt een belangrijke bijdrage geleverd aan hoofdstuk 4. Veel dank en waardering daarvoor.

Ineke Blaauw bedank ik voor het ter beschikking stellen van de waardevolle sera van patiënten met Lyme borreliose.

Martin Luppes, beste Martin, ik ben je dankbaar voor het menig uurtje dat je in je vrije tijd hebt besteed aan de statistische evaluatie van de resultaten.

Jacques Meis, beste Jacques, jij hebt mij "gedwongen" een "dead-line" te stellen voor de afronding van dit proefschrift. Veel dank daarvoor.

Peter Donnelly, beste Peter, bedankt voor je kritische opmerkingen en je pogingen mijn Engels te verbeteren. 
Ilona Heynen, beste llona, bedankt voor de avonden die je in de lay-out van dit boekje hebt gestoken. Door jouw hulp ziet het er zo mooi uit.

Caty en Michel Wijn bedank ik voor de vakkundige wijze waarop zij aan dit proefschrift vorm hebben gegeven.

Tevens wil ik allen, die niet met name vermeld zijn, maar die wel hebben bijgedragen aan het tot stand komen van deze dissertatie, van harte bedanken.

Mijn familie en vrienden, bedankt voor de interesse, steun en afleiding.

Lieve Jan, zonder jouw geduld, begrip, zorg en liefde, had ik deze klus nooit kunnen klaren. 


\section{CURRICULUM VITAE}

De auteur van dit proefschrift werd geboren op 21 september 1950 te WehrSelfkant, Duitsland. Na het behalen van het diploma MULO-A werd van 1967 tot 1970 de hogere beroepsopleiding tot klinisch chemisch analiste gevolgd aan de Zuidlimburgse Laboratoriumschool Sittard, te Sittard. In de daarop volgende 2 jaar werkte zij als analiste, aanvankelijk in het klinisch chemisch laboratorium van het ziekenhuis De Goddelijke Voorzienigheid te Sittard en later in het isotopen laboratorium van het Institut für Medizin, Kernforschungsanlage te Jülich, Duitsland. In 1974 werd het diploma behaald aan het Köln-Kolleg, städtisches Institut zur Erlangung der Hochschulreife te Keulen. In de periode 1974 tot 1980 was zij werkzaam als analiste in het Maasland ziekenhuis te Sittard, aanvankelijk in het klinisch chemisch laboratorium en later als leidinggevende analiste van het laboratorium voor de bloedtransfusiedienst.

In 1980 werd begonnen met de studie geneeskunde aan de Rijksuniversiteit Limburg te Maastricht. Op 20 november 1986 werd de artsenbul cum laude uitgereikt. In december van hetzelfde jaar begon zij met de opleiding tot medisch microbioloog in het Academisch Ziekenhuis Maastricht (opleider: Prof.dr. C.P.A. van Boven). Na de inschrijving in het Nederlands Specialisten Register op 1 december 1990 was zij 2,5 jaar als medisch microbioloog verbonden aan het Maaslandziekenhuis te Sittard.

Sinds 1 juni 1993 is zij - binnen de Maatschap Medische Microbiologie en Medische Immunologie - als medisch microbioloog verbonden aan het ziekenhuis Rijnstate te Arnhem en aan het ziekenhuis Gelderse Vallei gevestigd te Bennekom, Ede en Wageningen. 
